ROBERTO MITSUAKE HIRAYAMA

\title{
FRAMEWORK PARA TESTES E AVALIAÇÃO DE SINCRONISMO PARA APLICAÇÕES DE TV DIGITAL MÓVEL
}

Dissertação apresentada no

Departamento de Engenharia de Computação e Sistemas Digitais da Escola Politécnica da Universidade de São Paulo como um dos pré-requisitos necessários para a obtenção do título de Mestre em Engenharia

São Paulo

2006 
ROBERTO MITSUAKE HIRAYAMA

\section{FRAMEWORK PARA TESTES E AVALIAÇÃO DE SINCRONISMO PARA APLICAÇÕES DE TV DIGITAL MÓVEL}

Dissertação apresentada no

Departamento de Engenharia de Computação e Sistemas Digitais da Escola Politécnica da Universidade de São Paulo como um dos pré-requisitos necessários para a obtenção do título de Mestre em Engenharia

Orientadora:

Profa. Dra. Regina Melo Silveira

São Paulo

2006 
AUTORIZO A REPRODUÇÃO E DIVULGAÇÃO TOTAL OU PARCIAL DESTE TRABALHO, POR QUALQUER MEIO CONVENCIONAL OU ELETRÔNICO, PARA FINS DE ESTUDO E PESQUISA, DESDE QUE CITADA A FONTE.

Hirayama, Roberto Mitsuake

Framework para testes e avaliação do sincronismo para aplicações de TV digital móvel / R.M. Hirayama. -- São Paulo, 2006. $174 \mathrm{p}$.

Dissertação (Mestrado) - Escola Politécnica da Universidade de São Paulo. Departamento de Engenharia de Computação e Sistemas Digitais.

1.Televisão (Engenharia Elétrica) - Distribuição 2.Comunicacoes digitais 3.Redes de computadores 4.Simulação I.Universidade de São Paulo. Escola Politécnica. Departamento de Engenharia de Computação e Sistemas Digitais Il.t. 


\section{FOLHA DE APROVAÇÃO}

ROBERTO MITSUAKE HIRAYAMA

FRAMEWORK PARA TESTES E AVALIAÇÃO DE SINCRONISMO PARA APLICAÇÕES DE TV DIGITAL MÓVEL

Dissertação apresentada no Departamento de Engenharia de Computação e Sistemas Digitais da Escola Politécnica da Universidade de São Paulo para a obtenção do título de Mestre em Engenharia.

Aprovado em:

Banca Examinadora

Prof. Dr.

Instituição: Assinatura:

Prof. Dr.

Instituição:

Assinatura:

Prof. Dr.

Instituição:

Assinatura:

Prof. Dr.

Instituição:

Assinatura:

Prof. Dr.

Instituição: Assinatura: 
À Lorena, esposa e companheira de todas as horas,

à minha filha querida Luiza Harumi, e em memória de minha adorada mãe Jani e de meu filho Cícero Akira. 


\section{AGRADECIMENTOS}

À minha estimada orientadora, Profa. Dra. Regina Melo Silveira, pelo aconselhamento, amizade e paciência.

À minha esposa amada, Lorena Sales dos Santos, pelo apoio incondicional durante todo o período dessa longa caminhada e pela revisão do texto final desta dissertação.

À minha querida filha, Luiza Harumi, pela constante inspiração de seu sorriso, fundamental para que a tranqüilidade não faltasse nos momentos decisivos para a conclusão desta dissertação.

Aos meus prezados colegas do Laboratório de Arquitetura e Redes de Computadores (LARC), em especial Raoni Kulesza e Hugo Estigarribia, pela amizade e auxílio inestimáveis.

Aos meus familiares e amigos que sempre estiveram ao meu lado e em meu coração. 


\section{SUMÁRIO}

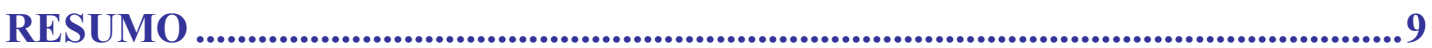

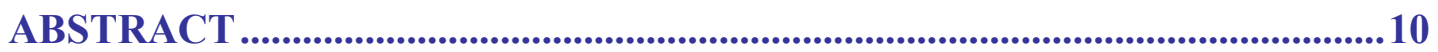

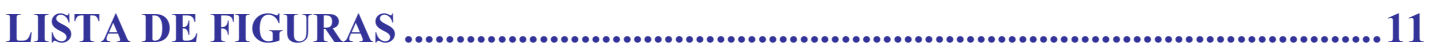

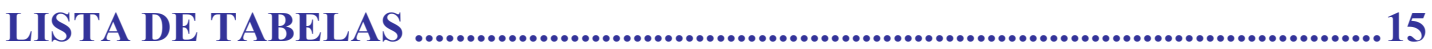

LISTA DE ABREVIATURAS ............................................................................16

1 INTRODUÇÃO ........................................................................................................ 19

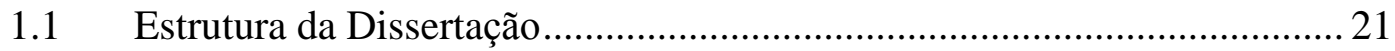

2 CONCEITOS BÁSICOS DA RADIODIFUSÃO DE SINAIS DE TV

DIGITAL PARA RECEPÇÃO MÓVEL ...............................................................22

2.1 Aspectos Gerais da Transmissão de Sinais de TV Digital........................ 22

2.2 Introdução à Infra-estrutura para Radiodifusão de TV Digital para

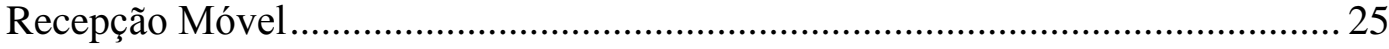

2.2.1 Modulação na TV Digital Móvel ...................................................... 25

2.2.2 Redes de distribuição de conteúdo na TV Digital Móvel ................... 28

2.3 Desafios da Radiodifusão de TV Digital para Recepção Móvel................. 31

3 MULTIPLEXAÇÃO NA INFRA-ESTRUTURA DE TV DIGITAL..........34

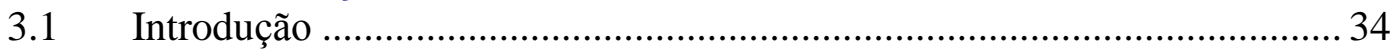

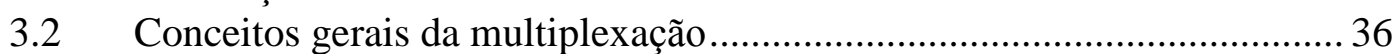

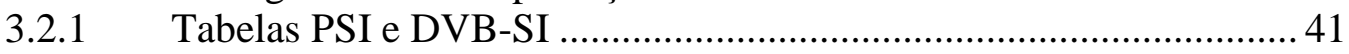

3.3 Mecanismos de multiplexação padronizados pelo MPEG2 ...................... 48

3.3.1 MPEG2 Transport Stream (MPEG2 TS) ...................................... 49

3.3.2 MPEG2 Program Stream (MPEG2 PS) ......................................... 52

3.3.3 Utilização do MPEG2 TS e do MPEG2 PS ........................................ 56

4 MECANISMOS DE SINCRONIZAÇÃO DO MPEG2 SYSTEM .............58

4.1 Modelo de Temporização do MPEG2 System .......................................... 59

4.2 Sincronização no Receptor de acordo com o MPEG2 System ....................67 67

4.3 Algoritmos de Ressincronização de Mídias ............................................... 71

4.3.1 Algoritmos de ressincronização baseados no recálculo do PCR e na compensação de variações de atraso ................................................................... 72

4.3.2 Algoritmo de Correção da Periodicidade das Amostras do Relógio do

Emissor 73

4.3.3 Algoritmo de Reposicionamento de pacotes com Escalonamento da

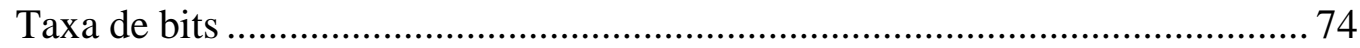

5 PROPOSTA DO FRAMEWORK PARA TESTES E AVALIAÇÃO DO

SINCRONISMO........................................................................................................ 76

5.1 Proposta de Ressincronização de Mídias .................................................... 76 
Sumário

5.2 Framework para Testes e Avaliação do Sincronismo 79

6 ESPECIFICAÇÃO DOS MÓDULOS DO FRAMEWORK PARA TESTES

E AVALIAÇÃO DO SINCRONISMO ....................................................................85

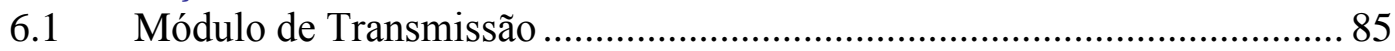

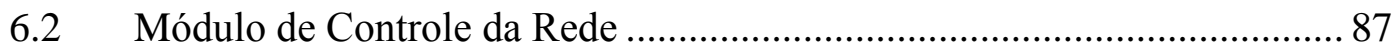

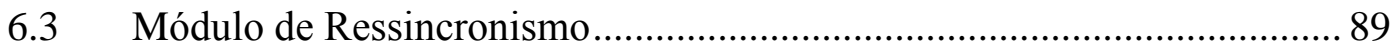

6.3.1 Módulo de inserção de pacotes nulos ............................................ 91

6.3.2 Módulo de reposicionamento dos pacotes contendo amostras do PCR 97

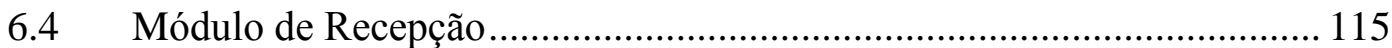

6.5 Módulo de Avaliação da Qualidade de Vídeo ......................................... 117

6.6 Módulo de Monitoração das Características das Amostras do PCR........ 121

7 CENÁRIOS DE TESTE E RESULTADOS EXPERIMENTAIS............... 123

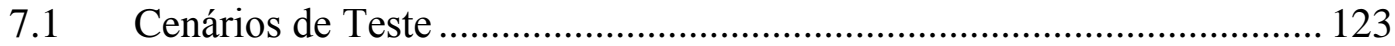

7.1.1 Cenário 1: Influência dos parâmetros de QoS na qualidade objetiva do

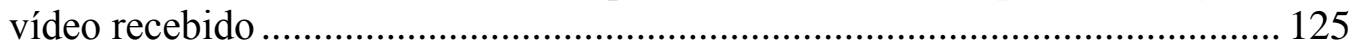

7.1.2 Cenário 2: Avaliação isolada do método de inserção de pacotes nulos 127

7.1.3 Cenário 3: Avaliação do módulo de ressincronismo operando na inserção de pacotes nulos e no descarte de pacotes dos quadros B ................. 128

7.1.4 Cenário 4: Avaliação do ressincronismo operando na inserção de pacotes nulos e na requantização de slices do vídeo....................................... 129

7.2 Resultados Experimentais .................................................................... 131

7.2.1 Aspectos do vídeo e da metodologia de testes ............................... 131

7.2.2 Cenário 1: Influência dos parâmetros de QoS na qualidade objetiva do

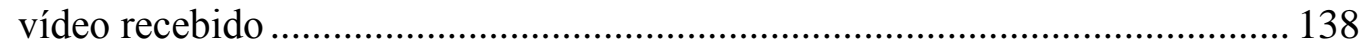

7.2.3 Cenário 2: Avaliação do método de inserção de pacotes nulos isoladamente

7.2.4 Cenário 3: Avaliação do ressincronismo implementado por meio dos métodos de inserção de pacotes nulos e de descarte de pacotes dos quadros B 150

7.2.5 Cenário 4: Avaliação do ressincronismo implementado por meio dos métodos de inserção de pacotes nulos e de requantização de slices do vídeo

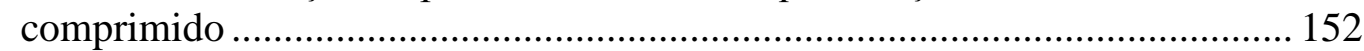

7.3 Análise dos Resultados Experimentais .............................................. 154

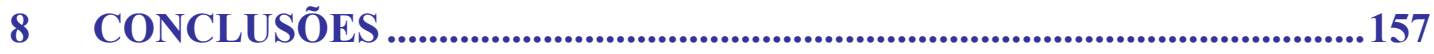

REFERÊNCIAS BIBLIOGRÁFICAS .................................................................161

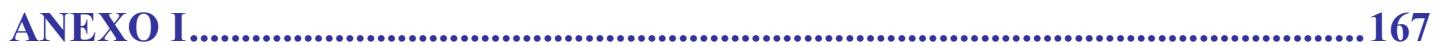




\section{RESUMO}

HIRAYAMA, R. M. Framework para testes e avaliação do sincronismo para aplicações de TV digital móvel. 2006. 174 f. Dissertação (Mestrado) - Escola Politécnica, Universidade de São Paulo, São Paulo, 2006.

No transporte de vídeo e áudio para aplicações de TV digital com recepção em terminais móveis podem ser utilizadas redes de distribuição de conteúdo baseadas em pacotes. Essas redes tornam o transporte dos sinais mais flexível. Entretanto, podem adicionar atrasos e variações de atraso, prejudicando o sincronismo dos fluxos de informação e, conseqüentemente, a apresentação das mídias. Nesta dissertação foi proposto um framework para avaliação e testes de sincronismo, desenvolvido para estudar a influência das perturbações causadas por redes de dados ou por remultiplexações no sincronismo de programas MPEG2. O framework possibilita o controle dos parâmetros de QoS da rede de distribuição utilizada para transmitir pacotes de um fluxo de transporte (MPEG2 Transport Stream) e permite avaliar a influência desses parâmetros no sincronismo do fluxo. Adicionalmente, foram implementados mecanismos de ressincronização do fluxo de transporte no framework, de forma a minimizar os efeitos dessas perturbações na rede. Verificouse que os métodos implementados reduzem os efeitos de variações de atraso da rede e ressincronizam o fluxo de transporte transmitido, de forma que a variação de atraso nas amostras da referência de tempo do fluxo (Program Clock Reference - PCR) volta aos níveis anteriores (sem aplicação de variação de atraso na rede).

Palavras-chave: Ressincronização de fluxos de transporte MPEG2. Recepção em terminais móveis. Qualidade de Serviço. TV Digital. 


\begin{abstract}
HIRAYAMA, R. M. Framework for tests and evaluation of the synchronism in digital television with mobile reception. 2006. 174 f. Dissertation (Master) Escola Politécnica, Universidade de São Paulo, São Paulo, 2006.

Content distribution packet networks can be used in video and audio transport for TV applications with reception in mobile terminals. These networks make signal transport more flexible. Nevertheless, they may add delay and jitter, damaging the synchronism of the information streams and, consequently, the media presentation. In this dissertation, a framework was proposed for synchronism test and evaluation. It was developed to study the influence of disturbances caused by data networks or remultiplexations in the synchronism of MPEG2 programs. The framework enables the control of QoS parameters of the distribution network used to transmit packets from a MPEG2 transport stream and allows the evaluation of the influence of these parameters in the synchronism of the streams. Furthermore, transport stream resynchronization mechanisms were implemented in the framework, minimizing the effects of these disturbances in the network. It was observed that the methods implemented reduce the effects of jitter in the network and resynchronize the transport stream transmitted, in a way that the jitter in the time reference samples (Program Clock Reference - PCR) of the stream returns to previous levels (without applying jitter in the network).
\end{abstract}

Keywords: Resynchronization of MPEG2 Transport Streams. Reception in mobile terminals. Quality of Service. Digital TV. 


\section{LISTA DE FIGURAS}

Figura 2.1 - Redes para transmissão de TV digital terrestre.

Figura 3.1 - Diagrama Esquemático da Multiplexação e Demultiplexação na TV Digital.

Figura 3.2 - Multiplexação no Fluxo de Programa e de Transporte (ISO 13818-1, 1994).

Figura 3.3 - Fluxo de pacotes TS exemplificando a multiplexação de informações. 40

Figura 3.4 - Estrutura multi-fluxos e multi-programas dos Fluxos de Transporte (TS).

Figura 3.5 - Esquema de consulta das tabelas PAT e PMT

Figura 3.6 - Pacote TS e seus campos.

Figura 4.1 - Modelo de temporização para atraso fim a fim constante (ISO 13818-1, 1994). 60

Figura 4.2 - Estrutura do campo de adaptação contendo uma amostra de PCR 63

Figura 4.3 - Diagrama de Blocos das principais atividades da URD (ISO 13818-1, 1994).

Figura 4.4 - Diagrama de blocos do PLL.

Figura 4.5 - Diagrama que mostra a interação dos elementos do receptor para manter o sincronismo. 70

Figura 4.6 - Exemplo da transformação da taxa de bits. 75

Figura 5.1 - Influência das variações na distância entre amostras do PCR. 78

Figura 5.2 - Rede primária de testes. 80

Figura 6.1 - Interface de linha de comando do VLMS. 87

Figura 6.2 - Interface gráfica do NISTNet 2.0.12b executado na distribuição Slackware Linux 10.1 89

Figura 6.3 - Diagrama de blocos do sistema de ressincronização. 90

Figura 6.4 - Pseudo-código das funções de recepção (a) e transmissão (b) de pacotes TS. 
Figura 6.5 - Pseudo-código da função que procura uma amostra do PCR dentro de uma série de pacotes TS

Figura 6.6 - Pseudo-código da função de conversão da amostra do PCR para microssegundos.

Figura 6.7 - Pseudo-código da função de ajuste dos parâmetros de sincronismo do

Fluxo de Transporte.

Figura 6.8 - Pacote TS Nulo, em hexadecimal (a) e esquemático (b). 96

Figura 6.9 - Diagrama Esquemático do Módulo de Inserção de Pacotes Nulos. 97

Figura 6.10 - Pseudo-código da função que identifica o tipo de quadro. .99

Figura 6.11 - Pseudo-código que implementa e controla o descarte de pacotes TS de quadros B. 101

Figura 6.12 - Exemplo da codificação de um bloco de vídeo com o MPEG2 ........ 103

Figura 6.13 - Processo simplificado de codificação e decodificação no MPEG2... 104

Figura 6.14 - Diagrama de Blocos do Requantizador. 105

Figura 6.15 - Diagrama de Blocos do Método por Requantização.

Figura 6.16 - Pseudo-código do Demultiplexador (a) e do Multiplexador (b).

Figura 6.17 - Fator de compressão (a) e PSNR (b) em função da constante de multiplicação da matriz de quantização $(\mathrm{k})$.

Figura 6.18 - Variação de Atraso das amostras do PCR de acordo com o Modelo de Temporização do MPEG2.

Figura 6.19 - Função de controle da requantização

Figura 6.20 - Diagrama de Blocos do método por requantização dos slices do vídeo comprimido.

Figura 6.21 - Interface gráfica da área de configuração do VLC (a) e da área de exibição de vídeo do VLC (b).

Figura 6.22 - Interfaces dos programas utilizados no módulo de Avaliação da Qualidade do Vídeo, (a) VACUM, (b) XMuxer e (c) Mplayer.

Figura 7.1 - Diagrama de Blocos do Cenário 1.

Figura 7.2 - Diagrama de Blocos do Cenário 2. 
Figura 7.3 - Diagrama de Blocos do Cenário 3 129

Figura 7.4 - Diagrama de Blocos do Cenário 4

Figura 7.5 - Nível de atividade do vídeo utilizado nos testes

Figura 7.6 - Taxa de bits dos GOPs do vídeo utilizado nos testes.

Figura 7.7 - Taxa de bits para os quadros I, P e B do vídeo de testes. 134

Figura 7.8 - Variação da taxa de bits em quadros sucessivos do vídeo, (a) região com nível de atividade elevada e (b) região com nível de atividade baixa.

Figura 7.9 - Intervalos entre PCR consecutivos do fluxo de transporte utilizado nos testes.

Figura 7.10 - Variação do PSNR para todos os quadros do vídeo de testes

Figura 7.11 - Quadros do vídeo de trabalho em diversas situações de perda de pacotes, (a) $0 \%$, (b) $1 \%$, (c) $3 \%$, (d) $5 \%$, (e) $7 \%$ e (f) $10 \%$.

Figura 7.12 - Gráficos do PSNR em função de parâmetros de QoS, (a) perda de pacotes, (b) duplicação de pacotes, (c) variação de atraso e (d) atraso.

Figura 7.13 - Reordenamento de Pacotes, (a) tipo de quadro registrado, (b) posição relativa dos quadros, (c) Bytes Offset, e (d) Time Offset.

Figura 7.14 - Gráfico da variação de atraso das amostras do PCR (PCR Jitter) para a variação de atraso na rede de $5 \mathrm{~ms}$

Figura 7.15 - Gráfico da variação de atraso das amostras do PCR (pcr jitter) para a variação de atraso na rede de $5 \mathrm{~ms}$, com a atuação do módulo de ressincronismo implementando o algoritmo de inserção de pacotes nulos

Figura 7.16 - Gráfico do PSNR em função da variação de atraso para o cenário 2.149

Figura 7.17 - Gráfico da variação de atraso das amostras do PCR para a variação de atraso na rede de $5 \mathrm{~ms}$, com a atuação do módulo de ressincronismo implementando o algoritmo de descarte de pacotes de quadros $\mathrm{B}$.

Figura 7.18 - Gráfico do PSNR em função da variação de atraso para o Cenário 3.

Figura 7.19 - Gráfico da variação de atraso das amostras do PCR para a variação de atraso na rede de $5 \mathrm{~ms}$, com a atuação do módulo de ressincronismo implementando o algoritmo de requantização de slices. 
Figura 7.20 - Gráfico do PSNR em função da variação de atraso para o Cenário 4. 153 


\section{LISTA DE TABELAS}

Tabela 2.1 - Taxas de bits para dois esquemas de modulação do COFDM para canal

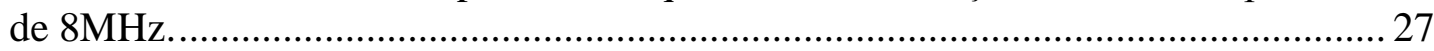

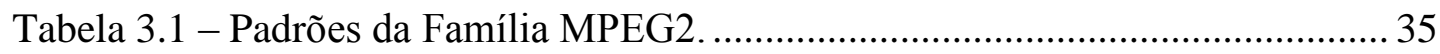

Tabela 3.2 - Comparação entre os fluxos de transporte (TS) e programa (PS)......... 39

Tabela 3.3 - Estrutura de uma seção da tabela PAT................................................. 43

Tabela 3.4 - Estrutura de uma seção da tabela PMT............................................... 43

Tabela 3.5 - Estrutura de uma seção da tabela CAT. .............................................. 44

Tabela 3.6 - Estrutura de uma seção de tabela Privada............................................ 45

Tabela 3.7 - Alocação de PID para tabelas de serviço (PSI e DVB-SI)..................... 48

Tabela 3.8 - Identificadores de categorias de conteúdo possíveis de serem

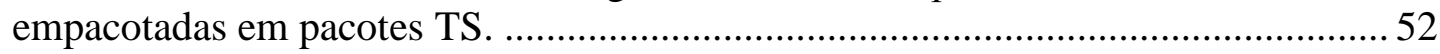

Tabela 3.9 - Start codes e stream ids do MPEG2 System. ..................................... 53

Tabela 7.1 - Principais objetivos e aspectos analisados para cada um dos cenários de teste.

Tabela 7.2 - Intervalos de variação para os parâmetros de QoS para atingir um MOS equivalente a 1 


\section{LISTA DE ABREVIATURAS}

\begin{tabular}{|c|c|}
\hline ATM & Asynchronous Transfer Mode \\
\hline ATSC & Advanced Television Systems Committee \\
\hline BAT & Bouquet Association Table \\
\hline CAT & Conditional Access Table \\
\hline COFDM & Coded Orthogonal Frequency Division Multiplexing \\
\hline $\mathrm{CPE}$ & Customer Premises Equipment \\
\hline $\mathrm{CRC}$ & Código de Redundância Cíclica \\
\hline DCT & Discrete Cosine Transform \\
\hline DIT & Discontinuity Information Table \\
\hline DTS & Decoding Time Stamp \\
\hline DVB-H & Digital Video Broadcasting - Handheld \\
\hline DVB-SI & Digital Video Broadcasting - Service Information \\
\hline DVB-T & Digital Video Broadcasting - Terrestrial \\
\hline EIT & Event Information Table \\
\hline ENM & Entitlement Management Messages \\
\hline ES & Elementary Stream \\
\hline ESCR & Elementary Stream Clock Reference \\
\hline FFT & Fast Fourier Transform \\
\hline FPB & Filtro Passa-Baixas \\
\hline GOP & Group of Picture \\
\hline HP & High Priority (modulação no DVB) \\
\hline IDCT & Inverse Discrete Cosine Transform \\
\hline IEC & International Electronics Commission \\
\hline IP & Internet Protocol \\
\hline ISDB-T & Integrated Services Digital Broadcasting - Terrestrial \\
\hline ISO & International Standardization Organization \\
\hline ITU-T & $\begin{array}{l}\text { International Telecommunications Union }- \text { Telecommunications } \\
\text { Standardization Sector }\end{array}$ \\
\hline LARC & Laboratório de Arquitetura e Redes de Computadores \\
\hline LP & Low Priority (modulação no DVB) \\
\hline
\end{tabular}




\begin{tabular}{|c|c|}
\hline $\mathrm{MFN}$ & Multiple Frequency Networks \\
\hline MP@ML & Main Profile at Main Level \\
\hline MPEG & Moving Pictures Expert Group \\
\hline MPEG2 TS & MPEG2 Transport Stream \\
\hline MSE & Mean Square Error \\
\hline MSSG & MPEG Software Solutions Group \\
\hline NIT & Network Information Table \\
\hline PAT & Program Allocation Table \\
\hline PCR & Program Clock Reference \\
\hline PCR & Program Clock Reference \\
\hline PDH & Plesiochronous Digital Hierarchy \\
\hline PES & Packetized Elementary Stream \\
\hline PID & Packet Identifier \\
\hline PLL & Phase Locked Loop \\
\hline PMT & Program Map Table \\
\hline PS & Program Stream \\
\hline PSI & Program Specific Information \\
\hline PSNR & Peak Signal to Noise Ratio \\
\hline PTS & Presentation Time Stamp \\
\hline QAM & Quadrature Amplitude Modulation \\
\hline QoS & Qualidade de Serviço \\
\hline QPSK & Quadrature Phase Shift Keying \\
\hline RF & Rádiofreqüência \\
\hline RLD & Run Level Decoding \\
\hline RLE & Run Level Encoding \\
\hline RMSE & Root Mean Square Error \\
\hline RST & Running Status Table \\
\hline SCR & System Clock Reference \\
\hline SDH & Synchronous Digital Hierarchy \\
\hline SDT & Service Description Table \\
\hline SDTV & Standard Definition Television \\
\hline SFN & Single Frequency Networks \\
\hline
\end{tabular}




\begin{tabular}{ll} 
SI & Service Information \\
SIT & Selection Information Table \\
ST & Stuffing Table \\
STB & Set-top Box \\
STC & System Time Clock \\
TCP & Transport Control Protocol \\
TDT & Time and Date Table \\
TM5 & MPEG2 Test Model 5 \\
TOT & Time Offset Table \\
TS & Transport Stream \\
TSDT & Transport Stream Description Table \\
TVD-T & TV Digital Terrestre Aberta \\
UDP & User Datagram Protocol \\
URD & Unidade Receptora e Decodificadora \\
VBR & Variable Bit Rate \\
VCO & Voltage Clock Oscillator \\
VLC & Variable Length Coding \\
VLD & Variable Length Decoding \\
VQM & Video Quality Metric \\
VSB & Vestigial Side Band \\
\hline
\end{tabular}




\section{INTRODUÇÃO}

No transporte de vídeo e áudio para aplicações de TV digital com recepção em terminais móveis podem ser utilizadas redes de distribuição de conteúdo baseadas em pacotes. Essas redes tornam o transporte dos sinais mais flexível, entretanto, podem adicionar atrasos e variações de atraso, prejudicando o sincronismo dos fluxos de informação e conseqüentemente a apresentação das mídias.

Esta dissertação, inserida no contexto dos projetos do Laboratório de Arquitetura e Redes de Computadores (LARC) da EPUSP, busca contribuir para o desenvolvimento de um sistema brasileiro de TV digital. Para isso, são analisados os mecanismos de sincronismo para aplicações de TV digital com recepção móvel, sendo proposto um framework para avaliar e testar as condições de sincronismo dessas aplicações. Além disso, alguns dos métodos de ressincronização existentes são integrados ao framework com o intuito de melhorar o desempenho da apresentação de mídias em terminais móveis de TV Digital.

A integração dos métodos de ressincronização ao framework tem o propósito de compensar os atrasos e a variação de atraso da rede de distribuição de conteúdo que, para essa dissertação, é considerada uma rede de pacotes.

Além da ressincronização na rede de distribuição de conteúdo, outro exemplo de necessidade de ressincronização ocorre na inserção de programação local de produtoras regionais ao sinal multiplexado e transmitido pelas grandes emissoras. Nessa inserção, que se mostra fundamental para promover uma saudável democratização da produção de conteúdo de televisão no Brasil, são inseridos atrasos e variação de atraso.

Os equipamentos utilizados para incluir ou excluir programas ${ }^{1}$ do sinal de TV digital são denominados remultiplexadores. Eles extraem os programas do sinal original, adicionam os novos programas e geram um novo sinal multiplexado. As manipulações e o processamento do sinal de TV digital efetuado pelos

\footnotetext{
${ }^{1}$ Programa para o comitê MPEG (Moving Pictures Expert Group) é o serviço ou canal simples de radiodifusão que possui uma base de tempo comum (ISO 13818-1, 1994). Portanto, numa programação real de $\mathrm{TV}$, com várias emissoras transmitindo, são disponibilizados diversos programas MPEG que, por sua vez, podem ser formados por vários fluxos de informação. No decorrer dessa dissertação, o conceito de programa será o definido pelo MPEG.
} 
Introdução

remultiplexadores inserem atrasos e variação de atraso. Esses elementos de rede necessitam, portanto, efetuar a ressincronização ${ }^{2}$ dos programas para a geração do novo sinal multiplexado contendo os programas inseridos e/ou retirados.

$\mathrm{Na}$ utilização de redes de transporte baseadas em pacotes para a distribuição de mídias às aplicações móveis de TV digital, atraso e variação de atraso também são inseridos $\mathrm{e}$, conseqüentemente, o sincronismo dos programas pode ficar comprometido.

Nesse cenário, é importante garantir que receptores possam ressincronizar seus programas. Por conseguinte, métodos que garantam o sincronismo são fundamentais para as aplicações de TV digital. Sendo necessário também que mecanismos para compensar tais fenômenos (ou seja, atrasos e variação de atraso) sejam especificados para as aplicações móveis de TV Digital. Esta dissertação propõe um framework que implementa métodos de ressincronização, de forma que eles possam ser utilizados para compensar distúrbios adicionados no transporte de mídias por meio de redes de pacotes em aplicações de TV digital com recepção móvel.

O framework para avaliação e testes de sincronismo tem como objetivo principal estudar a influência das perturbações causadas por redes de pacotes e remultiplexações no sincronismo de programas MPEG2. Nesse framework são inseridos atrasos e variações de atrasos aos pacotes de um fluxo de transporte (MPEG2 Transport Stream) e é avaliada a influência dessas perturbações na apresentação das mídias aos usuários e no sincronismo desse fluxo. Adicionalmente, o framework contém um módulo de ressincronização de mídias que minimiza as distorções no sincronismo causadas pelas perturbações inseridas previamente. O framework possibilita a especificação e a análise de algoritmos de ressincronização, agindo diretamente nos parâmetros relevantes para o sincronismo dos programas MPEG2.

\footnotetext{
${ }^{2}$ Ressincronização de programas, no âmbito dos remultiplexadores, consiste na especificação dos parâmetros de sincronismo do novo sinal multiplexado, de forma a garantir o sincronismo na exibição do programa no receptor.
} 
Introdução

\subsection{Estrutura da Dissertação}

Os próximos capítulos desta dissertação estão estruturados da seguinte forma:

- Capítulo 2: Apresenta conceitos sobre as aplicações de TV digital com recepção móvel e suas principais limitações;

- Capítulo 3: Descreve os procedimentos utilizados para multiplexar mídias para sua transmissão através da infra-estrutura da TV digital. São detalhadas a filosofia e a implementação de dois mecanismos de multiplexação bastante distintos: O Fluxo de Programa e o Fluxo de Transporte. Cada um deles tem aplicações bem definidas, entretanto, para o interesse desta dissertação o Fluxo de Transporte é o mais relevante. Esses mecanismos são muito importantes para a implementação de um padrão brasileiro de TV digital, sendo amplamente utilizados nos principais sistemas existentes - ISDB-T, DVB-T e ATSC;

- Capítulo 4: Apresenta os mecanismos básicos de sincronização, padronizados pelo MPEG2 System e amplamente utilizados em soluções para TV digital, tanto nos codificadores e multiplexadores como nas unidades receptora e decodificadora (URD). São descritos: o modelo de temporização especificado pelo padrão do MPEG2 System, a estrutura de um receptor genérico e como os mecanismos de sincronização estão inseridos entre os vários elementos que constituem o receptor. Também são descritos alguns algoritmos de ressincronização;

- Capítulo 5: Apresenta a proposta do framework para teste e avaliação de sincronismo em aplicações de TV Digital móvel;

- Capítulo 6: Especifica cada um dos módulos que constituem o framework para testes e avaliação do sincronismo proposto no capítulo 5;

- Capítulo 7: Apresenta os cenários de teste e discute os resultados experimentais obtidos;

- Capítulo 8: Apresenta as conclusões do trabalho;

- Referências Bibliográficas;

- Anexo I: Apresenta os códigos fonte das principais funções implementadas nos módulos do framework de testes e avaliação de sincronismo. 


\section{CONCEITOS BÁSICOS DA RADIODIFUSÃO DE SINAIS DE TV DIGITAL PARA RECEPÇÃO MÓVEL}

Neste capítulo serão descritos alguns aspectos da infra-estrutura necessária para a radiodifusão de sinais de TV digital destinada à recepção por terminais móveis em uma região metropolitana qualquer, por exemplo, a cidade de São Paulo. Serão abordados detalhes sobre a geração do conteúdo, o transporte desse conteúdo até as antenas de transmissão, a modulação ${ }^{3}$ do conteúdo em sinais de TV Digital e sua efetiva transmissão. Esses mecanismos podem ser adaptados para garantir o desempenho da transmissão e da recepção por um terminal móvel. Nesse contexto, serão apontados os problemas e as possíveis soluções para a transmissão e recepção móvel de sinais de TV Digital.

\subsection{Aspectos Gerais da Transmissão de Sinais de TV Digital}

A transmissão de sinais de TV Digital pode ser feita de diversas maneiras, por exemplo, através de um meio físico confinado (cabos coaxiais, fibra ótica, pares metálicos, etc.) ou por meio de radiofreqüências (radiodifusão ou transmissão via satélite). Neste capítulo serão apresentados apenas os aspectos relativos à radiodifusão, mais especificamente, a radiodifusão de sons e imagens para livre recepção por terminais dentro de uma área de cobertura, ou seja, TV Digital Terrestre Aberta (TVD-T).

Existem algumas alternativas para a implementação da TVD-T. Cada emissora, de uma determinada cidade, pode implementar seu próprio sistema de transmissão, ou podem ser criados um ou mais consórcios de emissoras para compartilhar os custos da digitalização. No segundo caso, deve ser constituída uma nova entidade designada operador de rede, que terá a responsabilidade de operar e manter a rede para a transmissão dos programas produzidos pelas emissoras que façam parte do consórcio ou que contratem seus serviços (produtoras independentes).

\footnotetext{
${ }^{3}$ Modulação é o processo utilizado para variar as características de um sinal portador, tipicamente sinusoidal, de forma a utilizá-lo para transportar informação.
} 
Conceitos básicos da radiodifusão de sinais de TV digital para recepção móvel

Em cada uma dessas alternativas, aspectos como a sintonia dos programas e o empacotamento de programação são diferentes. No primeiro caso, onde cada emissora implementa sua própria rede, a sintonia dos programas é feita primeiramente por meio da escolha da faixa de freqüências associada a emissora (canal de radiodifusão) e, em seguida, do fluxo de informação desejado entre os fluxos multiplexados no sinal transmitido. No segundo caso, podem ser definidos dois cenários: um único operador de rede, ou vários operadores de rede. Para um único operador de rede, a sintonia da faixa de freqüências perde a importância, pois todo o espectro de freqüências licenciado para as emissoras dentro da cidade atendida está disponível ao operador de rede. A sintonia de programas é feita por meio da escolha dos fluxos de informação multiplexados no sinal transmitido. Quando há vários operadores de rede, a escolha de um deles precede à do fluxo de informação, portanto deve ser dada a opção de sintonia da faixa de freqüências utilizada por um operador de rede específico. Cada terminal, seja fixo ou móvel, deve executar as operações descritas acima para sintonizar um programa.

Os elementos do sistema de transmissão para recepção fixa ou móvel são basicamente os mesmos: multiplexadores, moduladores, sistema irradiante, etc. Entretanto, como as condições de recepção são diferentes, devem ser configurados parâmetros de modulação diferentes. Em conseqüência, a topologia de uma rede com recepção fixa torna-se bastante diferente de uma rede com recepção fixa e móvel. O número de transmissores é maior para uma rede com ambos os modos de recepção. A razão para essas diferenças na topologia será esclarecida na seção 2.2.

Abordando especificamente a recepção móvel, observa-se que as condições de recepção em terminais móveis são mais complexas devido à sua natureza de construção e uso. Os terminais de recepção móvel de TV utilizam, em grande parte dos casos, antenas embutidas ${ }^{4}$ em sua carcaça, que apresentam características de recepção bastante diferentes das antenas externas ${ }^{5}$ utilizadas para a recepção fixa. $\mathrm{Ou}$ seja, esses terminais utilizam antenas com ganhos menores, que nem sempre contam com recursos como diversidade de recepção, antenas inteligentes, e outros. A

\footnotetext{
${ }^{4}$ Antenas embutidas são geralmente utilizadas no interior de uma residência, escritório ou qualquer construção, ou seja, podem ser consideradas também antenas internas.

${ }^{5}$ Antenas externas são aquelas que se situam no lado de fora de uma construção: no telhado, no topo de um prédio, etc. São geralmente maiores que as antenas internas.
} 
Conceitos básicos da radiodifusão de sinais de TV digital para recepção móvel

conseqüência do uso das antenas embutidas é a necessidade de níveis de relação sinal-ruído ${ }^{6}$ mais elevados. A mobilidade agrava ainda mais as condições de recepção por múltiplos percursos, pois, em movimento, os obstáculos entre o transmissor e o receptor mudam e assim as condições de recepção variam com o tempo. Além disso, o sinal recebido pelos terminais móveis pode ter a intensidade bastante reduzida, quando são utilizados dentro de alguma construção. Em conseqüência, alguns parâmetros da modulação devem ser adaptados. Por exemplo, os intervalos de guarda entre portadoras do esquema de modulação COFDM devem ser maiores. Por esses e outros motivos, a eficiência espectral ${ }^{7}$ para a transmissão dos sinais de TV Digital Móvel é menor e, conseqüentemente, a banda disponível por canal também o é.

Os principais padrões de TVD-T existentes, ATSC $^{8}$ (ATSC A/53C, 2004), DVB-T $^{9}$ (EM 300 744, 2004) e ISDB-T ${ }^{10}$ (ARIB STD B-31, 2002), apresentam filosofias diferentes para a recepção móvel. No ISDB-T, o canal de radiodifusão é dividido em 13 segmentos, dos quais alguns são reservados para recepção móvel. Os parâmetros de modulação dos segmentos reservados para a recepção móvel são especificados de forma a adequar o sinal transmitido às condições para recepção móvel. No DVB-T, algo semelhante pode ser feito, utilizando o modo hierárquico na transmissão. Nessa configuração, são estabelecidos dois modos de transmissão, em alta prioridade (HP, High Priority) e em baixa prioridade (LP, Low Priority). Cada um dos modos possui parâmetros de modulação diferentes, de forma a adequá-los aos terminais fixos (HP) ou móveis (LP). O ATSC possui um esquema de modulação com portadora única e, por isso, não podem ser configurados dois modos de transmissão para atender requisitos de recepção diferentes. Ou seja, o ATSC não implementa modulação hierárquica e segmentação, apesar de ser possível adaptar os parâmetros de sua modulação, visando atender às condições de recepção móvel ou fixa.

\footnotetext{
${ }^{6}$ Relação Sinal-Ruído (SNR) é a razão entre a potência do sinal e a potência do ruído no canal. É uma medida da influência do ruído na recepção do sinal em determinado ponto da área de cobertura ou para certa distância percorrida pelo sinal em um meio físico.

7 Eficiência Espectral é a medida do desempenho de métodos de codificação que representam a informação como variações em sinais analógicos. É dado em bits por segundo para cada $1 \mathrm{~Hz}$ de largura de banda.

${ }^{8}$ ATSC, Advanced Television Systems Comittee.

${ }^{9}$ DVB-T, Digital Video Broadcasting - Terrestrial.
} 
Conceitos básicos da radiodifusão de sinais de TV digital para recepção móvel

Nas seções a seguir, serão descritas a infra-estrutura típica para a implementação da radiodifusão de sinais de TV digital com recepção móvel em uma rede de freqüência única (SFN - Single Frequency Network) e as limitações dessa configuração. Além disso, serão introduzidas as principais questões que devem ser solucionadas para essa aplicação.

\subsection{Introdução à Infra-estrutura para Radiodifusão de TV Digital para Recepção Móvel}

A recepção móvel impõe algumas restrições que têm reflexos na infraestrutura para sua implementação. Nesta seção serão introduzidos alguns conceitos fundamentais para a transmissão de sinais que possam ser recebidos com qualidade por terminais móveis de TV Digital. Dentre os aspectos a serem discutidos estão: a influência da modulação na qualidade do vídeo recebido por um terminal móvel, os efeitos da modulação na cobertura de cada célula do sistema de TVD-T e as topologias de rede de distribuição de conteúdo para um sistema de TVD-T.

\subsubsection{Modulação na TV Digital Móvel}

Uma análise dos principais métodos de modulação para a TVD-T, COFDM ${ }^{11}$ (FARIA, 2000) e 8-VSB ${ }^{12}$ (SPARANO, 1997; CITTA; SGRIGNOLI, 1997), padrão europeu e americano, respectivamente, indica que a garantia de uma qualidade satisfatória do vídeo na recepção móvel depende, em grande medida, da modulação utilizada, devendo essa ser suficientemente robusta para minimizar os efeitos de ruídos $^{13}$, de distorções oriundas da recepção de sinais por múltiplos percursos, de atenuação, dentre outros (FERNÁNDEZ ET AL, 2000; BROOKS; MATTEI, 1999).

A modulação tem o objetivo principal de transportar os bits de informação por meio de um canal, utilizando uma portadora. Esse padrão de bits é representado

\footnotetext{
${ }^{10}$ ISDB-T, Integrated Services Digital Broadcasting - Terrestrial.

${ }^{11}$ COFDM, Coded Orthogonal Frequency Division Multiplexing.

12 8-VSB, 8-Vestigial Side Band.

${ }^{13}$ Ruídos são flutuações ou adições de fatores externos ao fluxo de informação (sinal) recebido no receptor.
} 
Conceitos básicos da radiodifusão de sinais de TV digital para recepção móvel

por símbolos ${ }^{14}$ e cada método de modulação procura otimizar a relação entre bits e símbolos, atingindo a eficiência desejada em termos de largura de banda do canal, ou seja, obtendo a eficiência espectral desejada (HAYKIN, 1994).

No caso da TV digital, os canais são de 6,7 ou $8 \mathrm{MHz}$ e deve-se modular vídeo, áudio e dados para a transmissão nesses canais. Nos dois principais esquemas de modulação utilizados pela TV digital, COFDM (FARIA, 2000) e 8-VSB (SPARANO, 1997; CITTA; SGRIGNOLI, 1997), podem ser especificados parâmetros de acordo com o ambiente nos quais os sinais de TV digital são transmitidos. Por exemplo, tanto para o COFDM quanto para o 8-VSB podem ser utilizadas as modulações QPSK $^{15}, 16 \mathrm{QAM}^{16}$ e $64 \mathrm{QAM}^{17}$, sendo que cada uma delas apresenta uma taxa de símbolos ${ }^{18}$ diferente. Para o COFDM, em específico, podem ser especificados outros parâmetros como, número de portadoras do OFDM, intervalo de guarda entre portadoras e a taxa de códigos. Esses parâmetros são descritos extensamente por Faria (FARIA, 2000).

Estudos na literatura científica (BERTELLA ET AL, 2000) indicam que a recepção móvel no DVB-T, que utiliza o esquema de modulação COFDM, tem melhor desempenho com o tipo de modulação QPSK, para o qual cada símbolo representa 2 bits; em detrimento do 16QAM, onde cada símbolo representa 4 bits; e do 64QAM, com 6 bits por símbolo. Pode ser verificado, portanto, que a taxa de bits para a recepção móvel com qualidade é geralmente menor, pois deve ser utilizado um tipo de modulação mais robusto em termos de relação sinal-ruído, como o QPSK. A robustez do QPSK vem do fato de cada símbolo representar um número menor de bits. Por isso, a reconstrução do sinal torna-se mais fácil para um nível de ruído mais

\footnotetext{
${ }^{14}$ O Símbolo, do inglês baud, é um dos estados possíveis do sinal modulado. Nas modulações digitais, esse estado pode ser um nível de tensão da portadora, ASK (Amplitude Shift Keying), um valor de fase da portadora, PSK (Phase Shift Keying), um valor de freqüência da portadora, FSK (Frequency Shift Keying) ou uma combinação desses elementos, QAM (Quadrature Amplitude Modulation).

${ }^{15}$ QPSK, Quadrature Phase Shift Keying.

16 16QAM, 16 Quadrature Amplitude Modulation.

${ }^{17}$ 64QAM, 64 Quadrature Amplitude Modulation.

${ }^{18}$ A taxa de símbolos, baud rate, é a medida da taxa de sinalização no meio de transmissão, ou seja, indica o número de mudanças por segundo do sinal modulado. A taxa de símbolos não deve ser confundida com a taxa de bits. Cada estado do sinal modulado pode transportar um ou mais bits. Por exemplo, 8 bits no 256QAM. Ainda exemplificando, o sinal pode variar sua amplitude 250 vezes por segundo, ou seja, o baud rate é 250. Entretanto, se tivermos quatro níveis diferentes de amplitude do sinal, cada um deles poderá representar 2 bits e portanto a taxa de bits será de 500 bits por segundo.
} 
Conceitos básicos da radiodifusão de sinais de TV digital para recepção móvel

elevado. Sendo assim, a relação sinal-ruído necessária para a recepção do sinal é menor.

Para comprovar a afirmação de que para a transmissão de sinais destinados a recepção móvel são obtidas taxas de bits menores, são apresentados os resultados obtidos por Bertella et al (BERTELLA ET AL, 2000), por meio de testes de campo do padrão DVB-T com o esquema de modulação COFDM, utilizando parâmetros e tipos de modulação diferentes. Esses resultados são apresentados na tabela 2.1.

Tabela 2.1 - Taxas de bits para dois esquemas de modulação do COFDM para canal de $8 \mathrm{MHz}$.

\begin{tabular}{|l|c|c|c|c|}
\hline $\begin{array}{c}\text { Tipo de } \\
\text { Modulação }\end{array}$ & $\begin{array}{c}\text { FFT (Número de } \\
\text { Coeficientes) }^{\mathbf{1 9}}\end{array}$ & $\begin{array}{c}\text { Taxa de } \\
\text { Códigos }^{\mathbf{1 9}}\end{array}$ & $\begin{array}{c}\text { Intervalo de } \\
\text { Guarda }^{\mathbf{1 9}}\end{array}$ & $\begin{array}{c}\text { Taxa de bits } \\
\text { (Mbps) }\end{array}$ \\
\hline QPSK & $2 \mathrm{k}$ & $1 / 2$ & $1 / 32$ & 6,03 \\
\hline 64QAM & $8 \mathrm{k}$ & $2 / 3$ & $1 / 32$ & 24,13 \\
\hline
\end{tabular}

Considerando-se a taxa de bits para um programa de TV (áudio, vídeo e informações de serviço) com resolução SDTV (MPEG2, Standard Definition Television, com quadros de 768 pixels x 576 linhas, relação de aspecto 4:3 e 25 quadros por segundo em modo progressivo) obtemos aproximadamente $4 \mathrm{Mbps}$ para uma qualidade satisfatória. Portanto, para a modulação QPSK, pode ser transmitido um único programa por canal de TV digital ${ }^{20}$. Para a modulação 64QAM, por outro lado, podem ser transmitidos 6 programas.

A partir dos dados da tabela 2.1, pode ser questionada a viabilidade da multiprogramação com a digitalização do sinal de TV e para a configuração de modulação adequada à recepção móvel. Observa-se que em cada canal de radiodifusão somente um programa em SDTV poderia ser transmitido. Seriam necessários, portanto, mecanismos para melhorar a codificação de vídeo e áudio, de

\footnotetext{
${ }^{19}$ FFT (Fast Fourier Transform) representa o número de portadoras. A Taxa de Códigos é a razão entre o número de bytes dos códigos de correção e o número de bytes de informação. E o Intervalo de Guarda é o tempo reservado entre duas portadoras. Os parâmetros do esquema de modulação COFDM são melhor descritos em Faria (FARIA, 2000).

${ }^{20}$ BERTELLA ET AL (2000) utilizaram canais de $8 \mathrm{MHz}$, ou seja, para a especificação brasileira que utiliza canais de $6 \mathrm{MHz}$ seriam obtidas taxas de bits menores para a mesma eficiência espectral (bps/Hz).
} 
Conceitos básicos da radiodifusão de sinais de TV digital para recepção móvel

maneira a otimizar o uso de largura de banda para a recepção móvel, onde a oferta de banda é mais restrita.

Outro aspecto importante para a recepção móvel é a área de cobertura dos transmissores. Segundo Fernández (FERNÁNDEZ, 2000), a máxima separação das antenas de dois transmissores adjacentes para o esquema de modulação COFDM com FFT de 2k e intervalo de guarda 1/32, características apontadas pelos autores como ideais para a recepção móvel, é de dois quilômetros. Sendo assim, para a radiodifusão de sinais de TV digital com recepção móvel, devem ser instalados centenas de transmissores (estações geradoras e retransmissoras) para cobrir a área de uma grande região metropolitana, como a da cidade de São Paulo.

Pode-se concluir que se torna necessário implementar uma rede de transmissores para cobrir uma cidade de médio ou grande porte. De forma análoga a uma rede celular, as antenas transmissoras devem estar espaçadas de acordo com predições de cobertura, considerando-se a potência do sinal, a atenuação, relação sinal-ruído, etc., definindo-se uma região de cobertura para cada célula e assim garantindo que a área desejada seja atendida por pelo menos um transmissor. $\mathrm{Na}$ próxima seção serão descritas algumas opções para a rede de transmissores mencionada acima.

\subsubsection{Redes de distribuição de conteúdo na TV Digital Móvel}

A rede de transmissores para aplicações de TV digital, ao contrário da rede celular, pode ser de duas formas: Rede de freqüência única (SFN - Single Frequency Network) ou de múltiplas freqüências (MFN - Multiple Frequency Network) (FERNÁNDEZ, 2000). As redes MFN utilizam um conjunto de freqüências que são reutilizadas de forma a evitar interferências co-canal entre células ${ }^{21}$ vizinhas. No caso de uma rede MFN para TV digital, cada antena transmissora utilizaria uma determinada freqüência que não seria reutilizada pelos transmissores de células adjacentes, sendo reutilizada somente por transmissores distantes. Uma rede SFN, por sua vez, utilizaria uma única freqüência para todos os transmissores. Apesar da aparente simplificação devido a utilização de uma única freqüência, as SFNs

\footnotetext{
${ }^{21}$ Uma célula, numa rede móvel, é caracterizada como a área de cobertura de uma determinada antena transmissora.
} 
Conceitos básicos da radiodifusão de sinais de TV digital para recepção móvel

apresentam limitações de sincronismo bastante importantes (FERNÁNDEZ, 2000), pois, todas as antenas transmissoras devem estar sincronizadas em termos de freqüência, tempo e bits. O sincronismo nas freqüências é obtido por meio da utilização de um relógio comum para todas as células, no tempo, por meio da transmissão de cada símbolo em instantes de tempo próximos em relação às demais células; e, nos bits, por meio da transmissão de cada símbolo em instantes de tempo próximos para todas as células.

A rede de transmissores deve irradiar o sinal de TV digital para todos os terminais dentro da sua área de cobertura. A geração de conteúdo, entretanto, não é feita, na maioria das implementações, em cada transmissor e sim em uma localidade centralizada. Dessa forma, faz-se necessário distribuir esse conteúdo para todas as antenas transmissoras espalhadas geograficamente pela região desejada. Denominase rede primária de distribuição a infra-estrutura de transporte necessária para levar o conteúdo para as antenas transmissoras; e rede secundária de distribuição, a rede de transmissores propriamente dita.

A rede primária de distribuição pode transportar o sinal de TV digital já modulado conforme a especificação adotada, COFDM, 8-VSB, etc.; ou ainda em banda base. Nesse caso, o sinal é composto pelo MPEG2 Transport Stream, que será descrito no capítulo 3. Para cada tipo de sinal, modulado ou em banda base, deve ser especificada uma topologia de rede para a distribuição do conteúdo: Modulação Centralizada ou Modulação Distribuída.

Na Modulação Centralizada, os programas (vídeo, áudio e dados), gerados em um ponto central, são multiplexados e, em seguida, o sinal resultante é modulado. O sinal de TV modulado é, então, transportado pela rede primária até cada um dos transmissores.

Já na Modulação Distribuída, após a multiplexação do vídeo, do áudio e dos dados, o sinal digital resultante é transportado pela rede primária até cada um dos transmissores, onde é modulado. Cada transmissor deve ser equipado com um modulador para que seja gerado o sinal de TV para a transmissão. Nessa forma de distribuição de conteúdo, a modulação somente ocorre na estação transmissora.

A Modulação Distribuída tem duas vantagens principais: flexibilidade, pois na rede primária podem ser incluídos ou retirados programas do sinal 
Conceitos básicos da radiodifusão de sinais de TV digital para recepção móvel

multiplexado ${ }^{22}$; e qualidade do sinal, pois a relação sinal-ruído é praticamente preservada na rede primária. Por outro lado, a Modulação Centralizada dispensa a necessidade de moduladores em todos os transmissores, mas questões de qualidade são críticas devido à degradação da relação sinal-ruído na rede primária, que se reflete em uma menor cobertura e conseqüentemente em um número maior de transmissores. Além disso, perde-se a flexibilidade da remultiplexação de programas.

A rede primária introduz desafios para a implementação da TV digital, tanto para recepção móvel quanto para recepção fixa. No caso da rede primária ser uma rede de pacotes, questões como atraso, variação de atraso, sincronismo no receptor, etc, deverão ser examinadas para garantir uma qualidade satisfatória no terminal final.

Se o desenvolvimento da TV digital no Brasil tiver como objetivo transformar os mecanismos de produção de conteúdo para TV, hoje nas mãos de poucos grupos, democratizando o acesso aos meios de comunicação de massa, questões como a remultiplexação de programas ganharão um destaque ainda maior. A remultiplexação é a base para a introdução de nova programação aos sinais digitais de TV transmitidos pela rede secundária. Portanto, definições sobre a estrutura da rede primária, onde a remultiplexação é implementada, também deverão ser feitas.

$\mathrm{Na}$ figura 2.1 é apresentado um diagrama contendo os elementos das redes primária e secundária para a transmissão de TV digital numa rede SFN com Modulação Distribuída. Observa-se que a rede primária é uma rede de dados qualquer (ATM, PDH, SDH, etc) e que cada transmissor contém um modulador associado.

\footnotetext{
${ }^{22} \mathrm{O}$ processo de inclusão e/ou retirada de programas de um sinal multiplexado é denominado remultiplexação. A remultiplexação é bastante útil para incluir variações regionais à programação.
} 


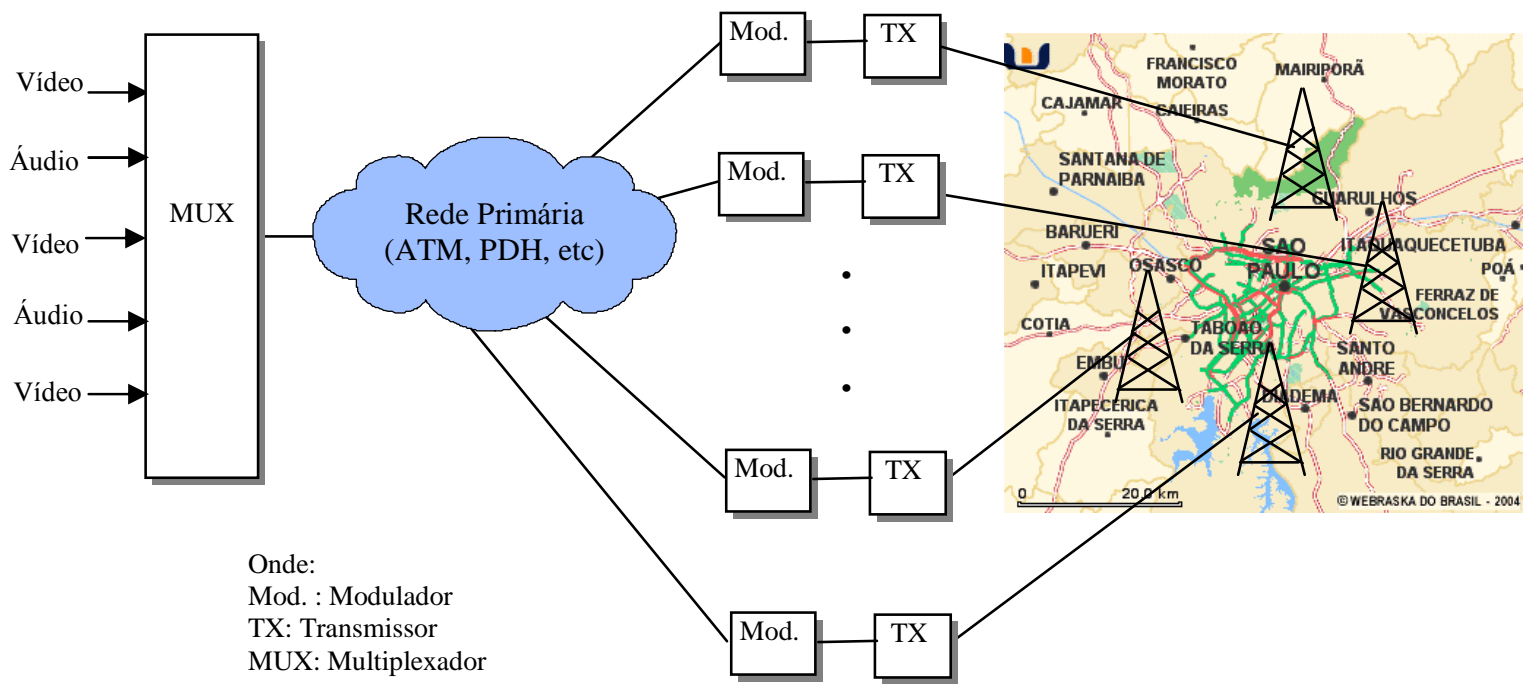

Figura 2.1 - Redes para transmissão de TV digital terrestre.

Apresentados os elementos principais para a transmissão de TV digital, faz-se necessário discutir em maiores detalhes as implicações de tal configuração em aplicações de TV digital com recepção móvel. Na seção 2.3, são relacionadas as principais questões que envolvem a transmissão de sinais de TV multiplexados numa rede primária de distribuição implementada por uma rede de dados, onde atrasos, variação de atraso, etc, são importantes. Além disso, serão apontados alguns problemas decorrentes da transmissão de sinais de TV digital para recepção móvel.

\subsection{Desafios da Radiodifusão de TV Digital para Recepção Móvel}

A radiodifusão de TV digital, tanto para recepção fixa como para recepção móvel, depende em grande medida de dois aspectos importantes: a implementação da rede primária e a eficiência no uso da banda disponível nos canais de transmissão através da interface aérea.

Se não forem definidas alternativas para resolver os diversos desafios impostos pela utilização de redes primárias para distribuição de conteúdo, os serviços da TV digital serão prejudicados e não apresentarão a qualidade de imagem e a multiplicidade de programação prometidas pela tecnologia digital. Por conseguinte, 
Conceitos básicos da radiodifusão de sinais de TV digital para recepção móvel

devem ser considerados, na análise de redes de distribuição, os diversos métodos de transmissão, ou seja, redes de pacotes, transmissão via satélite, rede de comutação telefônica, etc. Além disso, devem ser analisados os desafios da transmissão de informações por canais de radiodifusão.

No caso específico da aplicação de TV digital com recepção móvel, a transmissão pelos canais de radiodifusão tem restrições de banda e, portanto, a eficiência espectral é um fator ainda mais crítico. Para garantir a eficiência na utilização do canal de radiodifusão os mecanismos listados abaixo devem ser observados:

- Mecanismos de modulação: Modulações diferentes podem apresentar ganhos diferentes em termos de taxas de transmissão e portanto podem representar ganhos na eficiência do uso do canal de radiodifusão, ou seja, uma relação bps e Hz maior;

- Mecanismos de codificação e compressão de mídias: A codificação/compressão envolve a representação das informações de cada programa, ou seja, vídeos, áudio e dados, em um número reduzido de bits, o que em última análise permite um uso mais eficiente do canal de radiodifusão;

- Mecanismos de transporte de mídias e dados: Por meio do transporte eficiente das mídias e/ou dados através, por exemplo, do compartilhamento e/ou multiplexação de cada canal de transmissão, pode-se implementar o transporte de diversos vídeos, áudio e dados conjuntamente. Além disso, cada mecanismo tem uma sobrecarga de informações para suporte (cabeçalhos de pacotes, etc) e, portanto com a otimização desses mecanismos pode-se atingir melhor eficiência no uso do canal de radiodifusão.

Além da eficiente utilização do canal de radiodifusão, a implementação da rede primária tem impactos na apresentação de vídeo e áudio em terminais de TV digital para recepção móvel. A transmissão de sinais de TV digital através dessa rede pode introduzir imperfeições ao sincronismo do receptor, pois os sinais transmitidos estarão sujeitos a atrasos, variação de atraso, perdas de pacotes, congestionamento nos roteadores, etc. 
Conceitos básicos da radiodifusão de sinais de TV digital para recepção móvel

Por outro lado, a rede primária implementada por uma rede de pacotes é uma opção importante para o serviço de TV digital, devido a sua flexibilidade e ampla utilização no transporte de qualquer espécie de dados. Os principais desafios para a implementação de uma rede primária com tecnologias de rede de pacotes são apresentados abaixo:

- Aspectos de qualidade de serviço, tais como: atraso, variação de atraso, perda de pacotes e largura de banda;

- Remultiplexação de Programas, que envolve a geração de uma nova estrutura para o transporte de mídias com os novos programas inseridos ou sem os programas retirados. Além disso, os mecanismos de remultiplexação devem ser eficientes para não introduzirem atrasos ou variação de atraso da transmissão de TV digital que poderão refletir em problemas na recepção pelo terminal do usuário;

- Adaptação e interoperabilidade de protocolos para o encapsulamento dos sinais de TV digital em protocolos de transporte amplamente utilizados como o TCP, o ATM, etc.

Alguns dos aspectos apontados acima serão discutidos nos capítulos seguintes desta dissertação, principalmente aqueles ligados à rede primária e, em especial, à influência de atrasos e variações de atraso adicionadas pela rede primária no sincronismo das mídias no receptor. Serão discutidas alternativas para a ressincronização de programas MPEG2 transportados por redes primárias de dados. Não é objetivo desse trabalho, discutir a modulação e a codificação/compressão de mídias. Entretanto, onde necessário, serão abordados temas de relevância para o entendimento dos mecanismos propostos. 


\section{MULTIPLEXAÇÃO NA INFRA-ESTRUTURA DE TV DIGITAL}

Neste capítulo são apresentados os principais aspectos do transporte de mídias digitais através de uma rede primária de distribuição de conteúdo para a TV Digital. Serão detalhados os mecanismos essenciais para implementar a multiplexação dos diversos fluxos de vídeo, áudio e dados enviados entre o transmissor e o receptor.

\subsection{Introdução}

A TV Digital introduz uma série de inovações e melhorias ao disponibilizar programação no formato digital aos telespectadores. A qualidade de imagem e som é sem dúvida melhor, mas a principal inovação é a capacidade de interação que a plataforma digital proporciona. A digitalização da transmissão de TV possibilita a interatividade entre o espectador e a fornecedora do conteúdo. Essa interação pode ser implementada de várias maneiras, por exemplo: Em um programa de TV transmitindo a apresentação de uma orquestra, o usuário não precisa se restringir à edição feita pelas emissoras como na TV analógica atual, podendo optar pela perspectiva que mais the agradar a cada momento e, assim, modificar a câmera que deseja assistir. Além dessa aplicação ${ }^{23}$, diversas outras são possíveis, tais como: seleção do áudio de naipes de instrumentos (cordas, metais, madeiras ou percussão), obtenção de informações adicionais sobre a peça apresentada, o compositor, o regente, os músicos, etc. Nota-se que cada programa na TV digital pode ser formado por diversos vídeos, áudios e dados. No exemplo, cada câmera produz um fluxo de vídeo; cada naipe de instrumentos, um fluxo de áudio; e as informações adicionais são fluxos de dados.

Pode-se imaginar que a organização de todas essas mídias digitais em um único meio de transmissão (canal de radiodifusão, cabo coaxial, fibra ótica, pares metálicos, etc) não é tarefa fácil. O processo utilizado para reunir todas essas

\footnotetext{
${ }^{23}$ A TV Cultura e o Laboratório de Arquitetura e Redes de Computadores (LARC) da EPUSP desenvolveram uma aplicação nesses moldes.
} 
Multiplexação na infra-estrutura de TV digital

informações é denominado multiplexação. Adicionalmente, na nomenclatura MPEG, cada mídia - vídeo, áudio e dado - é denominada fluxo elementar (ES, Elementary Stream) e quando os fluxos elementares são empacotados eles passam a ser designados fluxos elementares empacotados (PES, Packetized Elementary Streams). Os fluxos elementares que possuem uma base de tempo comum formam, por sua vez, um programa (ISO 13818-1, 1994).

O MPEG2 é a família de padrões proposta pelo grupo MPEG (Moving Pictures Expert Group) da ISO (International Standardization Organization) que define as bases para a codificação, a compressão e o transporte de vídeo e áudio. $\mathrm{Na}$ tabela 3.1 são apresentados os padrões da família MPEG2, dentre os quais se destaca o ITU-T Rec. H.222.0 / ISO/IEC 13818-1, também denominado MPEG2 System (ISO 13818-1, 1994). É nesse padrão que são definidas regras, protocolos e mecanismos para a multiplexação e transporte de vídeo, áudio e outras mídias digitais através de um meio de transmissão qualquer, e é por esse motivo que o padrão ISO 13818-1 é fundamental para a implementação da TV Digital em seu nível mais elementar, ou seja, na infra-estrutura de transmissão de pacotes (camada de enlace).

Tabela 3.1 - Padrões da Família MPEG2.

\begin{tabular}{|l|l|}
\hline Número do Padrão & Nome do Padrão \\
\hline ISO/IEC 13818-1 & MPEG2 System \\
\hline ISO/IEC 13818-2 & MPEG2 Video \\
\hline ISO/IEC 13818-3 & MPEG2 Audio \\
\hline ISO/IEC 13818-4 & MPEG2 Conformance \\
\hline ISO/IEC 13818-5 & MPEG2 Software \\
\hline ISO/IEC 13818-6 & Digital Store Media - Command and Control (DSM-CC) \\
\hline ISO/IEC 13818-7 & Non Backward Compatible (NBC) Áudio \\
\hline ISO/IEC 13818-8 & 10-Bit Vídeo (Este padrão foi descontinuado) \\
\hline ISO/IEC 13818-9 & Real Time Interface \\
\hline ISO/IEC 13818-10 & Digital Store Media - Command and Control (DSM-CC) Conformance \\
\hline
\end{tabular}

$\mathrm{Na}$ figura 3.1 é apresentado um diagrama esquemático mostrando a multiplexação para um número qualquer de programas de TV. Pode ser verificado que o transporte de dados entre transmissor e receptor é feito através da interface 
aérea por radiodifusão, e que as mídias são agrupadas antes de serem enviadas ao transmissor. De forma similar, no receptor, é feito o processo inverso e, assim, apresenta-se ao telespectador o programa correto na configuração escolhida por ele. O mecanismo pelo qual se obtém o fluxo elementar dentro do programa desejado pelo usuário é denominado demultiplexação.

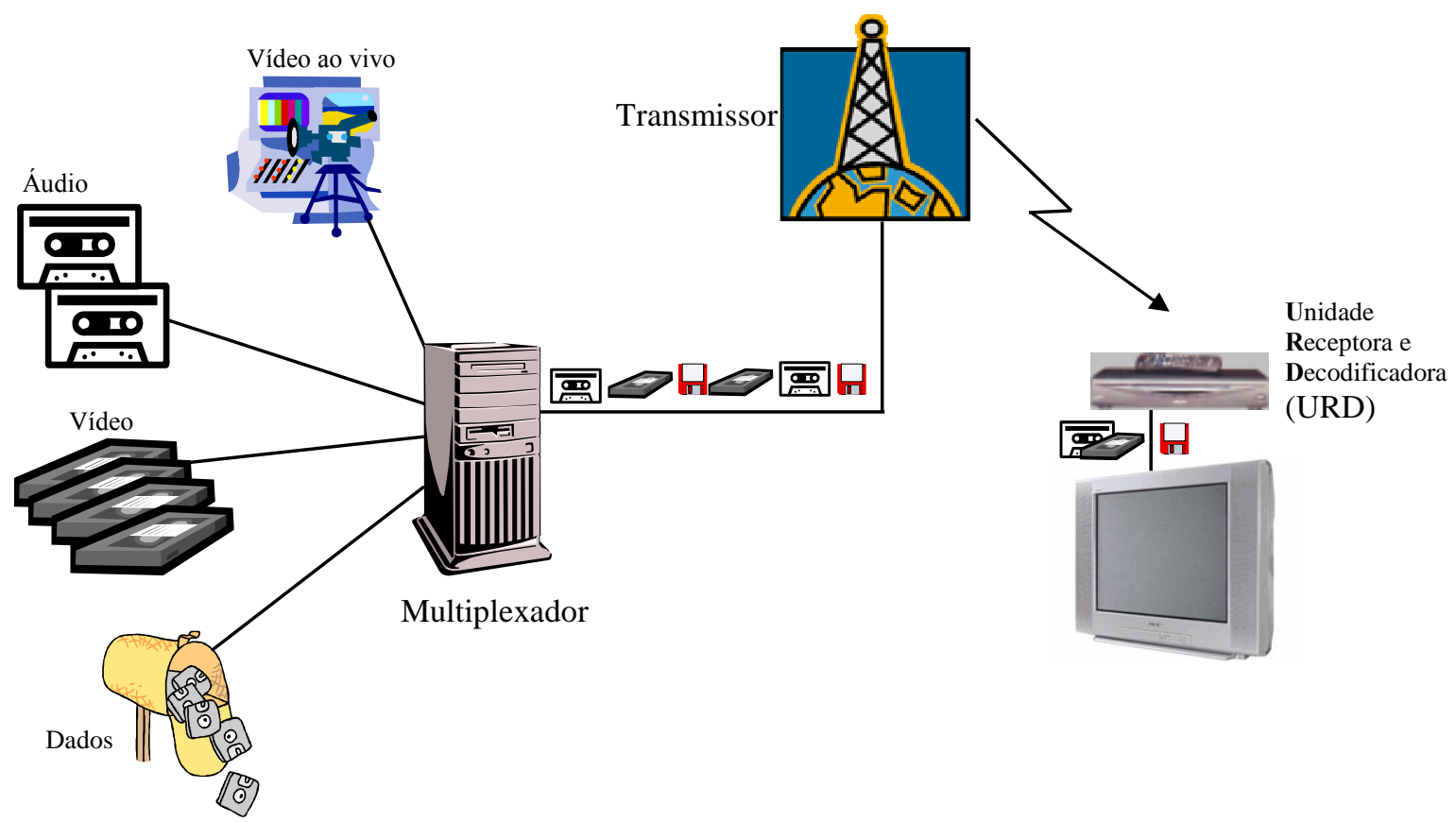

Figura 3.1 - Diagrama Esquemático da Multiplexação e Demultiplexação na TV Digital.

Nas duas próximas seções, são descritos os mecanismos utilizados para multiplexar e demultiplexar fluxos elementares de diversas mídias e programas diferentes. A seção 3.2 apresenta os conceitos gerais da multiplexação e a seção 3.3, a estrutura de pacotes utilizada para implementá-la.

\subsection{Conceitos gerais da multiplexação}

A multiplexação é o processo pelo qual mídias diferentes são reunidas em um único meio de transmissão. Seu objetivo, no contexto da TV digital, é transportar vídeo, áudio e dados (fluxos elementares) em um único fluxo de pacotes. Esta seção 
Multiplexação na infra-estrutura de TV digital

apresenta os conceitos gerais da multiplexação na infra-estrutura da TV digital: os principais mecanismos de multiplexação para a TV digital e as tabelas de informações do serviço, utilizadas para auxiliar a recuperação do conteúdo multiplexado.

A Multiplexação é feita por meio do encapsulamento de cada fluxo elementar, ou dos pacotes PES, em outra estrutura de pacotes devidamente identificados, de forma que as informações possam ser separadas no receptor. $\mathrm{Na}$ nova estrutura, os pacotes podem ter tamanho fixo ou variável. Com tamanho variável, o fluxo resultante é denominado Fluxo de Programa (PS - Program Stream); e com tamanho fixo, Fluxo de Transporte (TS - Tranport Stream). A figura 3.2 contém um diagrama que mostra a formação dos fluxos multiplexados PS e TS a partir de vídeos e áudios não comprimidos.

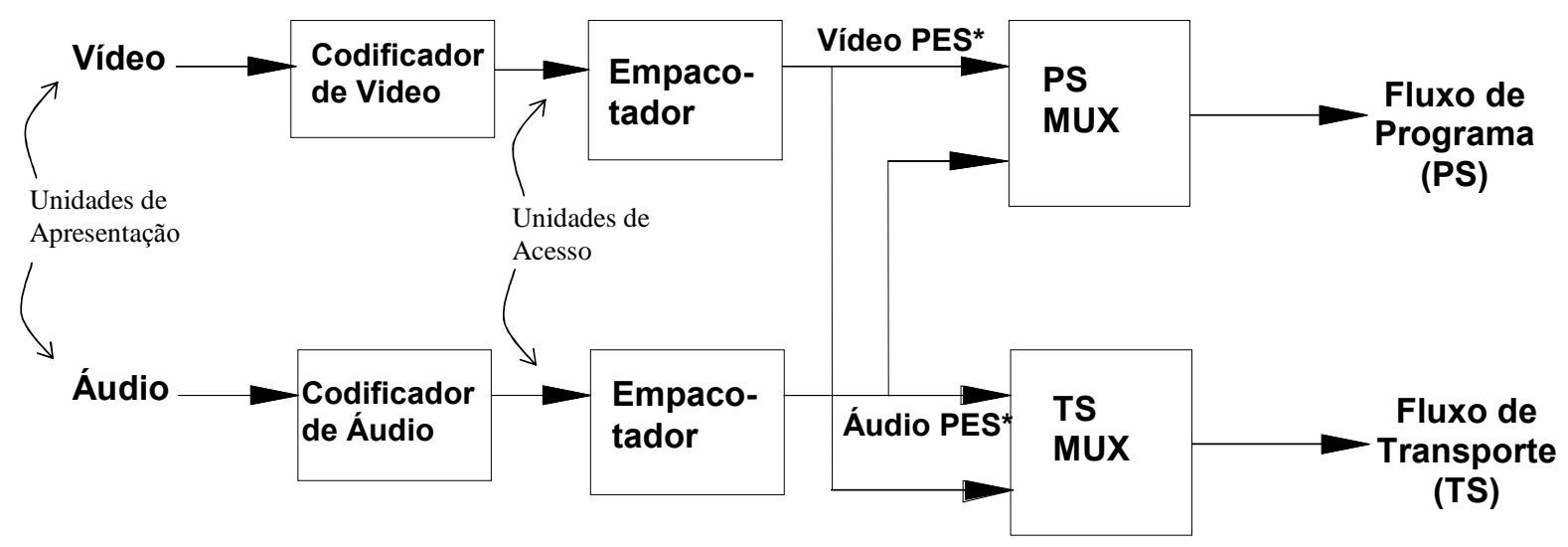

\begin{tabular}{|c|c|c|c|c|c|c|c|c|c|c|c|c|c|c|}
\hline Áudio & Vídeo & Vídeo & Vídeo & Áudio & Vídeo & Vídeo & Vídeo & Áudio & Vídeo & Vídeo & Vídeo & Áudio & Vídeo & Vídeo \\
.0 & \multicolumn{1}{c}{$\begin{array}{c}\text { Fluxo de Transporte } \\
\text { (tamanho fixo) }\end{array}$}
\end{tabular}

\begin{tabular}{|l|l|l|l|}
\hline Áudio & Vídeo & Áudio & Vídeo \\
\hline
\end{tabular}

Fluxo de Programa

(tamanaho variável)

(*) PES: Packetized Elementary Stream (unidades de acesso empacotadas)

Figura 3.2 - Multiplexação no Fluxo de Programa e de Transporte (ISO

13818-1, 1994). 
Multiplexação na infra-estrutura de TV digital

Na figura 3.2, vídeo e áudio não comprimidos são denominados "Unidades de Apresentação" e, após a compressão, se tornam "Unidades de Acesso". O conjunto de unidades de acesso, por sua vez, forma um Fluxo Elementar. A nomenclatura utilizada para esses diversos elementos corresponde aos termos padronizados pelo MPEG2 System (ISO 13818-1, 1994).

Nota-se também que, em ambos os fluxos (TS e PS), cada pacote é utilizado para transportar uma mídia diferente. No entanto, no Fluxo de Programa, cada pacote é variável e pode carregar, por exemplo, um quadro completo de vídeo ou de áudio, ou um pacote PES inteiro. De fato, o Fluxo de Programa é uma estrutura de pacotes que reúne vários pacotes PES no seu campo de dados e que possui um cabeçalho denominado Pack Header. No Fluxo de Transporte, os pacotes são pequenos e de tamanho fixo, por isso o conteúdo (quadros de vídeo ou áudio, ou dados) deve ser fragmentado em pedaços menores. Devido a sua estrutura, é utilizado em aplicações de comunicação de mídias por meios não confiáveis (interface aérea, cabos coaxiais, etc), por exemplo: transmissão de TV digital Terrestre, aplicações de vídeo sobre banda larga, etc. Já o Fluxo de Programa é mais utilizado em aplicações onde não é necessária a transmissão das mídias por meios não confiáveis, por exemplo, DVD.

Ao contrário do Fluxo de Programa (PS), o Fluxo de Transporte (TS) pode ser associado a programas diferentes. Essa é a diferença básica entre PS e TS, sendo esse um dos motivos para a utilização do TS nas transmissões da TV Digital, que são naturalmente compostas por diferentes canais de diversos provedores de conteúdo. Outra diferença importante é o fato dos fluxos elementares no PS possuírem uma base de tempo única, ou seja, no PS um único programa é transportado. No TS, por outro lado, podem ser transportados vários programas, que podem ou não ter uma referência de tempo comum (TRYFONAS, 1999). Ou seja, dentro de um fluxo de transporte, cada programa pode ter sua própria linha de tempo ${ }^{24}$. Na tabela 3.2 abaixo são apresentadas algumas diferenças do TS e do PS.

\footnotetext{
${ }^{24}$ Linha de tempo, do inglês timeline, representa o eixo do tempo e é utilizada como referência para todos os vídeos, áudios e aplicações de um determinado programa. O sincronismo da apresentação do vídeo e áudio, e também das aplicações, é feito, levando em consideração essa linha de tempo.
} 
Multiplexação na infra-estrutura de TV digital

Tabela 3.2 - Comparação entre os fluxos de transporte (TS) e programa (PS).

\begin{tabular}{|c|c|c|}
\hline & Fluxo de Transporte (TS) & Fluxo de Programa (PS) \\
\hline Tamanho de Pacotes & Fixo & Variável \\
\hline Programas MPEG & Vários programas & Um único programa \\
\hline Base de tempo & $\begin{array}{c}\text { Pode ou não ter base de } \\
\text { tempo comum }\end{array}$ & $\begin{array}{c}\text { Possui uma única base de } \\
\text { tempo }\end{array}$ \\
\hline Aplicações & $\begin{array}{c}\text { Transporte em meios de } \\
\text { transmissão não confiáveis. }\end{array}$ & $\begin{array}{c}\text { Armazenagem e recuperação } \\
\text { de mídias de DVD, CD, etc. }\end{array}$ \\
\hline
\end{tabular}

O processo de multiplexação no PS é mais intuitivo e direto. Cada pacote na estrutura do PS é geralmente uma reunião de fluxos elementares empacotados, sendo que cada um dos pacotes PES tem uma identificação do tipo de fluxo elementar sendo transportado (vídeo ou áudio). A demultiplexação é feita, reunindo todos os pacotes PES que possuem identificadores iguais. A estrutura do pacote PES e o identificador de fluxos elementares são detalhados nas próximas seções.

Para ilustrar o processo de multiplexação no Fluxo de Transporte, na figura 3.3, é examinada uma seqüência de pacotes de um TS, contendo vários fluxos elementares para vídeo, áudio e dados diferentes, para várias fontes. Cada pacote tem um identificador denominado PID (Packet Identifier), sendo possível classificar os pacotes em grupos distintos. No exemplo da figura podem ser identificados três grupos (PID 51, 46 e 30), sendo que cada um deles pode ser comparado a um circuito virtual fim-a-fim, cuja identidade lógica é o PID.

Assim, pode-se combinar diversos fluxos elementares e transmiti-los em conjunto, associando um PID diferente para cada fluxo. Na figura 3.3, o PID 46 está transportando os quadros de um vídeo, o PID 51 transporta os quadros de um áudio e o PID 30, dados das tabelas de informação específica de programa (PSI, Program Specific Information). 
Multiplexação na infra-estrutura de TV digital

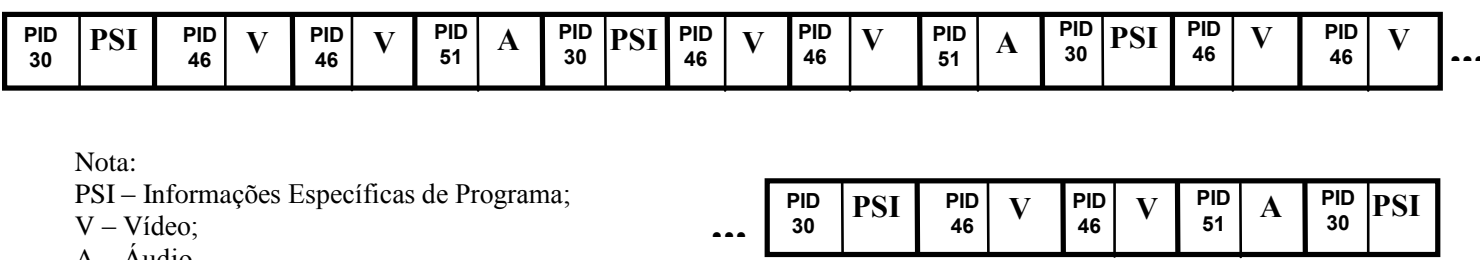

Figura 3.3 - Fluxo de pacotes TS exemplificando a multiplexação de informações.

Além de sua natureza multi-programas, um Fluxo de Transporte (TS) pode ser construído por fluxos elementares provenientes de diversas fontes. As informações que formam um TS não precisam ter a mesma origem. Podem ser reunidos em um único TS: um ou mais fluxos elementares/programas oriundos de um codificador MPEG, programas de Fluxos de Programa (PS), ou programas de outros TS (ISO 13818-1, 1994). Algoritmos que implementam a remultiplexação ${ }^{25}$ dos diversos fluxos TS e/ou PS (YU; NAHRSTEDT, 2002; TRYFONAS; VARMA, 1999a; TRYFONAS; VARMA, 1999b; NORO; HUSBAUX, 1999) são utilizados para gerar o TS final.

A construção de um Fluxo de Transporte a partir de diversas fontes é ilustrada pela figura 3.4, que mostra a divisão lógica dos pacotes de um TS formado por dois Fluxos de Transporte diferentes, cada um com seus diversos programas (e conseqüentemente, fluxos elementares).

Observa-se, na figura 3.4, que os pacotes do TS final estão embaralhados no meio físico e não há uma multiplexação temporal de "canais". Em outras palavras, não há restrições quanto à ordem dos pacotes preenchidos com os diversos fluxos elementares, exceto à ordem cronológica dos pacotes que pertencem a um mesmo fluxo elementar (TRYFONAS, 1999). Pode-se entender o Fluxo de Transporte como uma forma de multiplexação estatística dos fluxos elementares através dos pacotes do TS.

\footnotetext{
${ }^{25}$ Remultiplexação é o processo pelo qual os fluxos elementares e programas de fluxos multiplexados originais são mapeados em um novo fluxo multiplexado. Envolve o remapeamento de PID, e a criação de novas tabelas PSI.
} 


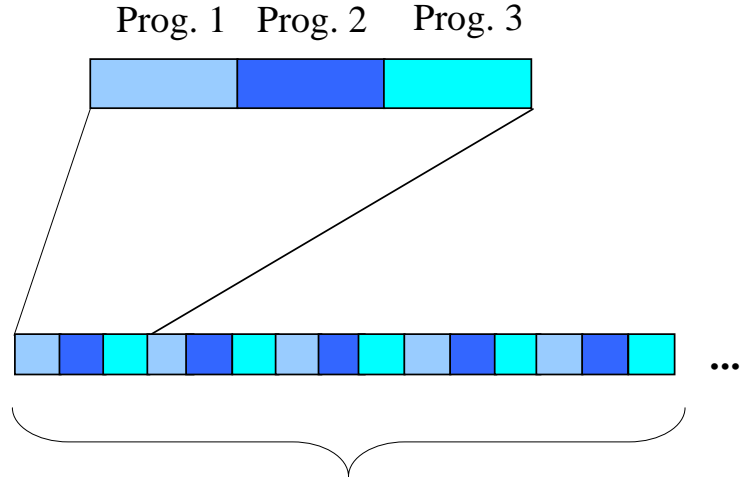

Fluxo de Transporte 1
Prog. 1 Prog. 2 Prog. 3

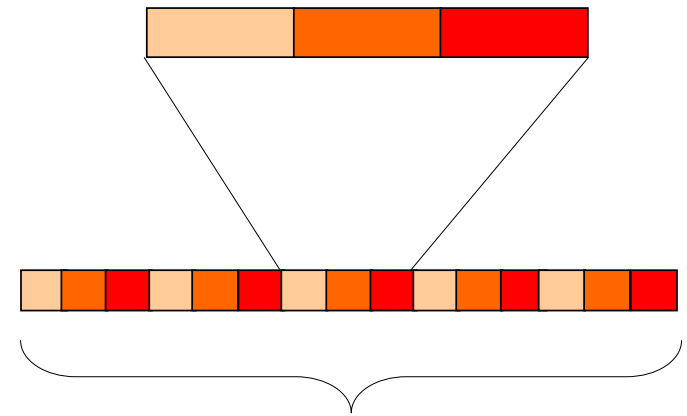

Fluxo de Transporte 2

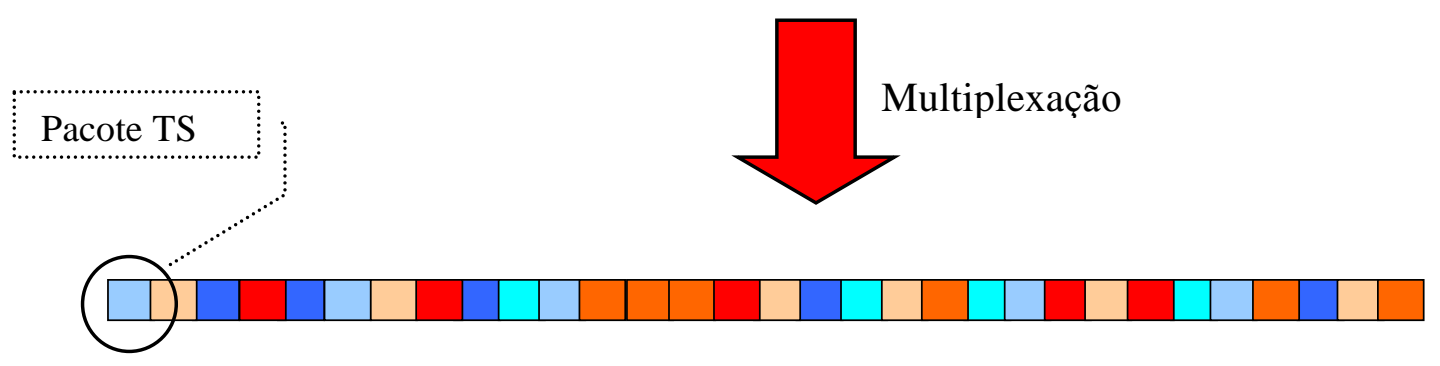

Figura 3.4 - Estrutura multi-fluxos e multi-programas dos Fluxos de Transporte (TS).

\subsubsection{Tabelas PSI e DVB-SI}

Os programas de Fluxos de Transporte diferentes são transmitidos em um mesmo meio de transmissão, sendo o PID o único identificador para diferenciar cada pacote dos demais. Uma pergunta surge dessas considerações: Como o multiplexador faz a associação entre programas, fluxos de transporte e PID? A resposta está nas tabelas de informações específicas de programa, PSI $^{26}$ (ISO 13818-1, 1994; EN 300 744, 2004; ETS 300 468, 2004; ARIB STD-10; 2001), definidas no MPEG2 System.

As tabelas PSI definidas pelo MPEG2 System são: PAT (Program Association Table), PMT (Program Map Table), CAT (Conditional Access Table) e Tabelas Privadas. Cada uma fornece informações diferentes ao receptor/demultiplexador do terminal cliente para que seja sintonizado o programa desejado do fluxo de transporte correto, ou seja, para possibilitar a demultiplexação dos pacotes com os PID corretos para o programa especificado.

\footnotetext{
${ }^{26}$ PSI, Program Specific Information.
} 
Multiplexação na infra-estrutura de TV digital

Um detalhamento de cada uma das tabelas PSI (ISO 13818-1, 1994; EN 300 744, 2004; ETS 300 468, 2004; ARIB STD-10; 2001), é apresentado a seguir, mostrando seus campos e sua finalidade para a demultiplexação/recepção dos fluxos de pacotes:

- PAT (Program Association Table): Faz a associação entre programas e os PID dos pacotes que contém a tabela PMT de cada programa. Contém informações como o identificador do fluxo (transport_stream_id), os números dos programas (program_number) e os PID das PMT (program_map_id, que é o ponteiro para a tabela PMT);

- PMT (Program Map Table): É apontada pela PAT, e indica quais fluxos elementares (vídeo, áudio, etc) estão associados a um determinado programa;

- CAT (Conditional Access Table): Faz a associação entre os sistemas de acesso condicional e as mensagens de acesso condicional EMM (Entitlement Management Messages) utilizadas pelo receptor no mecanismo de desembaralhamento dos dados transmitidos (BENOIT, 1997). Indica os PID que contêm as mensagens EMM;

- Tabela Privada: Tabela que pode ser utilizada por aplicações cliente para enviar informações privadas de interesse somente dessas aplicações.

Nas tabelas 3.3 a 3.6 são apresentadas as seções de cada umas das tabelas PSI (ISO 13818-1, 1994; EN 300 744, 2004; ETS 300 468, 2004; ARIB STD-10; 2001). A seção é a unidade básica de cada tabela PSI, sendo repetida quantas vezes necessário para estruturar a tabela como um todo. Uma tabela é uma seqüência de seções. Cada seção tem, no máximo, 1024 bytes para as tabelas PAT, PMT e CAT e 4096 bytes para as Tabelas Privadas. 
Multiplexação na infra-estrutura de TV digital

Tabela 3.3 - Estrutura de uma seção da tabela PAT.

\begin{tabular}{|c|c|c|}
\hline Sintaxe & Descrição do campo & No. de bits \\
\hline table_id & Indica o tipo de tabela, se 0x00 é PAT & 8 \\
\hline section_syntax_indicator & Campo com valor ' 1 ' & 1 \\
\hline '0’ & & 1 \\
\hline Reserved & & 2 \\
\hline section_length & $\begin{array}{l}\text { No. de bytes seguintes da seção (começa } \\
\text { com '00', máx } 1021 \text { bytes). }\end{array}$ & 12 \\
\hline transport_stream_id & Etiqueta que distingue o TS de outros. & 16 \\
\hline Reserved & & 2 \\
\hline version_number & Incrementa de 1 para cada versão da PAT. & 5 \\
\hline current_next_indicator & PAT atual ' 1 ', futura ' 0 '. & 8 \\
\hline section_number & No. da seção atual (primeira seção 0x00). & 8 \\
\hline last_section_number & No. da última seção da tabela PAT. & 2 \\
\hline program_number $=$ "0x0000" & Programa $n^{\circ} 0$ do multiplex $=$ Tabela NIT & 16 \\
\hline Reserved & & 3 \\
\hline network_PID & $\begin{array}{l}\text { PID dos pacotes TS que carregam a tabela } \\
\text { NIT. }\end{array}$ & 13 \\
\hline program_number $=$ " $0 \times 0001 "$ & Programa $\mathrm{n}^{\mathrm{o}} 1$ do multiplex. & 16 \\
\hline Reserved & & 3 \\
\hline \multirow[t]{2}{*}{ program_map_PID } & $\begin{array}{l}\text { PID dos pacotes TS que carregam a tabela } \\
\text { PMT do programa } 1 .\end{array}$ & 13 \\
\hline & $\mathrm{N}^{\mathrm{o}}$ do Programa. & 16 \\
\hline \multirow[t]{2}{*}{ (Dados dos demais programas) } & & 3 \\
\hline & $\begin{array}{l}\text { PID dos pacotes TS que carregam a tabela } \\
\text { PMT do programa. }\end{array}$ & 13 \\
\hline CRC32 & $\begin{array}{c}\text { Checagem dos bytes da seção, segundo } \\
\text { um polinômio, devendo } \\
\text { resultar=“0xFFFFFFFF”. }\end{array}$ & 32 \\
\hline
\end{tabular}

Tabela 3.4 - Estrutura de uma seção da tabela PMT.

\begin{tabular}{|c|c|c|}
\hline Sintaxe & Descrição do campo & No. de bits \\
\hline table_id & Indica o tipo de tabela, se 0x02 é PMT. & 8 \\
\hline section_syntax_indicator & Campo com valor ' 1 '. & 1 \\
\hline '0’' & & 1 \\
\hline Reserved & & 2 \\
\hline section_length & $\begin{array}{c}\text { No. de bytes seguintes da seção } \\
\text { (começa com '00', máx } 1021 \text { bytes). }\end{array}$ & 12 \\
\hline program_number & No. do programa associada a essa seção. & 16 \\
\hline Reserved & & 2 \\
\hline version_number & $\begin{array}{l}\text { Incrementa de } 1 \text { para cada versão da } \\
\text { PMT. }\end{array}$ & 5 \\
\hline current_next_indicator & PMT atual ' 1 ', futura '0'. & 1 \\
\hline section_number & $\begin{array}{c}\text { Sempre 0x00 } \\
\text { (só uma seção por programa). }\end{array}$ & 8 \\
\hline last_section_number & $\begin{array}{c}\text { Sempre 0x00 } \\
\text { (só uma seção por programa). }\end{array}$ & 8 \\
\hline Reserved & & 3 \\
\hline PCR_PID & $\begin{array}{l}\text { PID dos pacotes que levam o PCR } \\
\text { ("Program Clock Reference") do } \\
\text { programa. }\end{array}$ & 13 \\
\hline
\end{tabular}


Multiplexação na infra-estrutura de TV digital

\begin{tabular}{|c|c|c|}
\hline Reserved & & 4 \\
\hline |Program_info_length & $\begin{array}{c}\text { No. bytes do descritor seguindo esse } \\
\text { campo }(\mathrm{N}) .\end{array}$ & 12 \\
\hline Descriptor & Dados do Programa. & $\mathrm{N}$ \\
\hline stream_type $\left(\mathrm{n}^{\circ} .1\right)$ & Natureza do fluxo. & 8 \\
\hline Reserved & & 3 \\
\hline Elementary_PID $\left(\mathrm{n}^{\circ} .1\right)$ & PID que leva o fluxo elementar. & 13 \\
\hline Reserved & & 4 \\
\hline ES_info_length $\left(n^{\circ} .1\right)$ & $\begin{array}{l}\text { No. bytes do descritor seguindo esse } \\
\text { campo }\left(\mathrm{N}_{1}\right) \text {. }\end{array}$ & 12 \\
\hline Descriptor $\left(\mathrm{n}^{\circ} .1\right)$ & Dados sobre o fluxo elementar. & $\mathrm{N}_{1}$ \\
\hline & (Dados dos fluxos elementares 2 até M-1) & \\
\hline stream_type $\left(n^{\circ} . N\right)$ & Natureza do fluxo. & 8 \\
\hline Reserved & & 3 \\
\hline Elementary_PID $\left(\mathrm{n}^{\circ} . \mathrm{N}\right)$ & PID que leva o fluxo elementar. & 13 \\
\hline Reserved & & 4 \\
\hline ES_info_length $\left(\mathrm{n}^{\circ} . \mathrm{N}\right)$ & $\begin{array}{l}\text { No. bytes do descritor seguindo esse } \\
\text { campo }\left(\mathrm{N}_{\mathrm{M}}\right) \text {. }\end{array}$ & 12 \\
\hline Descriptor $\left(\mathrm{n}^{\circ} . \mathrm{N}\right)$ & Dados sobre o fluxo elementar. & $\mathrm{N}_{\mathrm{M}}$ \\
\hline CRC32 & $\begin{array}{c}\text { Checagem dos bytes da seção, segundo } \\
\text { um polinômio, devendo } \\
\text { resultar=“0xFFFFFFFF”. }\end{array}$ & 32 \\
\hline
\end{tabular}

Tabela 3.5 - Estrutura de uma seção da tabela CAT.

\begin{tabular}{|c|c|c|}
\hline Sintaxe & " Descrição do campo & No. de bits \\
\hline table_id & Indica o tipo de tabela, se 0x01 é CAT & 8 \\
\hline section_syntax_indicator & Campo com valor ' 1 ' & 1 \\
\hline ' 0 ' & & 1 \\
\hline Reserved & & 2 \\
\hline section_length & $\begin{array}{l}\text { No. de bytes seguintes da seção (começa com '00’, } \\
\text { máx } 1021 \text { bytes). }\end{array}$ & 12 \\
\hline Reserved & & 18 \\
\hline version_number & Incrementa de 1 para cada versão da PAT. & 5 \\
\hline current_next_indicator & CAT atual ' 1 ', futura ' 0 '. & 1 \\
\hline section_number & No. da seção atual (primeira seção 0x00). & 8 \\
\hline last_section_number & No. da última seção da tabela CAT. & 8 \\
\hline Descriptors & Informação de acesso condicional. & Até 1012 bytes \\
\hline CRC32 & $\begin{array}{l}\text { Checagem dos bytes da seção, segundo um } \\
\text { polinômio, devendo resultar= "OxFFFFFFFF". }\end{array}$ & 32 \\
\hline
\end{tabular}


Multiplexação na infra-estrutura de TV digital

Tabela 3.6 - Estrutura de uma seção de tabela Privada.

\begin{tabular}{|c|c|c|}
\hline Sintaxe & Descrição do campo & No. de bits \\
\hline table_id & Tabela privada, valor livre exceto 0x00 a 0xFF. & 8 \\
\hline section_syntax_indicator & Valor '1' sintaxe padrão, '0' sintaxe privada. & 1 \\
\hline private_indicator & Marcador definido pelo usuário. & 1 \\
\hline Reserved & & 2 \\
\hline private_section_length & $\begin{array}{l}\text { No. de bytes seguintes da seção (começa com } \\
\text { ' } 11^{\prime} \text { '). }\end{array}$ & 12 \\
\hline private_data_bytes & $\begin{array}{l}\text { Dados privados (até o final da seção caso } \\
\text { section_syntax_indicator='0', senão adota o } \\
\text { formato dos campos subseqüentes). }\end{array}$ & até 4093 bytes \\
\hline table_id_extension & Uso e valor definidos pelo usuário. & 16 \\
\hline Reserved & & 2 \\
\hline version_number & Incrementa de 1 para cada versão da tabela. & 5 \\
\hline current_next_indicator & Tabela atual ' 1 ', futura ' 0 '. & 1 \\
\hline section_number & No. da seção atual (primeira seção 0x00). & 8 \\
\hline last_section_number & No. Da última seção da tabela. & 8 \\
\hline private_data_bytes & Dados Privados. & Até 4096 bytes \\
\hline CRC32 & $\begin{array}{l}\text { Checagem dos bytes da seção, segundo um } \\
\text { polinômio, devendo resultar="0xFFFFFFFF" }\end{array}$ & 32 \\
\hline
\end{tabular}

As tabelas PAT e PMT são fundamentais para as transmissões de TV digital, pois é por meio delas que podemos "sintonizar" um fluxo elementar de um programa específico no receptor ou, em outras palavras, demultiplexar os pacotes TS de um determinado fluxo elementar associado a um programa. Na figura 3.5, um esquema de consulta às tabelas PSI, para uma configuração simples, é apresentado.

A tabela PAT é enviada sempre nos pacotes com PID 0 e contém os PID para as tabelas PMT para cada um dos programas válidos do TS. Na figura 3.5, foi associado o PID 16 ao programa 0; o PID 20, ao programa 1; e o PID 30, ao programa 2. Assim que o receptor lê a tabela PAT, é possível sintonizar um determinado programa. Para sintonizar, por exemplo, o programa 1, o receptor lê os pacotes com o PID 20 que contém a tabela PMT associada e assim descobre quais são os PID para os fluxos elementares desse programa. Em seguida, o receptor lê os pacotes cujos PID estão listados na tabela PMT e obtém os fluxos elementares, podendo assim decodificá-los e apresentá-los ao usuário. 
Multiplexação na infra-estrutura de TV digital

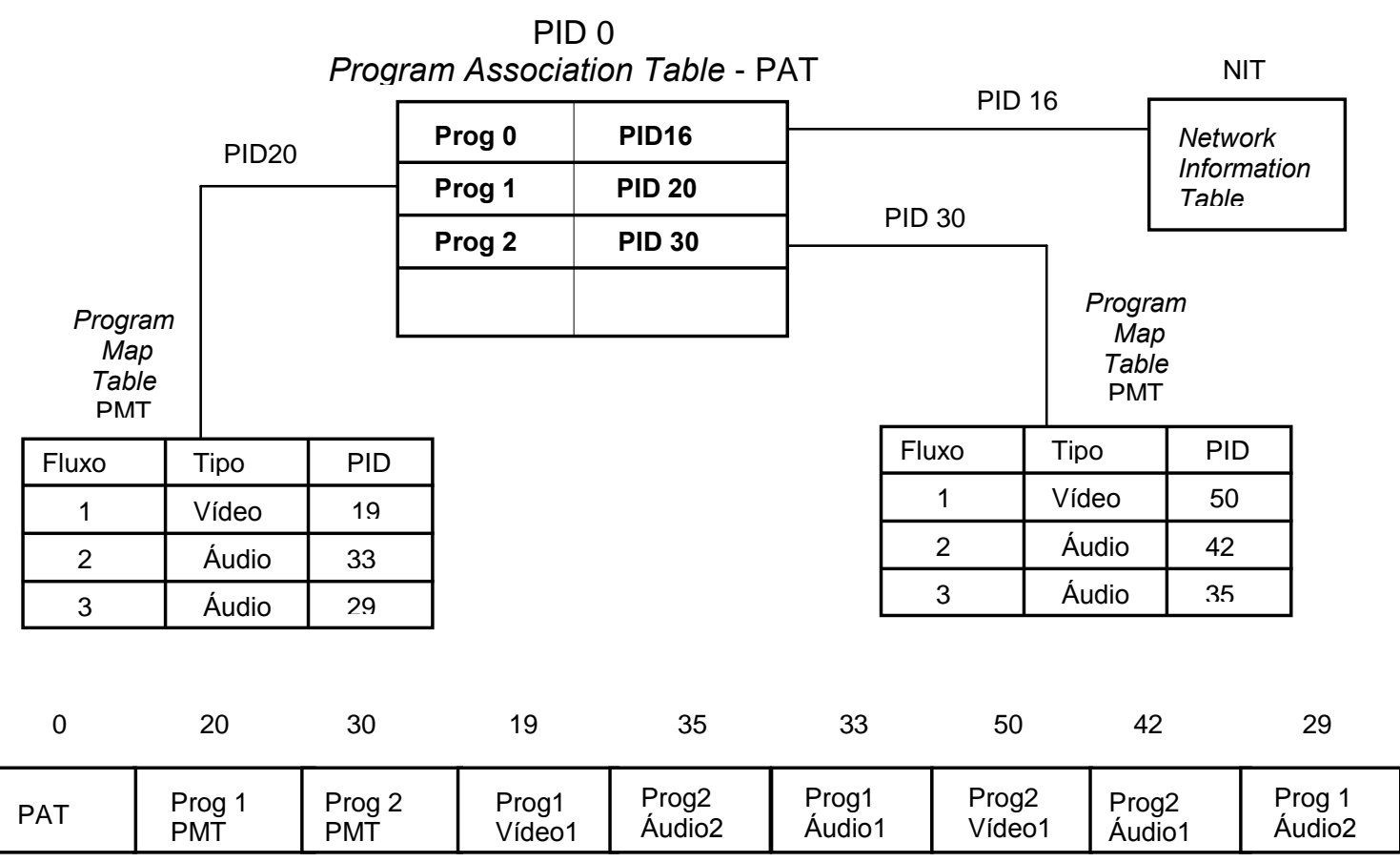

Figura 3.5 - Esquema de consulta das tabelas PAT e PMT.

As tabelas PSI são enviadas nos pacotes do Fluxo de Transporte junto com as demais informações. Contudo, são utilizados valores de PID reservados e amplamente conhecidos para que o receptor possa recebê-las periodicamente. Por exemplo, a tabela PAT deve ser enviada pelo PID 0x0000 ao menos a cada 100ms (ISO 13818-1, 1994; EM 300 744, 2004).

Além das tabelas PSI, cada padrão de TV Digital pode definir tabelas para uso próprio. O DVB definiu algumas tabelas denominadas DVB-SI (Service Information). Cada uma das tabelas DVB-SI tem uma finalidade específica e fornece informações importantes para a exibição dos programas no receptor e para a implementação de aplicações, por exemplo, os guias eletrônicos de programação. Enquanto as tabelas PSI estabelecem o relacionamento entre programas e conteúdo, as tabelas DVB-SI descrevem aspectos mais relacionados com o serviço, a rede e as aplicações. Abaixo são descritas brevemente as principais tabelas DVB-SI: 
Multiplexação na infra-estrutura de TV digital

- Tabelas Obrigatórias:

- NIT (Network Information Table): Fornece informações da rede física utilizada para transmitir o Fluxo de Transporte. Por exemplo: freqüências dos canais, detalhes sobre os transponders de satélites, características de modulação, redes alternativas disponíveis, etc. Essas informações são definidas pelo provedor do serviço;

- SDT (Service Description Table): Descreve os serviços do sistema, como: nome do serviço, nome do provedor de serviços e outros parâmetros associados a cada serviço de um mesmo multiplex;

- EIT (Event Information Table): É utilizada para transmitir informações relativas aos programas em curso ou programas futuros, do Fluxo de Transporte, tais como: denominação, hora de início, duração, etc;

- TDT (Time and Date Table): Fornece informações relativas a hora e data do momento, e é utilizada para definir a hora interna do receptor;

- Tabelas Opcionais:

- BAT (Bouquet Association Table): O termo "bouquet" é utilizado referindo-se a uma coleção de serviços comercializados como uma entidade única. A tabela BAT fornece informações sobre os "bouquets", tais como: nome do "bouquet" e a lista de serviços disponíveis em cada "bouquet";

- RST (Running Status Table): Atualiza informações sobre um acontecimento (que está ou não em curso). É transmitida eventualmente e não de forma periódica;

- TOT (Time Offset Table): Fornece informações relativas à data e hora real, assim como à diferença horária local (local time offset);

- ST (Stuffing Tables): Tabelas de enchimento usadas para invalidar tabelas que não são mais úteis. Compartilham os mesmos PID de outras tabelas.

Na tabela 3.7 podem ser observados os valores de PID reservados para as tabelas PSI do MPEG2 System e as tabelas DVB-SI (ISO 13818-1, 1994; EN 300 744, 2004; ETS 300 468, 2004; ARIB STD-10; 2001). 
Multiplexação na infra-estrutura de TV digital

Tabela 3.7 - Alocação de PID para tabelas de serviço (PSI e DVB-SI).

\begin{tabular}{|c|c|c|}
\hline Valor do PID & Nome & Descrição \\
\hline $0 \times 0000$ & PAT & Program Association Table \\
\hline $0 \times 0001$ & CAT & Conditional Access Table \\
\hline $0 \times 0002$ & TSDT & $\begin{array}{l}\text { Transport Stream } \\
\text { Description Table }\end{array}$ \\
\hline $0 \times 0003$ até $0 \times 000 \mathrm{~F}$ & Reservado & - \\
\hline $0 \times 0010$ & NIT, ST & $\begin{array}{c}\text { Network Information Table } \\
\text { Stuffing Table }\end{array}$ \\
\hline $0 \times 0011$ & SDT, BAT, ST & $\begin{array}{c}\text { Service Description Table } \\
\text { Bouquet Association Table } \\
\text { Stuffing Table }\end{array}$ \\
\hline $0 \times 0012$ & EIT, ST & $\begin{array}{c}\text { Event Information Table } \\
\text { Stuffing Table }\end{array}$ \\
\hline $0 \times 0013$ & RST, ST & $\begin{array}{c}\text { Running Status Table } \\
\text { Stuffing Table }\end{array}$ \\
\hline $0 \times 0014$ & TDT, TOT, ST & $\begin{array}{c}\text { Time and Date Table } \\
\text { Time Offset Table } \\
\text { Stuffing Table }\end{array}$ \\
\hline $0 \times 0015$ & Sincronismo da Rede & - \\
\hline $0 \times 0016$ até $0 \times 001 \mathrm{D}$ & Reservado para uso futuro & - \\
\hline $0 \times 001 E$ & DIT & Discontinuity Information Table \\
\hline $0 \times 001 \mathrm{~F}$ & SIT & Selection Informative Table \\
\hline $0 \times 0020$ até $0 \times 002 F$ & $\begin{array}{c}\text { Pode ser usado por } \\
\text { outras Tabelas DVB-SI }\end{array}$ & - \\
\hline $0 \times 0030$ até $0 \times 1 F F E$ & $\begin{array}{c}\text { Pode ser alocada } \\
\text { indiretamente pela PMT }\end{array}$ & - \\
\hline $0 \times 1 F F F$ & $\begin{array}{r}\text { Pacote Vazio } \\
\text { (Null Packet) }\end{array}$ & - \\
\hline
\end{tabular}

A multiplexação de fluxos elementares pode ser feita, associando-se cada um dos PID a um programa MPEG e, conseqüentemente, a um Fluxo de Transporte associado. Em outras palavras, na multiplexação, cada fluxo elementar tem um TS e um PID específicos. Pode-se, portanto, integrar diversas mídias no mesmo meio de transmissão, desde que o multiplexador no transmissor preencha corretamente as tabelas PSI, assim como os pacotes do TS com os dados, vídeo e/ou áudio, associando PID corretamente para cada uma das mídias desejadas.

\subsection{Mecanismos de multiplexação padronizados pelo MPEG2}

Em contraste à seção anterior, que definiu genericamente os fluxos de programa e de transporte e como seria feita a multiplexação, nesta seção são descritos os mecanismos padronizados pelo MPEG2 para a multiplexação de fluxos elementares, ou seja, o MPEG2 System. Assim, o que foi definido de forma intuitiva 
Multiplexação na infra-estrutura de TV digital

é descrito formalmente nesta seção. Além disso, os pacotes, utilizados no Fluxo de Transporte e no Fluxo de Programa, e seus campos são detalhados.

O objetivo do MPEG2 System é detalhar os dois tipos de fluxos de pacotes definidos na seção 3.2: o Fluxo de Programa (PS) e o Fluxo de Transporte (TS). O primeiro (PS) tem o propósito de especificar o armazenamento e a recuperação de informações em DVD, CD, etc, e o último (TS) define uma estrutura de pacotes de tamanho fixo, por onde possam ser transmitidas quaisquer mídias digitais, por exemplo: quadros de vídeo e áudio codificados digitalmente, ou dados de qualquer natureza (texto, imagens, aplicativos, etc).

\subsubsection{MPEG2 Transport Stream (MPEG2 TS)}

O Fluxo de Transporte, padronizado pela $\mathrm{ISO}^{27}$, é denominado MPEG2 Transport Stream ou MPEG2 TS (ISO 13818-1, 1994). O MPEG2 TS descreve os mecanismos necessários para implementar o Fluxo de Transporte e, em última análise, a multiplexação de diversos fluxos elementares no mesmo meio de transmissão.

Conforme descrito anteriormente, no MPEG2 TS, é definida a lógica de encapsulamento de mídias digitais em pacotes de tamanho fixo para o transporte em meios de transmissão não confiáveis, ou seja, para transmissão, por exemplo, através da interface aérea por radiodifusão (RF). Esses pacotes são devidamente identificados para serem corretamente reorganizados no receptor.

O MPEG2 TS é comumente referido como um fluxo de pacotes TS. Assim, o Fluxo de Transporte é formado por uma seqüência de pacotes com mesma estrutura (cabeçalho e campo de dados) transmitidos em um meio físico comum. Cada MPEG2 TS possui um identificador de fluxo (transport_stream_id ${ }^{28}$ ) que o diferencia dos demais, para que seja possível a transmissão de diversos TS no mesmo meio.

\footnotetext{
${ }^{27}$ ISO, do inglês, International Standardization Organization.

${ }^{28}$ Campo da Tabela PAT (Program Association Table) definido pelo MPEG2 para identificar de forma única um TS dentro de uma estrutura multi-fluxos. As tabelas de referência do MPEG2 foram detalhadas na seção 3.1 .
} 
Multiplexação na infra-estrutura de TV digital

Na figura 3.6, são apresentados o pacote TS e seus campos. Na apresentação, verifica-se que cada pacote possui seu identificador de pacote (PID, Packet Identifier), campo que tem como objetivo distinguir cada pacote por seu conteúdo, por exemplo: um conjunto de pacotes com o mesmo PID pode transportar os quadros de um vídeo específico de um determinado canal de TV, enquanto outro PID transportaria as legendas desse mesmo vídeo.

Uma breve descrição de cada um dos campos do pacote TS é apresentada abaixo (HASKELL ET AL, 1997):

- Byte de Sincronismo (Sync, 8 bits): Byte que marca o começo do pacote e tem como função fornecer um marco para sincronização do receptor. Tem como valor sempre 0x47 (0100 0111);

- Flags:

o transport_error_indicator (1 bit): Indica erros no transporte;

o payload_unit_start_indicator - PUSI (1 bit): Indica o início de um pacote encapsulado no campo de dados do pacote TS, por exemplo, o início de um pacote PES;

- transport_priority (1 bit): Indica prioridade do pacote;

- Packet Identifier - PID (13 bits): Utilizado para identificar o fluxo ao qual o pacote pertence. Permite ao receptor diferenciar os pacotes e assim reunir todos os pacotes de um mesmo fluxo elementar (ES, Elementary Stream) ou fluxo elementar empacotado (PES, Packetized Elementary Stream);

- Transport_scrambling_control (2 bits): Bits que indicam quando os procedimentos de acesso condicional foram aplicados pelo transmissor para embaralhar as informações no campo de dados (scrambling control);

- Adaptation_field_control (2 bits): Controla a presença ou não do campo de adaptação ${ }^{29}$ no início do campo de dados, pode ter os seguintes valores: 01 , sem campo de adaptação, somente dados; 10, somente campo de

\footnotetext{
${ }^{29}$ O Campo de adaptação é uma extensão do cabeçalho do pacote TS utilizada para transportar informações adicionais, tais como amostras do PCR (Program Clock Reference), bytes de enchimento para preencher pacotes vazios ou incompletos, etc.
} 
adaptação, sem dados; 11, campo de adaptação, seguido de dados; e 00, reservado para uso futuro;

- Continuity_counter(4 bits): Final do cabeçalho;

- Campo de dados (184 bytes): Dados transportados pelo pacote, ou seja, vídeo, áudio, ou tabelas PSI e DVB-SI.

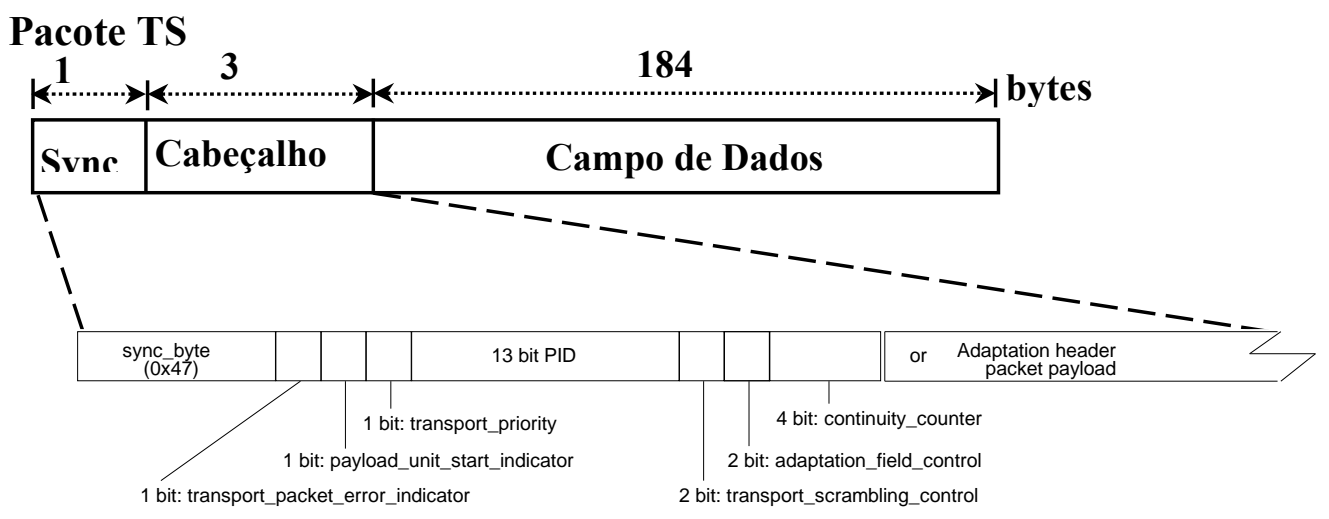

Figura 3.6 - Pacote TS e seus campos.

Cada categoria de conteúdo que pode ser transportada em um pacote TS foi associada a um identificador diferente, padronizado pelo MPEG2 System, denominado stream_type ${ }^{30}$. Para referência, todos os valores possíveis para o stream_type foram reunidos na tabela 3.8. O stream_type é transportado pela tabela PMT, por onde são enviadas as categorias de conteúdo identificadas por um PID específico. São definidas categorias de informação diferentes, de acordo com cada stream_type, o qual pode referir-se a um Fluxo Elementar (ES) ou a um Fluxo Elementar Empacotado (PES). Nota-se que um pacote TS pode encapsular fluxos elementares codificados em MPEG1 (ISO 11172 Video), MPEG2 (ISO 13818-2) e MPEG4 (ISO 14496-2). O MPEG2 TS é de fato utilizado pelos três principais sistemas de TVD-T (ISDB-T, DVB-T e ATSC), sendo usado independentemente da codificação utilizada.

\footnotetext{
${ }^{30}$ Campo da Tabela PMT (Program Map Table) que identifica o tipo de informação contida no pacote TS. As tabelas de referência do MPEG2 foram detalhadas na seção 3.1.
} 
Multiplexação na infra-estrutura de TV digital

Tabela 3.8 - Identificadores de categorias de conteúdo possíveis de serem empacotadas em pacotes TS.

\begin{tabular}{|c|c|}
\hline Stream_type & Descrição \\
\hline $0 \mathrm{x} 00$ & ITU-T | ISO/IEC Reserved \\
\hline $0 \times 01$ & ISO/IEC 11172 Video \\
\hline $0 \times 02$ & $\begin{array}{l}\text { ITU-T Rec. H.262 | ISO/IEC 13818-2 Video or ISO/IEC 11172-2 constrained parameter video } \\
\text { stream }\end{array}$ \\
\hline $0 \mathrm{x} 03$ & ISO/IEC 11172 Audio \\
\hline 0x04 & ISO/IEC 13818-3 Audio \\
\hline $0 \mathrm{x} 05$ & ITU-T Rec. H.222.0 | ISO/IEC 13818-1 private_sections \\
\hline $0 \mathrm{x} 06$ & \begin{tabular}{l|l} 
ITU-T Rec. H.222.0 ISO/IEC 13818-1 PES packets containing private data \\
\end{tabular} \\
\hline 0x07 & ISO/IEC $13522 \mathrm{MHEG}$ \\
\hline $0 \mathrm{x} 08$ & $\begin{array}{l}\text { ITU-T Rec. H.222.0 | ISO/IEC 13818-1 Annex A DSM CC } \\
\end{array}$ \\
\hline 0x09 & ITU-T Rec. H.222.1 \\
\hline 0x0A-0x0D & ISO/IEC 13818-6 (type A-D) \\
\hline $0 \mathrm{x} 0 \mathrm{E}$ & ISO/IEC 13818-1 auxiliary \\
\hline $0 \mathrm{x} 0 \mathrm{~F}$ & ISO/IEC $13818-7$ audio \\
\hline $0 \times 10$ & ISO/IEC 14496-2 video \\
\hline $0 \times 11$ & ISO/IEC 14496-3 audio \\
\hline $0 \times 12$ & ISO/IEC 14496-1 SL-packtized stream or Flexmux stream carried In PES packets \\
\hline $0 \times 13$ & ISO/IEC 14496-1 SL-packtized stream or Flexmux stream carried In ISO/IEC 14496 Sections \\
\hline $0 \times 14$ & ISO/IEC 13818-6 synchronized download protocol \\
\hline $0 \times 15-0 \times 7 \mathrm{~F}$ & ITU-T Rec. H.222.0 | ISO/IEC 13818-1 Reserved \\
\hline $0 \times 80-0 \times F F$ & User Private \\
\hline
\end{tabular}

\subsubsection{MPEG2 Program Stream (MPEG2 PS)}

Os Fluxos Elementares (ES) são informações relacionadas a uma única fonte (vídeo, áudio ou dados), além dos dados para a sincronização básica, e da identificação e características da fonte. No entanto, os ES são componentes básicos do MPEG2 que não podem ser enviados diretamente ao receptor. Por conseguinte, eles devem ser empacotados em pacotes PES (e posteriormente em um pacote TS, caso necessário), ou diretamente em pacotes TS. Esse empacotamento é feito, inserindo essas informações diretamente no campo de dados dos pacotes PES ou pacotes TS. No caso do PES, um quadro inteiro de um fluxo elementar de vídeo pode ser encapsulado. Enquanto em um pacote TS, apenas 184 bytes do quadro podem ser inseridos por pacote.

No pacote PES, informações fundamentais para a correta reconstrução do ES no receptor são enviadas. Abaixo são apresentados os campos do pacote PES e uma breve descrição de cada um deles (HASKELL, 1997): 
- Start_code_prefix (24 bits): 23 bits '0' seguidos de um ' 1 ' ou seja 0x000001 (os start_codes no MPEG tem sempre esse valor seguidos do stream_id);

- Stream_id (8 bits): identifica o tipo de fluxo, tendo valores que variam de 0xBD até 0xFE e indica também se o restante do cabeçalho está presente. É o identificador utilizado para demultiplexar os fluxos elementares de um PS. Seus principais valores são dados na tabela 3.9 abaixo.

Tabela 3.9 - Start codes e stream ids do MPEG2 System.

\begin{tabular}{|c|c|c|}
\hline $\begin{array}{l}\text { start_code ou } \\
\text { stream_id }\end{array}$ & Data ou Stream_type & $\begin{array}{c}\text { Restante do cabeçalho } \\
\text { presente? } \\
\text { (válido para } \\
\text { stream_ids) }\end{array}$ \\
\hline B9 & PS End Code (start_code) & - \\
\hline BA & PS Pack Header (start_code) & - \\
\hline $\mathrm{BB}$ & PS System Header (start_code) & - \\
\hline $\mathrm{BC}$ & PS PMT (start_code) & - \\
\hline $\mathrm{BD}$ & $\begin{array}{l}\text { Private Stream 1 (non MPEG Audio ou } \\
\text { subpictures) }\end{array}$ & Sim \\
\hline $\mathrm{BE}$ & Padding Stream & Não \\
\hline $\mathrm{BF}$ & Private Stream 2 (navigation data) & Não \\
\hline $\mathrm{C} 0$ até $\mathrm{DF}$ & MPEG1/2 Audio Stream & Sim \\
\hline E0 até EF & MPEG1/2 Video Stream & Sim \\
\hline
\end{tabular}

- PES_packet_length (16 bits): Número de bytes que seguem no pacote PES. Para pacotes TS carregando vídeo, o valor ' 0 ' indica tamanho não especificado;

- Marker_bits (2 bits): Geralmente tem valor '10';

- PES_scrambling_control (2 bits): Indica modo de embaralhamento do pacote;

- PES_priority (1 bit): Indica prioridade do pacote (1, prioridade alta);

- Data_alignment_indicator (1 bit): Valor ' 1 ' indica que o campo de dados inicia com um start_code de vídeo ou um sync_word de áudio; 
- Copyright (1 bit): Indica se os dados no pacote PES têm direitos autorais reservados;

- Original_or_copy (1 bit): '1' indica que os dados são originais;

- Flags (8 bits):

O PTS_DTS_flag (2 bits): Valores '10' e ' 11 ' indicam que o PTS está presente, ' 11 ' indica que o DTS está presente e ' 00 ' indica que nenhum dos dois está presente;

○ ESCR_flag (1 bit): Indica que a referência de clock (ESCR) está presente no cabeçalho do pacote PES;

O ES_rate_flag (1 bit): Indica que o valor da taxa de bits do pacote PES está presente no seu cabeçalho;

O DSM_trick_mode_flag (1 bit): Indica que o campo do trick mode está presente no cabeçalho;

- Additional_copy_info_flag (1 bit): Indica presença de informações de copyright no cabeçalho do pacote PES;

O PES_CRC_flag (1 bit): Indica que o campo de checagem de redundância cíclica $(\mathrm{CRC})$ está presente no pacote PES;

O PES_extension_flag (1 bit): Indica uma extensão no cabeçalho do pacote PES;

- PES_header_data_length (8 bits): Especifica o número total de bytes que seguem nos campos opcionais (indicados pelos flags acima), mais os bytes de enchimento, sem contar o campo de dados;

- PTS (Presentation Time Stamp, 40 bits com marcadores): Instante de tempo para a apresentação da mídia. Utiliza um clock de 90KHz (SCR / 300);

- DTS (Decoding Time Stamp, 40 bits com marcadores): Instante de tempo para a decodificação da mídia. Utiliza um clock de 90KHz (SCR / 300);

- ESCR (Elementary Streams clock reference, 48 bits com marcadores): referência de tempo para pacotes PES;

- ES_rate (Elementary Stream Rate, 24 bits com marcadores): Taxa de bits de um fluxo de pacotes PES em múltiplos de 50bytes/segundo. Os campos 
Multiplexação na infra-estrutura de TV digital

ESCR e ES_rate são utilizados apenas quando os pacotes PES são enviados diretamente (PES Stream);

- Trick_mode_control (No. de bits variável): Indica que o trick mode está aplicado ao vídeo (fast forward, rewind, pause, etc);

- Additional_copy_info(8 bits com marcadores): Dados privados para informações de copyright;

- Previous_PES_packet_CRC (16 bits): CRC do cabeçalho do pacote anterior;

- Extension_data (No. de bits variável): Pode conter tamanho de buffers, seqüência de contadores; taxas de bits, etc;

- Stuffing_data (até 32 bytes): Bytes de valor 0xFF até o máximo de 32 bytes;

- PES_packet_data (No. de bits variável): Bytes dos Elementary Streams.

É importante destacar que os campos PTS e DTS dos pacotes PES são utilizados pelo receptor para reproduzir o vídeo ou áudio enviado nos pacotes PES. Eles são os instantes de tempo para apresentação (PTS) e decodificação (DTS) do vídeo ou áudio. São utilizados pelo receptor para que a decodificação e a apresentação dos quadros de vídeo ou áudio sejam feitas nos instantes corretos, de forma que o sincronismo seja preservado e, conseqüentemente, que a percepção de qualidade visual e auditiva por parte do espectador não seja prejudicada.

Quando os pacotes PES são agrupados, empacotados na estrutura do PS e transmitidos diretamente no meio físico, denominamos o fluxo resultante Fluxo de Programa (PS), que também é uma opção de multiplexação. Entretanto, os pacotes PES podem ter tamanhos variáveis, chegando no máximo a 64 kbytes, por isso o Fluxo de Programa é geralmente utilizado para a transmissão em meios confiáveis, por exemplo, na reprodução de um DVD. 


\subsubsection{Utilização do MPEG2 TS e do MPEG2 PS}

Segundo Tryfonas (TRYFONAS, 1999), duas são as razões principais para a utilização do Fluxo de Programa somente em meios razoavelmente livres de erros e com pouco ruído. A primeira é que o PS consiste em pacotes relativamente longos (vários kilobytes), portanto a corrupção ou perda de um pacote pode levar a perda de um quadro de vídeo inteiro e, assim, comprometer a exibição no receptor. A segunda é que devido ao fato de os pacotes do PS terem tamanhos variáveis, é difícil para o decodificador prever o início e o fim dos vários pacotes. Sendo assim, o decodificador deve confiar no campo de comprimento do pacote (PES_Packet_Length) que consta no seu cabeçalho. Se esse valor for corrompido na transmissão, a perda de sincronismo pode ocorrer no receptor.

No Fluxo de Transporte, por sua vez, os problemas apontados acima dificilmente ocorrem, pois os pacotes têm tamanho fixo, sendo que a detecção do início e do fim de cada pacote é mais simples e, assim, o sincronismo pode ser mantido com mais facilidade. Geralmente, os pacotes são protegidos ainda por mecanismos de controle de erros, como a codificação Reed-Solomon (ISO 13818-1, 1994).

O PES é fundamental para que o receptor obtenha informações tais como: dados de sincronismo (PTS/DTS), estrutura da checagem de redundância cíclica (CRC), indicadores de embaralhamento do campo de dados do pacote, copyright, etc. Uma vez preenchidos, os pacotes PES podem ser inseridos no campo de dados dos pacotes TS para transmissão ao receptor. O encapsulamento do PES no pacote TS pode ser feito de várias formas, por exemplo: um único pacote PES é encapsulado em cada pacote TS (caso o pacote PES tenha tamanho menor que 184 bytes) ou cada pacote PES é dividido em vários pacotes TS. Em ambos os casos, o primeiro pacote TS que contenha o início de um pacote PES deve ter o flag payload_unit_start_indicator ${ }^{31}$ com valor ' 1 ', os demais pacotes devem ter esse flag

\footnotetext{
${ }^{31}$ Campo do cabeçalho do pacote TS.
} 
com valor ' 0 '. O flag payload_unit_start_indicator indicará que o primeiro byte do campo de dados do pacote TS corresponde ao primeiro byte do pacote PES.

Conforme descrito na seção 3.1, uma seqüência de pacotes PES, acrescidos de Pack Headers, forma um fluxo de programa. Nesse caso, os fluxos elementares não são encapsulados em pacotes TS e sim, diretamente multiplexados através de pacotes PES.

Por outro lado, os fluxos elementares de cada programa podem ser encapsulados diretamente em pacotes TS e transmitidos ao receptor. Nesse caso, no entanto, na demultiplexação, várias informações de sincronismo importantes, tais como ESCR, ES_rate, PTS e DTS, não estariam disponíveis ao receptor e a apresentação ao usuário poderia ser prejudicada. Sendo assim, na grande maioria das aplicações, utiliza-se o pacote PES como base para a criação de fluxos multiplexados, como é possível verificar na figura 3.2. Cada fluxo de transporte, por conseguinte, é preenchido pelos bytes de pacotes PES de cada um dos fluxos elementares. 
Mecanismos de sincronização do MPEG2 System

\section{MECANISMOS DE SINCRONIZAÇÃO DO MPEG2 SYSTEM}

Neste capítulo são descritos os mecanismos adotados pelo MPEG2 System para assegurar o sincronismo de mídias desde o emissor (codificação) até o receptor (decodificação e apresentação ao usuário final). São discutidos os processos de geração de amostras do relógio do sistema, e sua reconstrução no receptor, assim como a geração dos tempos de apresentação e decodificação de mídias. Além disso, métodos para manter o relógio do receptor sincronizado com o do emissor e métodos para ressincronizar o fluxo de transporte são apresentados.

A sincronização das mídias no receptor é fundamental para a qualidade da exibição dos canais transmitidos. Cada programa na TV digital tem sua base de tempo, ou seja, cada programa tem seu relógio, que é comum a todos os fluxos elementares que o constituem. A decodificação e a apresentação das mídias segue uma temporização definida pelo transmissor. O transmissor, por sua vez, tem como referência o relógio do sistema, sendo, portanto, muito importante garantir que o receptor reconstrua esse relógio corretamente, utilizando as informações contidas nos pacotes dos fluxos multiplexados (PS ou TS) e mantendo o sincronismo em relação ao transmissor.

Por esse motivo, a especificação do MPEG2 System define um modelo de temporização, onde o atraso fim a fim, desde o sinal de entrada no codificador até o sinal de saída no decodificador, é constante para vídeos e áudio. Esse atraso é a soma dos tempos de codificação, buferização no codificador, multiplexação, transmissão ou armazenagem, demultiplexação, buferização no decodificador, decodificação e apresentação. Na codificação dos fluxos multiplexados, são incluídas informações de tempo utilizadas para implementar sistemas que possuem esse comportamento (atraso fim a fim constante). Todas as informações de temporização são definidas em relação a um relógio de sistema comum ao emissor e ao receptor.

Nas próximas seções, são descritos, em mais detalhes, o modelo de temporização e sincronismo do MPEG2 System e sua utilização para reconstruir o relógio do sistema e sincronizar mídias no receptor. 
Mecanismos de sincronização do MPEG2 System

\subsection{Modelo de Temporização do MPEG2 System}

Nesta seção, são apresentados o modelo de temporização do MPEG2 System e os elementos que possibilitam ao receptor manter o sincronismo dos fluxos elementares.

Alguns parâmetros são essenciais no modelo de temporização do MPEG2 System: as amostras do relógio do sistema, denominadas PCR (Program Clock Reference) ou SCR (System Clock Reference); e os tempos de apresentação e decodificação das mídias, denominados PTS (Presentation Time Stamp) e DTS (Decoding Time Stamp), respectivamente.

Esses parâmetros são inseridos em campos da estrutura de pacotes da camada de sistema (o PCR, no campo de adaptação dos pacotes TS; o SCR, no Pack Header do PS; e o PTS e o DTS, no cabeçalho dos pacotes PES) para auxiliar o receptor em sua tarefa de garantir o sincronismo, seguindo um modelo teórico definido na especificação do MPEG2 System. Nas seções a seguir, os parâmetros apresentados acima são detalhados, assim como o é o modelo teórico de temporização.

O MPEG2 System define um modelo de temporização em que todos os quadros de vídeo e amostras de áudio enviados ao codificador do emissor são apresentados uma única vez, após um atraso constante, na saída do decodificador do receptor. Nesse modelo, as taxas de amostragem, tanto para o vídeo como para o áudio, são precisamente as mesmas no emissor e no receptor. Para ilustrar o modelo de temporização do MPEG2 System, na figura 4.1 é apresentado um diagrama de blocos com seus principais elementos funcionais. 
Mecanismos de sincronização do MPEG2 System

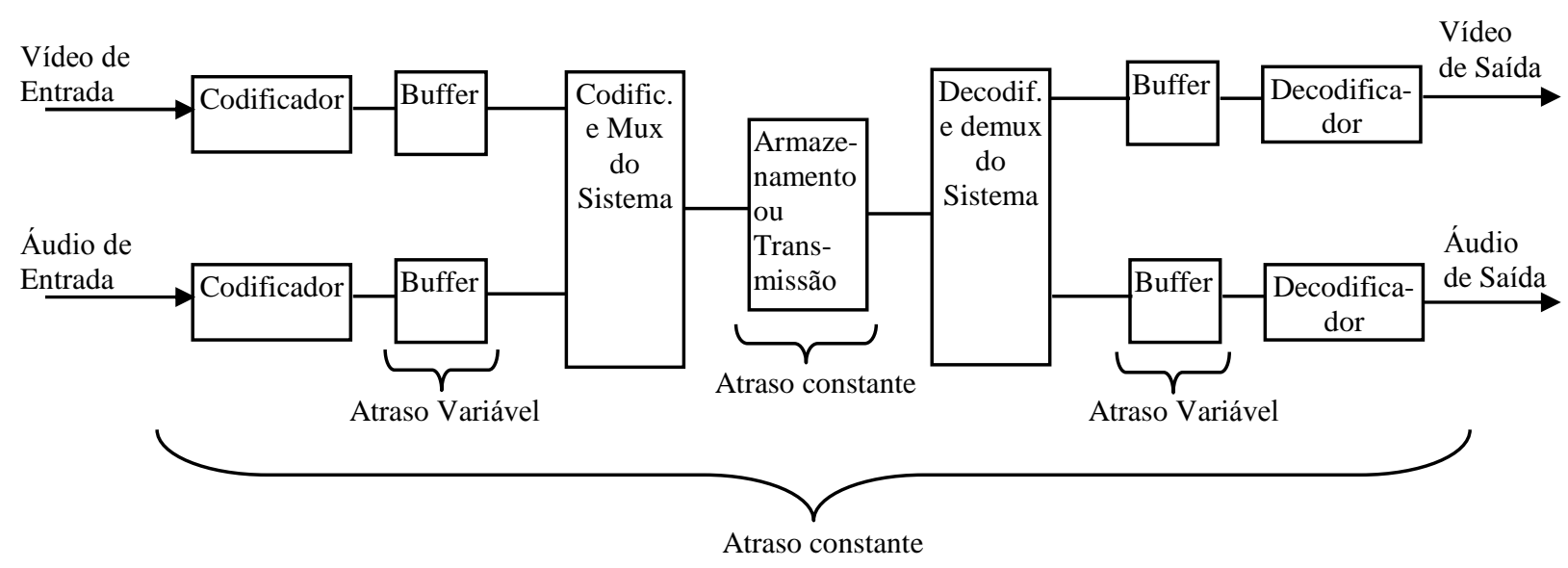

Figura 4.1 - Modelo de temporização para atraso fim a fim constante (ISO

13818-1, 1994).

Na figura 4.1, nota-se que o modelo se baseia num atraso fim a fim constante, apesar dos atrasos variáveis nos buffers do emissor e do receptor. Segundo o modelo, para manter o atraso fim a fim constante, os atrasos variáveis são especificados. $\mathrm{O}$ atraso na transmissão ou armazenamento é considerado constante, mas, na prática, alguma variação de atraso pode ocorrer e, portanto, deve ser compensada por algum mecanismo no receptor.

Os atrasos nos buffers para vídeo e áudio são diferentes, pois sua codificação é efetuada de maneira bastante distinta. Como as mídias devem ser apresentadas em sincronia, os atrasos nos buffers de decodificação do receptor devem ser especificados, de forma a garantir a apresentação simultânea de vídeo e aúdio. Esses atrasos são calculados no emissor e enviados ao receptor através de campos específicos dos fluxos multiplexados.

Para assegurar atrasos fim a fim constantes, o modelo tem um relógio comum ao emissor e receptor, denominado STC (System Time Clock), que é gerado no emissor. A partir desse relógio, são criados os registros de tempo (time stamps) que indicam os instantes corretos para a decodificação e apresentação do vídeo e áudio. Dessa forma, são especificados os atrasos variáveis nos buffers do receptor. No emissor são geradas também amostras do STC em períodos regulares, originando, assim, valores instantâneos do relógio.

Conforme dito anteriormente, o tempo de apresentação é denominado PTS (Presentation Time Stamp); o tempo de decodificação é chamado DTS (Decoding 
Mecanismos de sincronização do MPEG2 System

Time Stamp); e os valores instantâneos do relógio são referidos por SCR (System Clock Reference) para o Fluxo de Programa e PCR (Program Clock Reference) para o Fluxo de Transporte.

No capítulo 3, a estrutura de pacotes do MPEG2 System foi apresentada. Nela, é possível verificar que PTS, DTS e SCR são campos do cabeçalho dos pacotes PES (PTS e DTS) e dos pacotes PS (SCR) e que o PCR, por sua vez, é enviado pelo fluxo de transporte no campo de adaptação dos pacotes TS.

Os parâmetros acima devem ser devidamente especificados de forma que: vídeo e áudio sejam precisamente sincronizados na apresentação ao usuário, e os buffers no receptor não transbordem (overflow). Para o receptor definir os atrasos corretos nos buffers (PTS e DTS) e tornar o atraso do sistema, como um todo, constante, o passo do relógio no receptor deve ser bastante próximo daquele no emissor. Por isso, o relógio é reconstruído no receptor por meio de amostras do relógio do emissor, ou seja, amostras do SCR ou PCR.

O PTS e o DTS são definidos para cada fluxo elementar, embora não sejam definidos para todas as unidades de acesso (quadros ou amostras de vídeo ou áudio codificados). O decodificador pode, no entanto, fazer uma interpolação para valores não definidos. Esses registros de tempo devem ser enviados em intervalos de até 700ms, sendo o tempo, entre duas amostras de PTS ou DTS, medido em termos do tempo de apresentação e não pelos instantes em que as amostras foram transmitidas e recebidas. Ou seja, é utilizada a mesma base de tempo em que foram definidos os valores do PTS ou do DTS para definir o intervalo entre amostras. Isso se deve ao fato de a distância entre amostras do PCR ou SCR ser utilizada para calcular as taxas de escrita e leitura nos buffers do decodificador.

O par PTS/DTS não define sozinho o correto preenchimento dos buffers do decodificador. Os valores do PTS e DTS apenas indicam o atraso que deve ser considerado entre o recebimento dos primeiros bits do fluxo elementar e o momento em que deve ser iniciada a apresentação, definindo a quantidade de tempo que dados codificados devem permanecer nos buffers de decodificação e apresentação. A informação a respeito dos buffers só pode ser definida com os dois campos em conjunto, PTS e DTS, e com a correta reconstrução do relógio no receptor. Portanto, o comportamento dos buffers deve ser determinado pelos 
valores do PCR/SCR, pelos instantes em que essas amostras são recebidas, e pelos valores do PTS/DTS.

O PCR é calculado por meio da amostragem do relógio do sistema. Para isso, na especificação do MPEG2 System, são definidos limites para a freqüência do relógio do sistema, denominada system_clock_frequency, que deve ser estritamente gerada dentro do seguinte intervalo:

$27000000-810 \mathrm{~Hz} \leq$ system_clock_frequency $\leq 27000000+810 \mathrm{~Hz}$;

sendo a taxa de mudança do system_clock_frequency com o tempo $\leq 75 \mathrm{x}$ $10^{-3} \mathrm{~Hz} / \mathrm{s}$

Consideradas as restrições acima, o PCR pode ser calculado por meio da combinação da freqüência do relógio do sistema (system_clock_frequency) com o instante em que o i-ésimo byte do fluxo de transporte entra no decodificador do receptor, $\mathrm{t}(\mathrm{i})$.

A equação 4.1, abaixo, apresenta como calcular os valores do PCR. Os termos da equação 4.1, program_clock_reference_base (PCR_base) e program_clock_reference_ext (PCR_Ext), são ambos transmitidos no campo de adaptação dos pacotes TS que contém amostras do PCR. Na figura 4.2, a estrutura do campo de adaptação contendo uma amostra de PCR é mostrada. Nota-se a presença dos dois campos, PCR_base de 33 bits e PCR_ext de 9 bits.

Ou seja, o valor dos PCR é calculado por:

PCR(i) = PCR_base $(i) \times 300+$ PCR_ext(i)

Onde:

i é o índice do byte contendo o último bit do respectivo PCR. 


\section{Pacote TS com uma amostra de PCR}

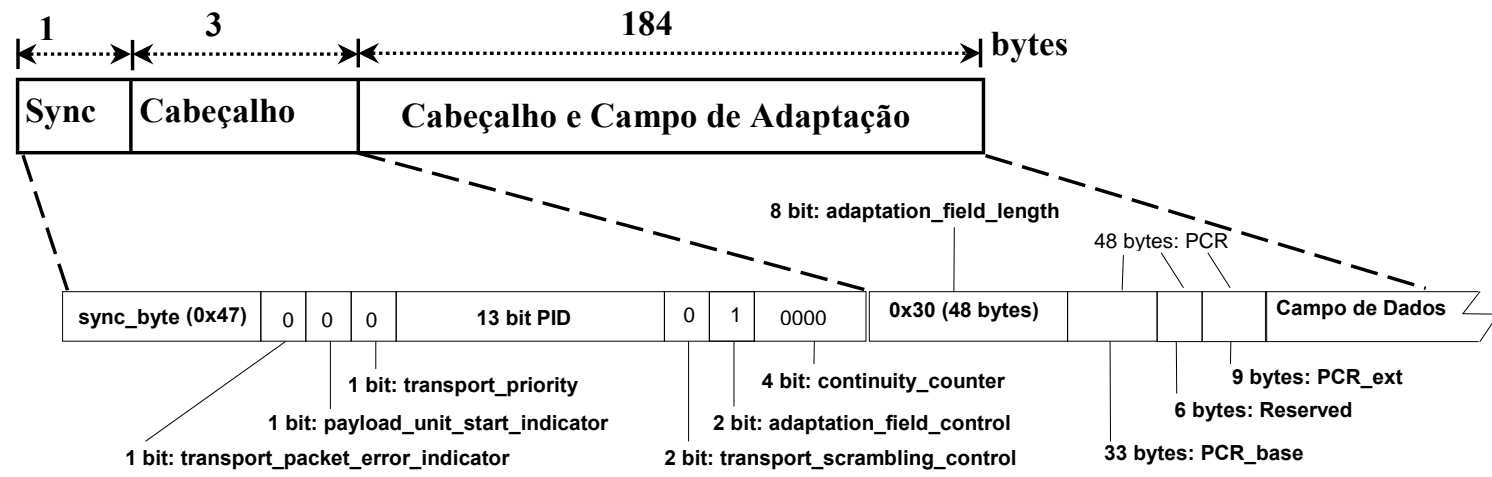

Figura 4.2 - Estrutura do campo de adaptação contendo uma amostra de PCR.

O instante de tempo até o qual um determinado byte deve chegar ao decodificador, no receptor, t(i), pode ser calculado como na expressão 4.3. Ou seja, pode-se obter $\mathrm{t}(\mathrm{i})$ por meio da amostra mais recente do PCR e da taxa de bits do fluxo de transporte (transport_rate). O transport_rate, por sua vez, é calculado pela razão do número de bytes entre as duas últimas amostras do PCR e a diferença entre os valores dessas duas últimas amostras. A expressão para o cálculo do transport_rate é apresentada em 4.5.

O instante de tempo t(i) é dado por:

$t(i)=[\operatorname{PCR}(i ”) /$ system_clock_frequency $]+\left[(i-i ”) / \operatorname{transport} \_\right.$rate(i) $]$

substituindo-se system_clock_frequency, que deve ser $27.000 .000 \mathrm{~Hz}$, na expressão 4.2 obtém-se:

$\mathrm{t}(\mathrm{i})=[\mathrm{PCR}(\mathrm{i} ") / 27.000 .000]+[(\mathrm{i}-\mathrm{i}$ ") $) /$ transport_rate(i) $]$

Onde:

i' é o índice do byte contendo o último bit da penúltima amostra do PCR;

i" é o índice do byte contendo o último bit da última amostra do PCR;

i é o índice de um byte qualquer do fluxo de transporte entre i' e i"; e

PCR(i”) é o valor mais recente do PCR. 
Sendo que o transport_rate é dado por:

transport_rate(i) $=\left[\left(\mathrm{i}-\mathrm{i}^{\prime \prime}\right) \mathrm{x}\right.$ system_clock_frequency ] / [ PCR(i')-PCR(i”) ]

Substituindo-se system_clock_frequency, que deve ser $27.000 .000 \mathrm{~Hz}$, na expressão 4.4 resulta em:

transport_rate(i) $=\left[\left(\mathrm{i}-\mathrm{i}{ }^{\prime \prime}\right) \times 27.000 .000\right] /\left[\operatorname{PCR}\left(\mathrm{i}{ }^{\prime}\right)-\operatorname{PCR}\left(\mathrm{i}^{\prime \prime}\right)\right]$

Onde:

i' é o índice do byte contendo o último bit da penúltima amostra do PCR;

i" é o índice do byte contendo o último bit da última amostra do PCR;

i é o índice de um byte qualquer do fluxo de transporte entre i' e i”;

i-i" é o número de bytes entre i e i”, ou seja, a distância em bytes entre o byte i e a última amostra do PCR. Para fins dessa dissertação, essa métrica é denominada delta_bytes;

PCR(i”) é o valor mais recente do PCR, expresso em número de transições de um relógio de $27 \mathrm{MHz}$;

PCR(i') é o valor do PCR imediatamente anterior a PCR(i”), expresso em número de transições de um relógio de $27 \mathrm{MHz}$;

[PCR(i')-PCR(i”)] é a diferença entre as duas últimas amostras do PCR, expresso em número de transições de um relógio de $27 \mathrm{MHz}$; e

[PCR(i')-PCR(i”)]/27.000.000 é a expressão que calcula a diferença em segundos entre as duas últimas amostras do PCR. Para fins dessa dissertação, essa métrica é denominada delta_tpcr.

Substituindo-se delta_bytes e delta_tpcr na expressão 4.5, obtém-se como resultado:

transport_rate $=$ delta_bytes $/$ delta_tpcr 
Mecanismos de sincronização do MPEG2 System

Outras métricas importantes devem também ser definidas no âmbito dessa dissertação (Tektronics, 2006):

- delta_t: é a diferença, em segundos, entre o instante de chegada do pacote TS que contém a última amostra do PCR e o instante de chegada do pacote TS que contém a penúltima amostra do PCR. Ou seja, é diferença efetiva, em segundos, entre as duas últimas amostras do PCR;

- delta_tb: é a diferença, em segundos, entre as duas últimas amostras do PCR, calculada utilizando-se a expressão 4.6, sendo delta_tper substituído por delta_tb na expressão. Mede discrepâncias na geração da amostra do PCR (desconsiderados os efeitos da rede de transporte); e

- PCR_Jitter: é a diferença entre delta_tpcre delta_t. Mede a variação de atraso das amostras do PCR, pois delta_tpcr é o valor especificado pelo modelo de temporização do MPEG2 System, ou seja, o valor para a correta sincronização do fluxo de transporte, e delta_t é o valor efetivamente obtido.

A tolerância de variação do PCR é de \pm 500 ns, sendo definida como o valor máximo de discrepância no valor do PCR. Entretanto, essa tolerância não inclui erros ou atrasos nos pacotes devido a variações de atraso na rede, o que pode se tornar um problema para a reconstrução do relógio no receptor.

A localização das amostras do PCR no fluxo de transporte é muito importante e recomenda-se manter constante a distância relativa entre duas amostras consecutivas. O deslocamento das amostras do PCR dentro do fluxo de transporte modifica a taxa de decodificação dos bytes dos fluxos elementares no receptor, pois se altera o valor do transport_rate e do tempo de chegada ao decodificador t(i), como pode ser verificado nas expressões 4.3 e 4.5 .

Nota-se também que entre duas amostras consecutivas do PCR, o transport_rate é mantido constante, por isso a taxa do fluxo de transporte é denominada constante em partes (piecewise constant rate). Em outras palavras, pode-se modificar a taxa no decodificador através do deslocamento das amostras do PCR no Fluxo de Transporte. Esse mecanismo é bastante útil quando são feitas intervenções no Fluxo de Transporte: remultiplexações devido a mudança das taxas de alguns fluxos elementares (mudança da codificação de vídeo ou aúdio) ou retirada 
de algum fluxo elementar do Fluxo de Transporte em algum nó da rede, por exemplo, em uma rede de TV a cabo entregando um canal pay-per-view a um assinante específico.

O PCR e o SCR devem ser recebidos a cada $100 \mathrm{~ms}$ e $700 \mathrm{~ms}$, respectivamente. O PCR fornece referências do relógio para cada programa $\mathrm{MPEG}^{32}$ e o SCR indica o valor correto do STC quando o SCR é recebido no decodificador. O PCR e o SCR podem ser interpretados como o instante de tempo em que PCR ou SCR devem chegar ao decodificador, supondo que o STC, no receptor, está sincronizado com o emissor.

A interpretação de cada amostra do PCR ou do SCR depende da aplicação. No caso dos fluxos multiplexados serem entregues para vários decodificadores simultaneamente, não se pode garantir que o PCR ou o SCR cheguem ao mesmo tempo a todos eles. Portanto, o relógio do emissor deve ser reconstruído a partir dos valores do SCR ou PCR, em cada receptor, para sincronizá-los com o emissor. Em grande parte das aplicações, O SCR, assim como o PCR, é visto, como amostra do STC.

Sendo a freqüência do relógio, no receptor, idêntica à do emissor, as taxas de decodificação e apresentação dos fluxos elementares, no receptor, serão as mesmas do emissor, e assim o atraso fim a fim será constante. No entanto, na prática os relógios não seguem estritamente esse comportamento, ou seja, o relógio no receptor não é o mesmo que aquele indicado pelos PCR/SCR. Nesse contexto, o receptor deve reconstruir o relógio do emissor de forma a sincronizar os relógios em ambos os extremos da comunicação. Os processos utilizados para reconstruir o relógio do emissor no receptor são apresentados na seção 4.2.

\footnotetext{
${ }^{32}$ Como definido no capítulo 2, um programa MPEG é um conjunto de fluxos elementares com uma base de tempo comum, que devem ser apresentados de forma sincronizada.
} 


\subsection{Sincronização no Receptor de acordo com o MPEG2 System}

Nesta seção são detalhados os métodos implementados no receptor, em hardware ou software, para garantir o sincronismo das mídias transportadas pelos fluxos multiplexados. Nesses métodos, são utilizados os elementos descritos na seção 4.1, padronizados pelo MPEG2 System, sendo que os seguintes processos podem ser destacados: a reconstrução do relógio do sistema, correção do relógio na presença de variação de atraso nos pacotes do fluxo multiplexado e a utilização dos tempos de apresentação e decodificação.

A unidade receptora e decodificadora (URD) deve implementar determinadas funções, com o objetivo de apresentar os fluxos elementares selecionados pelo usuário. Cada uma delas tem fundamental importância para as aplicações da TV digital, que são executadas acima das camadas de transporte, multiplexação e codificação. A figura 4.3 mostra um diagrama de blocos que indica as principais funções para a recepção do fluxo de transporte, demultiplexação e decodificação dos fluxos elementares.

Observa-se que o controle do relógio na URD só pode ser efetuado, se na demultiplexação do fluxo de transporte, as informações de sincronismo forem corretamente extraídas. Nota-se também que os processos de decodificação dependem do controle do relógio e, conseqüentemente, a apresentação dos fluxos elementares também depende. 


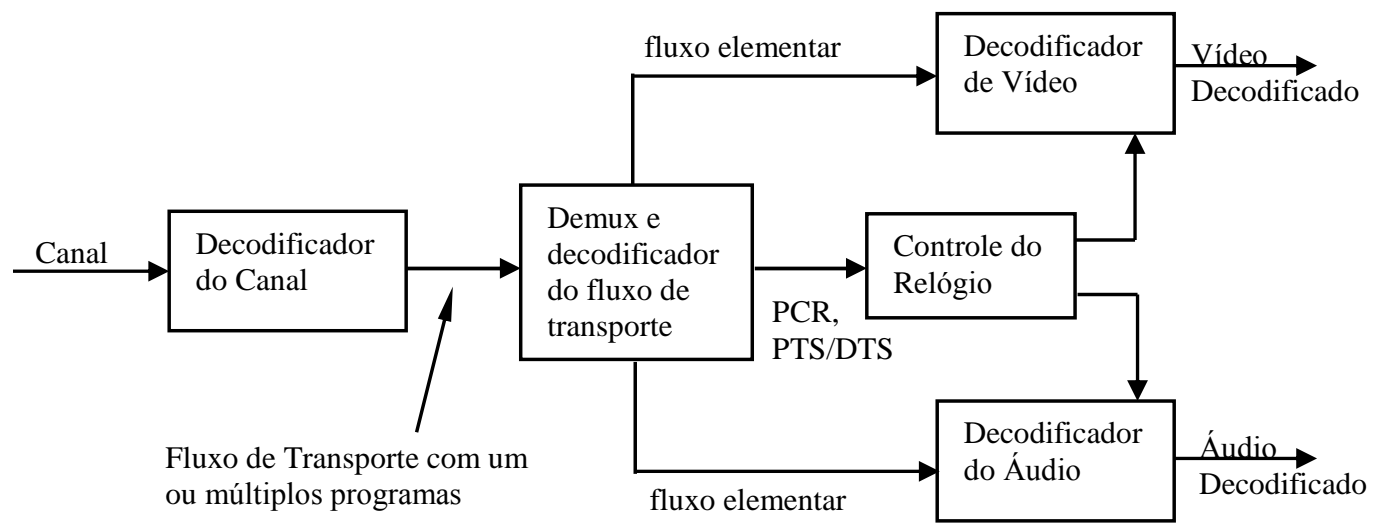

Figura 4.3 - Diagrama de Blocos das principais atividades da URD (ISO 138181, 1994).

Como apresentado na seção 4.1, o fluxo de transporte carrega as amostras do relógio do transmissor (PCR) no campo de adaptação dos pacotes TS. Os tempos de apresentação (PTS) e de decodificação (DTS) são transportados, no cabeçalho dos pacotes PES, encapsulados nos pacotes TS. O PTS e o DTS são determinados, usando como referência o relógio do emissor e, portanto, a reconstrução do relógio no receptor deve gerar um sinal tão próximo quanto possível daquele gerado no emissor.

O PCR é enviado periodicamente no fluxo de transporte, sendo a distância entre dois pacotes contendo amostras do PCR controlada, de forma que essas amostras estejam dispostas em intervalos regulares. As amostras do PCR formam uma linha de tempo para todos os pacotes do fluxo de transporte e, a partir delas, é determinada a taxa de envio de fluxos elementares ao decodificador.

Em outras palavras, a taxa de leitura do buffer de decodificação é calculada a partir das distâncias temporal e espacial (número de bytes) entre amostras do PCR. Ou seja, essa taxa pode ser calculada dividindo-se o número de bytes entre dois pacotes consecutivos, contendo amostras do PCR, pela diferença entre os instantes de chegada das duas amostras. Portanto, caso a variação de atraso das amostras do PCR seja minimizada, a taxa de leitura do buffer de decodificação refletirá exatamente o comportamento especificado pelas amostras do PCR. 
Mecanismos de sincronização do MPEG2 System

Segundo Yu (YU; NAHRSTEDT, 2002), mantendo constante o atraso do fluxo de pacotes, com relação ao receptor, ele será capaz de reconstruir o relógio do emissor sem muitas distorções.

Assim que os fluxos elementares são enviados ao buffer de decodificação, o PTS e o DTS são examinados. O DTS determina o instante em que o decodificador deve retirar os quadros do fluxo elementar do buffer de decodificação ,efetivamente decodificando-os e escrevendo-os no buffer de apresentação. O PTS, por sua vez, indica o momento que os quadros decodificados devem ser retirados do buffer de apresentação e enviados às aplicações para sua exibição em dispositivos de entrada e saída (TV, monitor, etc).

O PTS e o DTS são interpretados em relação à linha de tempo determinada pelas amostras do PCR. Nota-se, dessa forma, a importância da estabilidade e precisão do relógio reconstruído a partir do PCR. No entanto, as redes de transporte utilizadas para enviar os pacotes do fluxo multiplexado apresentam atrasos e variação de atraso que podem alterar, sobremaneira, o instante de chegada de cada PCR. Isso pode causar uma grande variação do relógio, no receptor.

Para evitar mudanças bruscas no relógio do receptor e mantê-lo estável, dentro de certos limites, são utilizadas técnicas como o Phase Locked Loop (PLL) (ISO 13818-1, 1994). Esse método utiliza a retroalimentação do relógio reconstruído no receptor, para sintonizar um sinal interno (gerado por um oscilador) por meio do sinal externo de relógio (construído com o PCR) e, assim, gerar um relógio mais estável na presença da variação de atraso.

A estrutura clássica para implementar o PLL (Phased-locked loop) é mostrada na figura 4.4. Sendo que sua operação acontece da seguinte maneira:

- Ao receber uma referência de tempo inicial para um programa, o STC é inicializado com o valor do PCR, ou seja, o PCR é associado diretamente ao contador STC. Assim, o PLL gera um sinal com determinada freqüência na saída;

- Cada novo PCR é comparado com o valor atual do STC, que é gerado por um contador cujo relógio é o sinal de saída. Um valor de erro "e" é calculado; 
Mecanismos de sincronização do MPEG2 System

- O valor do erro é a entrada de um filtro passa-baixas com estágio de ganho, que é projetado para cada aplicação específica. Na saída do filtro, é gerado um sinal "f" que controla a freqüência de um oscilador VCO;

- O VCO (Voltage Clock Oscilator, um oscilador de voltagem) gera um sinal de saída, com freqüência nominal de $27 \mathrm{MHz}$, que é utilizado como relógio no decodificador.

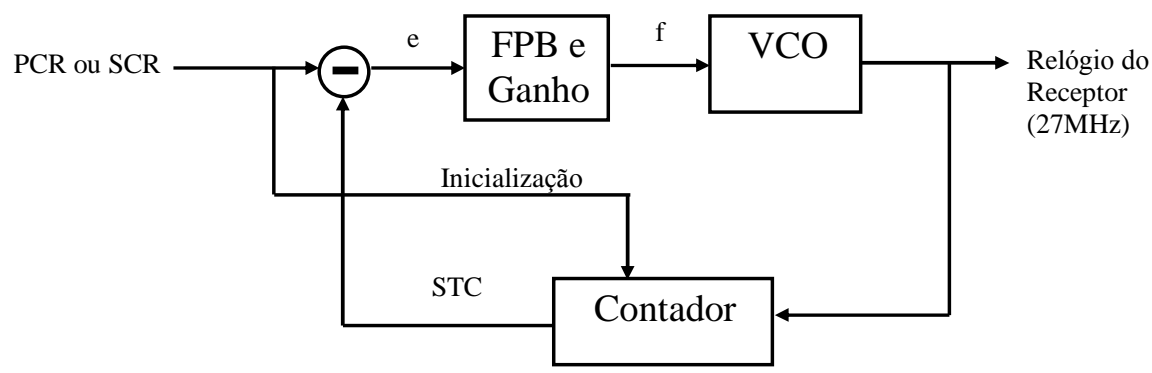

Figura 4.4 - Diagrama de blocos do PLL.

A figura 4.5 apresenta um diagrama que ilustra a geração e extração do PCR e dos PTS e DTS, dos fluxos multiplexados, e a interação entre os elementos no emissor e no receptor (dentre eles o PLL) para manter o sincronismo.

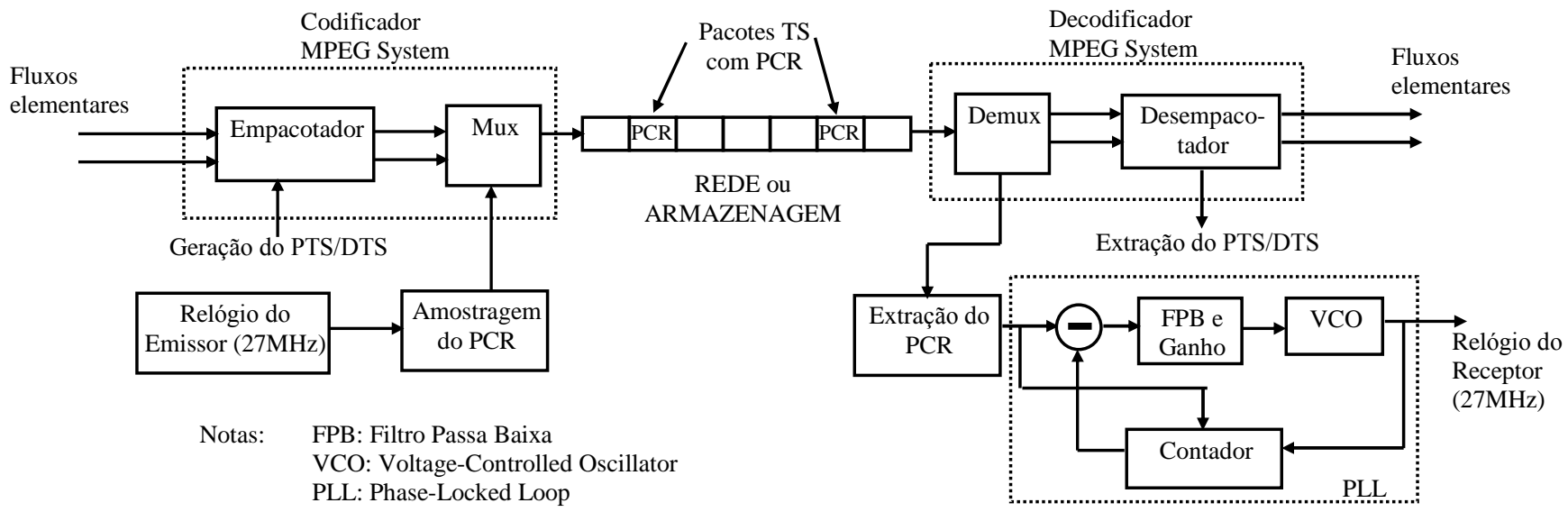

Figura 4.5 - Diagrama que mostra a interação dos elementos do receptor para manter o sincronismo.

O efeito da variação entre a freqüência do STC no emissor e no receptor, caso não se tivesse o PLL, é um gradual e inevitável aumento ou diminuição do 
Mecanismos de sincronização do MPEG2 System

preenchimento do buffer do decodificador, de forma que o transbordo, ou o esvaziamento total, eventualmente ocorreria para buffers de tamanho finito.

O PCR pode sofrer variações de atraso (jitter) indesejáveis quando os Fluxos de Transporte são transmitidos em redes de pacotes ou quando eles passam por processos de remultiplexação, onde podem ocorrer mudanças na ordem e na localização das amostras do PCR dentro do Fluxo de Transporte. A mudança na localização temporal do PCR torna os valores das amostras anteriores do PCR incorretas, pois o tempo que indica um atraso fim a fim constante não está mais refletido nessas amostras. Esse fenômeno provoca uma discrepância entre o valor real do PCR e o valor que ele deveria ter no momento em que foi recebido devido a um atraso ou adiantamento do PCR.

A variação de atraso no PCR causa mudanças no relógio do receptor pois, em um receptor com PLL, amostras do PCR atrasadas ou adiantadas causam erros ("e") que, por sua vez, mudam a freqüência (“f”) do oscilador do relógio , alterando o sinal de saída do PLL. Algumas aplicações não toleram mudanças muito acentuadas no relógio e assim seu desempenho fica comprometido.

Alguns mecanismos para suavizar a variação de atraso nas amostras do PCR são apresentados na seção 4.3 a seguir.

\subsection{Algoritmos de Ressincronização de Mídias}

O objetivo desta seção é descrever, de forma breve, alguns algoritmos essenciais para a ressincronização de mídias inseridas em fluxos de transporte (MPEG2 Transport Stream), ou seja, ressincronização de sinais de TV digital. Na seção 4.3.1 são apresentados algoritmos de ressincronização baseados no re-cálculo das amostras do PCR e na compensação das variações de atraso. A seção 4.3.2 apresenta o algoritmo proposto por Yu (YU; NAHRSTEDT, 2002) para implementar a inserção de pacotes TS, de forma a manter a distância constante entre amostras do PCR. Já a seção 4.3.3 apresenta o algoritmo proposto por Yu (YU; NAHRSTEDT, 2002) que tem o intuito de reposicionar os pacotes TS, quando necessário, para atingir uma nova taxa de bits constante. 
Mecanismos de sincronização do MPEG2 System

Entende-se por ressincronização de mídias em sinais de TV Digital o processo por meio do qual se mantêm a periodicidade e o valor das amostras do relógio do emissor (Program Clock Reference - PCR) o mais fiel possível aos valores originais; utilizando, para isso, processos que atuam no fluxo de transporte para corrigir variações devido a atrasos na rede, etc. Os algoritmos que têm como objetivo ressincronizar as mídias em sinais de TV digital devem, portanto, reposicionar os pacotes que contêm amostras do PCR, de forma que seja constante a distância relativa entre uma dada amostra e a que lhe for imediatamente anterior ou posterior. Além disso, os algoritmos devem adequar os valores de cada amostra para refletir a situação original no emissor.

\subsubsection{Algoritmos de ressincronização baseados no recálculo do PCR e na compensação de variações de atraso}

Vários algoritmos foram propostos, na literatura científica, para implementar a ressincronização de mídias, com o intuito de corrigir os efeitos de atrasos e de remultiplexações no fluxo de transporte. Três métodos principais podem ser utilizados: o reordenamento dos pacotes contendo amostras do relógio (PCR), o recálculo e reposicionamento das amostras do relógio (PCR), e a compensação da variação de atraso. O primeiro é abordado nas seções 4.3.2 e 4.3.3. Os outros dois métodos são descritos nesta seção por meio de algumas implementações propostas (TAKAHASHI ET AL, 2001; BUNGUM, 1996; TRYFONAS; VARMA, 1999a; TRYFONAS; VARMA, 1999b; NORO; HUSBAUX, 1999; TRYFONAS，1999; NORO; 2000).

Os mecanismos baseados no recálculo do PCR (TAKAHASHI ET AL, 2001; BUNGUM, 1996) efetuam a ressincronização por meio da determinação de novas amostras do relógio (PCR). Como são recalculados os valores do PCR, um novo posicionamento dessas amostras dentro do fluxo de transporte torna-se necessário para garantir o novo sincronismo. Os métodos que utilizam essa abordagem são geralmente implementados em hardware, pois precisam gerar novas amostras do PCR, o que depende de osciladores e outros dispositivos (PLL, etc) que são construídos em hardware na grande maioria das implementações.

Os métodos por compensação da variação de atraso reconstroem o relógio do emissor tentando compensar os atrasos inseridos previamente. Esses algoritmos 
Mecanismos de sincronização do MPEG2 System

fazem estimativas da variação de atraso e a utilizam na implementação de filtros para a compensação desses atrasos.

Embora utilizem o mesmo princípio, várias formas de compensar os atrasos são possíveis. Em Noro e Husbaux, e Noro (NORO; HUSBAUX, 1999; NORO, 2000), foi proposto um algoritmo, que utiliza uma regressão linear das amostras do relógio e dos tempos de chegada de cada amostra, para determinar uma função linear que represente o comportamento do relógio na ausência de atrasos. Ou seja, por meio da reta de regressão, o relógio do emissor é reconstruído sem variações de atraso. Outro método, que foi proposto (TRYFONAS; VARMA, 1999a; TRYFONAS; VARMA, 1999b; TRYFONAS, 1999), compensa as variações de atraso, multiplicando as amostras do PCR por fatores de escalonamento proporcionais à diferença de fase entre o relógio reconstruído no receptor e o representado pelo PCR. Ou seja, por meio de um escalonamento adaptativo do valor das amostras do PCR, o sinal do relógio do receptor é ajustado.

Os métodos descritos nesta seção são bastante eficientes para a reconstrução do relógio do emissor, entretanto, dependem de implementações complexas baseadas em hardware. Por essa razão, eles não são utilizados como base para o método utilizado no framework proposto nesta dissertação, que é implementado inteiramente por software.

\subsubsection{Algoritmo de Correção da Periodicidade das Amostras do Relógio do Emissor}

Este algoritmo, proposto por Yu (YU; NAHRSTEDT, 2002), denominado "Padding Algorithm", é baseado em procedimentos que podem ser implementados totalmente em software, ao contrário de outros mecanismos mais intuitivos, como a geração de novas amostras do PCR, no caso de manipulações nas mídias ou no fluxo de transporte.

A solução de Yu utiliza pacotes TS nulos para garantir o sincronismo, sem a necessidade de modificar os valores do PCR e mantendo preservada a distância entre pacotes que contenham amostras do PCR. O algoritmo insere bits de enchimento aos pacotes TS, ao final dos dados úteis, ou inclui pacotes TS nulos, na proporção necessária para compensar reduções no número de bytes de mídias após 
Mecanismos de sincronização do MPEG2 System

manipulações, tais como: recodificação de vídeos, remultiplexação de programas e operações de filtragem (filtros passa-baixas). Por exemplo, no caso da recodificação de um vídeo para diminuir a taxa de bits do vídeo com o intuito de adaptar o fluxo de vídeo a restrições de largura de banda na rede de distribuição, poderiam ser inseridos bytes em número equivalente aos eliminados por essa operação.

No entanto, pode-se notar que esse método só é possível quando operações sobre o fluxo de transporte reduzem o número de bytes das mídias, pois a posição dos pacotes que contém amostras do PCR deve ser mantida inalterada para que a taxa de bits permaneça constante, assim como os valores das amostras do PCR. Outro ponto importante é que, para manter o sincronismo, é sacrificado o ganho com otimizações tais como recodificações e filtragens passa-baixas.

Esse algoritmo pode ser utilizado para compensar a chegada prematura de pacotes que contêm amostras do PCR. Com uma constante monitoração da distância entre amostras do PCR consecutivas, pode ser compensada a variação de distância por meio da inserção de pacotes TS nulos na proporção de bytes faltantes. Esse mecanismo é simples, e assim também é sua implementação.

\subsubsection{Algoritmo de Reposicionamento de pacotes com Escalonamento da Taxa de bits}

$\mathrm{O}$ algoritmo descrito nesta seção e proposto em Yu (YU; NAHRSTEDT, 2002), denominado "Time-invariant Bit Rate Scaling Algorithm",tem como objetivo modificar a taxa de bits, determinada pela distância entre amostras do PCR, para um novo valor constante. Assim, pode-se ressincronizar o fluxo de transporte, sem que seja necessária a modificação dos valores das amostras do PCR. Ou seja, uma transformação da taxa de bits é efetuada, refletindo a mudança no número de pacotes entre amostras consecutivas do PCR ou a distância entre eles, determinando assim uma nova taxa constante que preservará, assim, o sincronismo.

O algoritmo calcula a distância (em número de pacotes/bytes ou em unidades de tempo) de cada pacote TS, exceto dos que carregam vídeo, em relação ao último PCR, multiplicando essa distância por um fator $s$, sendo o resultado utilizado para determinar a distância entre esse pacote e a amostra do PCR no novo Fluxo de Transporte. A figura 4.6 ilustra o método, utilizando uma redução da taxa de bits. 
Mecanismos de sincronização do MPEG2 System

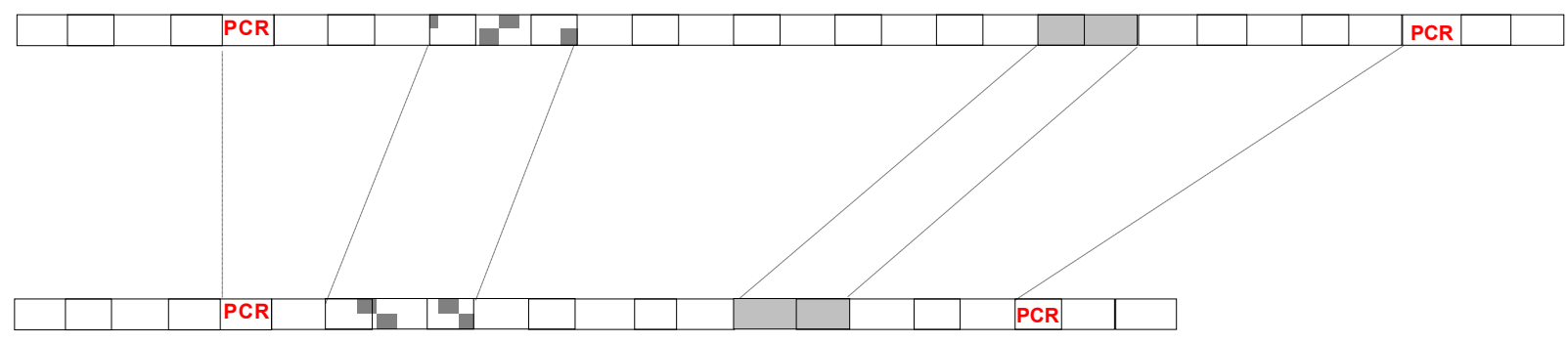

Pacotes TS dados $\square$ Pacotes TS

Pacotes TS

Figura 4.6 - Exemplo da transformação da taxa de bits.

A transformação da taxa de bits pode ser utilizada nos casos em que exista um pacote contendo amostras do PCR atrasadas, ou seja, estão presentes mais pacotes TS, entre a amostra atual do PCR e a última , ou a distância entre amostras do PCR é maior que a esperada. Um escalonamento dos pacotes entre as duas amostras do PCR deve ser feito e, assim, uma nova taxa de bits determinada para o fluxo de transporte. As amostras do PCR subseqüentes indicam se é necessário escalonar a taxa novamente ou não, sendo a nova taxa mantida até que seja necessária uma nova modificação.

Alguns aspectos, no entanto, não são bem esclarecidos em Yu (YU; NAHRSTEDT, 2002). Por exemplo, como é efetuada a redução da taxa de bits do vídeo sem que sejam perdidas informações relevantes de seus quadros? Quaisquer pacotes contendo vídeo podem ser descartados ou algum esquema especial de decisão deve ser implementado de forma a definir quais os pacotes a descartar? Para responder tais questionamentos propõe-se, na seção 5.3, um framework para testes e avaliação do sincronismo, por meio do qual alguns mecanismos de transformação da taxa de bits são testados. 


\section{PROPOSTA DO FRAMEWORK PARA TESTES E AVALIAÇÃO DO SINCRONISMO}

Neste capítulo, é detalhada a proposta desta dissertação para o framework para testes e avaliação de sincronismo, que utiliza os mecanismos de ressincronização de mídias em receptores e remultiplexadores apresentados no capítulo 4.

Dois dos algoritmos detalhados no capítulo 4 são utilizados na implementação do framework proposto, os algoritmos propostos nas seções 4.3.2 e 4.3.3. O primeiro é utilizado para corrigir a variação de atraso entre amostras consecutivas do relógio (PCR), no caso dessas amostras chegarem adiantadas. O segundo é utilizado com o intuito de reposicionar as amostras do PCR no fluxo de transporte, de forma a tornar a variação de atraso entre duas amostras consecutivas do PCR a menor possível. O segundo algoritmo tem utilização quando há um atraso na chegada das amostras do PCR.

A implementação de um sistema baseado nesses dois algoritmos permite resolver problemas tanto de atraso como de adiantamento de pacotes no fluxo de transporte, corrigindo tais desvios. Pretende-se, com isso, garantir maior qualidade na apresentação das mídias. Uma das contribuições desta dissertação é justamente a proposta de utilização conjunta desses dois algoritmos, para atender a todas as situações possíveis da chegada de amostras do PCR e, assim, minimizar os efeitos da variação de atraso da rede de distribuição.

Na próxima seção, é apresentada a proposta do método de ressincronização de mídias utilizado no framework, que consiste na adaptação desses dois algoritmos, de forma a trabalharem em conjunto. Em seguida, na seção 5.2, é detalhado como esses algoritmos se inserem no framework para testes e avaliação do sincronismo.

\subsection{Proposta de Ressincronização de Mídias}

O objetivo desta seção é propor um método de ressincronização de mídias a fim de solucionar alguns dos problemas inerentes à distribuição de Fluxos de Transporte (MPEG2 Transport Stream) por redes de pacotes até as estações 
Proposta do Framework para testes e avaliação do sincronismo

transmissoras de TV digital, ou seja, utilização de redes primárias de distribuição baseadas em redes de pacotes. Como detalhado nos capítulos 3 e 4, aplicações de TV digital, com recepção móvel, que utilizam essa modalidade de redes, devem observar aspectos de sincronismo, para garantir boa qualidade na recepção e apresentação das mídias.

A sincronização das mídias depende, em grande medida, dos atrasos e variações de atraso que apresentam os pacotes do Fluxo de Transporte que contêm as amostras do relógio do emissor (PCR), pois a distância entre amostras consecutivas (delta_t e delta_tb, por exemplo) pode variar devido a flutuações nos atrasos. Essa distância determina a taxa de decodificação dos bytes dos fluxos elementares (vídeo e áudio) e variações excessivas podem provocar a perda de sincronismo nos mecanismos de reconstrução do relógio nos receptores, por exemplo em "phasedlocked loops" (PLLs).

$\mathrm{Na}$ figura 5.1, a influência das variações na distância entre amostras consecutivas da referência de tempo, para a reconstrução do relógio no receptor, é mostrada, podendo ser observado o reflexo nas transições do relógio reconstruído (em inglês, clock ticks). Nota-se que uma mudança na distância entre amostras do PCR determina uma taxa menor, ou maior, de decodificação, pois as referências de tempo do relógio mudam seu espaçamento. A situação ideal, considerada no modelo de sincronismo do MPEG2 System, descrito no capítulo 4, é obtida quando a distância temporal entre os bytes i' e i”, das amostras do PCR, é igual à diferença dos instantes registrados nessas amostras do PCR. 


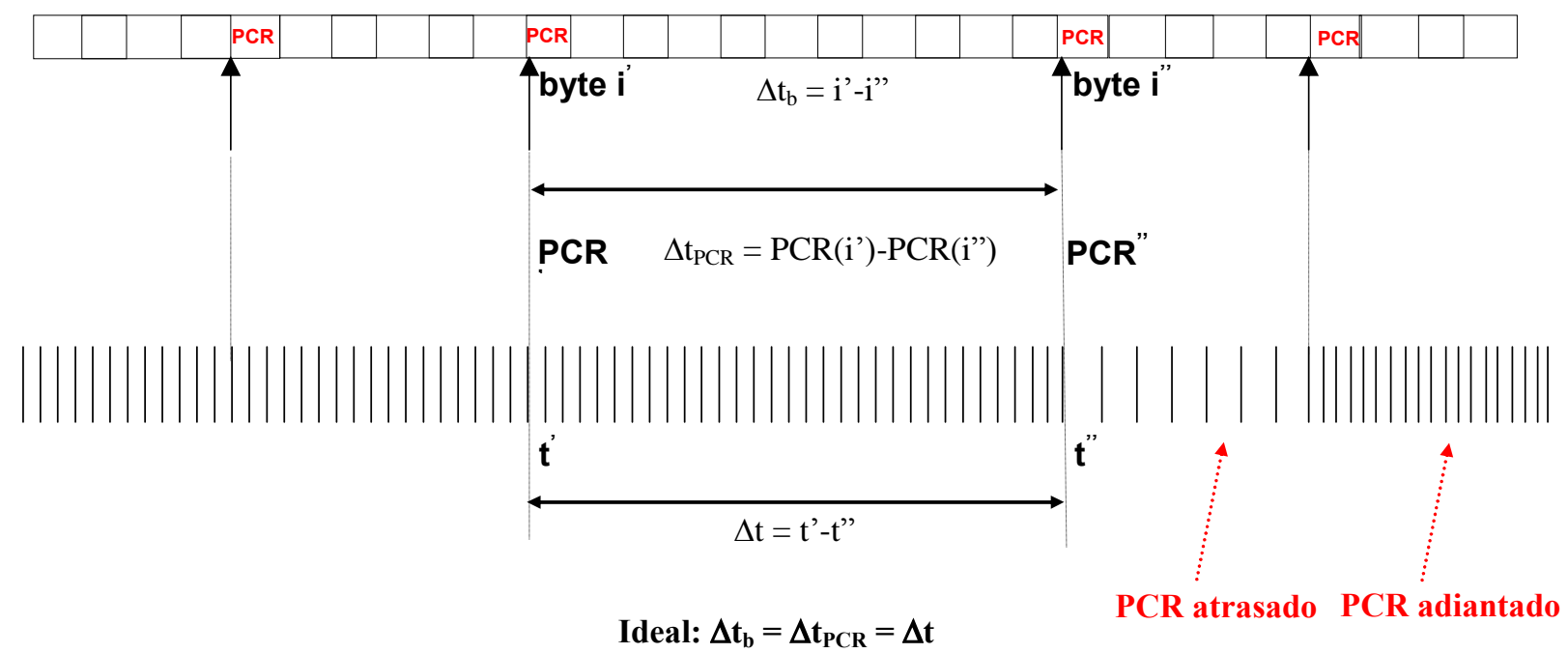

Figura 5.1 - Influência das variações na distância entre amostras do PCR

Para corrigir as distorções, ilustradas pela figura 5.1, podem-se efetuar os seguintes procedimentos:

- Caso um pacote que contém uma amostra do PCR esteja adiantado, é possível inserir pacotes TS nulos ou bytes de enchimento, na proporção dos pacotes faltantes para manter a distância entre amostras do PCR original;

- Caso um pacote que contém uma amostra do PCR esteja atrasado, pode-se reposicionar os pacotes TS de forma que se atinja novamente a distância entre amostras do PCR original.

Os mecanismos apontados acima são implementados, em parte, pelos algoritmos propostos por $\mathrm{Yu}$ (YU; NAHRSTEDT, 2002), que foram descritos sucintamente na seção 4.3. Entretanto, a proposta desta dissertação é contemplar ambos os aspectos mencionados acima. Para isso, os dois algoritmos serão implementados dentro de um framework de testes e avaliação de sincronismo, para que sejam testados e seu desempenho avaliado. Na próxima seção, e nos próximos capítulos, são descritos os mecanismos utilizados para implementar e testar o framework, assim como são apresentados os resultados obtidos. 
Proposta do Framework para testes e avaliação do sincronismo

\subsection{Framework para Testes e Avaliação do Sincronismo}

O framework proposto por esta dissertação tem como objetivo estudar a influência das perturbações causadas por redes de pacotes e por remultiplexações no sincronismo de programas MPEG2 inseridos no fluxo de transporte. O framework tem como base a introdução de atrasos e variações de atrasos aos pacotes do fluxo de transporte (MPEG2 Transport Stream) para mostrar a influência dessas perturbações na apresentação das mídias aos usuários. Adicionalmente, são implementados algoritmos de ressincronização de mídias, que podem corrigir as distorções no sincronismo, causadas pelas perturbações inseridas previamente.

Esse framework possibilita o estudo dos parâmetros relevantes para o sincronismo dos programas MPEG2 (valor de amostras do PCR e PTS/DTS, distância entre amostras do PCR, etc) para a especificação e a implementação de algoritmos de ressincronização mais eficientes, que possam melhorar a apresentação de vídeo e áudio aos usuários finais, agindo diretamente nesses parâmetros.

O framework possibilita, também, determinar parâmetros que indiquem quando vale a pena efetuar a ressincronização de mídias. Além disso, é possível mapear a qualidade da imagem e áudio antes e depois do ressincronismo de forma a verificar se a melhora no desempenho na apresentação das mídias é conseguida com um tempo de processamento razoável. Ou seja, podem ser feitas análises de "custo/benefício" dos algoritmos implementados e, ainda, determinar limiares de variação de atraso, para os quais, apesar de não haver perda excessiva de qualidade, vale a pena ou não aplicar a ressincronização. Baseado nisso, é possível também ajustar os parâmetros dos algoritmos utilizados.

Para a construção do framework, propõe-se a estrutura de uma rede primária de teste (figura 5.2), para a transmissão de pacotes de um fluxo de transporte. As características dessa rede, ou seja, atrasos, variações de atrasos, banda disponível, etc, são controladas. Adicionalmente, a influência dessa rede na apresentação das mídias será avaliada por meio de medições da qualidade objetiva do vídeo apresentado ao usuário (PINSON; WOLF, 2004; SINGH, 2005). 


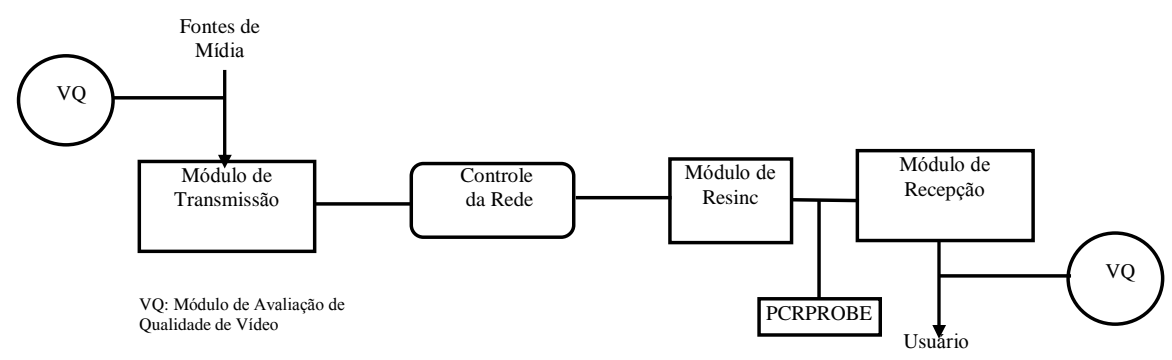

Figura 5.2 - Rede primária de testes.

Cada um dos módulos do framework, proposto e apresentado na figura 5.2, tem uma função na simulação de redes de pacotes para a distribuição de conteúdo. $\mathrm{O}$ framework é composto pelos seguintes módulos:

- Módulo de Transmissão: Esse módulo tem o objetivo de efetivamente gerar os pacotes TS, a partir de um arquivo residente no computador em que está sendo executado. Em outras palavras, esse módulo transmite pacotes de um fluxo de transporte a partir de um arquivo formatado previamente com as características desejadas. O Fluxo de Transporte definido possui características especiais, pois apresenta, tanto cenas de movimento intenso, quanto cenas estáticas com um apresentador (Rugby na emissora TelePiu da Itália). Com essas duas modalidades de exibição varia-se o nível de atividade do vídeo e, em conseqüência, é possível comparar o efeito das mudanças nos parâmetros da rede para as duas opções. Qualquer software que implemente a transmissão de pacotes TS (encapsulados em UDP e IP), utilizando uma interface de rede IP, pode ser utilizado (servidores de streaming);

- Módulo de Controle da Rede: Esse módulo tem a função de simular as condições reais de uma rede de pacotes utilizada para a distribuição de conteúdo em banda base (pacotes TS não modulados). A maioria dos problemas, encontrados nesse tipo de rede, podem ser reproduzidos por esse módulo: atraso de trânsito, erros de encaminhamento e roteamento, congestionamento, etc. Cada um desses problemas tem efeitos particulares, por exemplo: o atraso de trânsito insere um atraso para todos os pacotes. Decisões de encaminhamento diferentes para cada pacote, por exemplo, devido ao congestionamento nos buffers de roteadores, podem causar variação de atraso. Congestionamentos na rede podem 
Proposta do Framework para testes e avaliação do sincronismo

levar a perda de pacotes. Além disso, erros de roteamento podem ocasionar duplicação de pacotes. Esse módulo atua nesses parâmetros (atraso, variação de atraso, perda de pacotes, duplicação de pacotes), os quais são controlados minuciosamente para que se possa estabelecer uma relação a posteriori entre eles e a qualidade do vídeo recebido no cliente de streaming;

- Módulo de Ressincronismo: Esse módulo tem como principal objetivo atuar no fluxo de transporte para minimizar os efeitos de variações de atraso em pacotes TS. Para isso, são utilizados programas que modificam características dos pacotes TS e de seu conteúdo, de forma a ressincronizar o fluxo de transporte, quando necessário. Essa ressincronização é feita a partir da implementação dos algoritmos descritos na seção 5.1. Os requisitos principais desse módulo são a simplicidade e a rapidez no processamento, pois a solução utilizada não pode prejudicar a recepção dos pacotes TS pelo cliente de streaming. Para a prova de conceito foi escolhida uma solução em software devido a sua simplicidade quando comparada a soluções em hardware, considerando que a eficiência no processamento deve ser um dos requisitos no seu desenvolvimento;

- Módulo de Recepção: Constitui-se como um cliente de streaming, que neste caso simula o set-top box e o aparelho de TV Digital. Tem o papel de receber os pacotes TS enviados pelo servidor de streaming e redirecioná-los tanto para a tela do computador, onde está sendo executado, como para um arquivo. Para implementar essas funções, o software cliente terá que interpretar as tabelas PSI (Program Specific Information) (ISO 13818-1, 1994), por exemplo, PAT (Program Allocation Table) e PMT (Program Map Table) do Fluxo de Transporte; demultiplexar as mídias de cada programa existente; decodificá-las e exibí-las na tela do computador. Ao mesmo tempo, o cliente deverá gravar os pacotes TS recebidos, em um arquivo residente no computador, para análises futuras. Essas duas tarefas são essenciais para a avaliação da transmissão, pois indicam o comportamento da exibição, no momento em que ela está ocorrendo (exibição na tela), e possibilitam uma análise posterior pelo módulo de avaliação de qualidade de vídeo (arquivo);

- Módulo de Avaliação da Qualidade de Vídeo (VQ): Esse módulo tem o papel de analisar a qualidade dos vídeos recebidos pelo cliente de streaming de forma 
Proposta do Framework para testes e avaliação do sincronismo

objetiva, ou seja, efetuando algumas medições da qualidade. Podem ser utilizadas métricas como o PSNR ${ }^{33}$ (HENG, 2004; SINGH, 2005), MSE $^{34}$ (REIBMAN ET AL, 2004; AEHURI ET AL, 2004; HENG, 2004) ou métricas mais sofisticadas como o VQM ${ }^{35}$ (Video Quality Metric) (PINSON; WOLF, 2004), que faz análises de referência completa ou de referência reduzida para os vídeos original e recebido. Esse módulo deve extrair os vídeos do arquivo gravado no computador de destino e calcular alguma métrica que indique a qualidade do vídeo recebido. Com essa métrica, podemos comparar o desempenho da exibição em diversas condições de transmissão. Sendo assim, torna-se muito importante relacionar as condições da rede com a métrica calculada. $\mathrm{O}$ resultado obtido por meio desse módulo pode ser utilizado para avaliar os algoritmos implementados no módulo de ressincronismo, assim como para estudar a influência dos parâmetros de rede na qualidade da exibição.

- Módulo de Monitoração das Características das Amostras do PCR (PCRPROBE): Este módulo tem o objetivo de extrair as principais características das amostras do PCR do Fluxo de Transporte transmitido. Essas características são registradas em um arquivo de saída para posterior análise. As métricas obtidas são, dentre outras: distância em bytes entre amostras consecutivas do PCR, valor das amostras do PCR em microssegundos, diferença entre a amostra atual do PCR e a imediatamente anterior, diferença do instante de chegada da amostra do PCR e o instante de chegada da amostra imediatamente anterior, e a variação de atraso das amostras do PCR.

A rede primária de testes utiliza hosts conectados através de redes locais, podendo ser utilizado o VideoLAN ${ }^{36}$ para atuar como servidor e cliente de streaming na transmissão. Para o módulo de controle da rede pode ser utilizado o NISTNet ${ }^{37}$, que é um pacote de software de domínio público, usado para simular diversas condições de uma rede de dados. Ele simula um roteador e controla a perda de pacotes, atraso, variação de atraso e banda máxima disponível da rede. O módulo de

\footnotetext{
${ }^{33}$ PSNR, do inglês, Peak Signal to Noise Ratio.

${ }^{34}$ MSE, do inglês, Mean Square Error.

${ }^{35}$ VQM, do inglês, Vídeo Quality Metric.

${ }^{36}$ VIDEOLAN. Disponível em: <http://www.videolan.org>. Acesso em: 30 jan. 2006.

${ }^{37}$ NISTNET. Disponível em: <http://snad.ncsl.nist.gov/nistnet/>. Acesso em: 30 jan. 2006.
} 
Proposta do Framework para testes e avaliação do sincronismo

ressincronização utiliza os algoritmos descritos no capítulo 4 e atua nos efeitos da variação de atraso em pacotes TS. Ou seja, quando o pacote TS chega ao receptor atrasado, ou adiantado, em relação ao atraso permitido pelo modelo de sincronismo do MPEG2 System. Para o módulo de avaliação da qualidade do vídeo pode ser usado o VQM, Vídeo Quality Measurement Tool ${ }^{38}$, que é um pacote de software disponibilizado gratuitamente pelo NTIA (National Telecomunication Industry Association, órgão do governo americano) a institutos de pesquisa e universidades. $\mathrm{O}$ VQM efetua medidas de qualidade objetiva de vídeo através de padrões obtidos do vídeo original e do vídeo recebido no terminal final. Os algoritmos utilizados pelo VQM são descritos pelos autores em (PINSON; WOLF, 2004). Alternativamente, podem ser implementados algoritmos para medir outras métricas, como o PSNR ou a MSE, dos vídeos recebidos. Finalmente, no PCRPROBE, podem ser implementados algoritmos para extrair as características desejadas do fluxo de transporte.

Dentre os módulos desse framework, apenas dois permitem uma atuação direta na rede primária de teste: o módulo de controle da rede e o módulo de ressincronização. O primeiro pode ser utilizado para simular as condições reais de uma rede de pacotes e o segundo pode minimizar os efeitos da variação de atraso no sincronismo, como descrito acima.

Com o framework proposto, podem ser feitas simulações com o intuito de definir limites toleráveis para as características da rede primária (principalmente variação de atraso e perda de pacotes), de forma a manter a qualidade objetiva do vídeo apresentado ao usuário. Podem ser avaliados também o desempenho de algoritmos de ressincronização na presença de variação de atraso na rede. Além disso, algumas questões importantes podem ser esclarecidas por meio de testes utilizando o framework proposto:

- Qual a influência de parâmetros, como a variação de atraso e a perda de pacotes, na qualidade do vídeo? Ou seja, como métricas de qualidade de vídeo, como PSNR ou MSE, variam à medida que variam esses parâmetros da rede?

- A duplicação de pacotes produz efeitos negativos para a qualidade do vídeo recebido?

\footnotetext{
${ }^{38}$ VQM. Disponível em: <http://www.its.bldrdoc.gov/n3/video/vqmsoftware.htm>. Acesso em: 30 jan.
} 
Proposta do Framework para testes e avaliação do sincronismo

- Qual o valor limite para a variação de atraso de forma que os algoritmos de ressincronismo consigam evitar a perda de sincronismo na exibição do vídeo?

- Qual parâmetro da rede determina a maior distorção do vídeo recebido? Ou seja, qual das características da rede que mais influencia na exibição do vídeo ao usuário?

As questões acima são relevantes para indicar quais são os limites razoáveis de atraso, variação de atraso e perda de pacotes que possibilitam uma exibição das mídias com qualidade. Além disso, as respostas a essas questões tornam possível avaliar em que medida os algoritmos de ressincronização, descritos na seção 4, podem ajudar a manter o sincronismo das mídias, contribuindo indiretamente para uma melhor qualidade de exibição.

O framework proposto pode avaliar os efeitos do sincronismo na exibição das mídias, independentemente da compressão utilizada (MPEG1, MPEG2, MPEG4, etc), pois são analisados os fluxos de transporte que carregam os quadros dos vídeos comprimidos e não os vídeos em si. Apesar disso, na análise de qualidade objetiva dos vídeos deve ser observada a compressão utilizada, pois cada métrica leva em consideração as características do vídeo.

Outro aspecto, bastante relevante, é a integração entre os módulos do framework, que é fundamental para efetivamente simular uma rede de distribuição de conteúdo baseada em transmissão de pacotes. Deve-se garantir, portanto, que os módulos estejam conectados através de uma rede de pacotes. Nota-se, que vários aspectos devem ser observados para viabilizar os estudos desejados através desse framework.

Após a breve descrição acima, torna-se necessário um detalhamento das partes integrantes do framework proposto. Sendo assim, no próximo capítulo, são descritos mais extensamente cada um dos módulos do framework, suas especificações e premissas de projeto. 


\section{ESPECIFICAÇÃO DOS MÓDULOS DO FRAMEWORK PARA TESTES E AVALIAÇÃO DO SINCRONISMO}

Neste capítulo, são descritos os aspectos fundamentais da implementação de cada um dos módulos, as decisões de projeto envolvidas e as definições de parâmetros essenciais para cada um dos módulos. A especificação de cada módulo envolve a fundamentação da escolha ou do desenvolvimento de um determinado software para integrar o framework. Quando a decisão acarreta desenvolvimento do módulo, são descritos os principais conceitos envolvidos e como ocorreu esse desenvolvimento.

\subsection{Módulo de Transmissão}

Como descrito na seção anterior, o módulo de transmissão, no framework proposto, funciona como um servidor de streaming e tem o objetivo principal de simular a transmissão de Fluxos de Transporte por uma rede de distribuição baseada no protocolo IP. Em um contexto mais amplo, este módulo representa a união de todo e qualquer equipamento indispensável para a transmissão dos pacotes TS até a antena transmissora da rede primária, ou seja, os moduladores e transmissores propriamente ditos.

Em uma implementação real, os seguintes equipamentos podem constituir a parte da rede de distribuição associada ao módulo de transmissão: equipamentos de armazenagem de vídeos e áudio, codificadores e transcodificadores de vídeo e áudio, multiplexadores e servidores de streaming em redes IP, e outros. Portanto, esse módulo simula a codificação, multiplexação e transmissão de sinais de vídeo e áudio através de uma rede de distribuição baseada no protocolo IP.

No ambiente utilizado para testes de sincronismo, que deveria ser controlado para que pudessem ser registrados os diversos parâmetros de transmissão, foi utilizado o VLMS (VideoLAN Miminum Server), uma versão simplificada de um servidor de streaming de código aberto bastante conhecido - VideoLAN ${ }^{39}$. Esse

\footnotetext{
${ }^{39}$ VIDEOLAN. Disponível em: <http://www.videolan.org>. Acesso em: 30 jan. 2006.
} 
Especificação dos módulos do framework para testes e avaliação do sincronismo

software foi escolhido porque atende a requisitos mínimos de sincronismo e não modifica as características do fluxo de transporte. $\mathrm{Na}$ escolha do VLMS foram muito importantes duas de suas características: a simplicidade de sua implementação e o controle total das tarefas do servidor de streaming, já que o código fonte do VLMS era conhecido.

O VLMS é um programa em linha de comando que efetua basicamente três atividades:

- Leitura, a partir do disco rígido, de um arquivo pré-formatado contendo o fluxo de transporte, ou seja, pacotes TS contendo vídeos, áudio, e dados, em especial, as amostras do relógio do emissor (PCRs);

- Sincronização do fluxo de transporte de saída por meio das amostras contidas no arquivo gravado em disco, ou seja, o programa lê as amostras do PCR e determina qual o instante de tempo mais apropriado para a transmissão de um determinado pacote TS;

- Transmissão dos pacotes TS através de um socket de saída para a rede IP. O VLMS encapsula sete pacotes TS (188 bytes) em pacotes UDP, ou seja, um payload de 1316 bytes.

A interação ocorre por meio da linha de comando, a qual é utilizada para configurar o VLMS especificando os parâmetros de entrada do programa. Na figura 6.1 são apresentadas as informações de entrada para o VLMS. Verifica-se que é especificado diretamente o endereço IP e a porta do destino da transmissão, o PID (Packet Identifier) do vídeo contido nos pacotes TS e o nome do arquivo contendo o fluxo de transporte.

No entanto, o VLMS não implementa funcionalidades como: compensação de parâmetros de QoS (atrasos, variação de atraso, perdas e duplicações de pacotes), ou dispõe de recursos para tornar a transmissão mais robusta, por exemplo, FEC (Forward Error Correction), retransmissões (WU ET AL, 2000), etc. 
Especificação dos módulos do framework para testes e avaliação do sincronismo

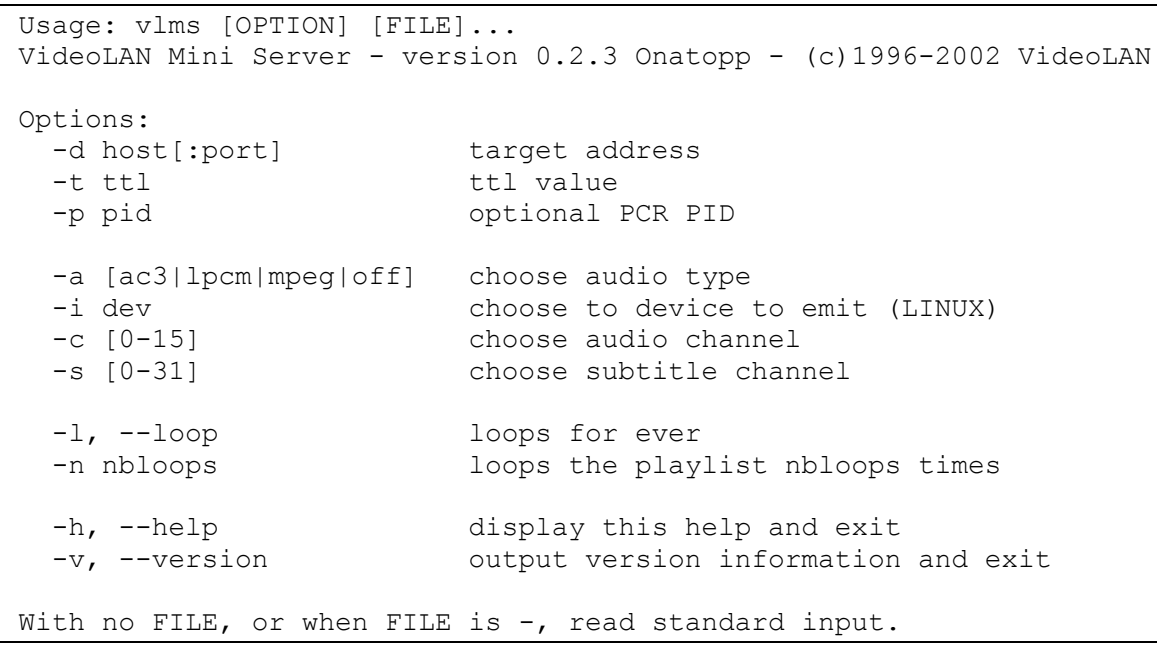

Figura 6.1 - Interface de linha de comando do VLMS.

\subsection{Módulo de Controle da Rede}

O Módulo de Controle da Rede é um dos módulos fundamentais do framework proposto. Ele possibilita a atuação direta sobre os parâmetros de QoS da rede de distribuição e assim simula uma rede de pacotes IP que pode ser constituída por diversos roteadores.

O Software que possibilita a implementação desse módulo é o NISTNet ${ }^{40}$. Esse software foi desenvolvido para o sistema operacional linux (kernels 2.4 e 2.6), e utiliza os recursos de roteamento do linux de forma a simular um roteador num PC. Ou seja, o NISTNet transforma uma máquina convencional em roteador e assim pode-se configurar uma rede de pacotes por meio da interconexão de diversas máquinas executando o NISTNet.

O NISTNet possui uma interface gráfica bastante simples, mostrada na figura 6.2, por meio da qual podem ser configurados atrasos, variação de atraso, perda de pacotes, duplicação de pacotes e banda máxima disponível. Além disso, o NISTNet monitora os parâmetros da rede em tempo real, ou seja, pode ser monitorada a transmissão e alguns parâmetros da rede (banda média utilizada, tamanho médio dos pacotes, bytes transmitidos, etc). Outra funcionalidade interessante do NISTNet é a

${ }^{40}$ NISTNET. Disponível em: <http://snad.ncsl.nist.gov/nistnet/>. Acesso em: 30 jan. 2006. 
Especificação dos módulos do framework para testes e avaliação do sincronismo

possibilidade de configurar diversas regras para uma única máquina, ou seja, os parâmetros de QoS podem ser modificados para cada par de endereços IP de origem e destino numa determinada transmissão.

O NISTNet pode, com bastante precisão, simular um roteador, com suas diversas regras e condições específicas, determinando parâmetros diferentes para cada subrede. Como o linux implementa funções de roteamento entre interfaces de uma determinada máquina, o PC executando o NISTNet pode atuar como um roteador de fato.

Diversas condições de uma rede de pacotes podem ser simuladas por meio do NISTNet, dentre elas:

- Atraso: O NISTNet pode adicionar atrasos fixos e variáveis, além de possibilitar a configuração de uma função distribuição de probabilidade de atraso ou um atraso médio e sua variância;

- Reordenamento de pacotes: Quando são especificadas variações de atraso muito elevadas é possível simular essa condição;

- Perda de Pacotes: Pode ser explicitada uma probabilidade uniforme de perda de pacotes ou dependente de congestionamento, de forma a simular condições de congestionamento em roteadores;

- Duplicação de Pacotes: Pode ser explicitada uma probabilidade uniforme de duplicação de pacotes;

- Limitação de Banda: Pode ser explicitado um valor limite para a banda disponível em determinada transmissão, sendo geralmente utilizada em conjunto com a configuração de perda de pacotes dependente do congestionamento. 
Especificação dos módulos do framework para testes e avaliação do sincronismo

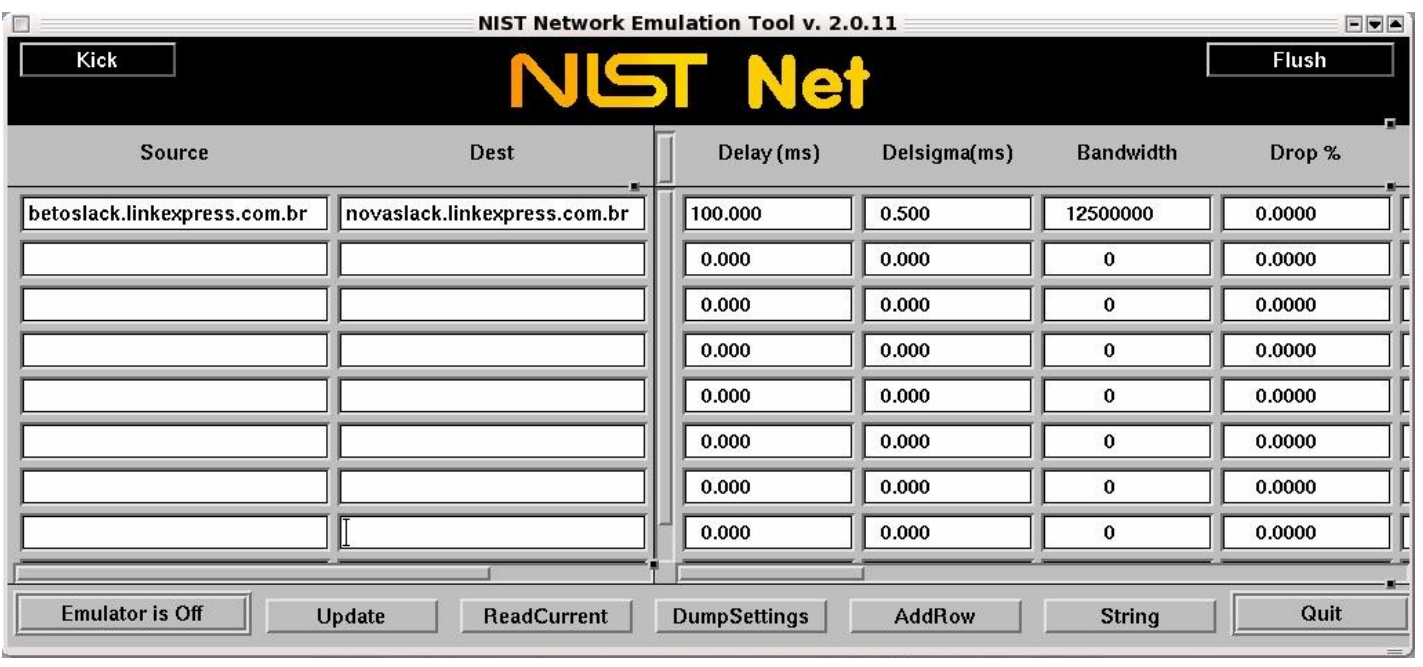

Figura 6.2 - Interface gráfica do NISTNet 2.0.12b executado na distribuição

Slackware Linux 10.1.

\subsection{Módulo de Ressincronismo}

Este módulo é fundamental para o framework proposto, pois, por meio de sua atuação sobre o Fluxo de Transporte, é possível verificar a eficácia da ressincronização do Fluxo de Transporte. $\mathrm{O}$ framework proposto tem como objetivo simular as condições de uma rede de distribuição real. Em uma implementação real, esse módulo seria constituído por equipamentos específicos que implementariam em hardware tarefas como a ressincronização do Fluxo de Transporte, a geração de novas amostras do relógio (PCR), e mecanismos adicionais, como requantização e descarte de pacotes.

A eficiência de uma implementação em hardware, comparada com uma solução em software, é diferente, entretanto, como prova de conceito do framework proposto, uma implementação em software foi um dos requisitos do projeto. Sendo assim, foram implementados alguns algoritmos de ressincronização, que demandaram algumas decisões de projeto em sua especificação, para tornar o módulo de ressincronismo rápido o suficiente para que sua atuação não comprometesse o desempenho global do sistema e, conseqüentemente, se mantivesse inalterada a qualidade da exibição do vídeo para uma determinada condição da rede. 
Especificação dos módulos do framework para testes e avaliação do sincronismo

Os métodos de ressincronização implementados pelo framework utilizam os mecanismos descritos na seção 5.2 para atuar em ambos os efeitos da variação de atraso em pacotes TS trafegando por redes de pacotes, ou seja, pacotes TS chegando atrasados, ou adiantados, ao receptor, em relação aos atrasos permitidos pelo modelo de sincronismo do MPEG2 System, descrito no capítulo 4.

Na figura 6.3, é apresentado um diagrama de blocos dos métodos propostos no framework, para a ressincronização de programas MPEG2 em Fluxos de Transporte. Portanto, a figura ilustra os mecanismos implementados, no framework, para corrigir as perturbações inseridas pelo módulo de controle da rede. Pode-se notar que o processo ocorre em três etapas: análise do Fluxo de transporte, cálculo da variação de atraso das amostras do PCR e mecanismos para corrigir distorções da variação de atraso das amostras do PCR (inserção de pacotes TS nulos ou reposicionamento de pacotes contendo amostras do PCR).

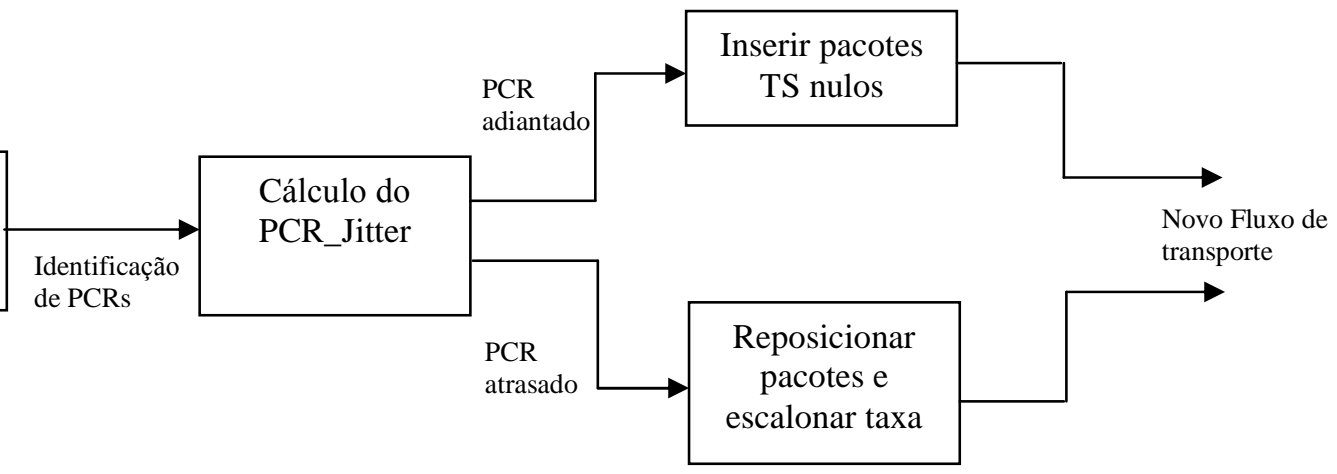

Figura 6.3 - Diagrama de blocos do sistema de ressincronização.

A primeira decisão de projeto foi a de como implementar os blocos do diagrama da figura 6.3. No caso da análise do Fluxo de Transporte e do cálculo da variação de atraso das amostras do PCR, o módulo implementa uma análise direta sobre os bytes dos pacotes TS, de forma a identificar as informações dos cabeçalhos dos pacotes TS, do campo de adaptação e do payload. A implementação dos dois blocos principais (inserção de pacotes nulos e reposicionamento de pacotes) será descrita nas subseções a seguir. 
Especificação dos módulos do framework para testes e avaliação do sincronismo

\subsubsection{Módulo de inserção de pacotes nulos}

Apesar de aparentemente simples, a inserção de pacotes nulos depende da correta análise do Fluxo de Transporte e avaliação da variação de atraso das amostras consecutivas do PCR. Por isso, nesta seção, a implementação de três dos blocos do diagrama da figura 6.3 é descrita em detalhe: Implementação da Análise do Fluxo de Transporte, do Cálculo da variação de atraso das amostras do PCR e da Inserção de pacotes nulos.

A Análise do Fluxo de Transporte baseia-se fundamentalmente no correto recebimento dos pacotes TS e na correta interpretação do cabeçalho de cada pacote. Para efetuar as tarefas de análise do fluxo de transporte, foram implementadas, dentro do módulo de ressincronismo, algumas funções que recebem os pacotes TS, analisam seus cabeçalhos, identificam a existência do campo de adaptação, contendo uma amostra do PCR, transformam os bytes das amostras do PCR em valores de tempo, em microssegundos, de acordo com o relógio do transmissor, e retransmitem os pacotes TS. Em todo o processo, levou-se em consideração que o módulo de ressincronismo não poderia interferir na transmissão fim-a-fim entre o módulo de transmissão e recepção. Dessa forma, as intervenções visam apenas obter informações essenciais para a implementação dos algoritmos de ressincronização.

As funções que recebem e retransmitem os pacotes TS foram implementadas por meio das API de sockets do linux. Para receber os pacotes TS, um socket é aberto para leitura de uma porta UDP, por onde são recebidos os pacotes TS enviados pelo módulo de transmissão. Assim que um determinado pacote UDP contendo pacotes TS é recebido, o campo de dados desse pacote UDP é imediatamente gravado num buffer de análise para posterior investigação. No caso da transmissão ou retransmissão de pacotes TS, o conteúdo do buffer de análise é encapsulado num pacote UDP e transmitido por meio de um socket de saída. O pseudo-código dessas duas funções é apresentado na figura 6.4. 


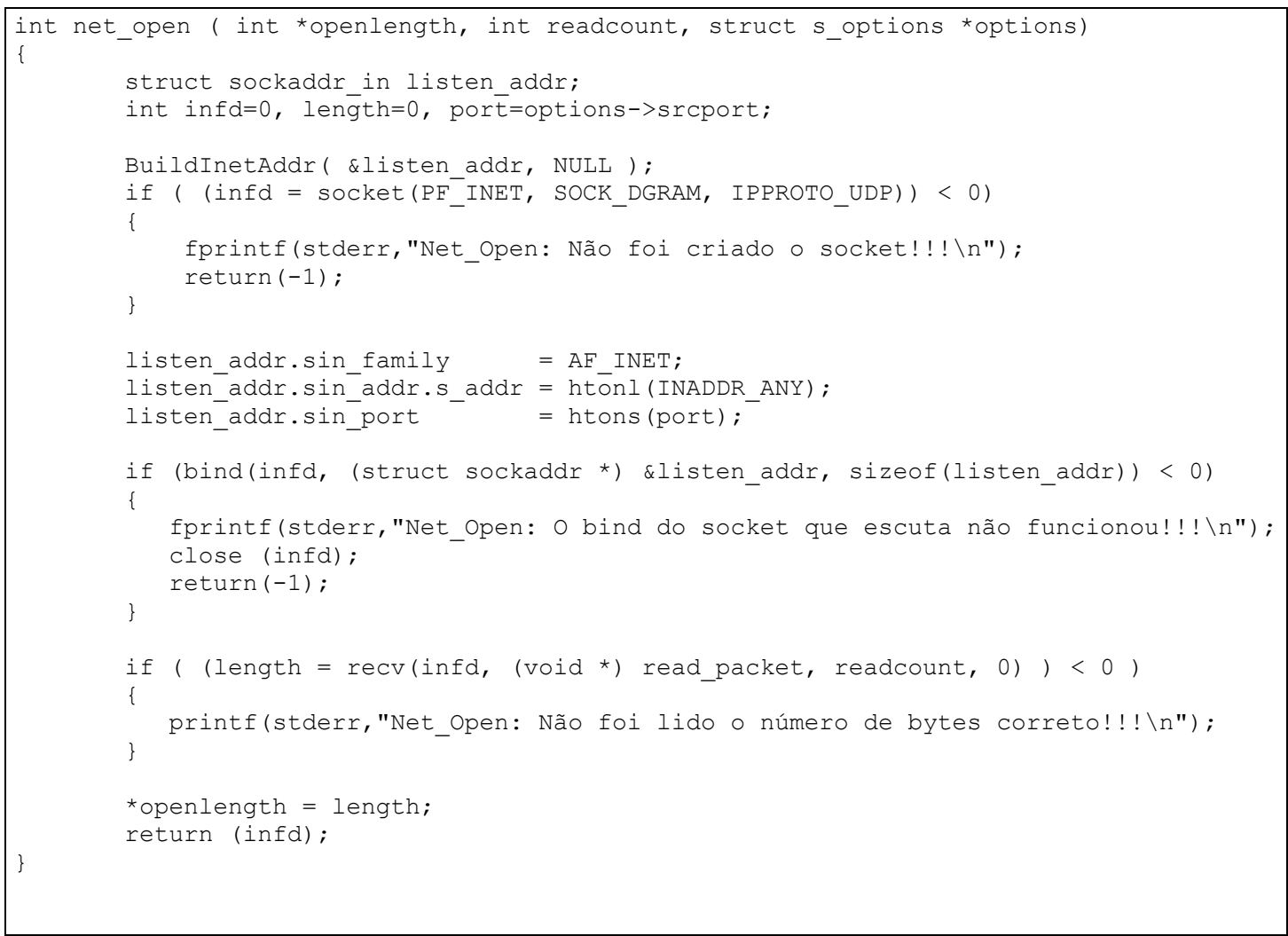

(a)

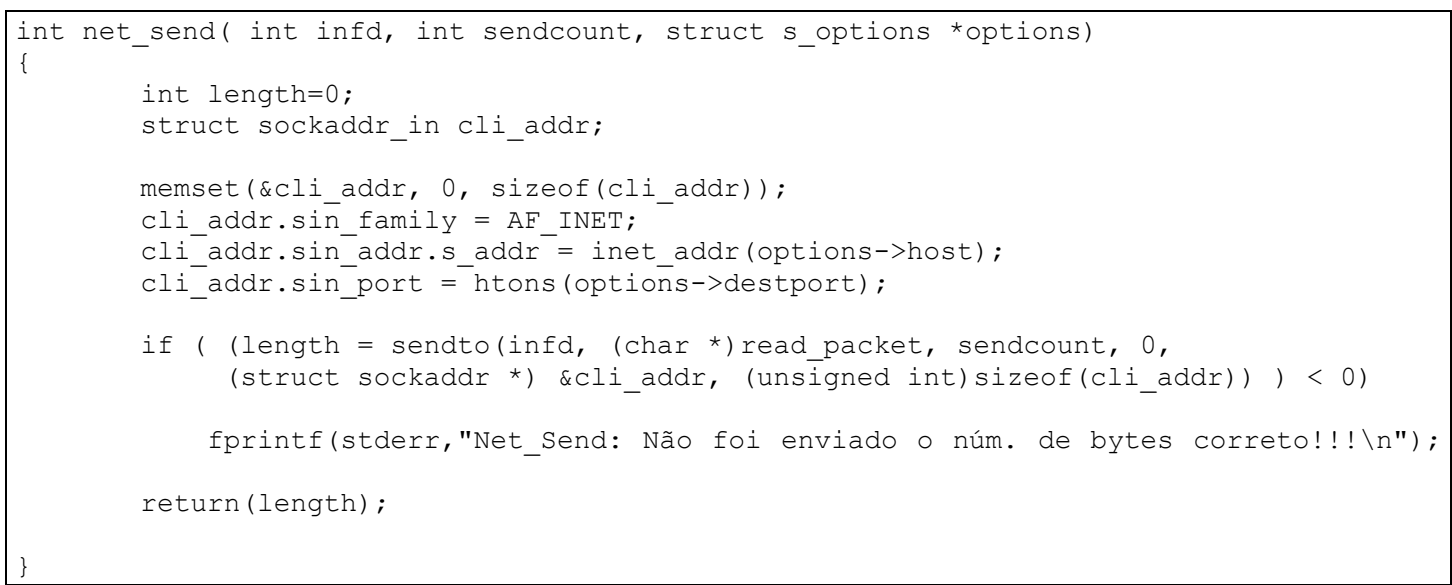

(b)

Figura 6.4 - Pseudo-código das funções de recepção (a) e transmissão (b) de pacotes TS.

A análise do cabeçalho dos pacotes TS é de fundamental importância para que seja identificada a presença de uma amostra do PCR nos pacotes TS, gravados 
Especificação dos módulos do framework para testes e avaliação do sincronismo

no buffer de análise. Para investigar os cabeçalhos dos pacotes TS e encontrar amostras do PCR, foi implementada uma função que tem um único objetivo, procurar alguma amostra do PCR dentro do buffer de análise, retornando o byte que inicia o pacote TS que contém a amostra. O pseudo-código dessa função é apresentado na figura 6.5 .

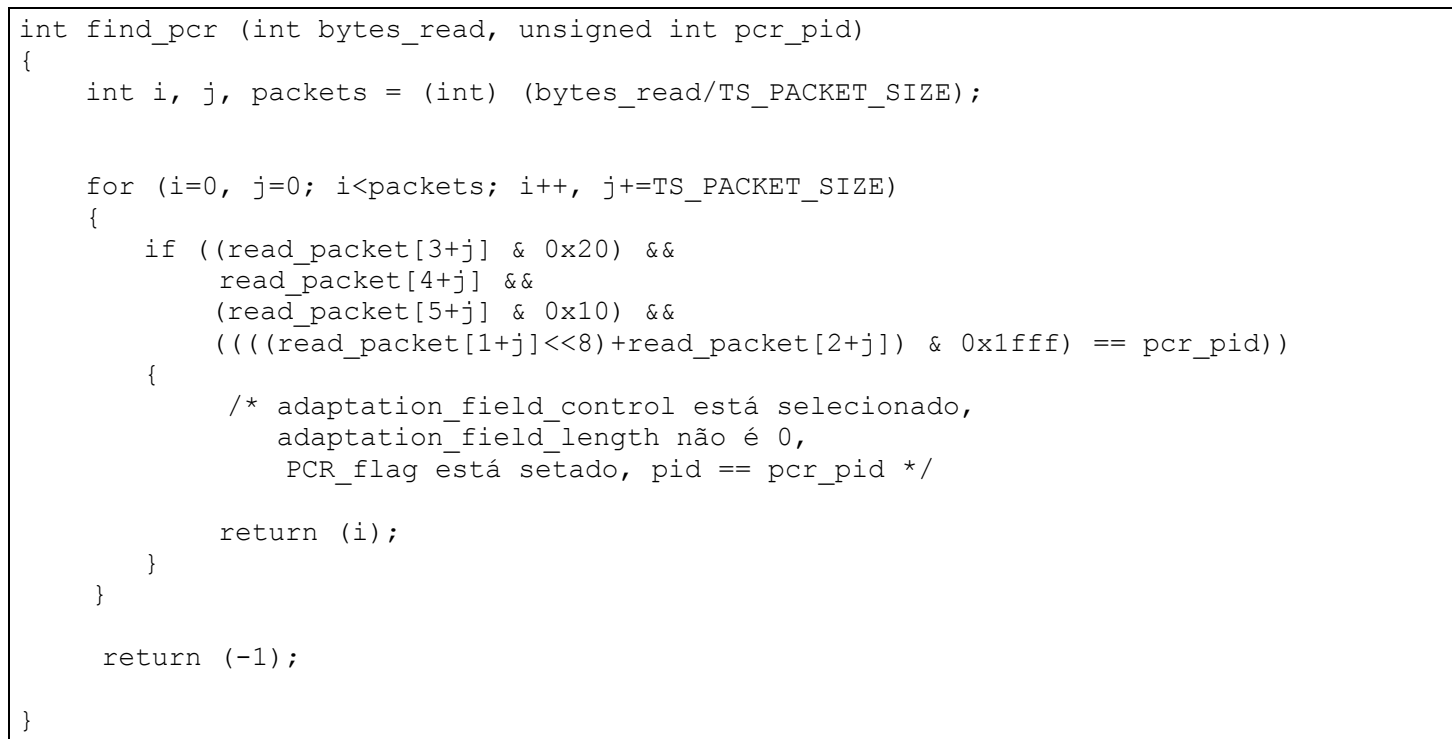

Figura 6.5 - Pseudo-código da função que procura uma amostra do PCR dentro de uma série de pacotes TS.

O pseudo-código da figura 6.5 mostra como é feita a análise do Fluxo de Transporte para um caso específico, a procura de uma amostra do PCR. Primeiro, calcula-se o número de pacotes TS que estão gravados no buffer de análise (variável packets). Pode-se, então, começar a procura pacote a pacote (loop) por três condições: se o campo adaptation_field_control do cabeçalho do pacote TS está selecionado, se o adaptation_field_length do campo de adaptação não é zero e se o PCR_Flag do campo de adaptação está selecionado. Ou seja, se o pacote TS possui um campo de adaptação de tamanho não nulo e que contém uma amostra do PCR.

Encontrada uma amostra do PCR no buffer de análise, procede-se com o cálculo da variação de atraso da amostra atual do PCR (PCR_Jitter). Para isso, primeiro, converte-se o valor da amostra do PCR para microssegundos (pseudocódigo na figura 6.6) e, em seguida, calcula-se a distância, em bytes e 
Especificação dos módulos do framework para testes e avaliação do sincronismo

microssegundos, entre a amostra atual e a imediatamente anterior, do PCR. Além disso, é calculada a taxa de leitura dos buffers do receptor (transport_rate), ou seja, registra-se o valor da taxa de decodificação e exibição do vídeo sendo utilizada no receptor para manter o sincronismo do fluxo de transporte. Na figura 6.7 é apresentado o pseudo-código da função de atualização dos parâmetros do sincronismo que calcula essas métricas.

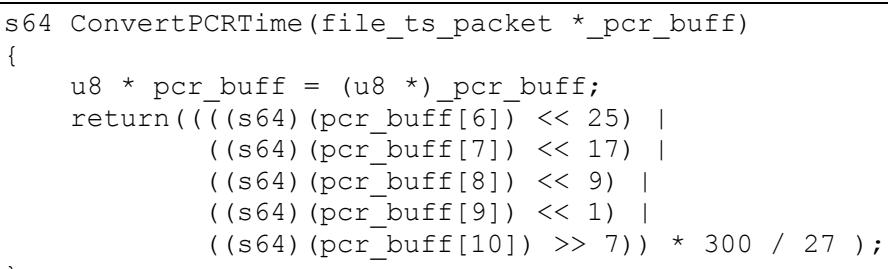

Figura 6.6 - Pseudo-código da função de conversão da amostra do PCR para microssegundos.

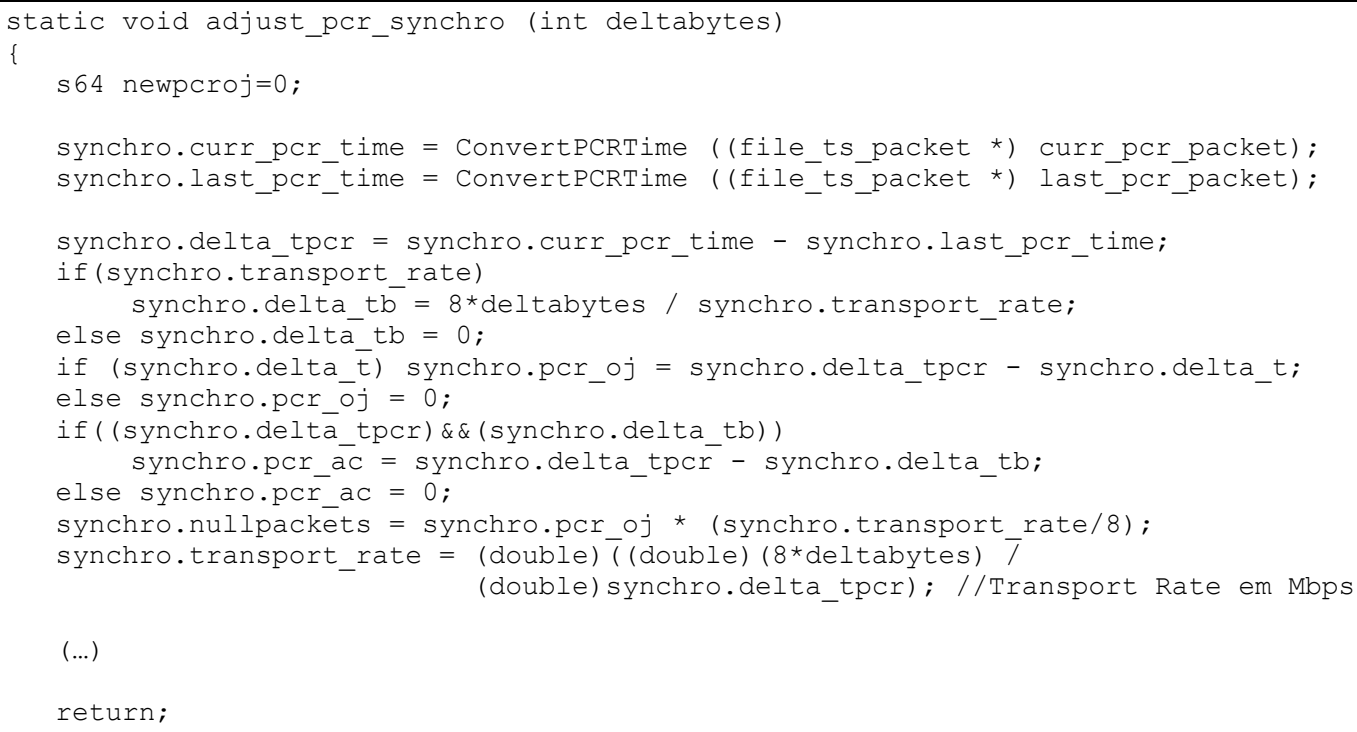

Figura 6.7 - Pseudo-código da função de ajuste dos parâmetros de sincronismo do

Fluxo de Transporte.

Para calcular a distância, em bytes, entre duas amostras do PCR é necessário contabilizar o número de bytes recebidos entre as duas ocorrências de amostras do PCR. Isso é feito no momento do recebimento de um pacote TS. Ou seja, sempre que são recebidos novos pacotes TS são procuradas amostras do PCR, caso uma amostra seja encontrada, o número de bytes até o início do pacote TS que contém o PCR é 
Especificação dos módulos do framework para testes e avaliação do sincronismo

registrado, caso não seja encontrada uma amostra, o número total de bytes dos novos pacotes recebidos é registrado. Essa contagem continua até que seja encontrada uma amostra do PCR, sendo que, nesse caso, o contador de bytes entre amostras do PCR é zerado.

As demais métricas calculadas na função da figura 6.7 (delta_t, delta_tpcr, delta_tb, etc) são fundamentais para a definição da variação de atraso para a amostra atual do PCR. Uma vez obtido o PCR_Jitter (variável pcr_oj) é possível determinar se a amostra do PCR está adiantada ou atrasada. Se PCR_Jitter for maior que zero (delta_tpcr maior que delta_t), a amostra do PCR está adiantado. Caso PCR_Jitter for menor que zero (delta_tpcr menor que delta_t), a amostra do PCR está atrasada. É necessário manter um histórico do PCR_Jitter para dar subsídios às decisões de outros algoritmos.

Conforme o diagrama de blocos da figura 6.3, quando a amostra do PCR estiver adiantada, pacotes nulos devem ser inseridos. $\mathrm{O}$ procedimento para inserir pacotes nulos é, basicamente, transmitir pelo socket de saída, quantas vezes forem necessárias, o conteúdo de um buffer que contenha um pacote nulo (na figura 6.8 é mostrado um pacote TS nulo).

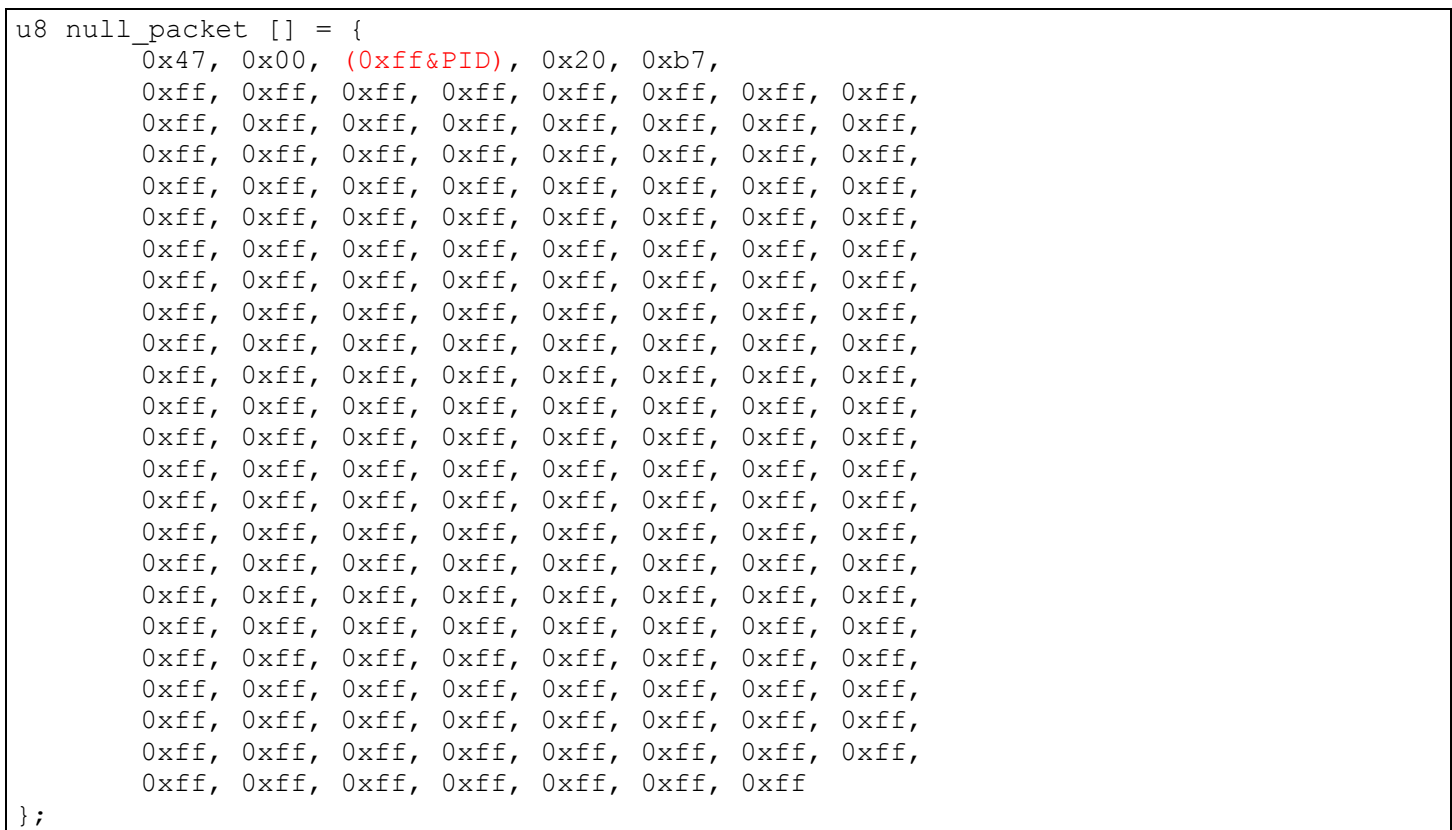




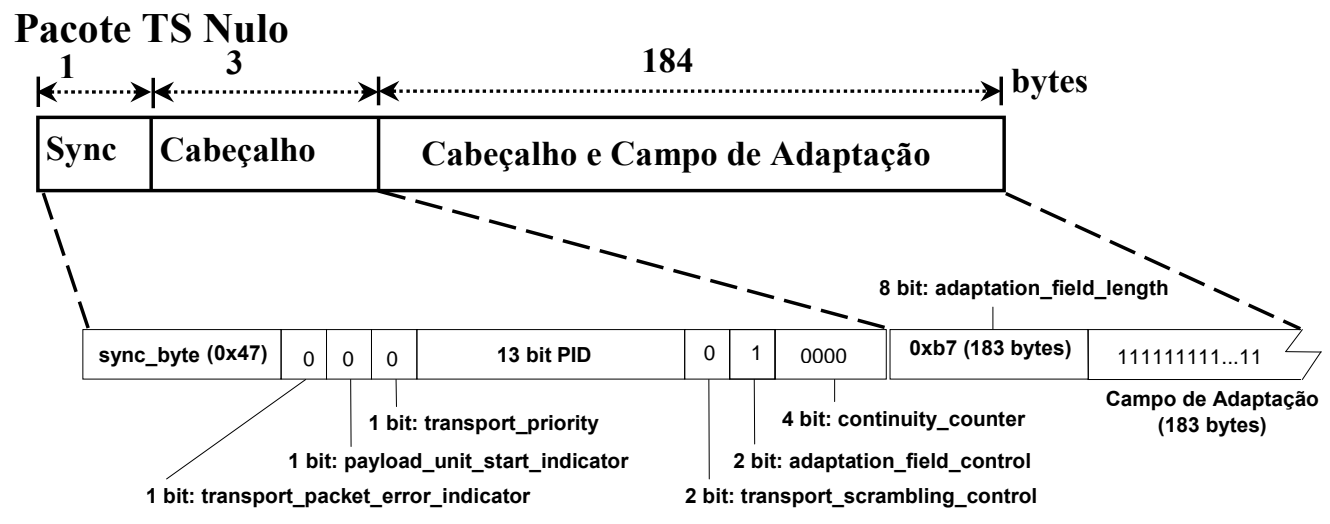

(b)

Figura 6.8 - Pacote TS Nulo, em hexadecimal (a) e esquemático (b).

A metodologia utilizada no bloco de inserção de pacotes nulos consiste em enviar o número de pacotes nulos correspondentes a diferença entre delta_tpcr e delta_t. Para isso, é fundamental obter o número de pacotes nulos necessários para preencher o atraso da amostra do PCR (variável synchro.nullpackets dividida pelo tamanho em bytes de um pacote nulo, ou seja, 188 bytes). $O$ procedimento utilizado para calcular o número de pacotes nulos consiste em efetuar a razão entre PCR_Jitter e a taxa de bits do fluxo de transporte (transport_rate em bytes/segundo). Ao enviar pacotes nulos, mantém-se inalterada a distância temporal entre amostras do PCR e, assim, o sincronismo é mantido no receptor. Após o envio dos pacotes nulos, pode ser enviado o bloco de pacotes TS que contém uma amostra do PCR.

O processo, como um todo, é um conjunto de pequenas tarefas para resolver um problema mais complexo. Para o melhor entendimento de todos os passos apresentados, foi elaborado um diagrama esquemático, mostrado na figura 6.9, que contém as diversas atividades necessárias para a ressincronização do fluxo de transporte por meio da inserção de pacotes nulos. 
Especificação dos módulos do framework para testes e avaliação do sincronismo

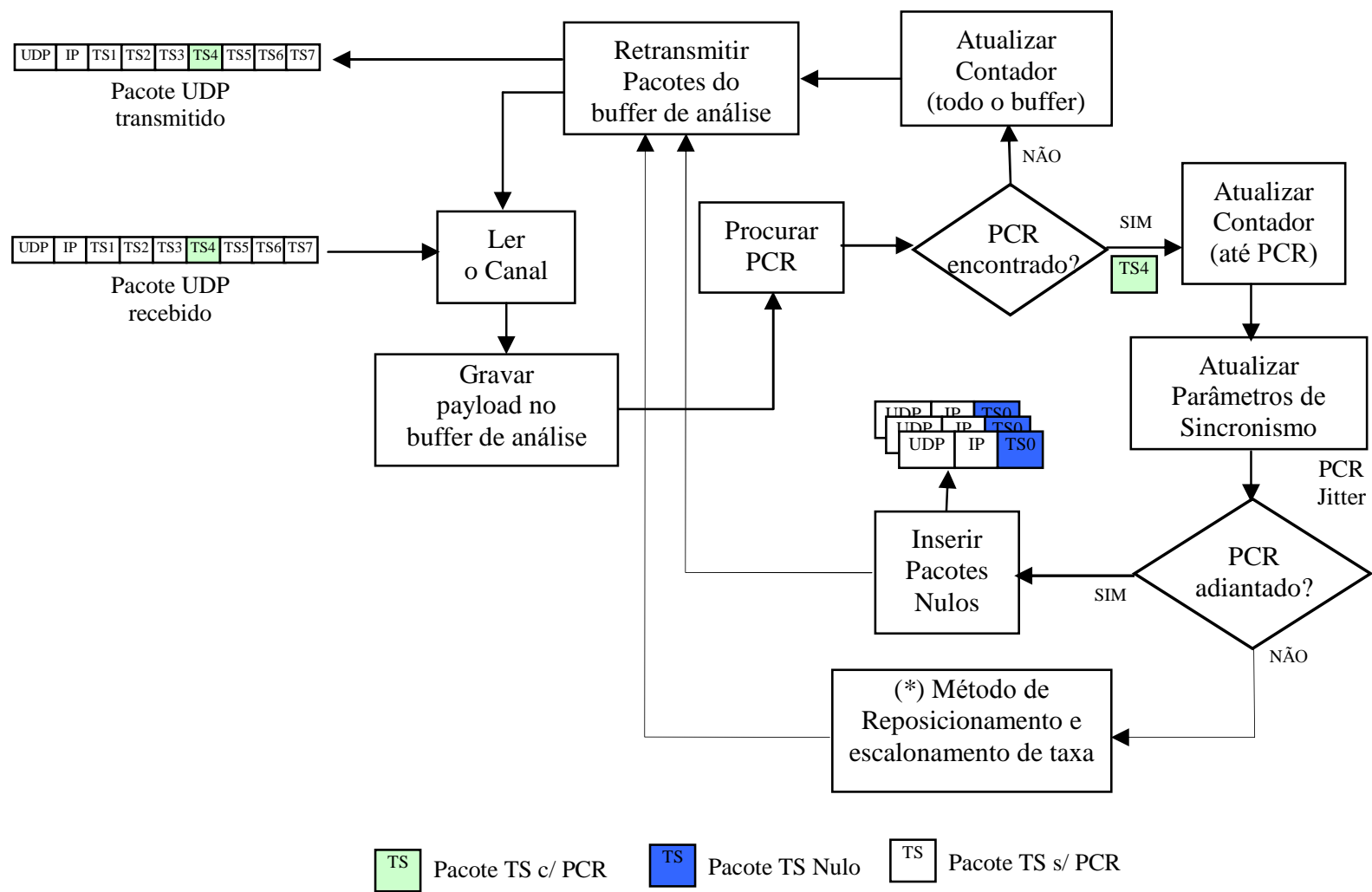

(*) Método descrito nas próximas seções e que não compõem o módulo de inserção de pacotes nulos.

Figura 6.9 - Diagrama Esquemático do Módulo de Inserção de Pacotes Nulos.

\subsubsection{Módulo de reposicionamento dos pacotes contendo amostras do PCR}

Para implementar o módulo de reposicionamento dos pacotes contendo amostras do PCR são especificados dois métodos: descarte de pacotes TS contendo informação de quadros B e requantização de slices de quadros do vídeo codificado.

A idéia central desse módulo é reduzir o número de bytes entre duas amostras do PCR, de forma a reduzir os impactos de atrasos em sua chegada, conforme destacado na seção 5.2. Verifica-se facilmente que, em ambos os casos o objetivo é alcançado. No primeiro método, pacotes TS são descartados diretamente e, por isso, o número de bytes entre amostras do PCR diminui, conseqüentemente, diminuindo também a distância temporal entre amostras do PCR. No segundo método, é reduzido o número de bytes entre amostras do PCR, aumentando a taxa de compressão do vídeo transmitido. Como o vídeo de teste utilizado foi codificado em MPEG2, o mecanismo escolhido para aumentar a taxa de compressão foi a requantização dos 
Especificação dos módulos do framework para testes e avaliação do sincronismo

coeficientes da DCT (SILVEIRA, 2001; BENOIT, 1997; HASKELL ET AL, 1997; XIN ET AL, 2005). As razões principais para a escolha da requantização foram sua simplicidade e rapidez. Além disso, com a requantização, não é necessária a descompressão e a recompressão do vídeo e o processo é todo feito no domínio das freqüências.

Os dois métodos têm implementação e complexidade diferentes e a comparação entre os dois mecanismos torna-se relevante para a avaliação de desempenho da ressincronização no âmbito do framework. Essa comparação é feita em dois momentos, nesta seção, onde são descritas as implementações de cada um dos métodos, e, no próximo capítulo, onde será avaliada a influência de cada um deles nos resultados experimentais.

\subsubsection{Método por descarte de pacotes TS de quadros B}

A idéia central do primeiro método, descarte de pacotes TS contendo informação de quadros $\mathrm{B}$, é descartar as informações menos relevantes do vídeo transmitido para compensar o atraso na chegada das amostras do PCR. Quando é identificada variação de atraso negativa das amostras do PCR (delta_t maior que delta_tpcr), os bytes excedentes (diferença entre delta_tpcr e delta_t convertida para número de bytes, por meio da divisão pela taxa de bits do Fluxo de Transporte) devem ser eliminados por meio do descarte de informações de quadros B subseqüentes. $\mathrm{O}$ descarte de informações de pacotes TS posteriores tenta compensar desequilíbrios causados por parâmetros externos. Ou seja, esse método é reativo e utiliza as informações de variação de atraso nas amostras do PCR para estimar a influência desses parâmetros externos, principalmente com referência à variação de atraso.

A especificação desse método baseia-se essencialmente nas funções descritas na seção anterior. Entretanto, foi necessário desenvolver funções adicionais para solucionar problemas específicos. Por exemplo, para descartar os pacotes corretamente, é imprescindível que seja identificado o tipo de quadro que está sendo transmitido por um determinado pacote TS. Além disso, o descarte de pacotes de quadros B não deveria ser concentrado num único slice ou macrobloco, pois isso poderia degradar muito a qualidade de um determinado quadro B. Para tornar o 
Especificação dos módulos do framework para testes e avaliação do sincronismo

descarte aleatório de forma que descartes consecutivos não ocorressem no mesmo slice, foi especificado um mecanismo de controle do descarte de pacotes.

Para identificar o quadro que está sendo transmitido num determinado instante, é necessário identificar os pacotes que contenham os inícios de quadros. É possível descobrir o tipo de quadro que segue esse cabeçalho por meio de informações contidas nos picture header dentro dos pacotes TS. Para isso, torna-se necessário buscar, em cada pacote TS, um picture_start_code, ou seja, a seguinte seqüência em hexadecimal 0x00 0x00 0x01 0x00. Tendo sido, então, implementada uma função que executasse essa tarefa. O pseudo-código dessa função é apresentado na figura 6.10 .

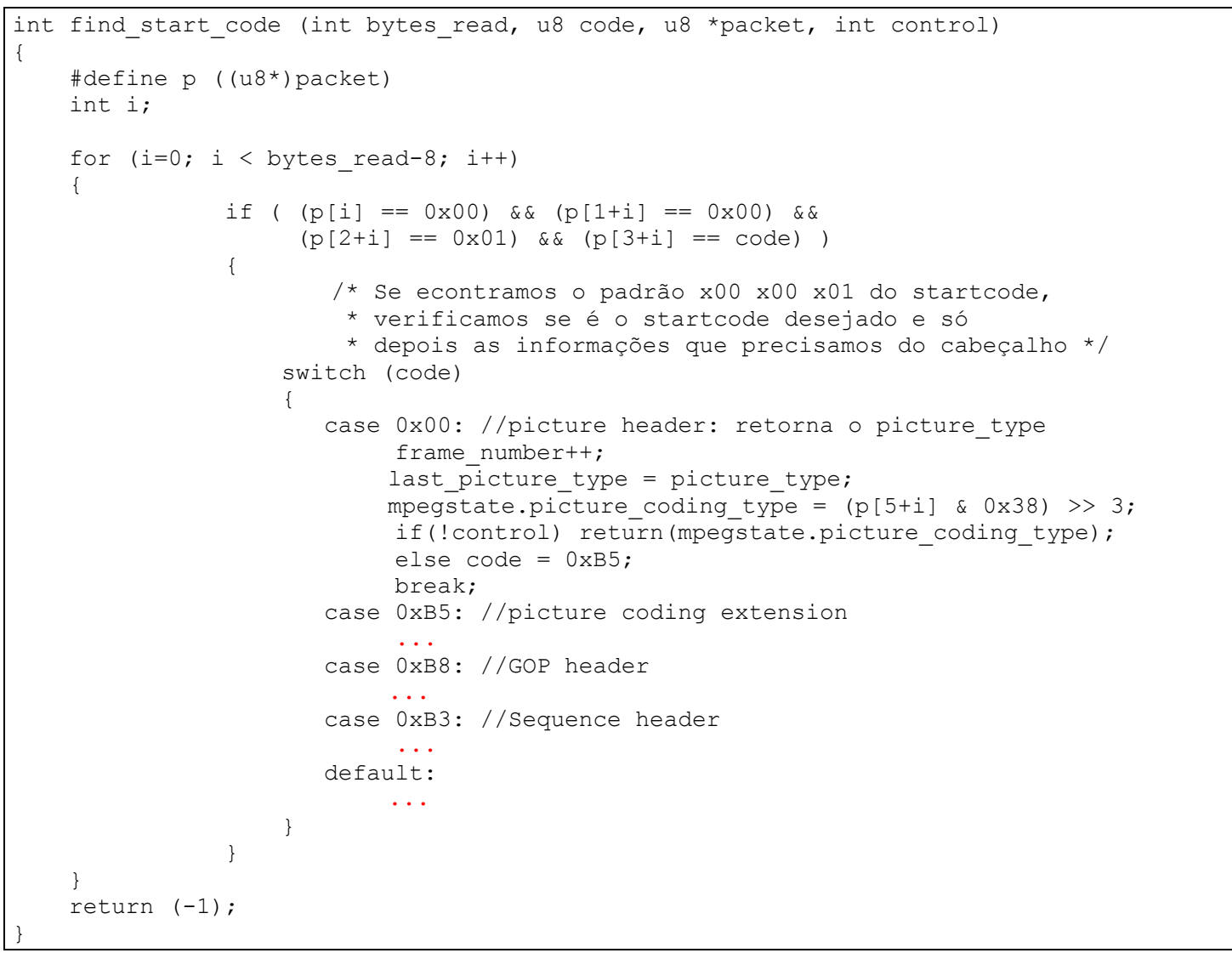

Figura 6.10 - Pseudo-código da função que identifica o tipo de quadro.

O mecanismo de descarte de pacotes de quadros B é implementado por meio de manipulações diretas sobre os dados dos pacotes armazenados no buffer de análise. Ou seja, apagando um determinado pacote TS do buffer de análise ou deixando de transmiti-lo está sendo efetuado, na verdade, o descarte desse pacote. 
Para não concentrar os descartes em determinadas regiões do vídeo, foi introduzido um mecanismo de descarte aleatório de pacotes, onde o número de pacotes a serem descartados, a cada momento, é gerado aleatoriamente a cada iteração do algoritmo (variável random). Na figura 6.11 é mostrado o pseudo-código para a função que implementa o descarte de pacotes de quadros B e o mecanismo que controla quando os descartes devem ocorrer.

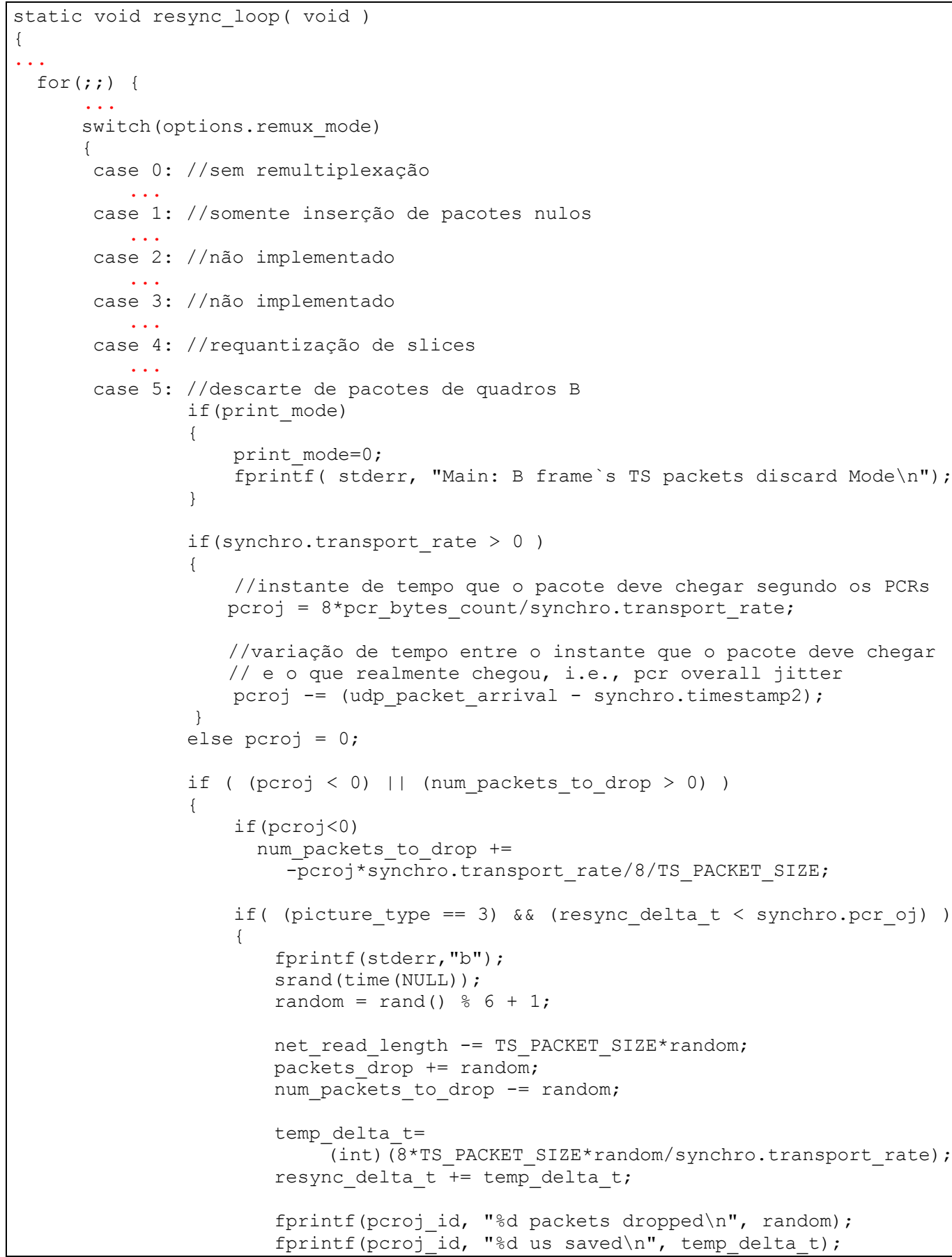


Especificação dos módulos do framework para testes e avaliação do sincronismo

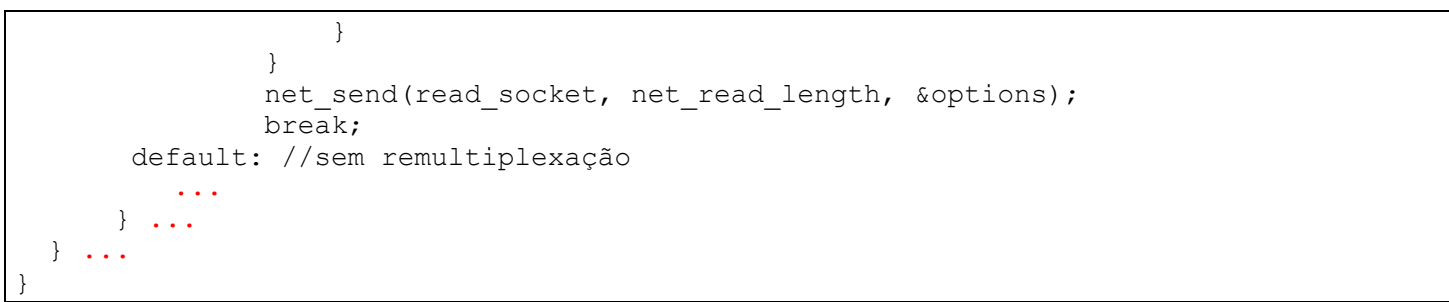

Figura 6.11 - Pseudo-código que implementa e controla o descarte de pacotes TS de quadros B.

\subsubsection{Método por Requantização de Slices do Vídeo Comprimido}

O segundo método, a requantização de coeficientes da DCT do vídeo multiplexado no Fluxo de Transporte, é mais complexo, pois envolve parâmetros de codificação do vídeo. Além disso, para requantizar o vídeo, torna-se necessário demultiplexá-lo do fluxo de transporte, de forma a possibilitar sua manipulação. Por outro lado, para retransmitir o vídeo é preciso inserí-lo novamente em pacotes TS, ou seja, multiplexá-lo novamente no Fluxo de Transporte.

Antes de descrever como foi implementado o segundo método, são introduzidos alguns conceitos básicos sobre a requantização no contexto dos métodos de compressão de vídeo baseados na transformada discreta de co-senos (DCT).

\subsection{Conceitos Básicos sobre Requantização no MPEG2}

Como pode ser verificado na literatura (SILVEIRA, 2001; BENOIT, 1997; HASKELL ET AL, 1997; XIN ET AL, 2005), o MPEG2 utiliza uma série de mecanismos para reduzir a redundância espacial e temporal dos quadros do vídeo sem compressão.

Os componentes R, G, e B de cada pixel do vídeo, são convertidos, primeiramente, em valores de luminância $(\mathrm{Y})$ e crominância $(\mathrm{Cr}$ e $\mathrm{Cb}$ ). Após essa conversão, cada quadro do vídeo é dividido em estruturas menores: slices, macroblocos e blocos. Cada bloco, geralmente, representa uma área de 8x8 pixels, um conjunto de blocos (4 blocos $\mathrm{Y}, 1 \mathrm{Cr}$ e $1 \mathrm{Cb}$, por exemplo) forma macroblocos, um conjunto subseqüente de macroblocos forma um slice, e a seqüência de vários slices forma, finalmente, um quadro do vídeo. Cada bloco é submetido a transformada discreta de co-senos (DCT) e depois quantizado. A quantização 
Especificação dos módulos do framework para testes e avaliação do sincronismo

consiste na divisão de cada coeficiente do bloco por um valor da matriz de quantização. Essa matriz possui um elemento associado a cada posição do bloco. As mudanças dos valores da matriz de quantização resultam na alteração da granularidade dos coeficientes quantizados. Ou seja, quanto maior o valor estabelecido para um elemento da matriz de quantização, menor será o coeficiente quantizado. Como poderá ser verificado no decorrer dos próximos parágrafos, o aumento dos valores da matriz de quantização diminui o número de códigos necessários para representar um bloco. Ao final dessa etapa, cada posição do bloco encontra-se associada a um coeficiente quantizado.

O processo segue com a codificação RLE (Run Level Encoding). Primeiro, efetua-se um rearranjo dos coeficientes do bloco denominado "zig-zag scan", de forma a tirar proveito de seqüências de coeficientes nulos. Após o "zig-zag scan", o bloco torna-se uma seqüência de 64 coeficientes e não mais uma matriz de 8x8 pixels. Codifica-se, então, seqüências de zeros e coeficientes como pares de números (run, level), onde run é o número de zeros que precedem um coeficiente da DCT e level é o seu valor. Com a codificação RLE, nota-se a importância da quantização para a compressão do vídeo. Quanto maior os valores da matriz de quantização, maior número de coeficientes nulos estarão presentes e, portanto, o número de pares (run, level) será menor. A requantização tem o objetivo de modificar os elementos da matriz de quantização, para obter maiores taxas de compressão, e conseqüentemente, menores taxas de bits na transmissão.

Finalmente, cada par (run, level) é associado a um código binário específico designado de acordo com um estudo de entropia dos pares (run, level) possíveis (códigos de Huffman). Essa etapa é denominada VLC (Variable Length Coding), pois os códigos associados a cada par (run, level) têm tamanho variável. Tanto a codificação VLC, quanto a RLE, geram informações que são enviadas no cabeçalho dos fluxos elementares de vídeo, por exemplo: A matriz de quantização utilizada para quantizar os blocos também é transmitida no cabeçalho da Seqüência de Vídeo. Para exemplificar o processo descrito acima, a figura 6.12 mostra a codificação de um bloco. 
Especificação dos módulos do framework para testes e avaliação do sincronismo

Bloco com 8x8 pixels

Matriz dos Coeficientes da DCT

\begin{tabular}{|r|r|r|r|r|r|r|r|}
\hline 132 & 136 & 138 & 140 & 144 & 145 & 147 & 155 \\
\hline 136 & 140 & 140 & 147 & 140 & 148 & 155 & 156 \\
\hline 140 & 143 & 144 & 148 & 150 & 152 & 154 & 155 \\
\hline 144 & 144 & 146 & 145 & 149 & 150 & 153 & 160 \\
\hline 150 & 152 & 155 & 156 & 150 & 145 & 144 & 140 \\
\hline 144 & 145 & 146 & 148 & 143 & 158 & 150 & 140 \\
\hline 150 & 156 & 157 & 156 & 140 & 146 & 156 & 145 \\
\hline 148 & 145 & 146 & 148 & 156 & 160 & 140 & 145 \\
\hline
\end{tabular}

\begin{tabular}{|r|r|r|r|r|r|r|r|}
\hline 156 & -17 & -4 & -2 & -4 & 3 & 1 & -6 \\
\hline-14 & -24 & 8 & -8 & 5 & -2 & -3 & 2 \\
\hline-9 & -7 & 0 & 2 & 1 & -3 & 2 & -2 \\
\hline-8 & 8 & -1 & -3 & -5 & 5 & -2 & -1 \\
\hline-2 & 2 & -3 & 2 & 8 & -9 & 5 & 4 \\
\hline 3 & -4 & 7 & -6 & -2 & 1 & -2 & 3 \\
\hline-5 & -7 & -6 & 11 & 1 & -6 & 5 & 0 \\
\hline 4 & 13 & -4 & -5 & 1 & 2 & -4 & 2 \\
\hline
\end{tabular}

Matriz de Quantização

Matriz dos Coeficientes

$\mathbf{L}(\mathbf{i}, \mathbf{j})=\mathbf{D C} \mathbf{T}(\mathbf{i}, \mathbf{j})$ da DCT Quantizados $/ \mathbf{Q S}(\mathbf{i}, \mathbf{j})$

\begin{tabular}{|r|r|r|r|r|r|r|r}
\hline 8 & 16 & 19 & 22 & 26 & 27 & 29 & 34 \\
\hline 16 & 16 & 22 & 24 & 27 & 29 & 34 & 37 \\
\hline 19 & 22 & 26 & 27 & 29 & 34 & 34 & 38 \\
\hline 22 & 22 & 26 & 27 & 29 & 34 & 37 & 40 \\
\hline 22 & 26 & 27 & 29 & 32 & 35 & 40 & 48 \\
\hline 26 & 27 & 29 & 32 & 35 & 40 & 48 & 58 \\
\hline 26 & 27 & 29 & 34 & 38 & 46 & 56 & 69 \\
\hline 27 & 29 & 35 & 38 & 46 & 56 & 69 & 83 \\
\hline
\end{tabular}$\quad$\begin{tabular}{r|r|r|r|r|r|r|r|r|}
\hline 20 & -1 & 0 & 0 & 0 & 0 & 0 & 0 \\
\hline-1 & -2 & 0 & 0 & 0 & 0 & 0 & 0 \\
\hline 0 & 0 & 0 & 0 & 0 & 0 & 0 & 0 \\
\hline 0 & 0 & 0 & 0 & 0 & 0 & 0 & 0 \\
\hline 0 & 0 & 0 & 0 & 0 & 0 & 0 & 0 \\
\hline 0 & 0 & 0 & 0 & 0 & 0 & 0 & 0 \\
\hline 0 & 0 & 0 & 0 & 0 & 0 & 0 & 0 \\
\hline 0 & 0 & 0 & 0 & 0 & 0 & 0 & 0 \\
\hline
\end{tabular}

RLE

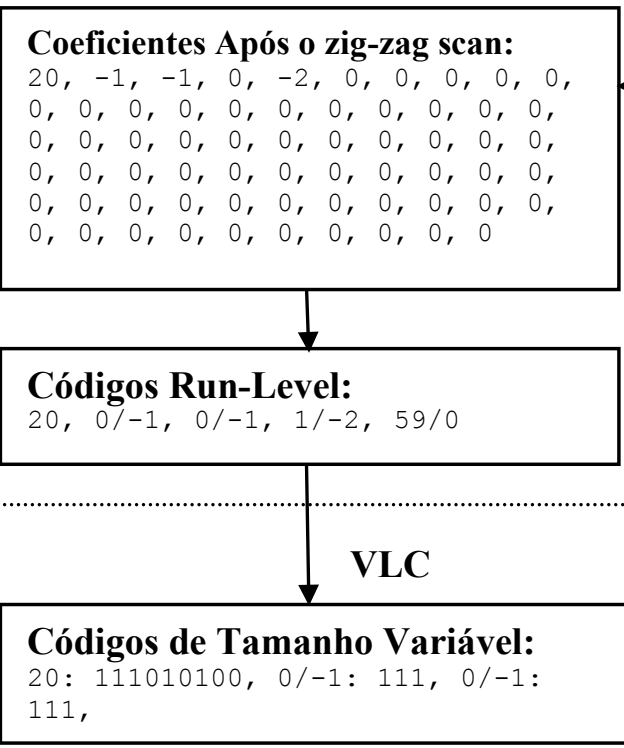

Figura 6.12 - Exemplo da codificação de um bloco de vídeo com o MPEG2.

A decodificação segue o processo inverso da codificação. Ou seja, encontrado um bloco qualquer do vídeo são identificados os códigos de tamanho variável que o compõem (VLD, Variable Length Decoding) e são descobertos os pares (run, level) associados (RLD, Run-Level Decoding). Os pares (run, level) são, 
então, transformados novamente em seqüências de coeficientes da DCT, que são, em seguida, dequantizados e voltam aos seus valores originais. Finalmente, aplica-se a transformada discreta de co-senos inversa (IDCT) e, assim, o bloco retoma os valores de luminância ou crominância. Os passos do processo de codificação e decodificação são mostrados na figura 6.13.

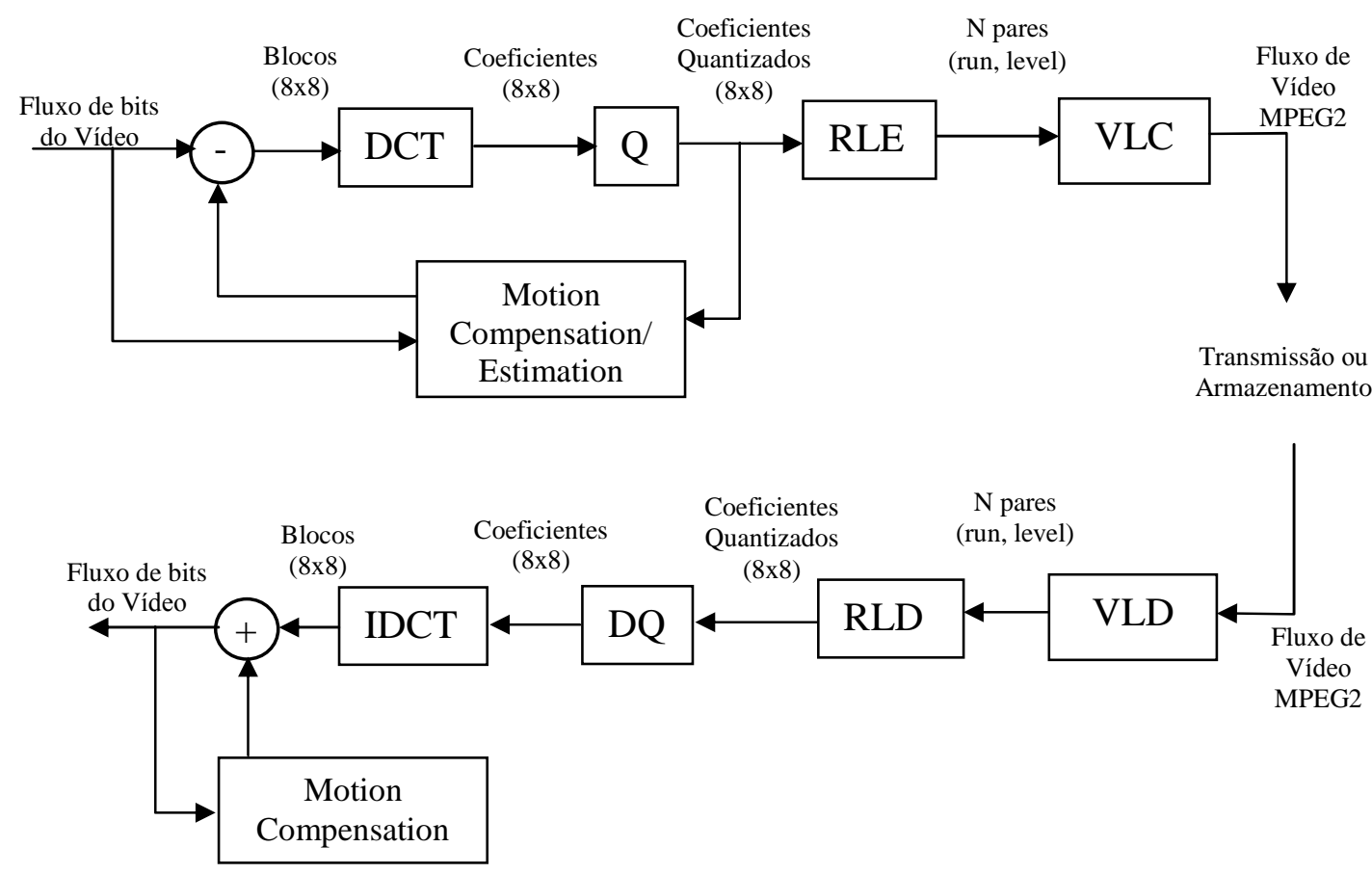

$$
\begin{array}{ll}
\text { DCT: Transformada Discreta de Cossenos. } & \text { Q: Quantização. } \\
\text { IDCT: Transformada Discreta de Cossenos Inversa. } & \text { DQ: Dequantização. } \\
\text { RLE: Run Level Encoding. } & \text { VLC: Variable Length Coding. } \\
\text { RLD: Run Level Decoding. } & \text { VLD: Variable Length Decoding. }
\end{array}
$$

Figura 6.13 - Processo simplificado de codificação e decodificação no MPEG2.

A requantização consiste em alterar a matriz de quantização original, multiplicando seus valores por uma constante pré-definida $k$, e reaplicar a quantização aos coeficientes da DCT de cada bloco. Ou seja, efetua-se a dequantização dos coeficientes, requantizando-os com outra matriz de quantização. A definição do valor de $k$ é de fundamental importância, pois é por meio dele que se altera a compressão dos blocos e, conseqüentemente, do vídeo como um todo. 
Especificação dos módulos do framework para testes e avaliação do sincronismo

Conforme a figura 6.12, a quantização é feita por meio da divisão dos coeficientes da DCT do bloco pelos respectivos valores da matriz de quantização. Portanto, quanto maiores os valores de cada elemento da matriz de quantização, menores serão os coeficientes resultantes. Como pode ser evidenciado pela figura 6.12, a quantização resulta em vários coeficientes nulos. Quanto maior a constante $\mathrm{k}$, maior a probabilidade de zeros estarem presentes nos blocos quantizados e, assim, maior a compressão, pois os zeros em seqüência serão todos substituídos na codificação RLE. Em outras palavras, ao invés de vários pares (run, level), o bloco terá poucos deles e assim o bloco poderá ser representado por menos bits, aumentando assim a compressão. Esse processo, entretanto, resulta em menor qualidade da imagem, já que a quantização considera somente o valor inteiro da divisão, desprezando o resto.

O processo de requantização pode ser implementado por meio do cascateamento de um decodificador e um codificador, eliminando-se algumas opções de cada um deles. Por exemplo, não é necessário aplicar transformadas (DCT e IDCT), ou seja, o processo pode ser feito todo no domínio das freqüências. Além disso, para quadros $\mathrm{P}$ ou $\mathrm{B}$ não se faz necessário implementar compensação de movimento, pois os vetores de movimento permanecem inalterados. O processo de requantização introduz o chamado "erro de requantização", devido ao cascateamento de decodificador e codificador e, em conseqüência, há uma redução de qualidade. $\mathrm{Ou}$ seja, paga-se um preço quando reduzimos o número de bytes do vídeo por meio da requantização, a qualidade objetiva do vídeo degrada-se. A figura 6.14 mostra os blocos que constituem um requantizador.

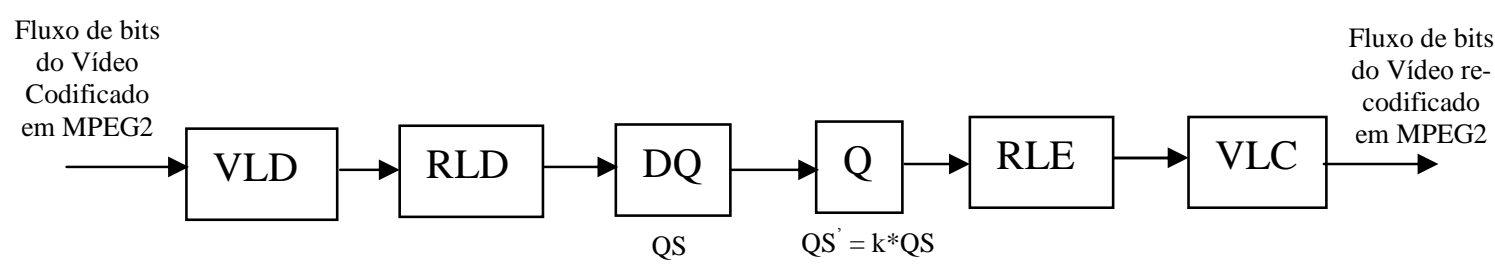

Figura 6.14 - Diagrama de Blocos do Requantizador. 
Especificação dos módulos do framework para testes e avaliação do sincronismo

\subsection{Especificação do Método por Requantização de Slices do Vídeo Comprimido}

A requantização de vídeos codificados em MPEG2 já foi amplamente discutida e compreendida no meio acadêmico (SILVEIRA, 2001; XIN ET AL, 2005). Por conseguinte, o código fonte de vários requantizadores pode ser obtido na internet. Para a implementação do método por requantização de slices do vídeo comprimido, uma dessas implementações foi escolhida e adaptada ao propósito do módulo de reposicionamento de pacotes contendo amostras do PCR.

A implementação selecionada é baseada no Test Model 5 (TEST MODEL 5, 1993) do MSSG (MPEG Software Solutions Group) ${ }^{41}$, uma solução baseada no código utilizado para os testes de conformidade de seqüências de vídeo comprimido à recomendação H.262 (ISO 13818-3, 1994). O código fonte do requantizador foi desenvolvido por uma empresa canadense de software chamada Metakine ${ }^{42}$ e está disponível na internet para o ambiente windows, com entrada e saída por meio de arquivos em disco.

O código fonte utilizado foi, então, portado para o ambiente linux e inserido no módulo de reposicionamento de pacotes contendo amostras do PCR. No entanto, algumas adaptações foram necessárias para utilizar as funcionalidades do requantizador. Como pode ser observado na seção 6.3.1, os pacotes TS são armazenados em um buffer de análise após seu recebimento. Por isso, o requantizador deve ler os dados de entrada armazenados no buffer de análise e sua saída deve ser disponibilizada em um buffer de saída para que a função de retransmissão de pacotes TS possa reenviar o vídeo requantizado. Além dessas alterações, outras foram necessárias, pois o requantizador não trata vídeos encapsulados em pacotes TS e, tampouco, em pacotes PES. Por conseguinte, foi necessário desenvolver um demultiplexador para selecionar os pacotes TS com vídeo, retirar os cabeçalhos desses pacotes e, caso necessário, retirar os cabeçalhos de pacotes PES. A saída do demultiplexador é o fluxo elementar, codificado em MPEG2, armazenado em um buffer. A partir daí, o requantizador pode ser utilizado

\footnotetext{
${ }^{41}$ MSSG. Disponível em : <http://www.mpeg.org/MPEG/MSSG/tm5>. Acesso em: 30 jan. 2006.

${ }^{42}$ Metakine. Disponível em $:<\mathrm{http}: / /$ www.metakine.com/files/\$M2VRequantiser.tgz $>$. Acesso em: 30 jan. 2006.
} 
Especificação dos módulos do framework para testes e avaliação do sincronismo

para diminuir a taxa de bits e escrever o vídeo quantizado no buffer de saída. Além disso, o novo vídeo tem que ser retransmitido e para isso foi necessário desenvolver também um multiplexador para inserir o novo vídeo em pacotes TS e enviá-los para a retransmissão. Na figura 6.15 é apresentado um diagrama de blocos da implementação do método por requantização.

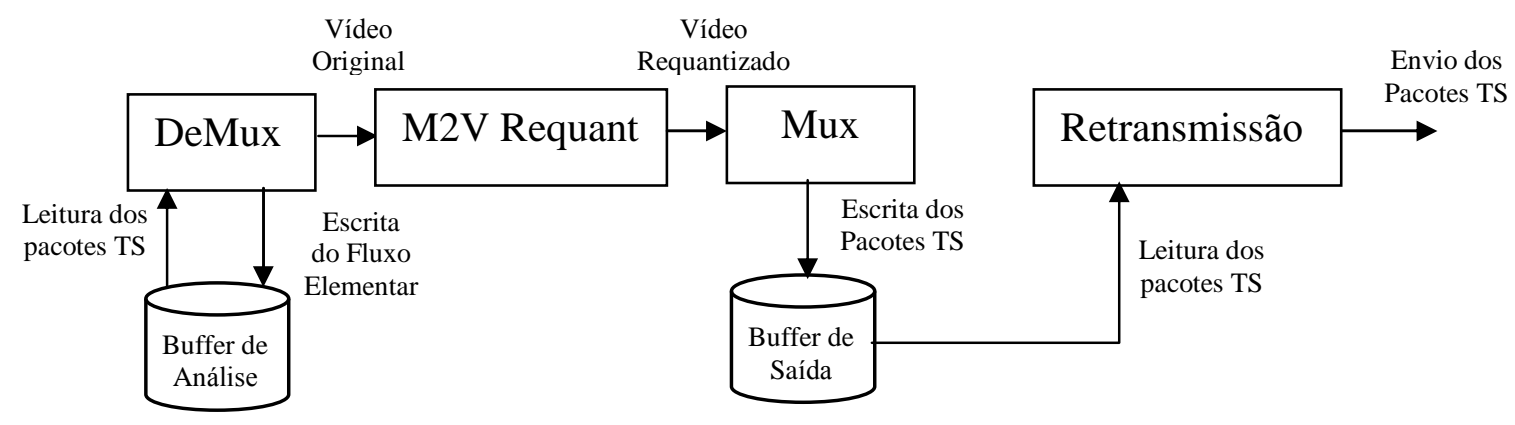

Figura 6.15 - Diagrama de Blocos do Método por Requantização.

As principais tarefas do demultiplexador consistem em selecionar determinados pacotes TS entre todos os pacotes TS recebidos, extrair seus campos de dados e escrevê-los no buffer de análise. Para selecionar os pacotes TS corretos, aqueles que contêm bytes do vídeo, o demultiplexador deve conhecer o PID específico do vídeo. Selecionados os pacotes corretos, os campos de dados são lidos e seus cabeçalhos desprezados, restando somente o fluxo elementar no buffer de análise. Além disso, deve ser verificado se o conteúdo dos pacotes TS não possui cabeçalhos de pacotes PES. Caso se constate a existência de cabeçalhos desses pacotes eles também devem ser desprezados. O pseudo-código da função que implementa a demultiplexação é apresentado na figura 6.16 (a).

A requantização segue os conceitos abordados na seção 6.3.2.2.1. No entanto, antes de efetuar a requantização, propriamente dita, o requantizador examina o fluxo elementar no intuito de encontrar o primeiro cabeçalho do primeiro slice. Após encontrá-lo, inicia-se o processo de requantização. Ou seja, o requantizador processa os bytes do fluxo elementar, interpretando os cabeçalhos dos slices e dos macroblocos, e ainda extrai informações sobre os blocos, para então iniciar o processo mostrado na figura 6.14. O código fonte que implementa a requantizador é 
extenso e será apresentado no anexo I desta dissertação, juntamente com as principais funções do módulo de ressincronismo.

O multiplexador, por sua vez, implementa tarefas opostas ao demultiplexador, ou seja, reconstrói os cabeçalhos dos pacotes TS, inserindo as informações necessárias (PID, número de seqüência, flags, e outros); insere o fluxo elementar nos campos de dados dos pacotes TS; e reconstrói os cabeçalhos de pacotes PES, quando necessário. Os bytes do fluxo elementar são lidos a partir de um buffer de saída preenchido pelo requantizador, sendo o valor do PID do vídeo previamente conhecido. Na figura 6.16 (b) é apresentado o pseudo-código do multiplexador.

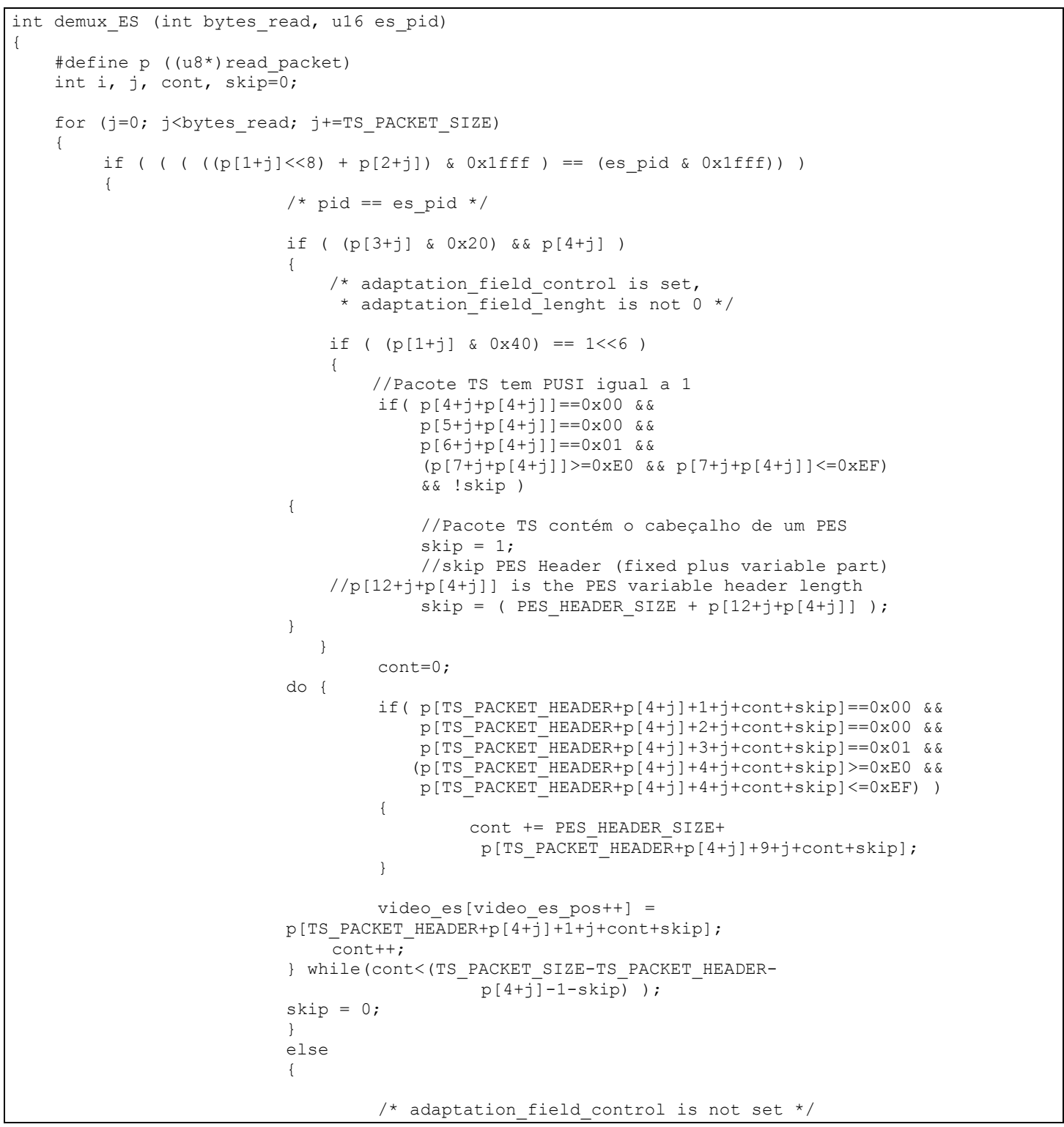




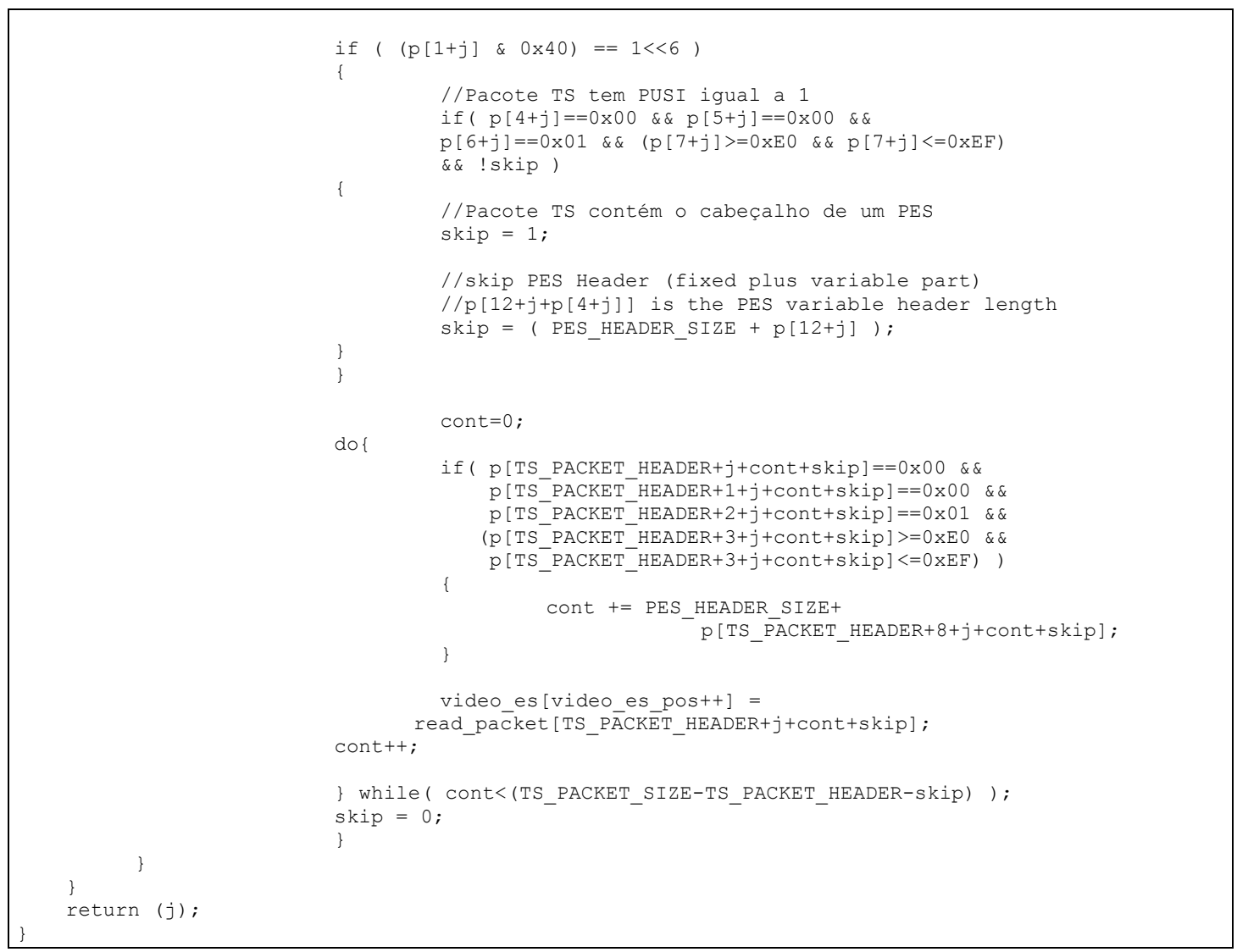

(a)

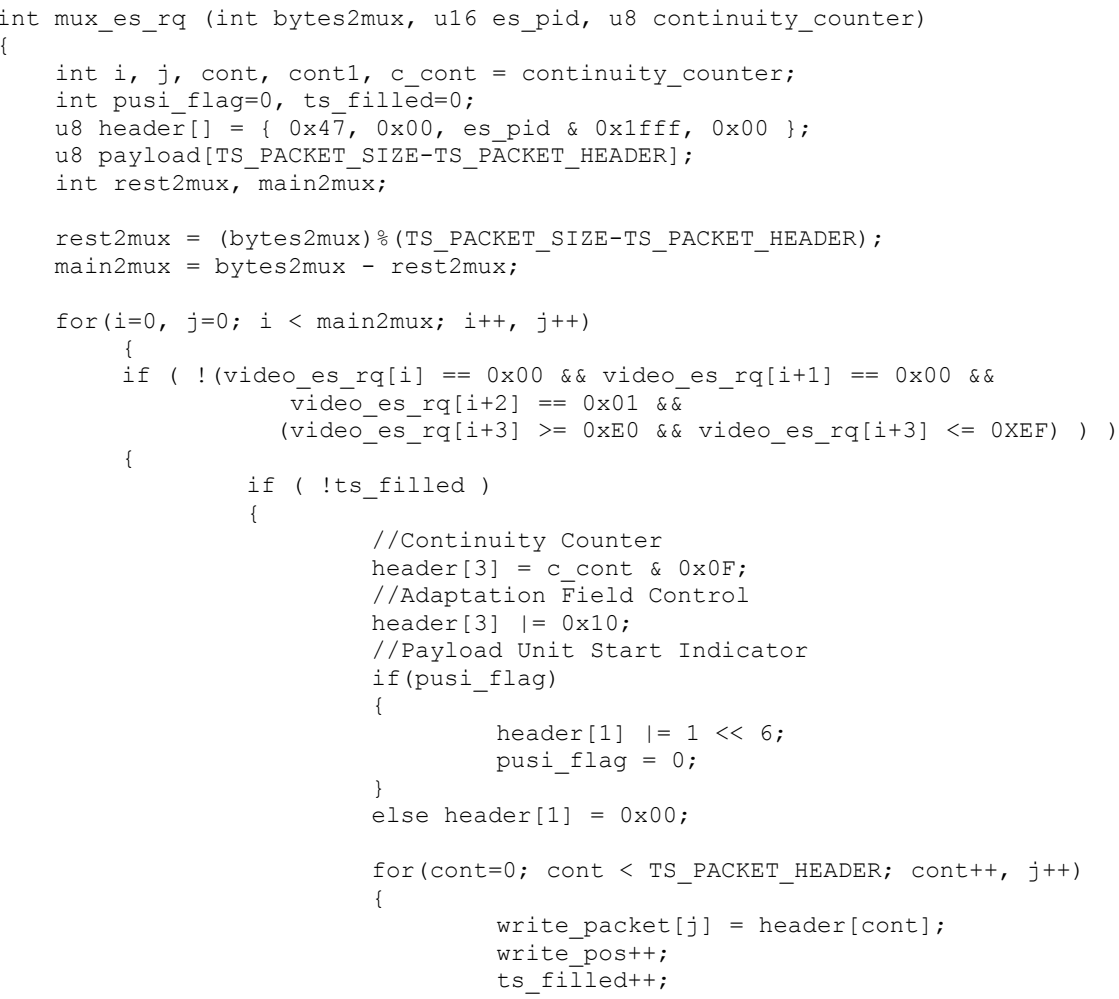




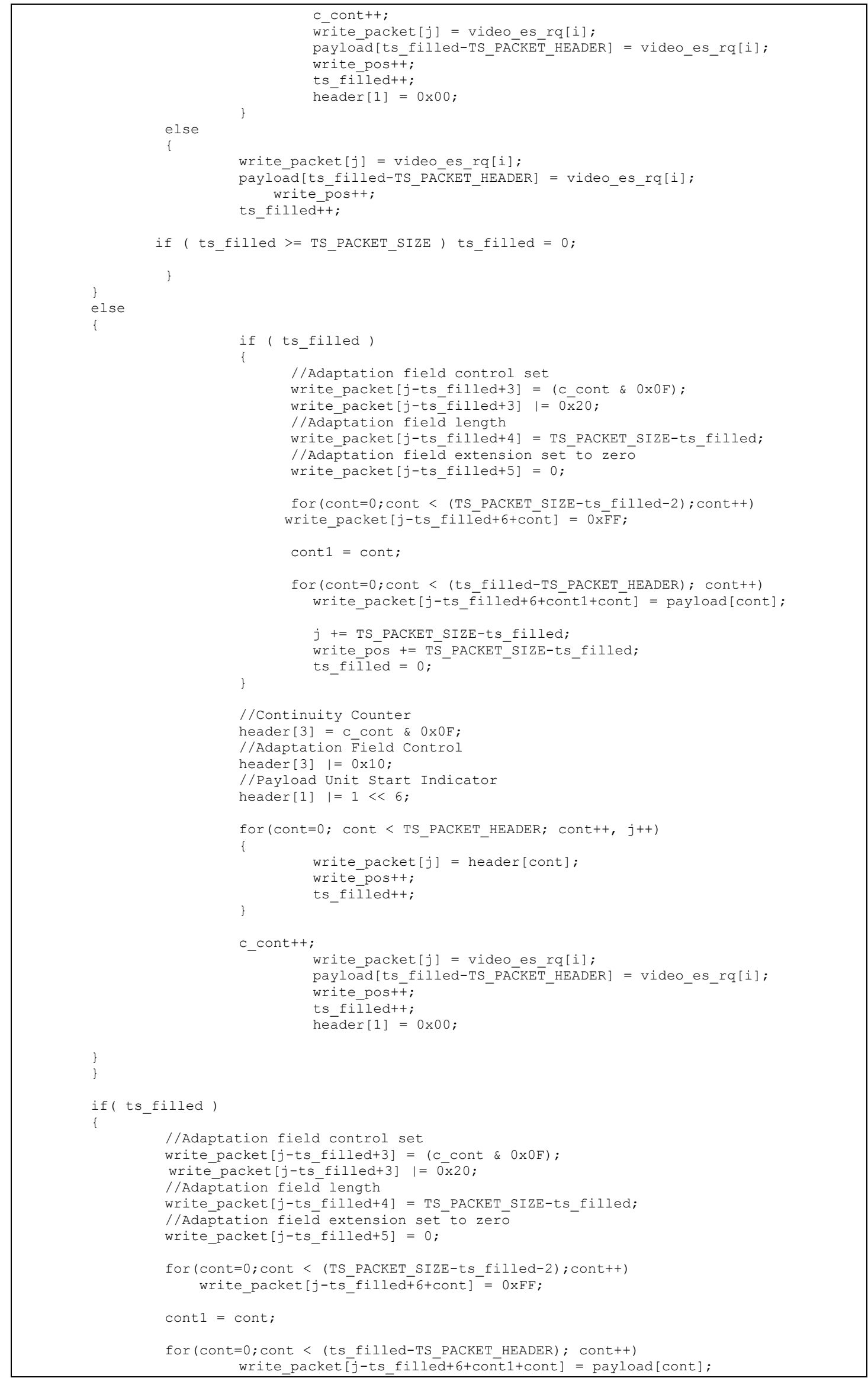


Especificação dos módulos do framework para testes e avaliação do sincronismo

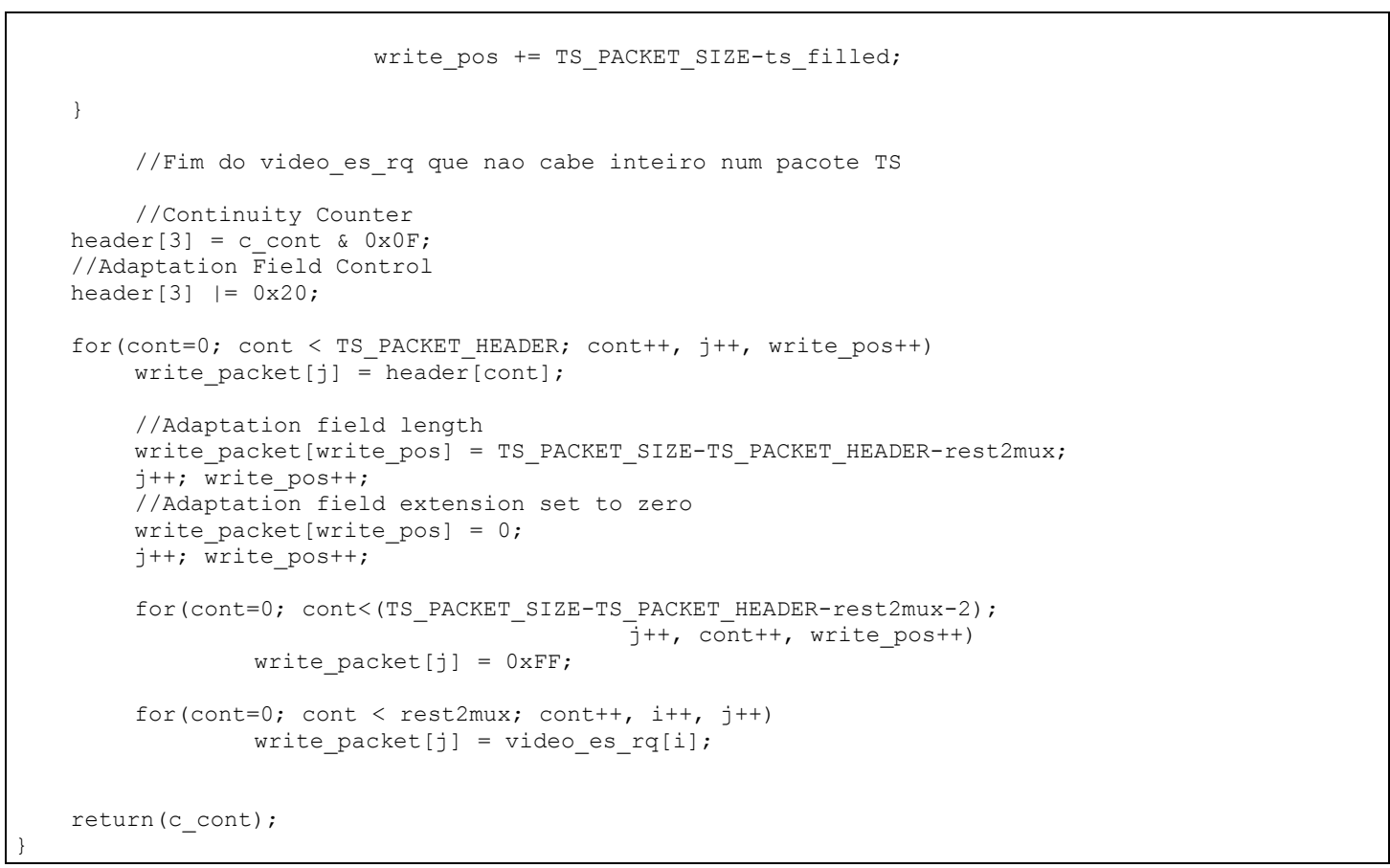

(b)

Figura 6.16 - Pseudo-código do Demultiplexador (a) e do Multiplexador (b).

Foram necessários alguns testes para verificar o desempenho do requantizador, de maneira a definir em que situações deveria ser efetuada a requantização e qual deveria ser a constante $\mathrm{k}$ que multiplicaria os elementos da matriz de quantização.

Primeiramente, foi variada a constante $\mathrm{k}$ e verificado o fator de compressão resultante para alguns quadros do vídeo de trabalho (2 quadros I, 4 quadros $\mathrm{P}$ e 9 quadros B) na seguinte seqüência, IBBPBBPBBPBBPIB. Os resultados, apresentados na figura 6.17 (a) e (b), demonstram que o desempenho na redução da taxa de bits do vídeo é bastante significativo para uma degradação suave da qualidade objetiva do vídeo (PSNR). Comparando-se o desempenho na compressão de quadros I, P e B, observa-se uma variação grande entre os fatores de compressão. Nota-se ainda que ocorre uma saturação no fator de compressão para os quadros I e P a partir de $k=40$ e para os quadros B a partir de $k=20$. Deve-se ter em mente, no entanto, que esses resultados foram obtidos para um número reduzido de slices dos três tipos de quadros e que, para um slice qualquer do vídeo recebido na transmissão, os resultados podem variar significativamente. 
Especificação dos módulos do framework para testes e avaliação do sincronismo

Fator de Compressão

(No. bytes original / No. bytes quantizados)

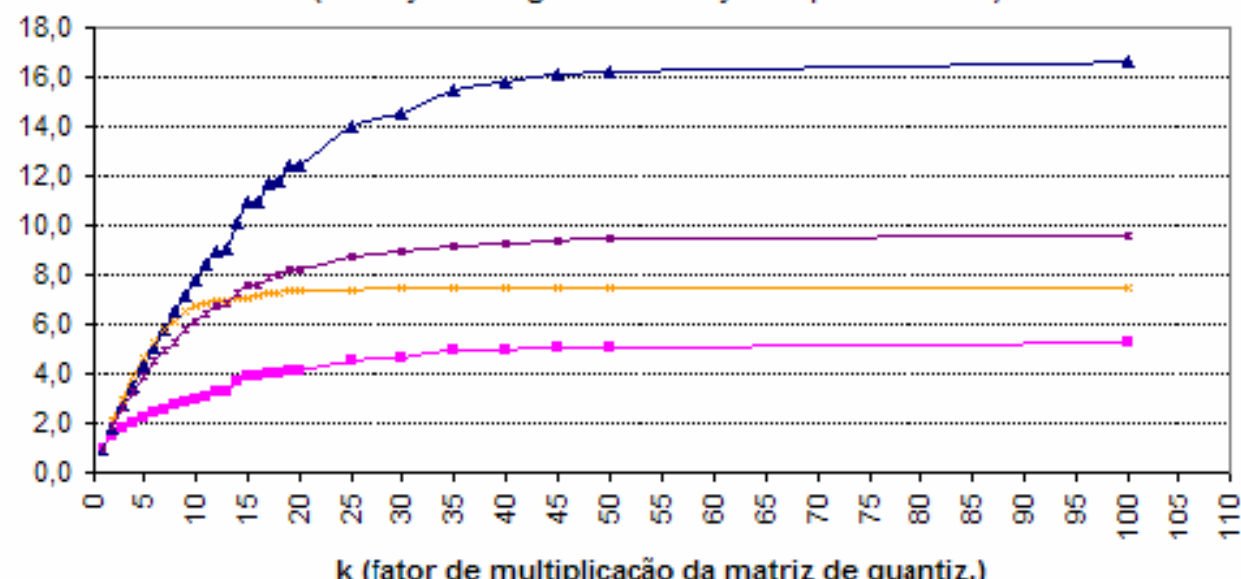

$\because-1 \quad \leftarrow \mathrm{P} \quad \longrightarrow$ B $\quad \rightarrow$ Global

(a)

PSNR versus $k$

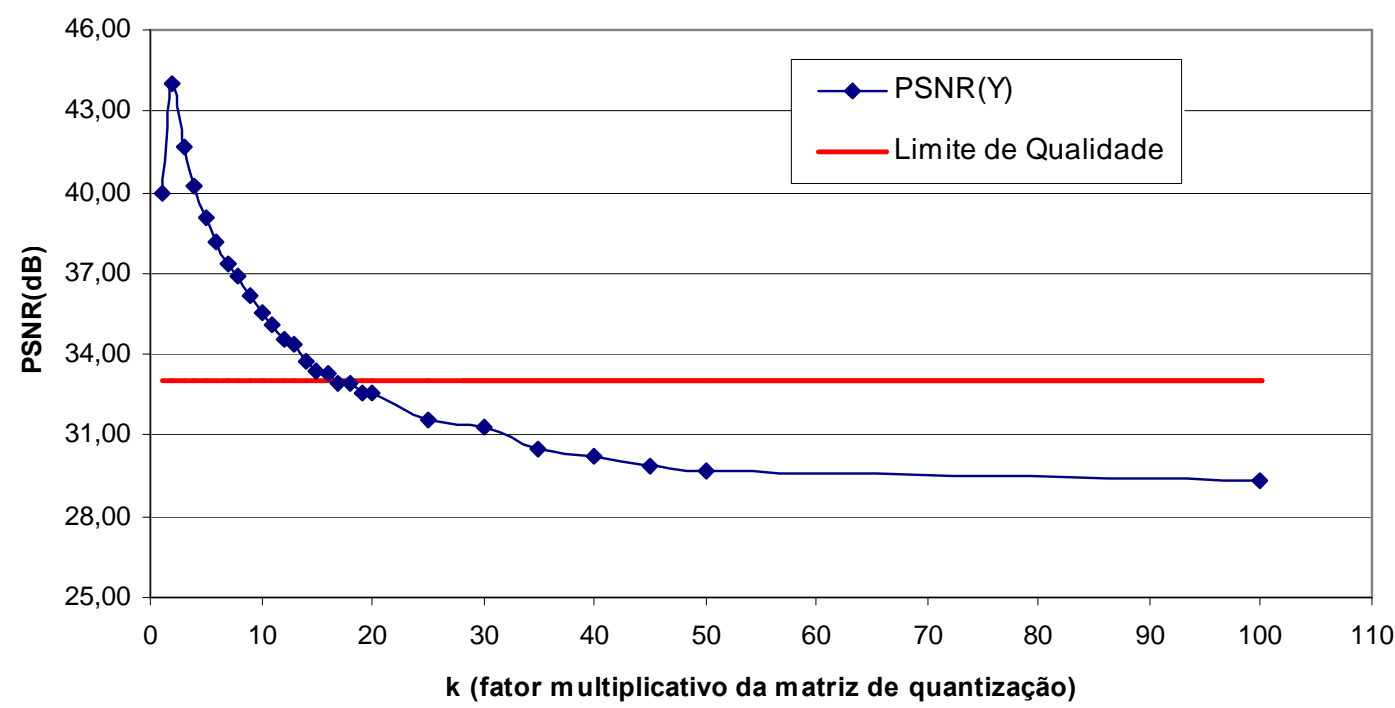

(b)

Figura 6.17 - Fator de compressão (a) e PSNR (b) em função da constante de multiplicação da matriz de quantização $(\mathrm{k})$. 
Especificação dos módulos do framework para testes e avaliação do sincronismo

O segundo teste teve como objetivo determinar o comportamento do atraso que pacotes TS sofrem durante a transmissão pela rede de distribuição. Esse teste foi fundamental para que fosse definido um limiar razoável para disparar a atuação do requantizador. Como os processos de demultiplexação, requantização e multiplexação são computacionalmente mais complexos e possuem tempo de processamento que não pode ser negligenciado, não é possível requantizar todos os pacotes TS que estejam atrasados sem comprometer a qualidade do vídeo exibido pelo módulo de recepção. Portanto, é fundamental definir um limiar para o atraso do pacote em relação ao modelo de temporização do MPEG2, definido no capítulo 4. Em outras palavras, é necessário medir quanto os pacotes encontram-se atrasados considerando como referência o instante que eles deveriam ter sido recebidos, de acordo com os requisitos do modelo de temporização. Na figura 6.18, apresenta-se um gráfico com as estatísticas da variação de atraso das amostras do PCR para o vídeo de trabalho, para uma variação de atraso na rede de distribuição de $5 \mathrm{~ms}$. Podem ser observados vários picos dessa métrica. Esses picos implicam em atrasos excessivos, que não poderão ser compensados no módulo de recepção, e, portanto, devem ser tratados pelo módulo de ressincronismo.

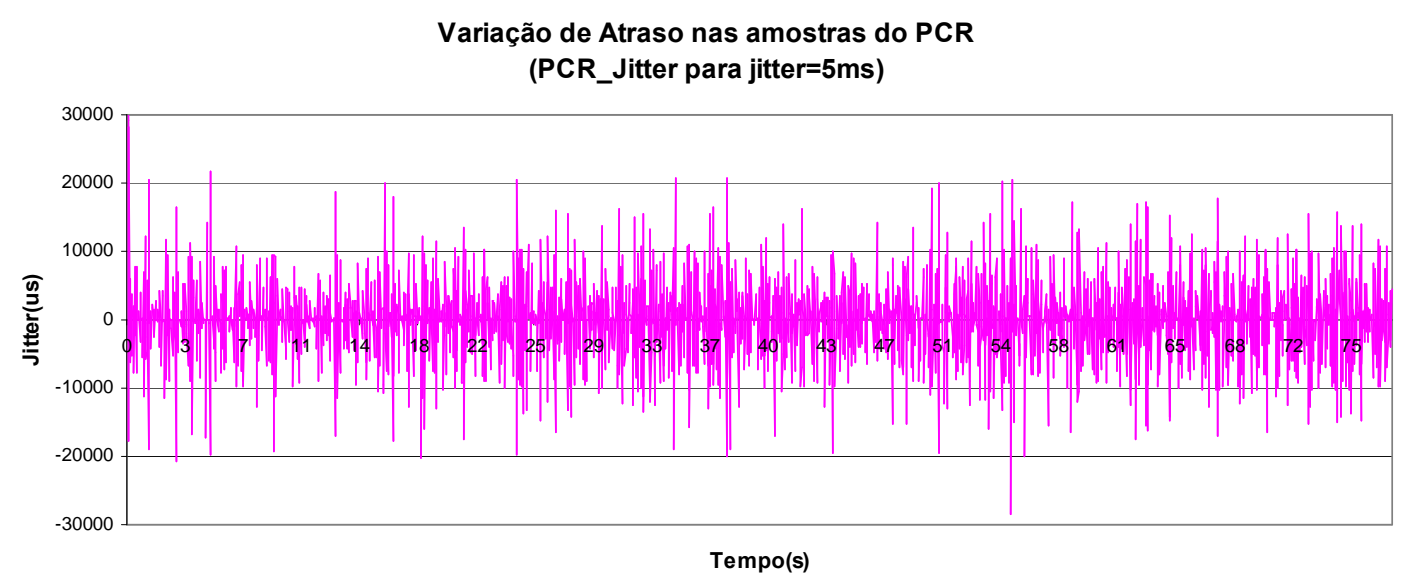

Figura 6.18 - Variação de Atraso das amostras do PCR de acordo com o Modelo de Temporização do MPEG2.

Para o método por requantização, a constante multiplicativa $k$ deve assumir um valor que garanta uma forte compressão do vídeo e o limiar de atraso, um valor 
Especificação dos módulos do framework para testes e avaliação do sincronismo

suficiente para evitar que todos os pacotes sejam requantizados, mas também que os picos de atraso sejam tratados. A partir dos testes descritos acima, a constante $k$ foi escolhida como o ponto onde o gráfico de qualidade objetiva de vídeo cruza o limite de qualidade excelente de $33 \mathrm{~dB}$, ou seja, foi escolhido $k=17$. Já o limiar de atraso escolhido foi de $10 \mathrm{~ms}$, tomando-se o gráfico da figura 6.18 como base e observando-se que grande parte dos picos de variação de atraso das amostras do PCR tem valores maiores que $10 \mathrm{~ms}$.

Uma vez especificados o valor de $\mathrm{k}$ e o limiar de atraso para efetuar a requantização, o último componente do método especificado nesta seção, a função de controle da requantização, pode ser descrito. Essa função aplica as condições especificadas no parágrafo anterior e é utilizada como indicador de quando efetuar a requantização. Caso o valor de retorno da função for igual a 1 , as atividades mostradas no diagrama da figura 6.15 são executadas, caso contrário, os pacotes TS são retransmitidos sem alteração. Na figura 6.19 é apresentado o pseudo-código dessa função, sendo possível identificar o valor do limiar de atraso, ou seja, $10 \mathrm{~ms}$.

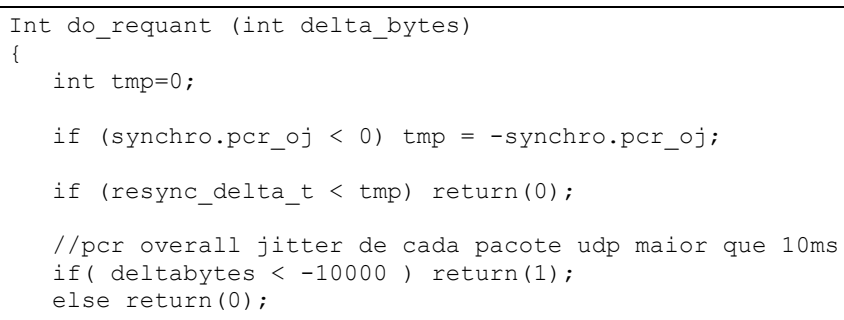

Figura 6.19 - Função de controle da requantização.

Finalmente, na figura 6.20 é mostrado o diagrama de blocos da implementação global do método por requantização dos slices do vídeo comprimido. São mostradas todas as atividades envolvidas, sendo o requantizador expandido em dois blocos: o de leitura dos cabeçalhos e o de requantização de slices. 


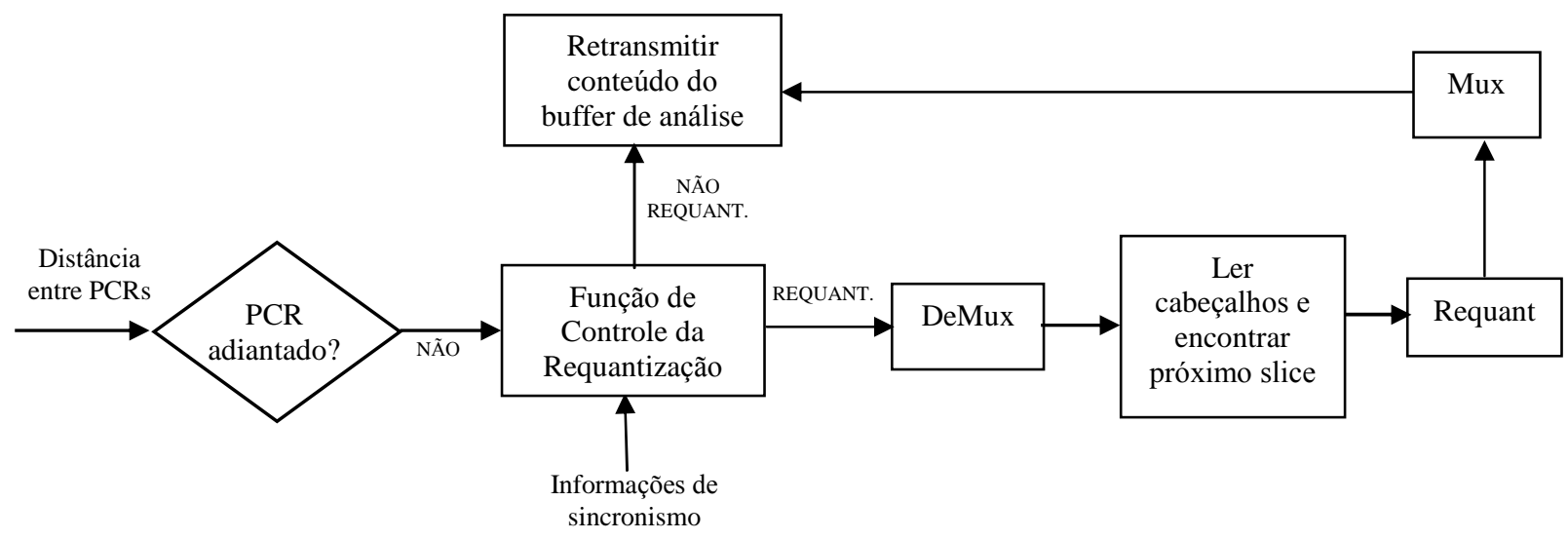

Figura 6.20 - Diagrama de Blocos do método por requantização dos slices do vídeo comprimido.

\subsection{Módulo de Recepção}

Este módulo é constituído por equipamentos localizados nas dependências do usuário (CPE, Customer Premisses Equipment), ou seja, antenas receptoras, redes internas às residências e caixas de conversão digital-analógica (Unidades Receptoras e Decodificadoras, URD). Esses equipamentos têm diversas funções, tais como: a recepção e demodulação do sinal digital; a demultiplexação dos sinais de vídeo, áudio e dados; a decodificação dos fluxos elementares (vídeo e áudio); a recuperação do relógio do emissor; a sincronização das mídias e a exibição ao usuário.

No framework proposto, esse módulo foi bastante simplificado e simula somente as funções principais para o usufruto da transmissão digital de televisão: a demultiplexação, a decodificação, sincronização das mídias, e sua apresentação ao usuário. Essas tarefas são implementadas por meio de um computador que executa um cliente de streaming de vídeo em redes IP, sendo que, a URD é um PC convencional com um software adequado.

O Software escolhido para efetuar as tarefas desejadas foi o VLC ${ }^{43}$ (VideoLAN Client), entretanto, ao contrário do módulo de transmissão, foi utilizada a versão mais completa disponível à época (versão 0.8.1) e que implementava uma série de funções para a exibição do vídeo e do áudio. A idéia foi simular o software

${ }^{43}$ VIDEOLAN. Disponível em : <http://www.videolan.org>. Acesso em: 30 jan. 2006. 
da URD com algum outro software que implementasse as funções essenciais para a recepção e exibição dos fluxos de mídia. Além disso, esse software deveria ser devidamente otimizado para a exibição síncrona das mídias e para a recuperação do sincronismo por meio das amostras do PCR. Na figura 6.21 são mostradas algumas telas da interface gráfica do VLC que apresentam uma cena do vídeo.

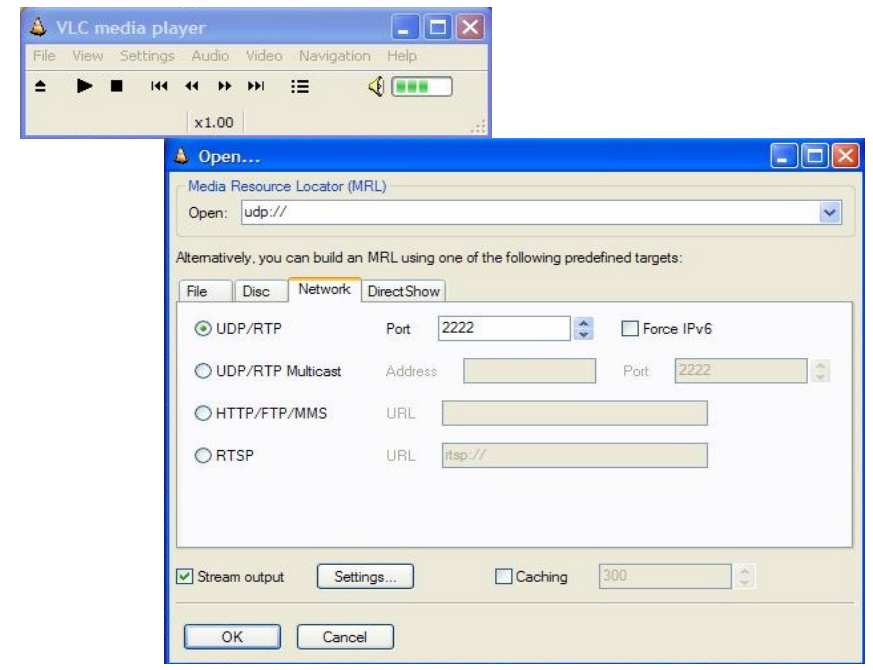

(a)

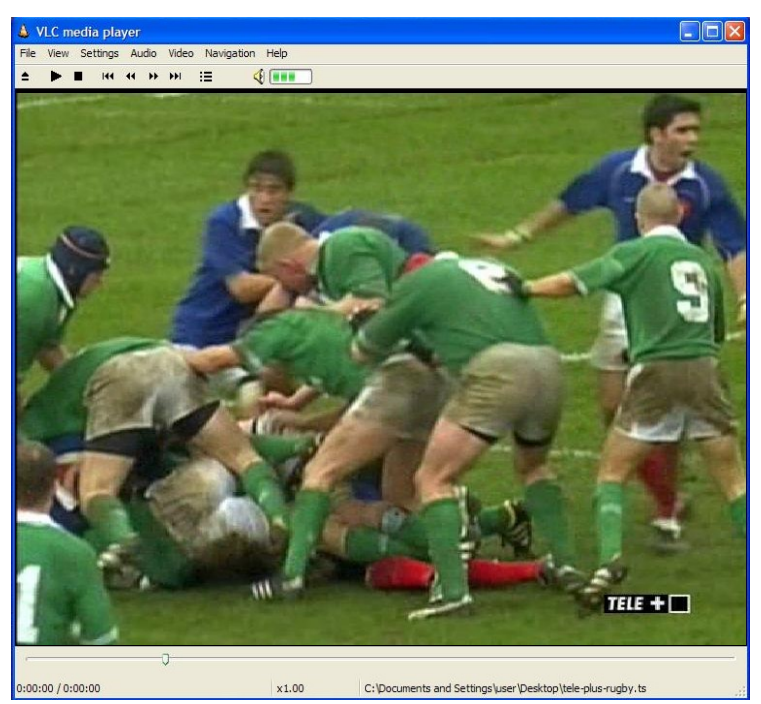

(b)

Figura 6.21 - Interface gráfica da área de configuração do VLC (a) e da área de exibição de vídeo do VLC (b). 
Especificação dos módulos do framework para testes e avaliação do sincronismo

\subsection{Módulo de Avaliação da Qualidade de Vídeo}

O módulo de Avaliação da Qualidade de Vídeo tem o objetivo de monitorar a qualidade objetiva do vídeo exibido pelo módulo de recepção se comparado com o vídeo original, de forma a medir as imperfeições ocasionadas pela transmissão do vídeo através de uma rede de distribuição baseada em pacotes.

A idéia principal desse módulo é fornecer informações sobre a qualidade do vídeo recebido para avaliar a influência dos parâmetros de QoS e a eficiência da ressincronização. Numa implementação comercial, as informações calculadas por esse módulo poderiam ser utilizadas, por exemplo, pelo módulo de ressincronização para efetuar uma sintonia fina dos algoritmos de ressincronização. Entretanto, no framework proposto, o escopo das funções desse módulo foi restringido para que sua implementação não se tornasse demasiadamente complexa, pois o objetivo final do módulo é fornecer informações para a avaliação dos impactos dos parâmetros de QoS no sincronismo do vídeo.

Com isso em mente, foram selecionados alguns programas ${ }^{44}$ utilizados para calcular determinada métrica de aferição de qualidade objetiva de vídeo e/ou distorção entre dois vídeos. Entre as métricas mais utilizadas está o PSNR (Peak Signal to Noise Ratio), o qual fornece informações suficientes para comparar os métodos de ressincronização propostos (requantização e descarte de pacotes dos frames B) e também para avaliar a influência dos parâmetros de QoS. Além disso, o PSNR é uma métrica simples de ser calculada e com algoritmos amplamente disponíveis.

O PSNR se baseia numa medida de erro médio quadrático (MSE, Mean Square Error) dos pixels de cada quadro do vídeo recebido em relação ao vídeo original. Conforme apresentado por Singh (SINGH, 2005), para uma seqüência de K quadros de um vídeo cada um com $\mathrm{N}^{*} \mathrm{M}$ pixels e $\mathrm{m}$ bits por pixel, a MSE seria calculada por meio da equação 6.1 abaixo.

\footnotetext{
${ }^{44}$ VQM. Disponível em : <http://www.its.bldrdoc.gov/n3/video/vqmsoftware.htm>. Acesso em: 30 jan. 2006. VACUM. Disponível em : <http://sourceforge.net/projects/vacum/>. Acesso em: 30 jan. 2006.
} 


$$
\mathrm{MSE}=\left[\mathrm{N}^{*} \mathrm{M}^{*} \mathrm{~K}\right]^{-1} * \sum_{1 . . \mathrm{K}} \sum_{1 . . \mathrm{N}} \sum_{1 . . \mathrm{M}}\left[\mathrm{x}(\mathrm{i}, \mathrm{j}, \mathrm{k})-\mathrm{x}^{\prime}(\mathrm{i}, \mathrm{j}, \mathrm{k})\right]^{2}
$$

Onde x(i, j, k) e x'(i,j, k) são valores dos pixels de luminância ou crominância na posição $(\mathrm{i}, \mathrm{j})$ do k-ésimo quadro das seqüências de vídeo original e distorcida, respectivamente. Outra medida relevante é o RMSE (Root MSE), que é calculado conforme a equação 6.2 abaixo:

$$
\mathrm{RMSE}=[\mathrm{MSE}]^{1 / 2}
$$

O PSNR, por sua vez, é calculado por meio da equação 6.3 a seguir:

$$
\mathrm{PSNR}=10 \log \left[\mathrm{m}^{2} /(\mathrm{RMSE})^{2}\right], \text { onde } \mathrm{m}=255 .
$$

O MSE e o RMSE medem a diferença entre as seqüências original e distorcida. Já o PSNR mede a fidelidade das seqüências, ou seja, quão similares são a seqüência distorcida e a original. Comparada com outras medidas, o PSNR é fácil de calcular e é bastante compreendido no meio acadêmico. Entretanto, a correlação com medidas subjetivas de qualidade de vídeo é pobre (SINGH, 2005). Para efetuar testes, deve-se observar um único quadro ou calcular uma média de alguns quadros, dependendo dos requisitos. Nesta dissertação, foi considerada para a avaliação de qualidade a média dos PSNR de todos os quadros do vídeo recebido, em relação ao original.

O programa escolhido para calcular o PSNR foi o VACUM 0.1 (Vídeo Analysis and Comparison Utilities and More $)^{45}$, desenvolvido pelo Massachusetts Institute of Technology (MIT), para a plataforma Unix. O VACUM é um programa em linha de comando, que possui as entradas apresentadas na figura 6.23(a). Algumas informações simples devem ser especificadas: a resolução dos quadros, o número de quadros por segundo e os arquivos dos vídeos original e recebido. Nota-se que o cálculo do PSNR é feito posteriormente à recepção e exibição dos vídeos. A escolha de um programa que efetua a avaliação "offline" foi uma decisão de projeto, pois foi privilegiada a avaliação dos parâmetros de QoS da rede, em detrimento à

${ }^{45}$ VACUM. Disponível em : <http://sourceforge.net/projects/vacum/>. Acesso em: 30 jan. $2006 .$. 
Especificação dos módulos do framework para testes e avaliação do sincronismo

realimentação das informações de qualidade do vídeo. Os algoritmos implementados no framework são autônomos e não recebem informações desse módulo.

Além disso, algumas dificuldades adicionais foram encontradas. O VACUM somente calcula o PSNR com arquivos no formato YUV, ou seja, sem compressão; e o VLC recebe o Fluxo de Transporte e não o vídeo demultiplexado. Para solucionar esses dois problemas foi necessário utilizar um programa para demultiplexar os pacotes de vídeo do fluxo de transporte, o XMuxer $2.3^{46}$; e outro para converter os vídeos MPEG2 demultiplexados no formato YUV, o MPlayer 1.0pre7-3.4.2 ${ }^{47}$. A Figura 6.22 (b) e 6.22 (c) mostram, respectivamente, a interface do XMuxer e os parâmetros de linha de comando do MPlayer.

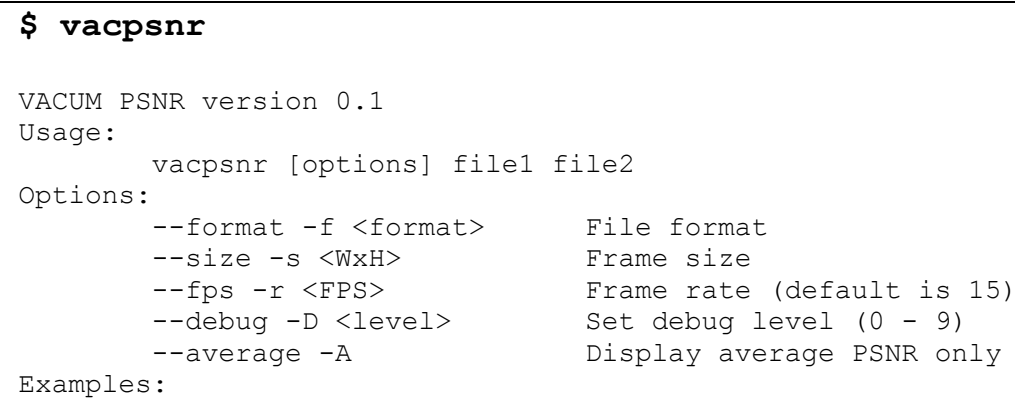

(a)

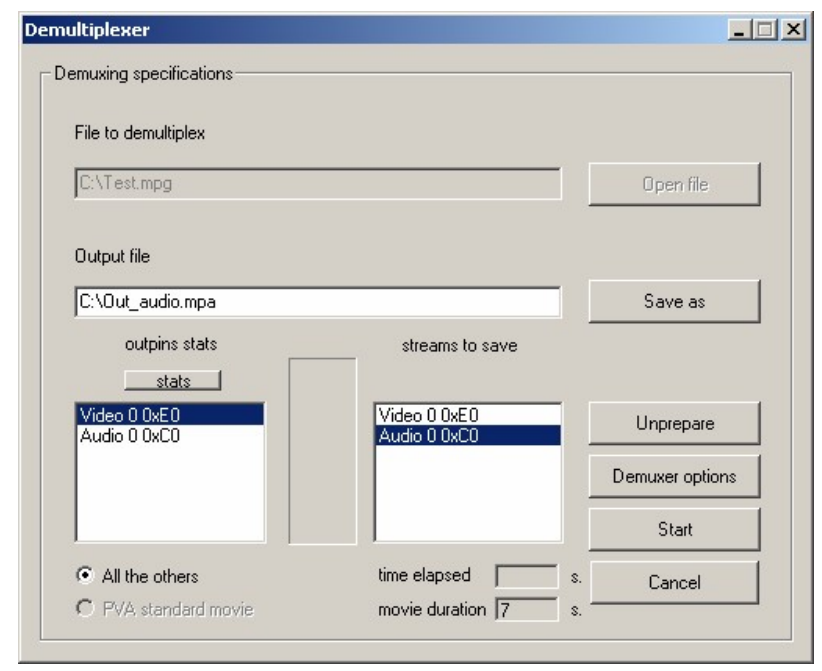

(b)

\footnotetext{
${ }^{46}$ XMuxer. Disponível em : $<$ http://moonlight.co.il/cons_xmuxer.php>. Acesso em: 30 jan. $2006 .$.

${ }^{47}$ MPlayer. Disponível em : <http://www.mplayerhq.hu/homepage/design7/new.html $>$. Acesso em: 30 jan. 2006.
} 


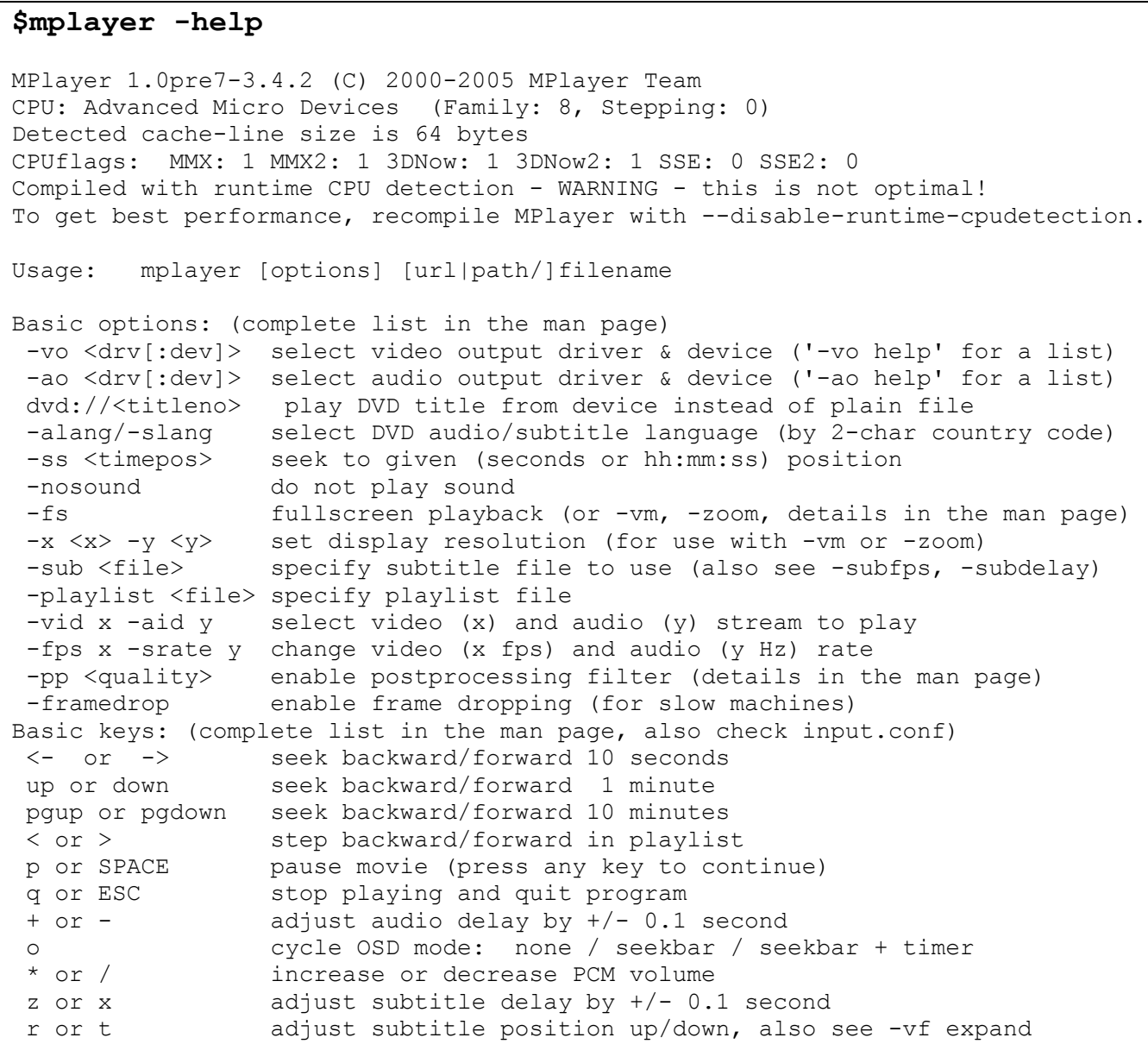

(c)

Figura 6.22 - Interfaces dos programas utilizados no módulo de Avaliação da Qualidade do Vídeo, (a) VACUM, (b) XMuxer e (c) Mplayer. 
Especificação dos módulos do framework para testes e avaliação do sincronismo

Com informações de qualidade objetiva do vídeo, foi possível efetuar testes em diversas condições da rede e avaliar como a qualidade do vídeo é afetada. Conforme explicitado nas seções anteriores, a variação dos parâmetros de QoS da rede possibilita o estudo da influência deles sobre a qualidade objetiva do vídeo recebido pelo módulo de recepção.

\subsection{Módulo de Monitoração das Características das Amostras do PCR}

O módulo de monitoração das características das amostras do PCR, denominado, para fins desta dissertação, PCRPROBE, tem como objetivo fundamental registrar a atividade das amostras do PCR no Fluxo de Transporte, registrando diversas métricas dessas amostras.

No capítulo 4, foram descritas as principais métricas medidas pelo PCRPROBE, são elas:

- PCR $(\mu \mathrm{s})$ : valor da amostra do PCR, em microssegundos, obtido por meio do número de transições do relógio indicado pelo OPCR do campo de adaptação dos pacotes que contenham amostras do PCR;

- Delta_bytes: número de bytes recebidos entre duas amostras consecutivas do PCR;

- Transport_rate: taxa de bits do fluxo de transporte. Essa taxa é constante entre amostras consecutivas do PCR. Entretanto, a cada nova amostra do PCR, seu valor é atualizado. É obtido pela seguinte expressão:

Transport_rate $=8 *$ Delta_bytes / Delta_tpcr;

- Delta_tpcr: diferença, em microssegundos, entre a amostra atual do PCR e a imediatamente anterior;

- Delta_t: diferença, em microssegundos, entre o instante de chegada da amostra atual do PCR e o instante de chegada da amostra imediatamente anterior;

- Delta_tb: diferença temporal entre a amostra do PCR atual e a amostra imediatamente anterior calculada a partir do número de bytes entre as duas amostras. Ou seja, a diferença é calculada pela seguinte expressão:

Delta_tb $[\mathrm{i}]=8 *$ Delta_bytes $[\mathrm{i}, \mathrm{i}-1] /$ Transport_rate[i-1]; 
- PCR_Jitter: diferença entre delta_tpcr e delta_t, ou seja, medida da diferença temporal entre valores registrados nas amostras do PCR e a efetiva chegada das amostras do PCR. Mede a variação de atraso real das amostras do PCR.

Para o framework proposto, foi desenvolvido um software com intuito de registrar tais métricas. Esse software intercepta os pacotes TS do fluxo de transporte, identifica quais deles possuem amostras do PCR, efetua os cálculos necessários para obter as métricas descritas acima e armazena tais informações num arquivo de saída.

A figura 6.7 apresenta a função que efetua os cálculos das métricas, de forma que possa ser verificada a metodologia utilizada. Para o cálculo de Delta_t é necessário registrar o instante de chegada de cada pacote TS e efetuar a diferença entre os instantes de chegada das amostras. Isso é feito na função sync_main, apresentada no código fonte do módulo de ressincronismo (anexo I).

Nos próximos capítulos são especificados os cenários de teste utilizados para avaliar o framework proposto. São também apresentados os resultados obtidos e discutidas as conclusões, além de serem avaliados os resultados da atuação do NISTNet em parâmetros como a variação de atraso. 


\section{CENÁRIOS DE TESTE E RESULTADOS EXPERIMENTAIS}

Neste capítulo são especificados os cenários de teste para a validação do framework proposto, avaliando o desempenho dos métodos de ressincronização e estabelecendo os efeitos dos parâmetros da rede de distribuição na qualidade objetiva do vídeo recebido.

Os testes avaliaram a atuação dos métodos de ressincronização para minimizar efeitos da variação de atraso nas amostras do PCR no Fluxo de Transporte, ou seja, investigaram como o módulo de ressincronismo atuava no sincronismo das amostras do PCR e, conseqüentemente, no sincronismo para a recepção do fluxo de pacotes TS

Além disso, os testes quantificaram a qualidade do vídeo recebido pelo módulo de recepção em diversas situações: introduzindo perturbações por meio do módulo de controle da rede, inserindo ou não o módulo de ressincronismo e alternando cada um dos métodos de ressincronismo especificados.

Para a implementação dos testes foram definidos cenários que tinham como objetivo avaliar a influência dos dois módulos ativos do framework: os módulos de controle da rede e de ressincronismo. Foram então avaliados os seguintes métodos de ressincronização: inserção de pacotes nulos, descarte de pacotes de quadros B e requantização dos slices do vídeo comprimido.

Além da especificação dos cenários de teste, neste capítulo são apresentados e discutidos os resultados experimentais. A partir dos resultados obtidos, os métodos são comparados em seu desempenho para atuar na ressincronização dos pacotes TS e na manutenção da qualidade objetiva do vídeo recebido.

\subsection{Cenários de Teste}

De acordo com os objetivos apresentados nos capítulos 5 e 6, foram especificados quatro cenários para testar o framework proposto:

- Avaliação da influência dos parâmetros de QoS na qualidade objetiva do vídeo recebido; 
- Avaliação isolada do método de inserção de pacotes nulos;

- Avaliação do ressincronismo implementado por meio dos métodos de inserção de pacotes nulos e de descarte de pacotes dos quadros B; e

- Avaliação do ressincronismo implementado por meio dos métodos de inserção de pacotes nulos e de requantização de slices do vídeo comprimido.

Cada um dos cenários possui um propósito específico e foi executado segundo determinada lógica para que fossem avaliadas algumas condições de operação do framework proposto, antes de avaliar os métodos de ressincronização. Por exemplo, o primeiro cenário tem como propósito mensurar quanto e como os parâmetros de QoS influenciam a qualidade objetiva do vídeo recebido, ou seja, como o módulo de controle da rede atua. Dessa maneira cada um dos cenários foi executado para avaliar algum aspecto do framework. O resumo desses objetivos e a indicação da ordem de execução dos testes podem ser verificados na tabela 7.1.

A idéia central que norteou os testes foi a de analisar primeiramente os impactos do módulo de controle de rede, pois esse módulo influenciava todos os outros cenários. Após a análise do módulo de controle da rede, avaliou-se o método de inserção de pacotes nulos, pois esse método seria utilizado nos dois últimos cenários. Em seguida, foi avaliado o módulo de ressincronismo como um todo, utilizando os dois métodos propostos, de descarte de pacotes de quadros B e de requantização de slices, tendo sido especificados, para esse fim, dois outros cenários. 
Tabela 7.1 - Principais objetivos e aspectos analisados para cada um dos cenários de teste.

\begin{tabular}{|c|c|c|c|}
\hline Cenário de Teste & $\begin{array}{l}\text { Ordem de } \\
\text { Execução }\end{array}$ & Objetivo Principal & $\begin{array}{c}\text { Aspectos } \\
\text { Analisados }\end{array}$ \\
\hline $\begin{array}{l}\text { A influência dos parâmetros de QoS } \\
\text { na qualidade objetiva do vídeo } \\
\text { recebido. }\end{array}$ & $1^{\mathrm{o}}$ & $\begin{array}{l}\text { Mensurar como e } \\
\text { quanto os parâmetros de } \\
\text { QoS influenciam o } \\
\text { sincronismo dos PCRs e } \\
\text { a qualidade objetiva do } \\
\text { vídeo recebido. }\end{array}$ & $\begin{array}{l}\text { Atraso, variação de } \\
\text { atraso, perda de } \\
\text { pacotes e duplicação } \\
\text { de pacotes. }\end{array}$ \\
\hline $\begin{array}{l}\text { Avaliação isolada do método de } \\
\text { inserção de pacotes nulos. }\end{array}$ & $2^{\circ}$ & $\begin{array}{l}\text { Mensurar como e } \\
\text { quanto o método de } \\
\text { inserção de pacotes } \\
\text { nulos, isoladamente, } \\
\text { auxilia na manutenção } \\
\text { do sincronismo dos } \\
\text { PCRs e da qualidade do } \\
\text { vídeo recebido. }\end{array}$ & $\begin{array}{l}\text { Inserção de pacotes } \\
\text { nulos para a } \\
\text { manutenção da } \\
\text { distância entre PCRs } \\
\text { quando a última } \\
\text { amostra estiver } \\
\text { adiantada. }\end{array}$ \\
\hline $\begin{array}{l}\text { Avaliação do ressincronismo } \\
\text { implementado por meio dos } \\
\text { métodos de inserção de pacotes } \\
\text { nulos e de descarte de pacotes dos } \\
\text { quadros B. }\end{array}$ & $3^{\circ}$ & $\begin{array}{l}\text { Mensurar como e } \\
\text { quanto o módulo de } \\
\text { ressincronismo auxilia } \\
\text { na manutenção do } \\
\text { sincronismo dos PCRs e } \\
\text { da qualidade do vídeo } \\
\text { recebido. }\end{array}$ & $\begin{array}{l}\text { Manutenção do } \\
\text { sincronismo quando } \\
\text { o último PCR estiver } \\
\text { adiantado ou } \\
\text { atrasado. }\end{array}$ \\
\hline $\begin{array}{l}\text { Avaliação do ressincronismo } \\
\text { implementado por meio dos } \\
\text { métodos de inserção de pacotes } \\
\text { nulos e de requantização de slices } \\
\text { do vídeo comprimido. }\end{array}$ & $4^{\circ}$ & $\begin{array}{l}\text { Mensurar como e } \\
\text { quanto o módulo de } \\
\text { ressincronismo auxilia } \\
\text { na manutenção do } \\
\text { sincronismo dos PCRs e } \\
\text { qualidade do vídeo } \\
\text { recebido. }\end{array}$ & $\begin{array}{l}\text { Manutenção do } \\
\text { sincronismo quando } \\
\text { o último PCR estiver } \\
\text { adiantado ou } \\
\text { atrasado. }\end{array}$ \\
\hline
\end{tabular}

\subsubsection{Cenário 1: Influência dos parâmetros de QoS na qualidade objetiva do vídeo recebido}

Nesse cenário o interesse principal foi o módulo de controle da rede, por isso

o módulo de ressincronismo do framework proposto foi excluído. $\mathrm{O}$ diagrama dos blocos utilizados no teste é apresentado na figura 7.1. 


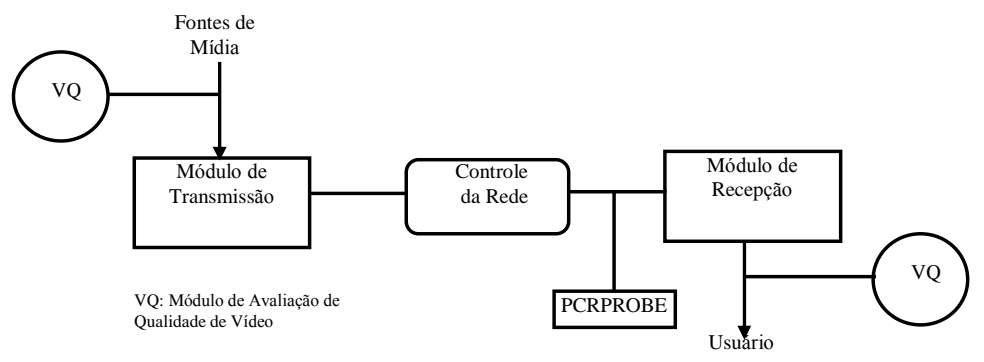

Figura 7.1 - Diagrama de Blocos do Cenário 1.

O teste consistiu em transmitir pacotes TS do vídeo por meio do módulo de transmissão e recebê-los no módulo de recepção, armazenando-os em um arquivo de saída para registro e posterior análise. No entanto, entre os módulos de transmissão e recepção havia o módulo de controle da rede que foi utilizado para variar as características da rede e o módulo de monitoração das características das amostras do PCR, denominado PCRPROBE, que tem o objetivo de registrar o comportamento das amostras do PCR (distância em bytes entre amostras, tempo de chegada de cada amostra, variação de atraso nos PCRs, etc).

O procedimento de teste iniciou-se com o registro do comportamento das amostras do PCR pelo PCRPROBE, especialmente a variação de atraso das amostras do PCR, para duas situações específicas: sem a adição de variação de atraso adicional na rede, e fixando um valor de variação de atraso para a rede no módulo de controle da rede. As duas situações serviram para estabelecer o efeito da variação de atraso na rede para as amostras do PCR partindo-se da condição inicial sem variação de atraso.

Em seguida, os parâmetros de QoS foram variados até que a qualidade subjetiva do vídeo (análise visual do vídeo recebido) fosse ruim e não fosse mais possível assistir ao vídeo recebido. Para cada um dos valores associados a um determinado parâmetro de QoS, os pacotes TS foram recebidos, armazenados em um arquivo e por meio do módulo de avaliação da qualidade do vídeo foi obtido o valor da métrica de qualidade objetiva do vídeo.

Os seguintes parâmetros foram variados por meio do módulo de controle da rede: atraso, variação de atraso, perda de pacotes e duplicação de pacotes. O atraso e a variação de atraso foram os dois principais aspectos examinados nesse cenário de 
testes, pois o módulo de ressincronismo atua justamente para atenuar os efeitos de atrasos e variações de atraso nos pacotes TS. Entretanto, a perda de pacotes e a duplicação de pacotes são fenômenos comuns em redes de pacotes e, por isso, estão incluídos nesse cenário. Além disso, segundo Claypool e Bouazizi (CLAYPOOL; TANNER, 1999; BOUAZIZI, 2004), os efeitos da perda de pacotes e da variação de atraso são similares. Portanto, com o objetivo de comprovar essa tese decidiu-se por examinar também a perda de pacotes nesse cenário.

\subsubsection{Cenário 2: Avaliação isolada do método de inserção de pacotes nulos}

O segundo cenário teve como objetivo avaliar o módulo de ressincronismo, que atuava de forma restrita. Essa atuação se deve ao fato desse cenário utilizar apenas a inserção de pacotes nulos para ressincronizar as amostras do PCR. Na figura 7.2 é apresentado o diagrama de blocos desse cenário, onde nota-se que o módulo de ressincronismo é composto somente pelos elementos que implementam a inserção de pacotes nulos.

Como no cenário anterior, o módulo de transmissão enviava os pacotes TS para o módulo de recepção passando pelo módulo de controle da rede. Nesse cenário, porém, o módulo de ressincronismo interceptava o fluxo de pacotes, fazendo algumas análises e retransmitindo-o para o módulo de recepção. De maneira similar ao cenário 1, o módulo de recepção recebia e armazenava os pacotes TS em um arquivo de saída para posterior análise e o PCRPROBE registrava o comportamento das amostras do PCR. Além disso, nesse cenário, o módulo de controle da rede atuava modificando a variação de atraso na rede de distribuição.

Duas medições foram efetuadas: a medição da variação de atraso das amostras do PCR, utilizando o PCRPROBE com um valor fixo de variação de atraso na rede; e, a medição de uma métrica de qualidade objetiva, por meio do módulo de avaliação de qualidade, incrementando o valor da variação de atraso na rede. 


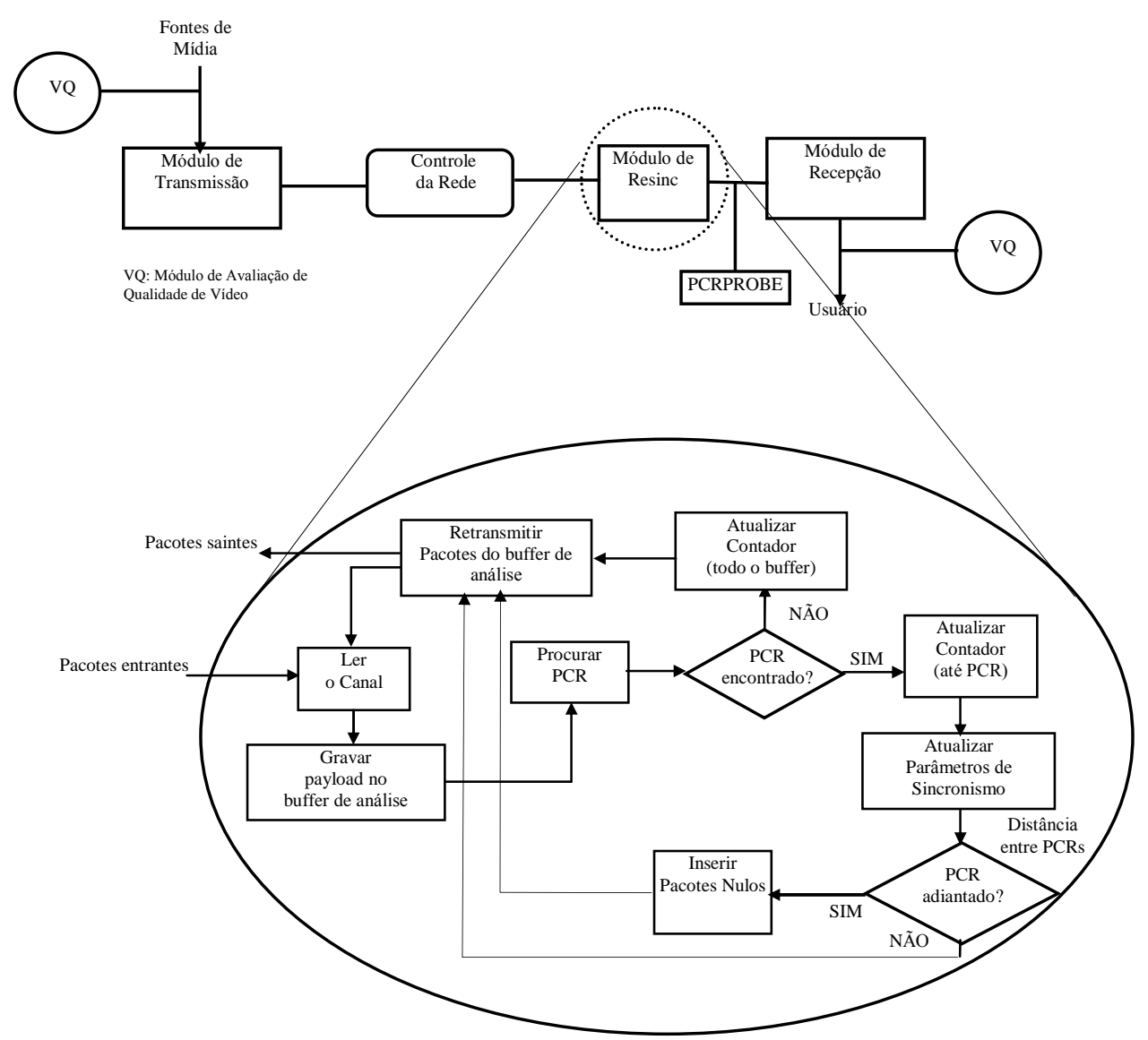

Figura 7.2 - Diagrama de Blocos do Cenário 2.

\subsubsection{Cenário 3: Avaliação do módulo de ressincronismo operando na inserção de pacotes nulos e no descarte de pacotes dos quadros $B$}

O cenário 3 teve o objetivo de avaliar o módulo de ressincronismo operando com os métodos de inserção de pacotes nulos e de descarte de pacotes dos quadros B. $\mathrm{O}$ procedimento de teste foi idêntico ao do cenário 2 , ou seja, o módulo de transmissão enviava os pacotes TS ao módulo de recepção, passando pelos módulos de controle da rede e de ressincronismo, registrando, por meio do PCRPROBE, o comportamento das amostras do PCR. Adicionalmente, ao módulo de ressincronismo foram acrescentadas funções para executar o descarte de pacotes dos quadros B, quando necessário.

Os resultados foram obtidos também de maneira similar ao cenário anterior. O módulo de recepção recebia e armazenava os pacotes TS em um arquivo de saída, 
utilizado para auferir as métricas de qualidade objetiva por meio do módulo de avaliação de qualidade, enquanto o PCRPROBE registrava a variação de atraso das amostras do PCR. Na figura 7.3 é apresentado o diagrama de blocos para esse cenário de testes. Nesse diagrama, pode ser verificado que, além das funções do cenário 2, foram acrescidos dois blocos, "Identificar o Tipo de Quadro" e "Descartar Pacotes". O primeiro, para determinar a que tipo de quadro os pacotes TS pertenciam; e o segundo, para descartar os quadros quando identificado que os pacotes pertenciam a um quadro $B$.

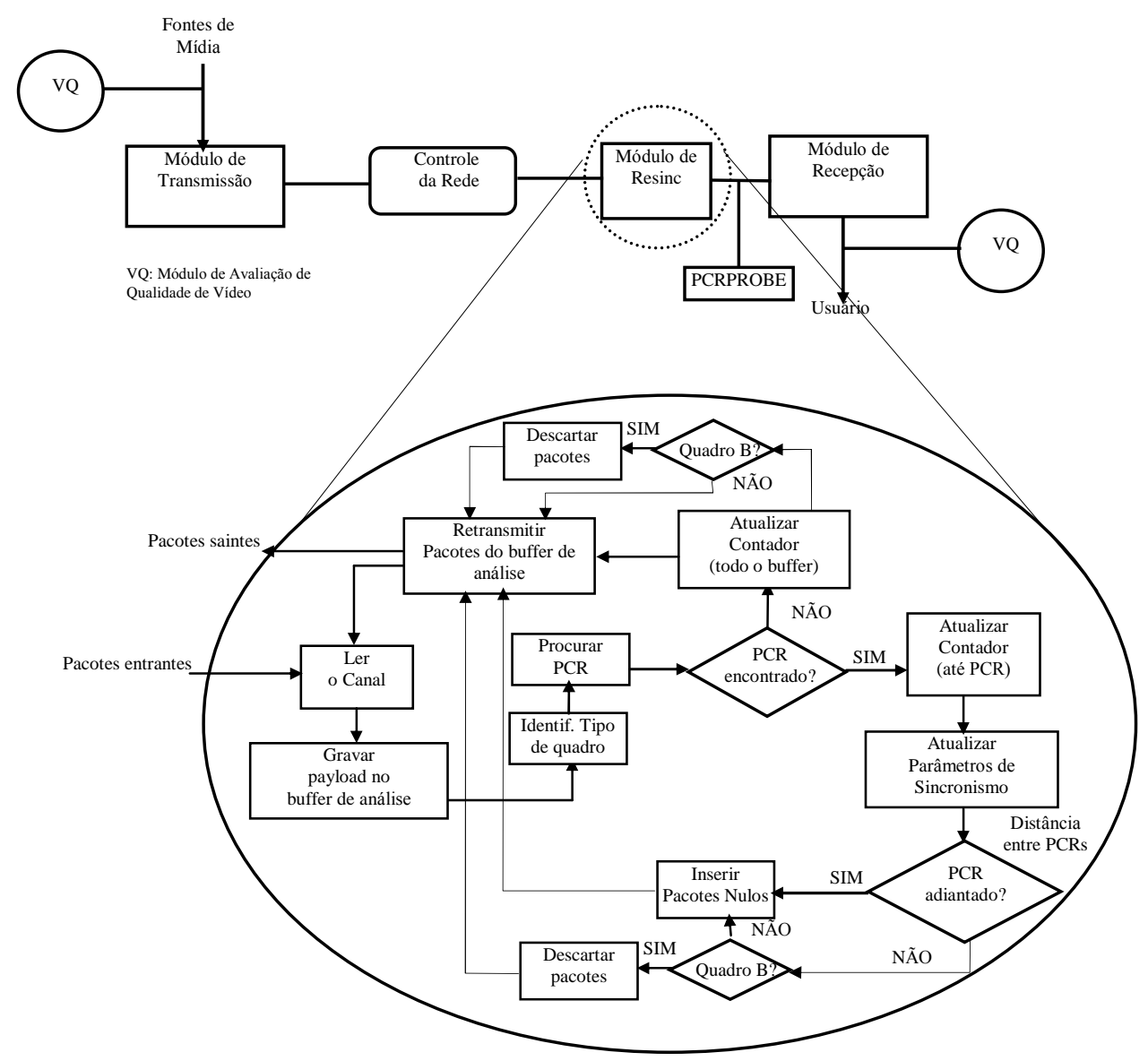

Figura 7.3 - Diagrama de Blocos do Cenário 3.

\subsubsection{Cenário 4: Avaliação do ressincronismo operando na inserção de pacotes nulos e na requantização de slices do vídeo}

Neste cenário, o procedimento também foi similar aos dos cenários 2 e 3, sendo bastante semelhante ao descrito na seção 7.1.3. Esses procedimentos, 
entretanto, têm como objetivo avaliar o módulo de ressincronismo operando no modo de inserção de pacotes e de requantização.

É importante considerar, todavia, a existência de certas particularidades não presentes nos cenários anteriores. Como pode ser observado na figura 7.4, que apresenta o diagrama de blocos desse cenário, alguns dos blocos são distintos daqueles introduzidos nas seções 7.1.2 e 7.1.3. Ao invés dos blocos de identificação do tipo de quadro e de descarte de blocos, são introduzidos quatro outros blocos: "controle da requantização", "multiplexação", "requantização" e "demultiplexação". Os resultados também foram obtidos por meio dos arquivos do vídeo recebido, posteriormente analisados pelo módulo de avaliação da qualidade e por meio do PCRPROBE.

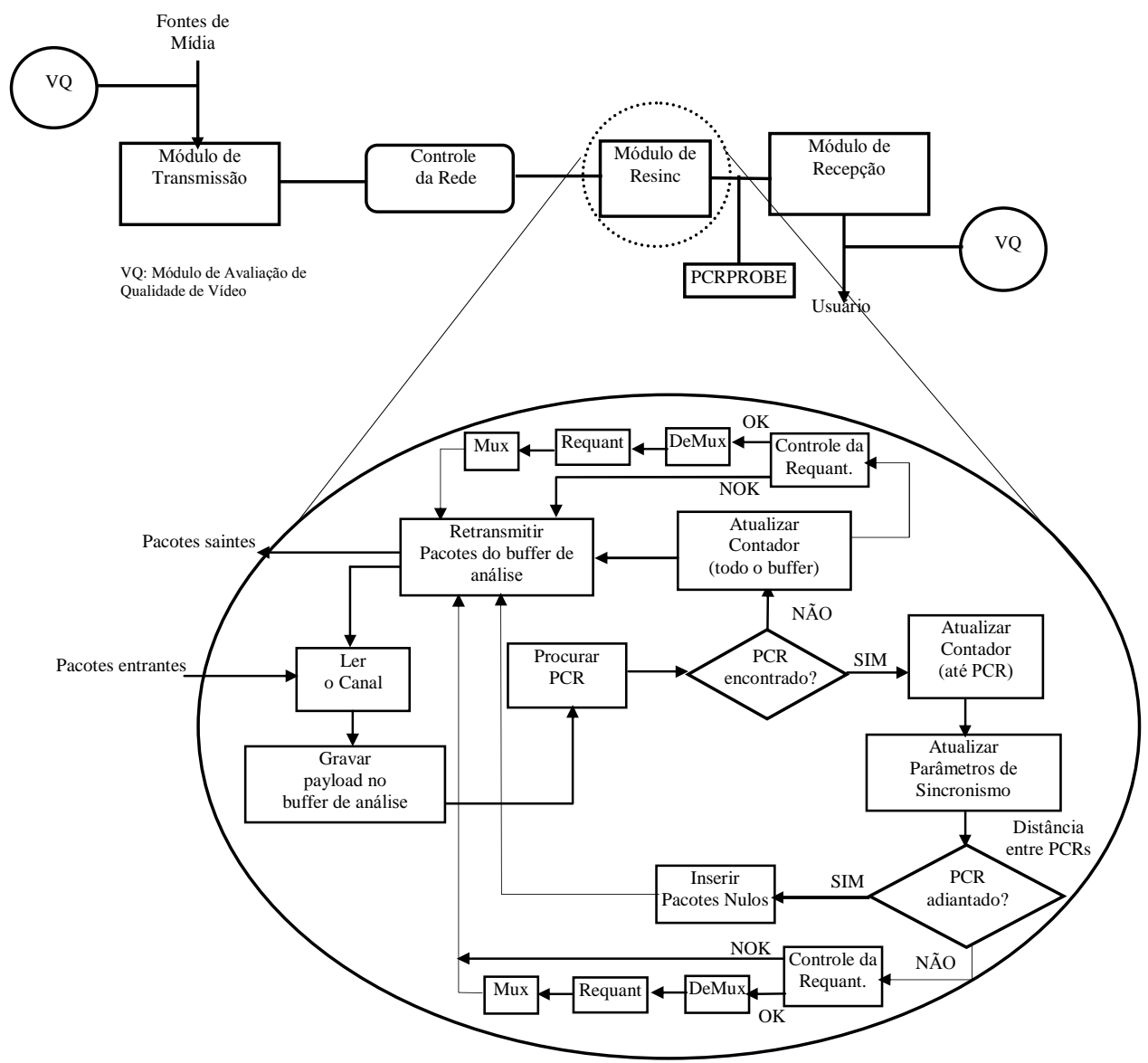

Figura 7.4 - Diagrama de Blocos do Cenário 4. 


\subsection{Resultados Experimentais}

Definidos os cenários dos testes, foram efetuadas medições para cada um deles. Nesta seção serão discutidos os resultados alcançados a fim de responder as questões propostas no capítulo 5, seção 5.3, que dizem respeito a como os parâmetros de QoS influenciam a qualidade objetiva do vídeo e como os métodos de ressincronização auxiliam na manutenção do sincronismo do fluxo de transporte.

Conforme descrito na seção 7.1, foram especificados quatro cenários e para cada um deles serão apresentados os resultados mais relevantes em termos do sincronismo e da qualidade objetiva do vídeo recebido.

Para facilitar o entendimento desses resultados, é essencial definir alguns parâmetros do vídeo e também descrever a metodologia utilizada. Essa reflexão é apresentada na seção 7.2.1.

\subsubsection{Aspectos do vídeo e da metodologia de testes}

O vídeo utilizado nos quatro cenários descritos na seção 7.1 é um trecho de um programa de esportes da emissora italiana TelePiu, em que são apresentadas cenas de um jogo de rugby e uma entrevista com um dos jogadores. O jogo apresenta movimento intenso e a entrevista, por outro lado, possui cenas bastante estáticas. A escolha desse vídeo se deu pela alternância de momentos com alta e baixa atividade do vídeo, ou seja, cenas com altas e baixas velocidades de mudança dos quadros.

A compressão utilizada no vídeo foi o MPEG2 na resolução SDTV (Standard Definition, Main Profile at Main Level, MP@ML), ou seja, o vídeo apresenta 1950 quadros de 544 pixels x 576 linhas, relação de aspecto 4:3 e exibição feita a 25 quadros por segundo em modo progressivo. O vídeo apresenta GOPs (Groups of Picture) de 12 quadros (IBBPBBPBBPBB), sendo que a distância entre um quadro âncora (I ou P) e o próximo quadro âncora é de 3 quadros. Em outras palavras, N=12 e M=3 (N, sendo o intervalo de um GOP e M, o intervalo de predição) para o vídeo utilizado. Para indicar como o nível de atividade do vídeo varia no decorrer dos quadros é apresentada a figura 7.5. 


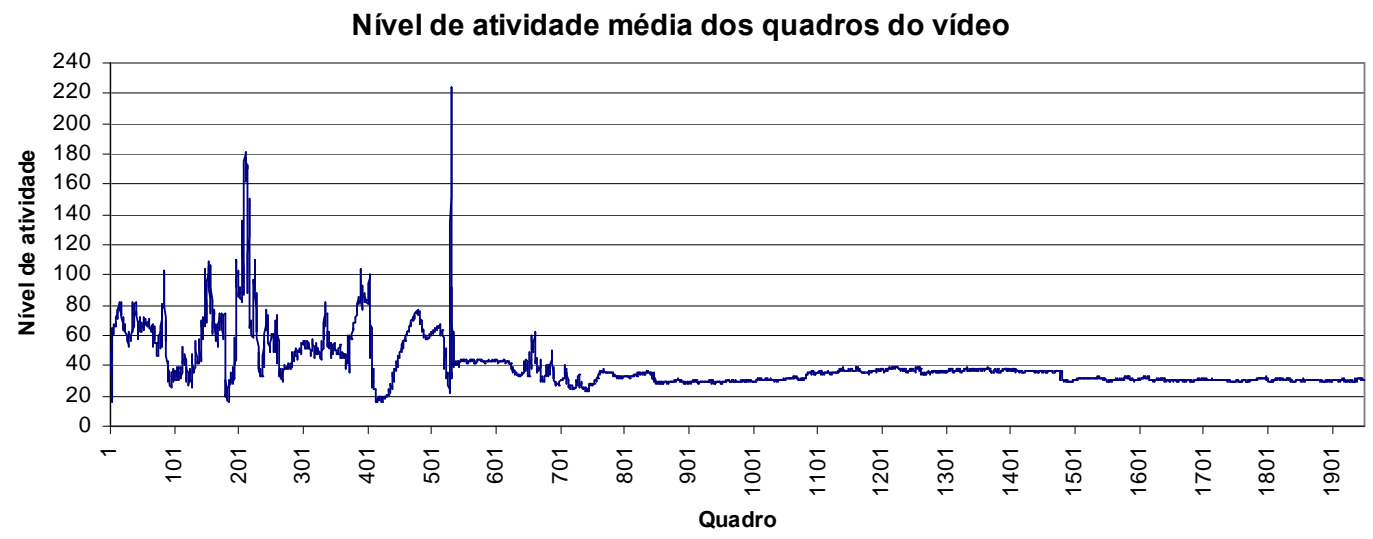

Figura 7.5 - Nível de atividade do vídeo utilizado nos testes.

Pode ser verificado que entre os quadros 1 e 700, o vídeo apresenta variação bastante intensa no nível de atividade e, que após essa parte introdutória da exibição, o vídeo se estabiliza em um nível de atividade menor. Para complementar as informações de atividade do vídeo, é apresentado também, na figura 7.6, um gráfico que mostra a variação da taxa de bits média para cada GOP do vídeo. Conclui-se que há uma correlação entre o nível de atividade e a taxa de bits. Ou seja, à medida que a atividade do vídeo se torna mais intensa, é necessário transmitir mais informações e assim a taxa de bits aumenta.

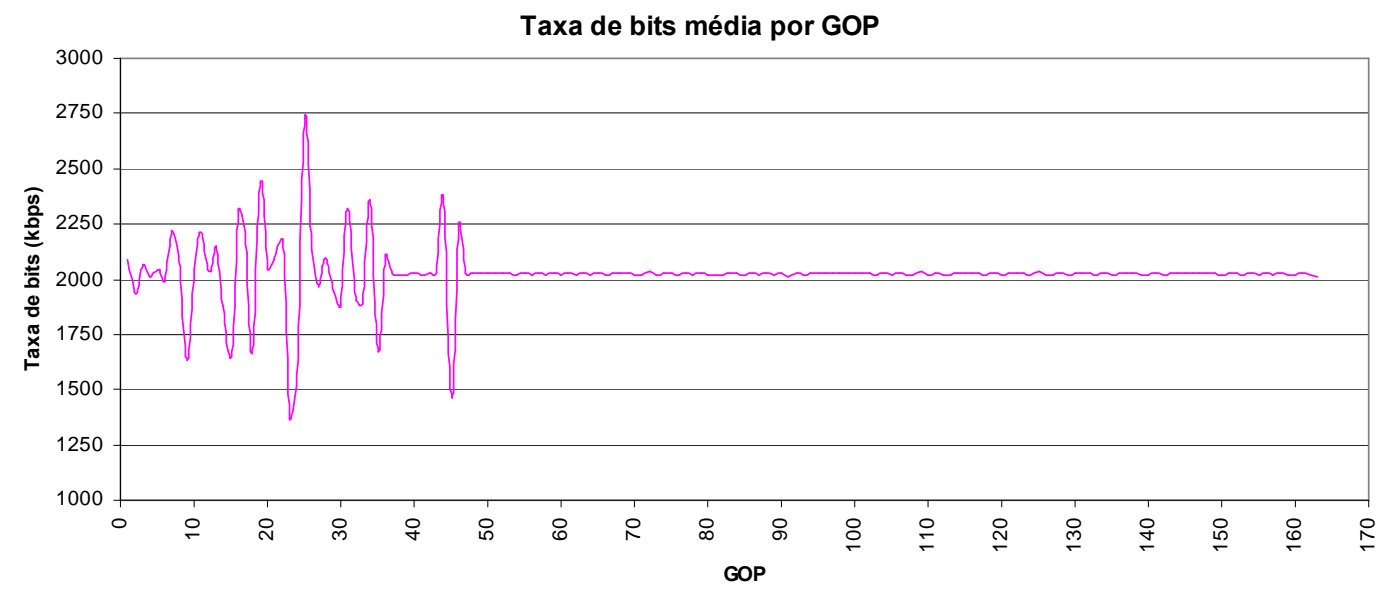

Figura 7.6 - Taxa de bits dos GOPs do vídeo utilizado nos testes. 
O gráfico da figura 7.6 pode ser detalhado para que seja possível analisar em maior profundidade a variação da taxa de bits ao longo dos quadros do vídeo. $\mathrm{Na}$ figura 7.7 são apresentados três gráficos que mostram a taxa de bits para os quadros I, P e B. Observa-se que a taxa de bits necessária para a transmissão dos quadros I é maior do que a necessária para os quadros $\mathrm{P}$ e B. Além disso, nota-se que a taxa de bits nos primeiros quadros I é menor do que aquela nos quadros I finais. Isso se deve ao fato de o vídeo apresentar cenas de intenso movimento no início e pouco movimento no final. Observa-se, portanto, que houve a preocupação, na codificação, de reduzir a quantidade de informação dos quadros I em razão de uma necessidade maior de transmissão de informações de quadros P e B. De fato, verifica-se que no início do vídeo a taxa de bits para os quadros $\mathrm{P}$ e B é maior que no final.

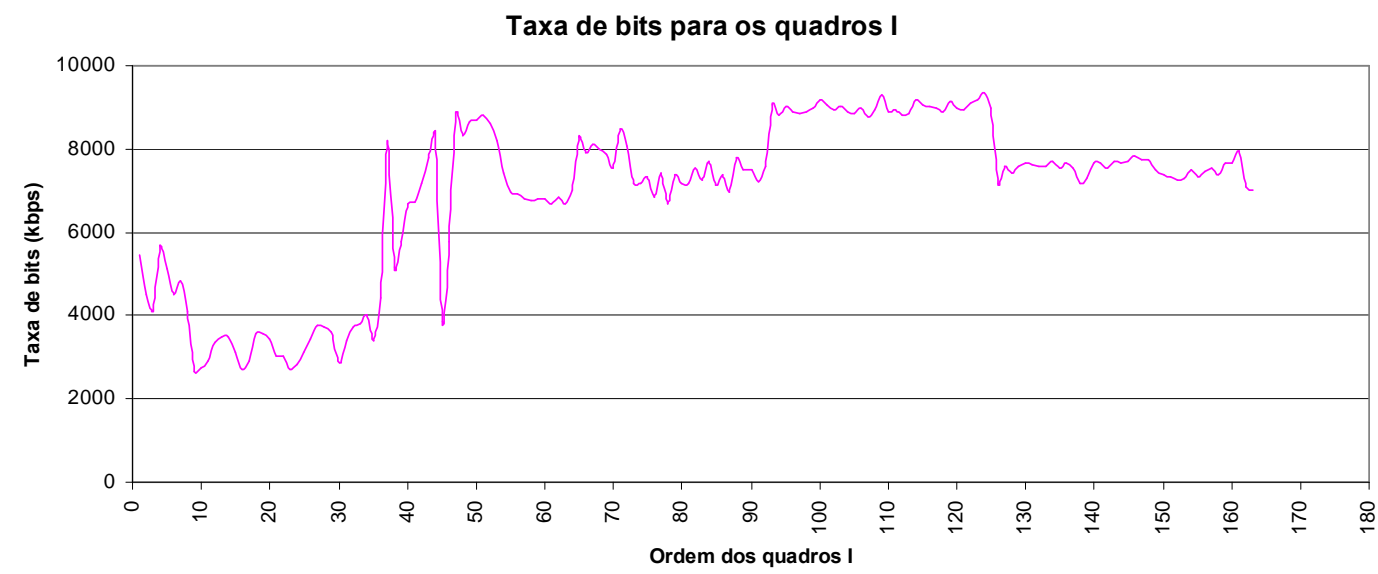

(a)

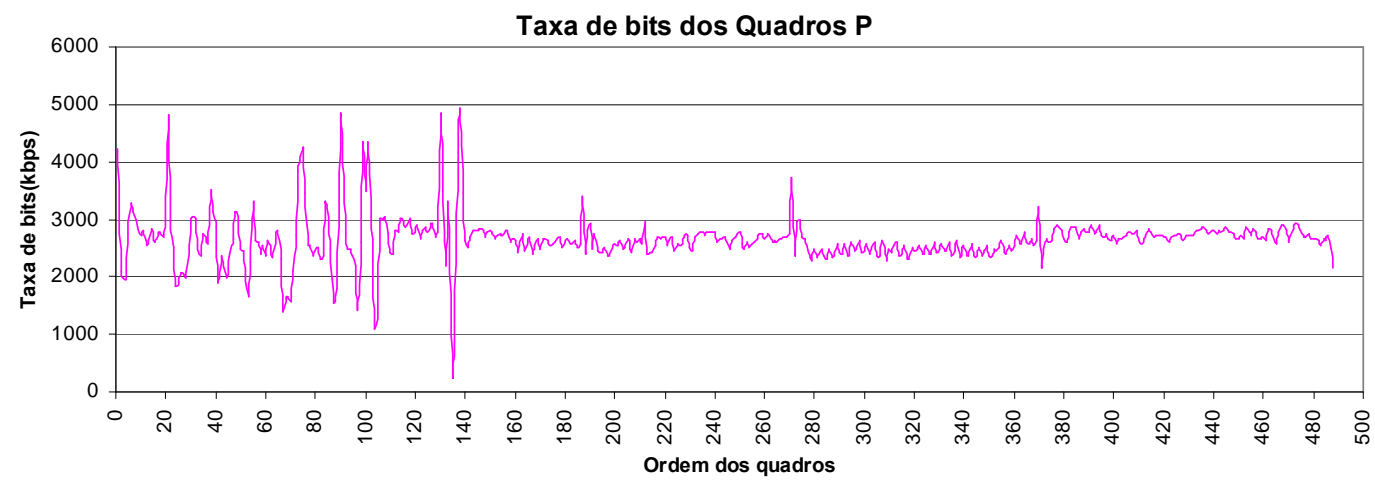

(b) 


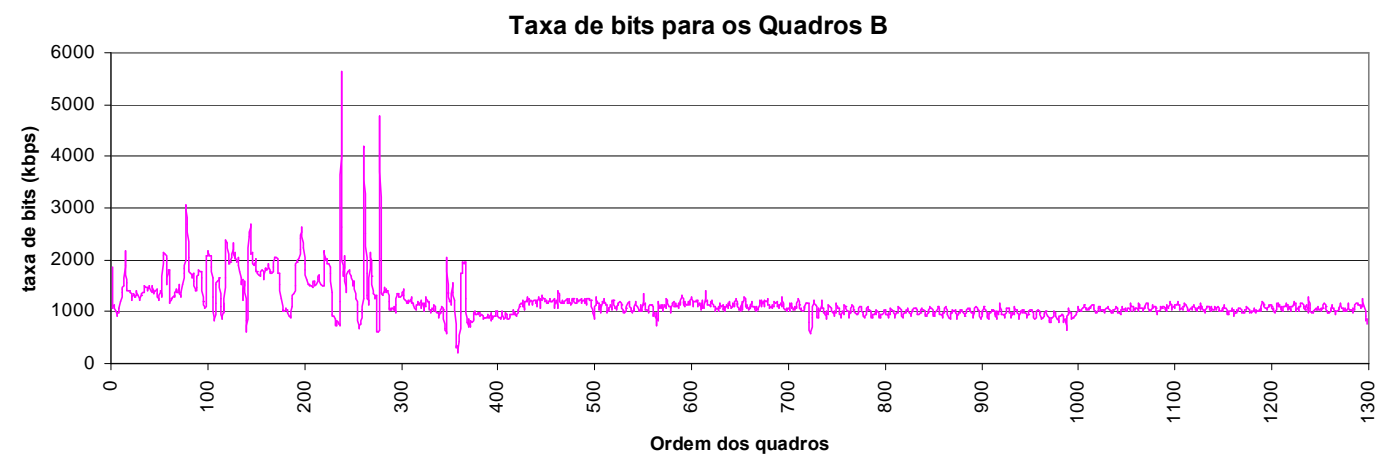

(c)

Figura 7.7 - Taxa de bits para os quadros I, P e B do vídeo de testes.

Como pode ser evidenciado por meio dos gráficos da figura 7.7, as taxas de bits por quadro são variáveis, ou seja, a codificação utilizada é VBR (Variable Bit Rate). A variação da taxa de bits está bastante relacionada a quantização utilizada para cada quadro.

$\mathrm{Na}$ figura 7.8 podem ser verificadas duas situações em que ocorrem variações da taxa de bits quadro a quadro. Em uma região do vídeo em que há bastante movimento (figura 7.8a) pode ser observado que a variação entre quadros sucessivos do vídeo não é tão grande quanto para uma região em que há pouco movimento, figura 7.8b. No segundo caso, pode ser notado que os quadros I se destacam.

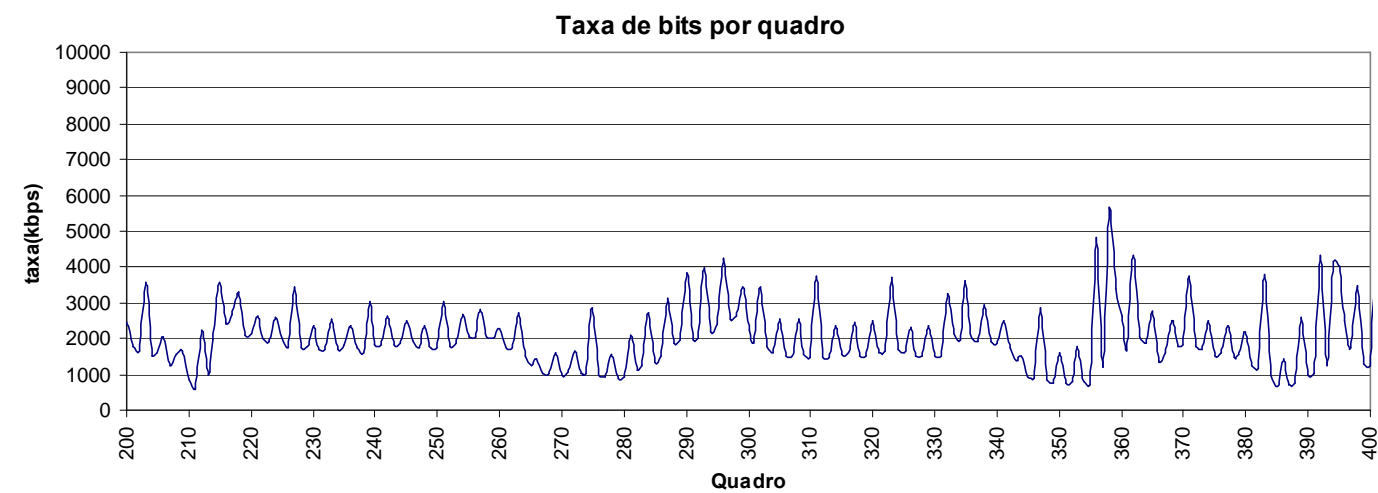

(a) 


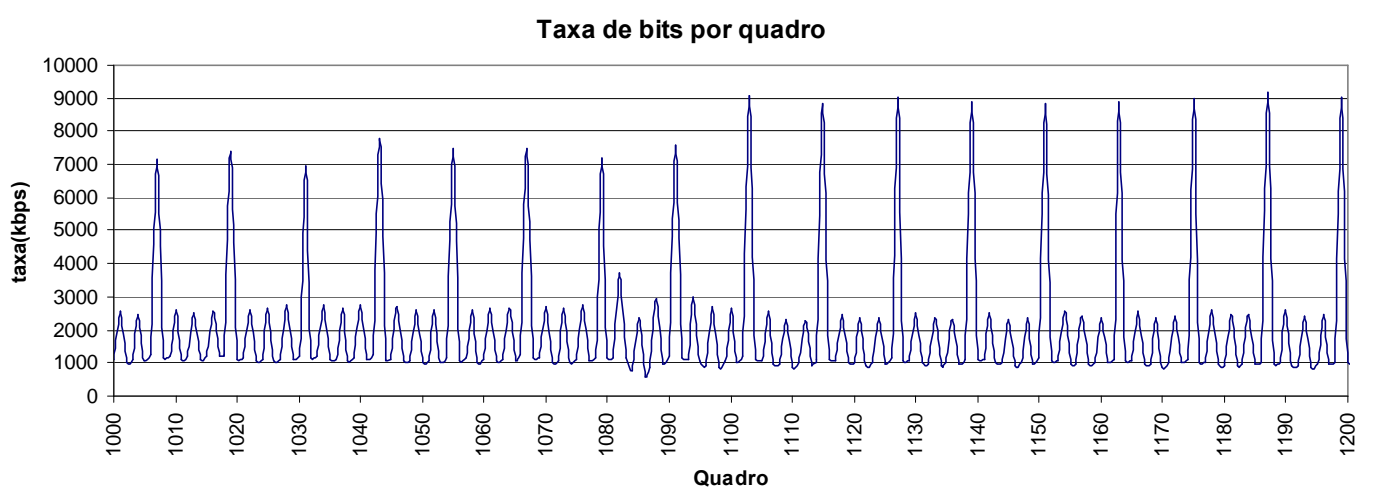

(b)

Figura 7.8 - Variação da taxa de bits em quadros sucessivos do vídeo, (a) região com nível de atividade elevada e (b) região com nível de atividade baixa.

É importante definir também os intervalos entre amostras do PCR consecutivas em termos de tempo. A recomendação do MPEG-2 System (ISO 138181, 1994) é que esse intervalo não seja maior que $100 \mathrm{~ms}$. Investigando-se o comportamento do PCR no fluxo de transporte utilizado nos testes conclui-se que as amostras do PCR são transmitidos a cada $30 \mathrm{~ms}$, em média. O gráfico da figura 7.9 apresenta as informações detalhadas para um trecho do fluxo de transporte correspondente a 180 amostras consecutivas do PCR.

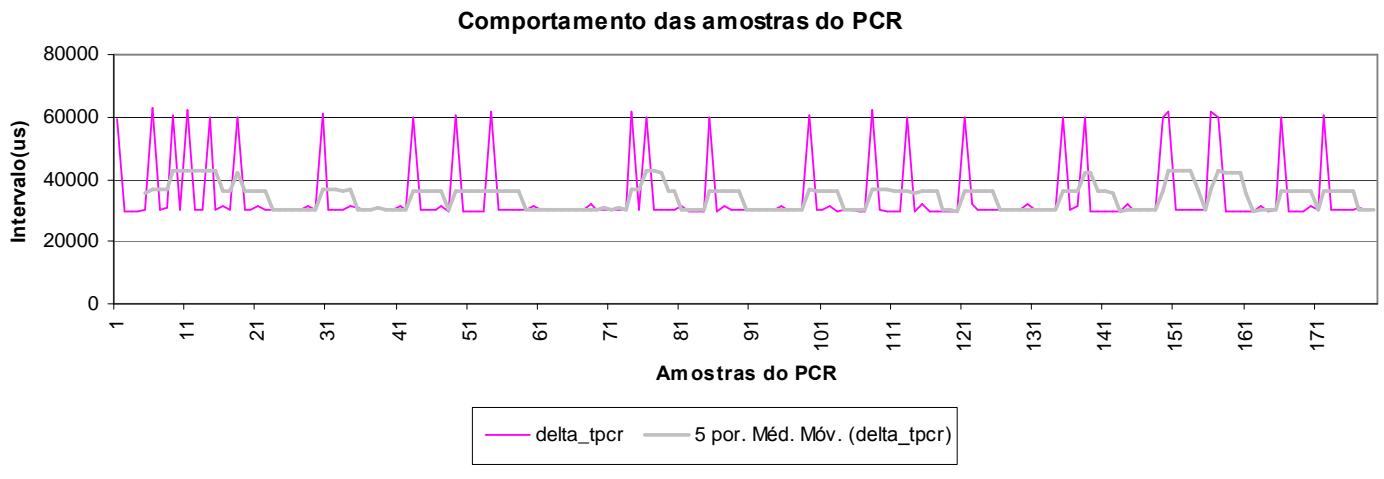

Figura 7.9 - Intervalos entre PCR consecutivos do fluxo de transporte utilizado nos testes. 
Cenários de teste e resultados experimentais

\subsubsection{Metodologia de análise do sincronismo do fluxo de transporte}

Definidos os principais parâmetros do vídeo de testes, pode ser descrita a metodologia adotada para analisar o sincronismo das amostras do PCR e a qualidade objetiva dos vídeos recebidos pelo módulo de recepção, em cada um dos cenários propostos. Nesta seção será apresentada a metodologia utilizada para avaliar o sincronismo do Fluxo de Transporte.

Para registrar os valores de variação de atraso para as amostras do PCR, os seguintes procedimentos foram necessários:

- A configuração de um valor específico de variação de atraso no módulo de controle da rede;

- A transmissão do Fluxo de Transporte (pacotes TS) contendo os 1950 quadros do vídeo;

- O recebimento do Fluxo de Transporte, pelo módulo de ressincronismo, que atua conforme sua configuração, de acordo com o algoritmo habilitado no momento (a escolha do algoritmo é feita na inicialização do módulo);

- A interceptação do Fluxo de Transporte pelo PCRPROBE, que registra informações fundamentais das amostras do PCR, como por exemplo: número de bytes entre amostras consecutivas (delta_bytes), valor da amostra em microssegundos (PCR[i]), diferença entre os valores registrados em amostras do PCR consecutivas (delta_tpcr) e diferença de tempo de chegada de cada amostra (delta_t). Essas informações são armazenadas em um arquivo de saída para posterior análise. O fluxo de transporte não é modificado de nenhuma forma;

- A obtenção, a partir do arquivo de saída do PCRPROBE, de informações da variação de atraso entre amostras do PCR (pcr_jitter), que é calculada a partir das seguintes expressões:

$$
\begin{gathered}
\text { delta_tpcr }=\text { PCR }(i+1)-\text { PCR }(i) ; \\
\text { delta_t }=t(i+1)-t(i) ; \\
\text { pcr_jitter }=\text { delta_tpcr }- \text { delta_t; }
\end{gathered}
$$

onde i é o número da amostra do PCR, que é proporcional ao índice do byte inicial do pacote TS que contém uma amostra de PCR. 
- A elaboração de gráficos a partir dos valores de pcr_jitter e a comparação dos resultados para cada um dos métodos de ressincronização.

\subsubsection{Metodologia de análise da qualidade objetiva do vídeo}

A metodologia utilizada para analisar a qualidade objetiva do vídeo será abordada nesta seção. Conforme descrito na seção 7.1, a variação de atraso na rede é modificada de forma a medir, por meio do módulo de avaliação de qualidade, uma métrica de qualidade objetiva do vídeo para cada valor especificado.

Portanto, para cada valor de variação de atraso desejado são efetuados os seguintes procedimentos:

- A configuração de um valor específico de variação de atraso no módulo de controle da rede;

- A transmissão e recepção do Fluxo de Transporte (pacotes TS) contendo os 1950 quadros do vídeo;

- A armazenagem dos pacotes TS recebidos pelo módulo de recepção em um arquivo;

- A demultiplexação do vídeo comprimido do Fluxo de Transporte armazenado em arquivo;

- O cálculo da métrica de qualidade objetiva (PSNR) para cada um dos 1950 quadros do vídeo recebido;

- O cálculo da média dos 1950 valores da métrica de qualidade de vídeo, obtendo, assim, um valor representativo do vídeo como um todo.

Para exemplificar essa metodologia na figura 7.10 é apresentado um gráfico com os valores de PSNR para uma variação de atraso de $100 \mu \mathrm{s}$. 


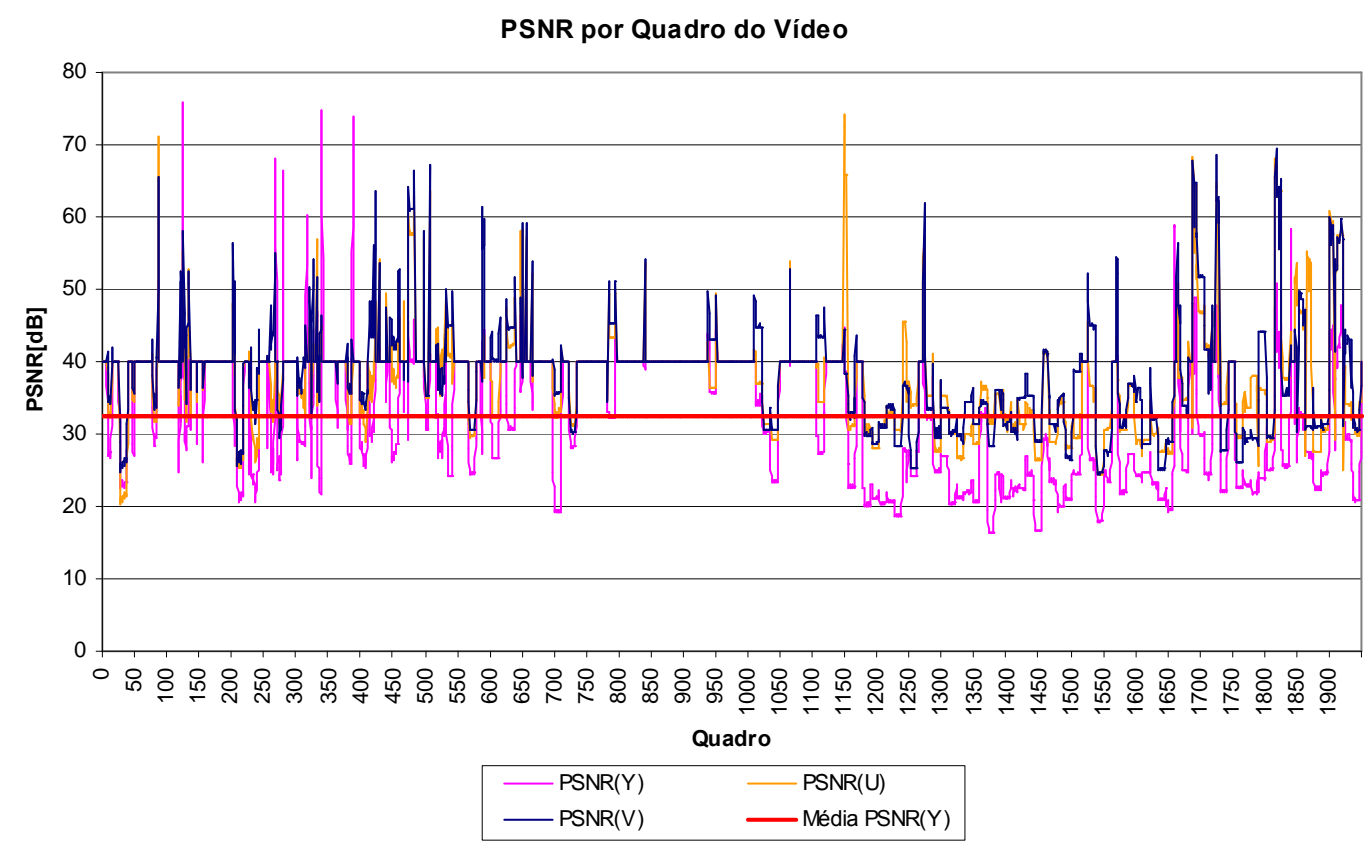

Figura 7.10 - Variação do PSNR para todos os quadros do vídeo de testes.

Esses procedimentos são repetidos para cada valor de variação de atraso que se deseja analisar. Por conseguinte, ao final de cada cenário de testes, são obtidas diversas médias do PSNR para todo o vídeo, cada uma delas associada a um valor de variação de atraso. Essas médias são, então, reunidas em um gráfico para que se possa analisar o comportamento do PSNR a medida que é modificada a variação de atraso.

\subsubsection{Cenário 1: Influência dos parâmetros de QoS na qualidade objetiva do vídeo recebido}

Neste cenário foram variados os parâmetros de QoS, conforme a tabela 7.2 a seguir, de forma a atingir uma qualidade subjetiva do vídeo correspondente ao nível 1 da recomendação da ITU-R 500-3.5 (CCIR 500-3, 1986), ou seja, equivalente ao valor da métrica MOS (Mean Opinion Score) definida nessa recomendação. 
Tabela 7.2 - Intervalos de variação para os parâmetros de QoS para atingir um MOS equivalente a 1.

\begin{tabular}{|c|c|c|}
\hline Parâmetro de QoS & Nível Inferior & Nível Superior \\
\hline Atraso & $0 \mathrm{~ms}$ & $1000 \mathrm{~ms}$ \\
\hline Variação de Atraso & $0 \mu \mathrm{s}$ & $400 \mu \mathrm{s}$ \\
\hline Perda de Pacotes & $0 \%$ & $10 \%$ \\
\hline Duplicação de Pacotes & $0 \%$ & $10 \%$ \\
\hline
\end{tabular}

Esses limites foram definidos avaliando-se a qualidade subjetiva do vídeo. Para exemplificar como a qualidade do vídeo variou entre esses limites, são apresentados na figura 7.11 alguns quadros do vídeo com diversos valores de perda de pacotes associados. Nota-se que à medida que é aumentada a porcentagem de perda de pacotes, o vídeo torna-se cada vez menos inteligível e, em conseqüência, a exibição torna-se pior a cada aumento da perda de pacotes. Observa-se ainda que nesses quadros há perdas de slices inteiros (7\% e $10 \%$ de perda de pacotes), ocorrendo também perda de vetores de movimento (5\% de perda de pacotes) enquanto que em outros quadros somente regiões esparsas do quadro são afetadas ( $1 \%$ e $3 \%$ de perda de pacotes).

Apesar de refletirem algumas perdas de qualidade, os quadros apresentados na figura 7.11 mostram parcialmente a qualidade subjetiva do vídeo, pois a exibição sucessiva de quadros com perdas semelhantes às apresentadas nessa figura incomoda sobremaneira o espectador, sendo justamente essa sensação a ser levada em consideração na determinação dos limites da tabela 7.2. 
Cenários de teste e resultados experimentais

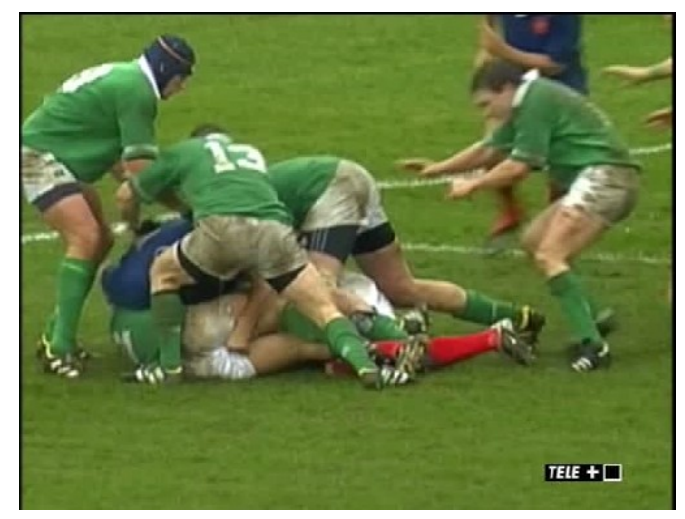

(a)

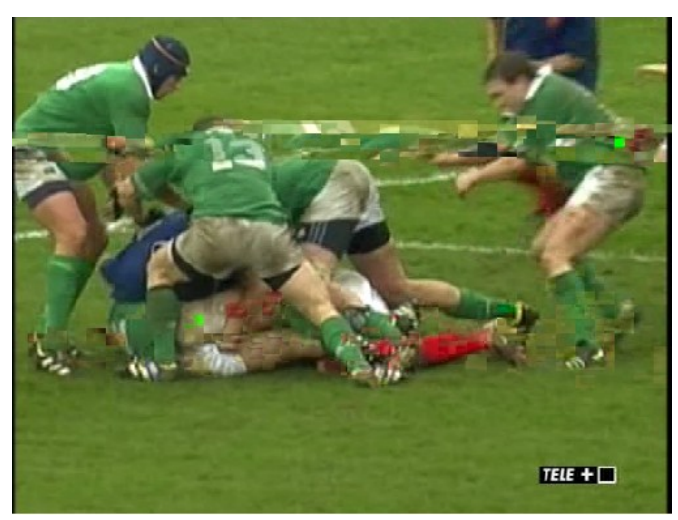

(c)

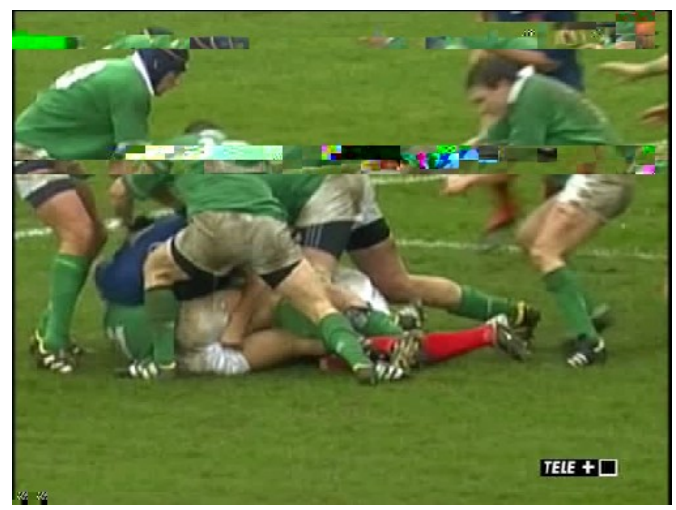

(e)

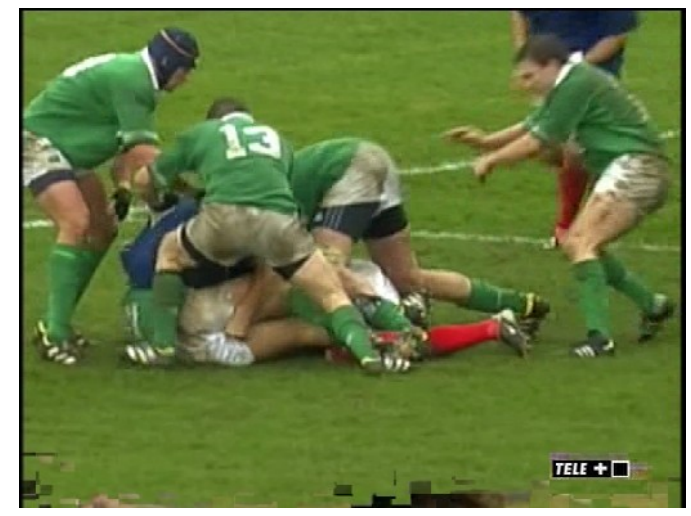

(b)

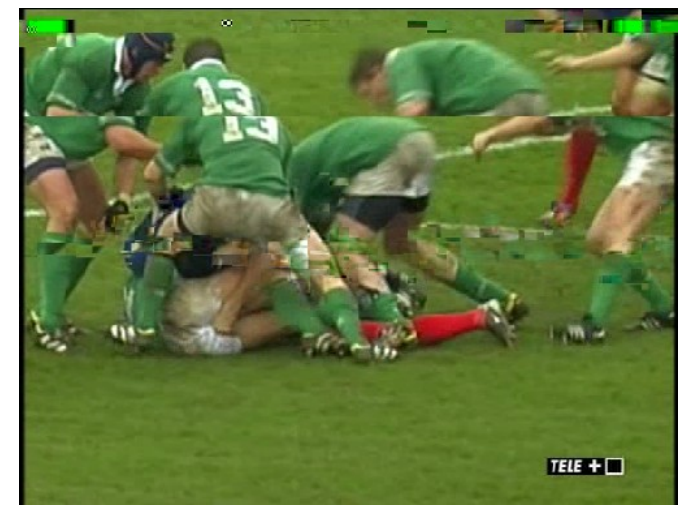

(d)

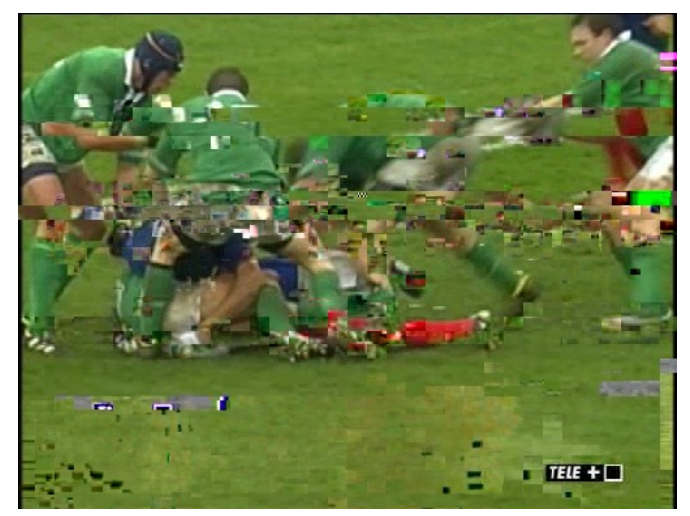

(f)

Figura 7.11 - Quadros do vídeo de trabalho em diversas situações de perda de pacotes, (a) $0 \%$, (b) $1 \%$, (c) $3 \%$, (d) $5 \%$, (e) $7 \%$ e (f) $10 \%$.

Os resultados da variação dos parâmetros de QoS foram reunidos em alguns gráficos apresentados na figura 7.12, que demonstram como se comporta a qualidade objetiva do vídeo com a variação desses parâmetros entre os limites da tabela 7.2. Segundo Singh (SINGH, 2005), a qualidade do vídeo somente pode ser considerada 
excelente quando o valor do PSNR for maior que $33 \mathrm{~dB}$. Nota-se, portanto, que nos gráficos de perda de pacotes, de duplicação de pacotes e de variação de atraso, os valores de PSNR variam até valores abaixo de $33 \mathrm{~dB}$ para as condições limites, sendo confirmada a estratégia de avaliar a qualidade subjetiva para construir a tabela 7.2 pela avaliação da qualidade objetiva.

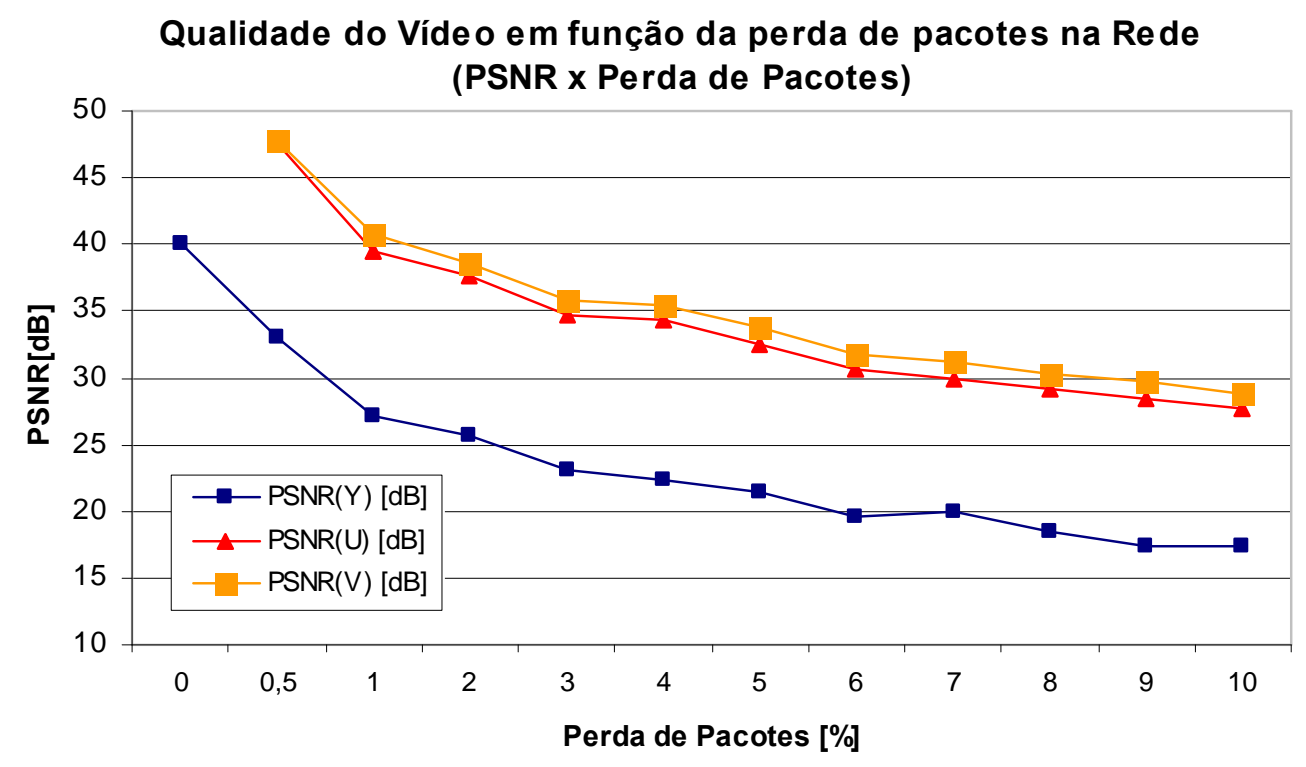

(a)

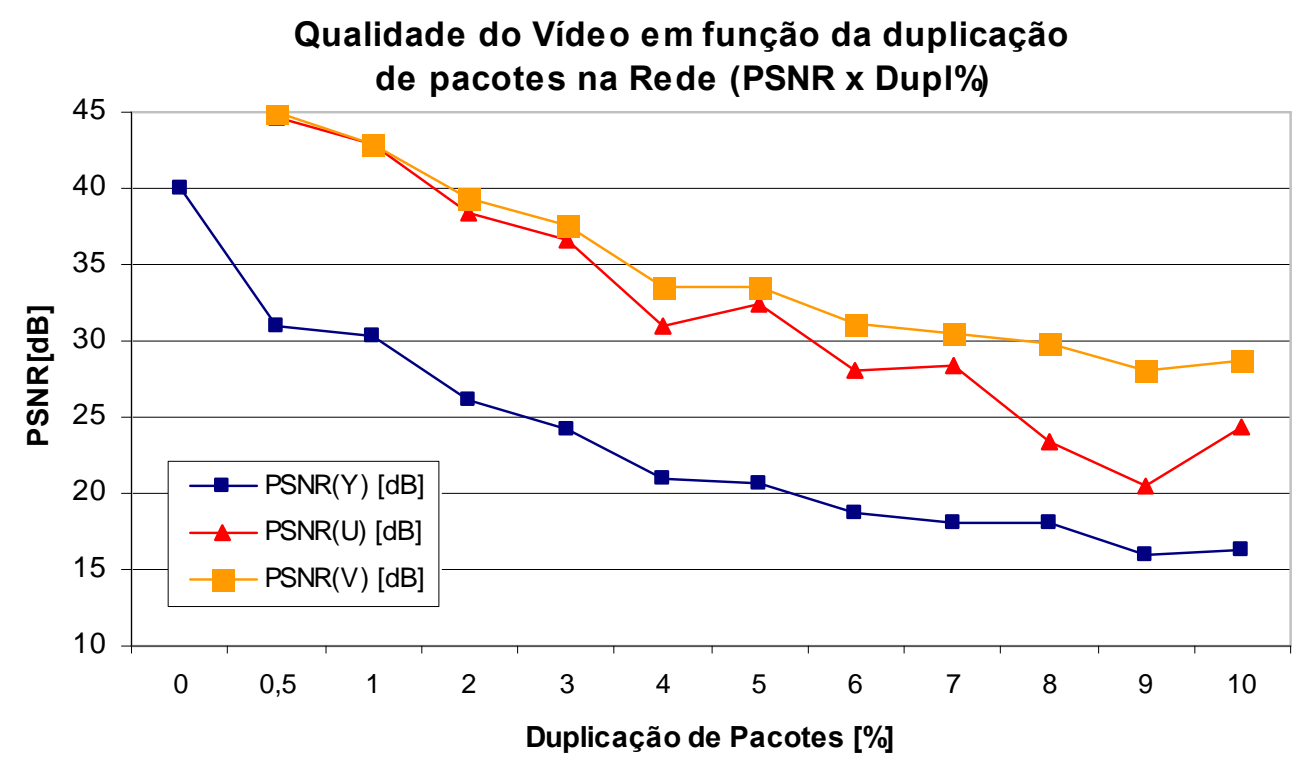

(b) 


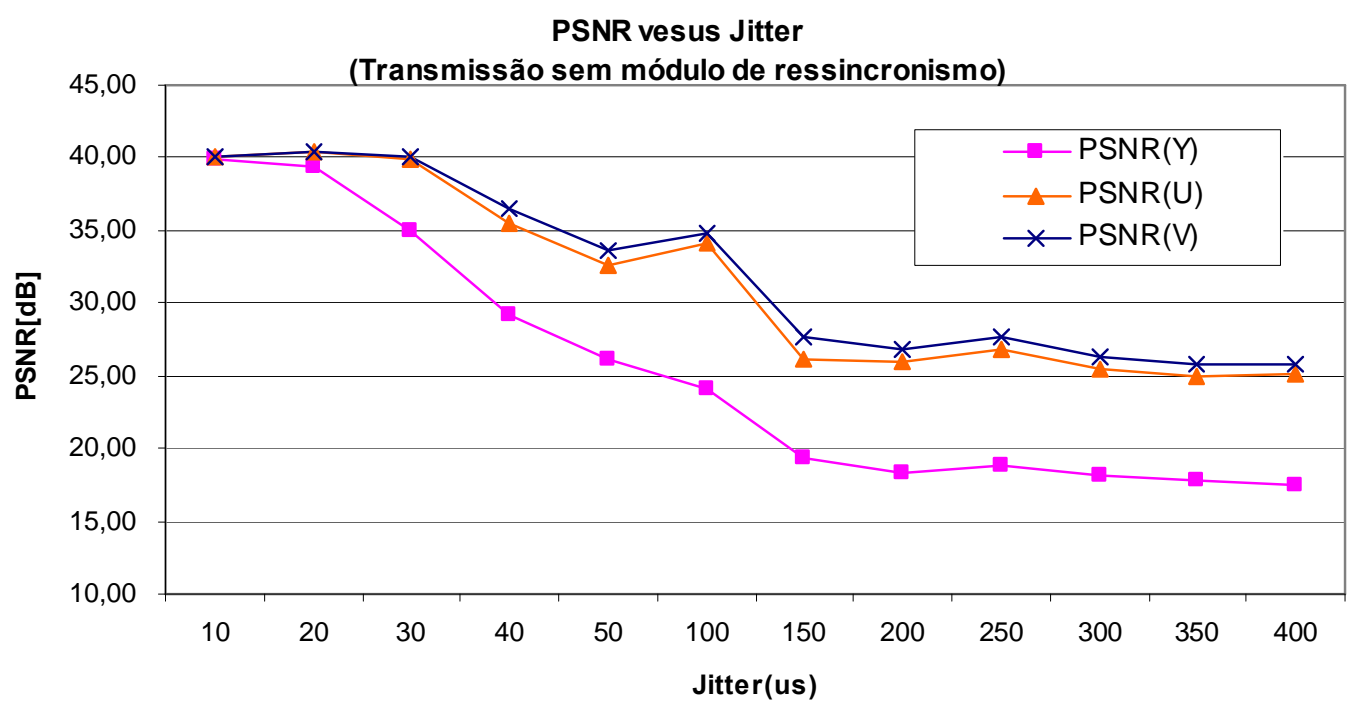

(c)

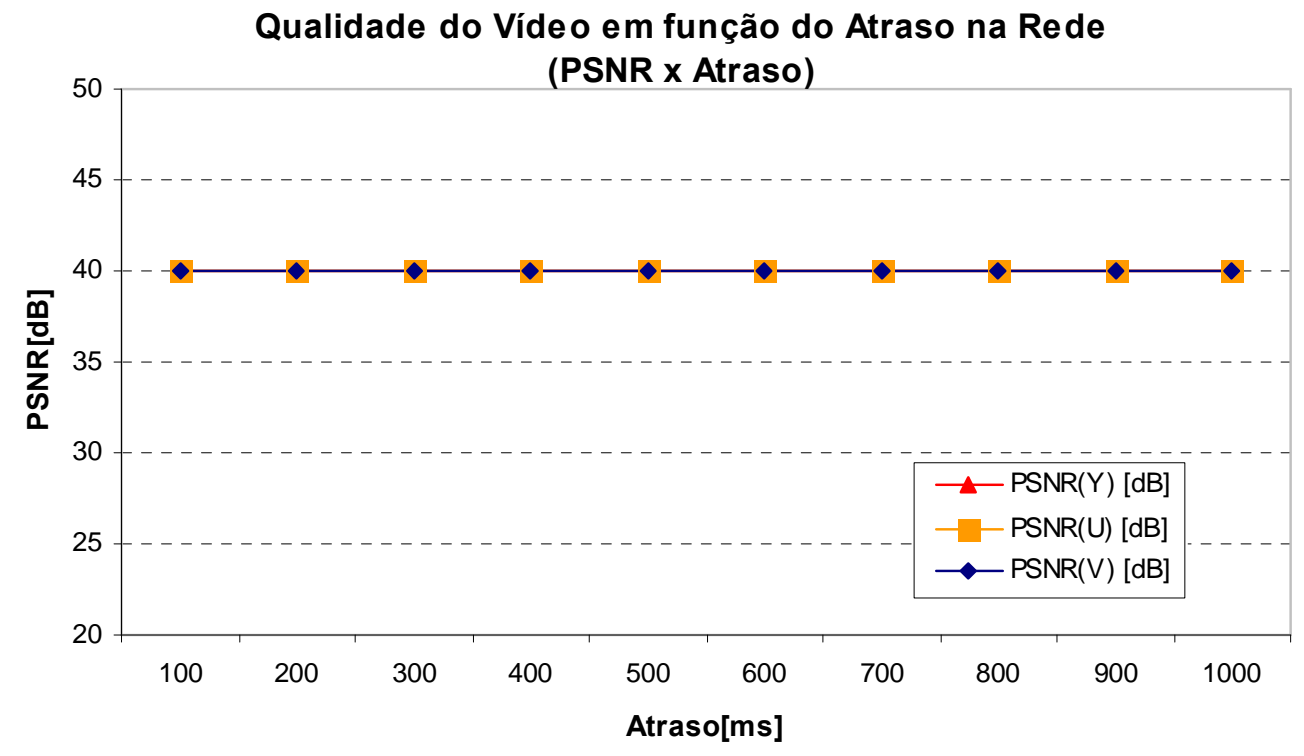

(d)

Figura 7.12 - Gráficos do PSNR em função de parâmetros de QoS, (a) perda de pacotes, (b) duplicação de pacotes, (c) variação de atraso e (d) atraso.

A partir dos gráficos da figura 7.12 pode se concluir que os parâmetros de QoS tem uma influência bastante significativa na qualidade do vídeo recebido, excetuando-se o atraso que não determinou variação alguma no PSNR do vídeo recebido. $\mathrm{O}$ atraso em si não comprometeria a qualidade do vídeo recebido, pois 
Cenários de teste e resultados experimentais

todos os pacotes TS foram atrasados igualmente no teste efetuado, o que não afeta o sincronismo, o que determina uma exibição perfeita.

Quanto aos outros parâmetros, os gráficos sugerem que os efeitos da perda ou da duplicação de pacotes são mais intensos que os da variação de atraso, pois o PSNR teve uma queda mais acentuada para a perda/duplicação de pacotes. Entretanto, como as duas grandezas não estão sendo avaliadas na mesma unidade (a perda de pacotes varia em porcentagem e a variação de atraso em microssegundos), não podemos chegar a tal conclusão. No entanto, pode ser observado que tanto a perda/duplicação de pacotes quanto a variação de atraso influem muito na qualidade do vídeo quando não são utilizados métodos de ressincronização.

Os gráficos indicam também que a luminância (Y) é mais afetada que a crominância (U e V). Isso pode ser explicado pelo fato de a crominância fornecer informações de cores e a luminância de intensidade dos pixels. Assim, a perda de algum macrobloco de crominância altera somente as cores que são exibidas. Já a perda de um macrobloco de luminância, altera a inteligibilidade do quadro, o que se reflete em valores menores de qualidade objetiva do vídeo (PSNR).

Entretanto, comparando-se os limites de variação de atraso alcançados com os intervalos entre amostras do PCR consecutivas (em torno de 30ms). verifica-se que a degradação do PSNR ocorre mais rápido que o esperado, pois a ordem de grandeza da máxima variação de atraso alcançada foi de centenas de microssegundos enquanto a distância entre as amostras do PCR é da ordem de dezenas de milisegundos. Além disso, era esperado que a degradação do PSNR fosse sentida apenas quando a variação de atraso atingisse pelo menos $1 \mathrm{~ms}$ ou mais.

Essa degradação pode ser explicada pelo comportamento do módulo de controle da rede. Investigando-se de forma mais aprofundada a atuação do módulo de controle da rede pode-se observar que, em situações específicas, ocorre um reordenamento de pacotes. Para ilustrar como esse fenômeno acontece, foram feitas algumas simulações com o intuito de registrar a que tipo de quadro (I, P ou B) pertenceria um determinado pacote TS recebido pelo módulo de recepção. Ou seja, foi registrada a ordem de chegada de pacotes no receptor para comprovar a tese do reordenamento de pacotes. 
Os resultados da investigação descrita no parágrafo anterior são apresentados na figura 7.13 para uma variação de atraso na rede de $5 \mathrm{~ms}$. Foram utilizadas as métricas apresentadas por Przybylski (PRZYBYLSKI; BELTER; BINCZEWSKI, 2005) para quantificar o reordenamento de pacotes.

Nota-se um comportamento distinto entre dois cenários, com e sem a atuação do módulo de controle da rede, pois as ocorrências de um determinado tipo de quadro não são coincidentes para um mesmo instante de tempo. Ao inserir o módulo de controle da rede, a ordem dos pacotes TS torna-se diferente da original, o que indica que os pacotes estão sendo reordenados de alguma forma. Uma hipótese razoável seria supor que determinados pacotes chegam ao módulo de controle da rede e sofrem atrasos maiores que seus predecessores, de forma que um pacote fica retido no módulo de controle da rede enquanto seus predecessores são retransmitidos. De fato, a documentação do Nistnet ${ }^{48}$ indica que essa hipótese é possível no caso de a variação de atraso especificada ser maior que o atraso fim-afim estabelecido. Em outras palavras, caso seja especificado um atraso de trânsito na ordem de microssegundos e a variação de atraso, na ordem de milisegundos, pode ocorrer reordenamento de pacotes.

${ }^{48}$ NISTNET. Disponível em: <http://snad.ncsl.nist.gov/nistnet/>. Acesso em: 30 jan. 2006. 


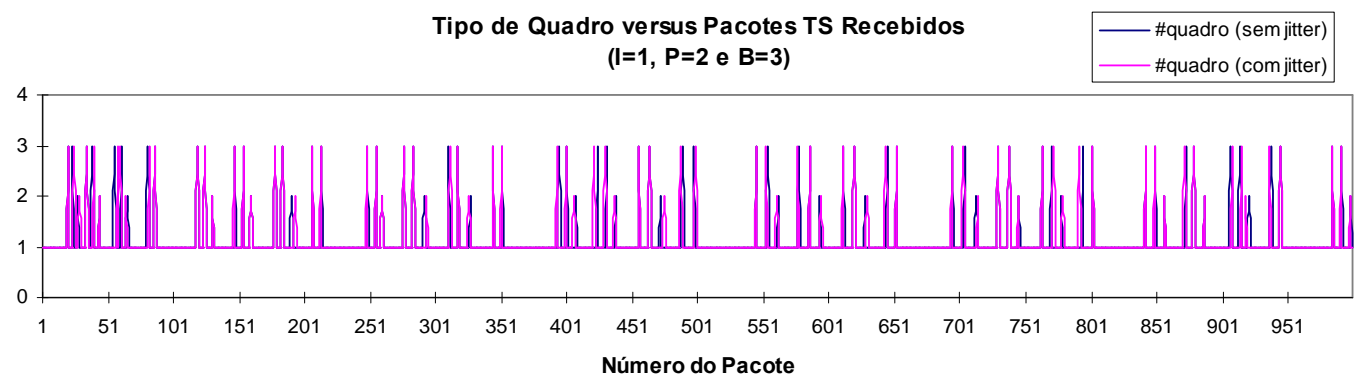

(a)

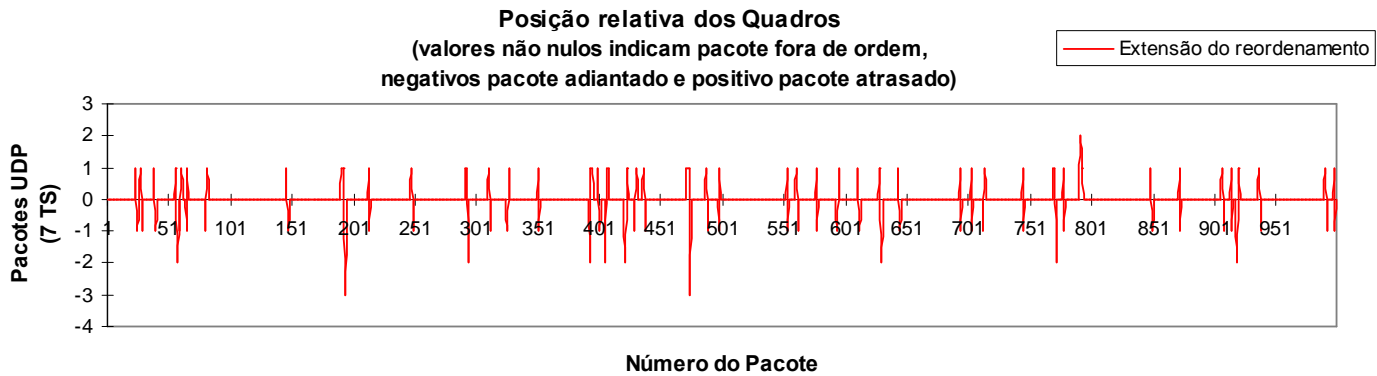

(b)

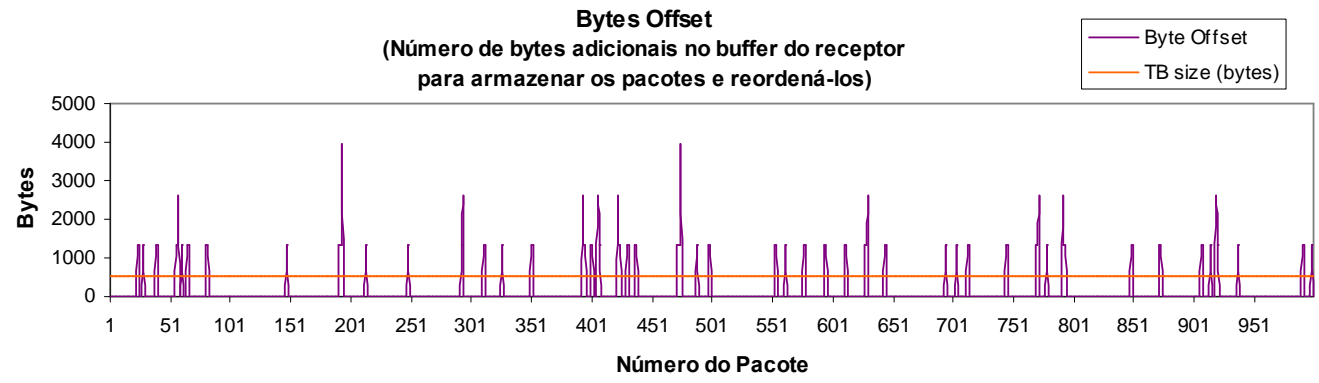

(c)

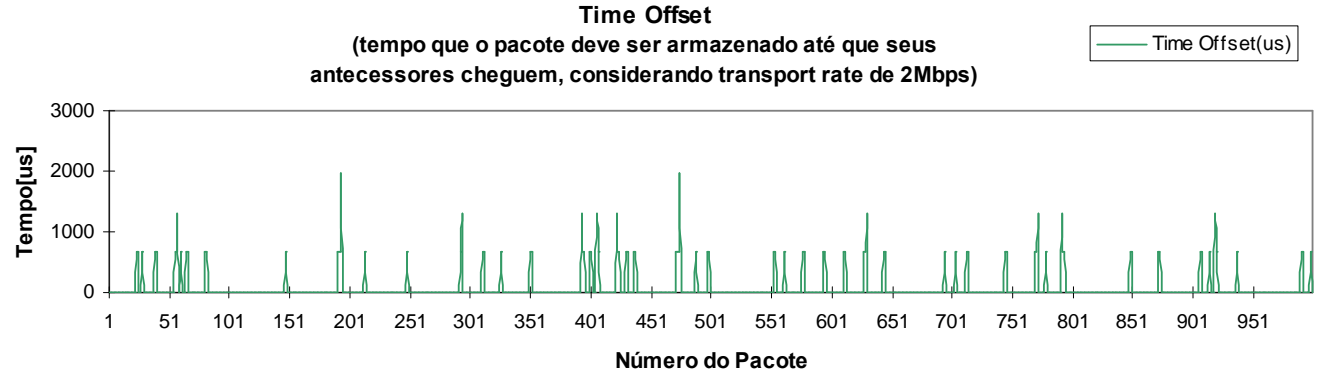

(d)

Figura 7.13 - Reordenamento de Pacotes, (a) tipo de quadro registrado, (b) posição relativa dos quadros, (c) Bytes Offset, e (d) Time Offset. 
Cenários de teste e resultados experimentais

A partir dos gráficos da figura 7.13 verifica-se que vários pacotes UDP estão fora de ordem no fluxo de transporte. $\mathrm{O}$ fato dos pacotes TS serem encapsulados em pacotes UDP com campo de dados de 1316 bytes, contendo sete pacotes TS de 188 bytes por pacote UDP, agrava ainda mais os efeitos do reordenamento, pois cada pacote UDP reordenado causa o reordenamento de sete pacotes TS. Outro resultado relevante refere-se ao tamanho do buffer adicional que seria necessário para reordenar os pacotes TS. Como o buffer do fluxo de transporte, segundo o modelo de temporização padronizado pelo MPEG2 System (ISO 13818-1, 1994), tem tamanho fixo de 512 bytes, supõe-se que, em grande parte das implementações de receptores para fluxos de transporte MPEG-2, os pacotes excedentes seriam descartados.

O fato de não ser possível simular valores de variação de atraso na rede compatíveis com o intervalo entre PCRs (em torno de 30ms), utilizando o módulo de controle da rede, conforme especificado no capítulo 6, prejudica os cenários 2, 3 e 4 . Para o máximo valor de variação de atraso alcançado, ou seja, $400 \mu \mathrm{s}$, não seria possível indicar se há impacto relevante da variação de atraso no sincronismo do fluxo de transporte, pois tal variação na chegada de uma amostra do PCR não modifica significativamente nem a taxa de bits do fluxo de transporte, nem o preenchimento do buffer do receptor. Portanto, a investigação do comportamento da qualidade objetiva do vídeo recebido em função da variação de atraso da rede fica, assim, prejudicada.

Os resultados apresentados nas seções a seguir demonstram, no entanto, como se comportam os algoritmos desenvolvidos para o módulo de ressincronismo e sua atuação na manutenção do sincronismo do fluxo de transporte. Apesar de ocorrer reordenamento de pacotes isolados, é possível comprovar que, ao inserirmos o módulo de ressincronismo, o intervalo entre amostras do PCR é mantido constante. Em outras palavras, o módulo de ressincronismo diminui a variação de atraso das amostras do PCR. Conseqüentemente, a taxa de bits do fluxo de transporte e o preenchimento do buffer do receptor não são alterados significativamente em condições relevantes de variação de atraso na rede. 
Cenários de teste e resultados experimentais

\subsubsection{Cenário 2: Avaliação do método de inserção de pacotes nulos isoladamente}

O primeiro teste visou avaliar o desempenho do algoritmo de inserção de pacotes nulos, sendo o foco principal do módulo de ressincronismo atuar na variação de atraso para as amostras do PCR.

A razão principal para serem estudados somente os efeitos do ressincronismo na variação de atraso, na avaliação do módulo de ressincronismo, é simples. $\mathrm{O}$ módulo de ressincronismo não pode impedir os efeitos da perda de pacotes, pois uma vez descartados os pacotes, eles não podem ser recuperados. A perda de pacotes pode acontecer em diversos pontos do framework, por exemplo, nos roteadores da rede, quando da ocorrência de congestionamentos; ou no receptor, quando os buffers de decodificação e apresentação transbordam devido a perdas de sincronismo.

A atuação do método de inserção de pacotes nulos é limitada aos casos onde as amostras do PCR estejam adiantados, como descrito nos capítulos anteriores. O teste foi efetuado em duas etapas:

- Etapa 1: fixou-se a variação de atraso no módulo de controle da rede em $5 \mathrm{~ms}$ e, por meio do módulo de monitoração das características das amostras do PCR (PCRPROBE), foram efetuadas medidas da variação de atraso entre amostras do PCR, com e sem a atuação do módulo de ressincronismo;

- Etapa 2: a variação de atraso foi sendo modificada de maneira similar à seção 7.2.2, ou seja, até que a qualidade subjetiva do vídeo fosse visualmente ruim. Essas modificações, no entanto, foram feitas com o módulo de ressincronismo ativo. Foram efetuadas medidas da qualidade objetiva do vídeo para cada valor de variação de atraso da rede.

Antes de apresentar os resultados obtidos nas duas etapas do teste, é necessário verificar os efeitos de uma variação de atraso fixada em $5 \mathrm{~ms}$ para as amostras do PCR. O PCRPROBE permitiu quantificar esses efeitos. A figura 7.14 mostra um gráfico onde pode ser verificado que amostras do PCR consecutivas são adiantadas e atrasadas significativamente devido a variação de atraso na rede. 


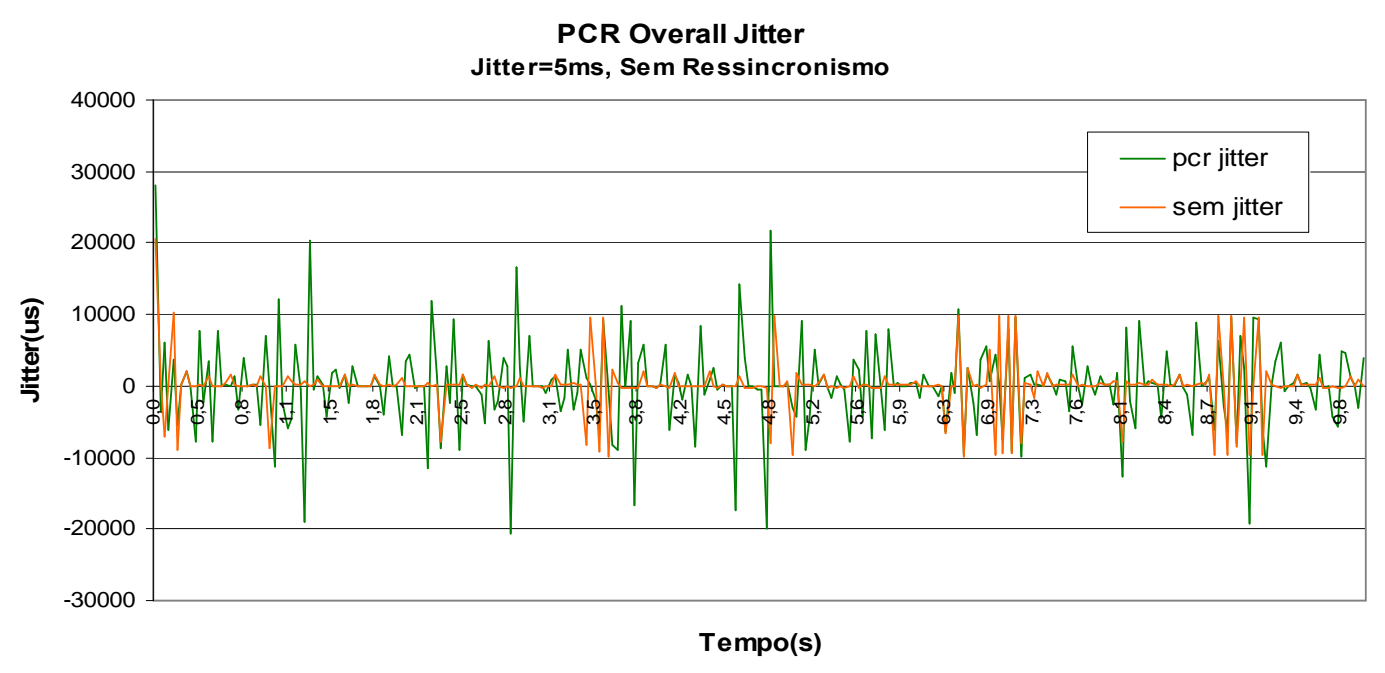

Figura 7.14 - Gráfico da variação de atraso das amostras do PCR (PCR Jitter) para a variação de atraso na rede de $5 \mathrm{~ms}$.

A atuação do algoritmo de inserção de pacotes nulos visa corrigir o sincronismo das amostras do PCR, quando elas estiverem adiantadas. Ou seja, quando a recepção de um pacote que contém uma amostra do PCR estiver adiantada em relação ao tempo correspondente registrado no PCR, são inseridos pacotes TS nulos que atrasam a chegada dessa amostra no receptor. Os resultados do desempenho do algoritmo podem ser comprovados na figura 7.15. Nota-se que os picos positivos do gráfico 7.15 não estão mais presentes, ou seja, as amostras do PCR adiantadas foram corrigidos. 


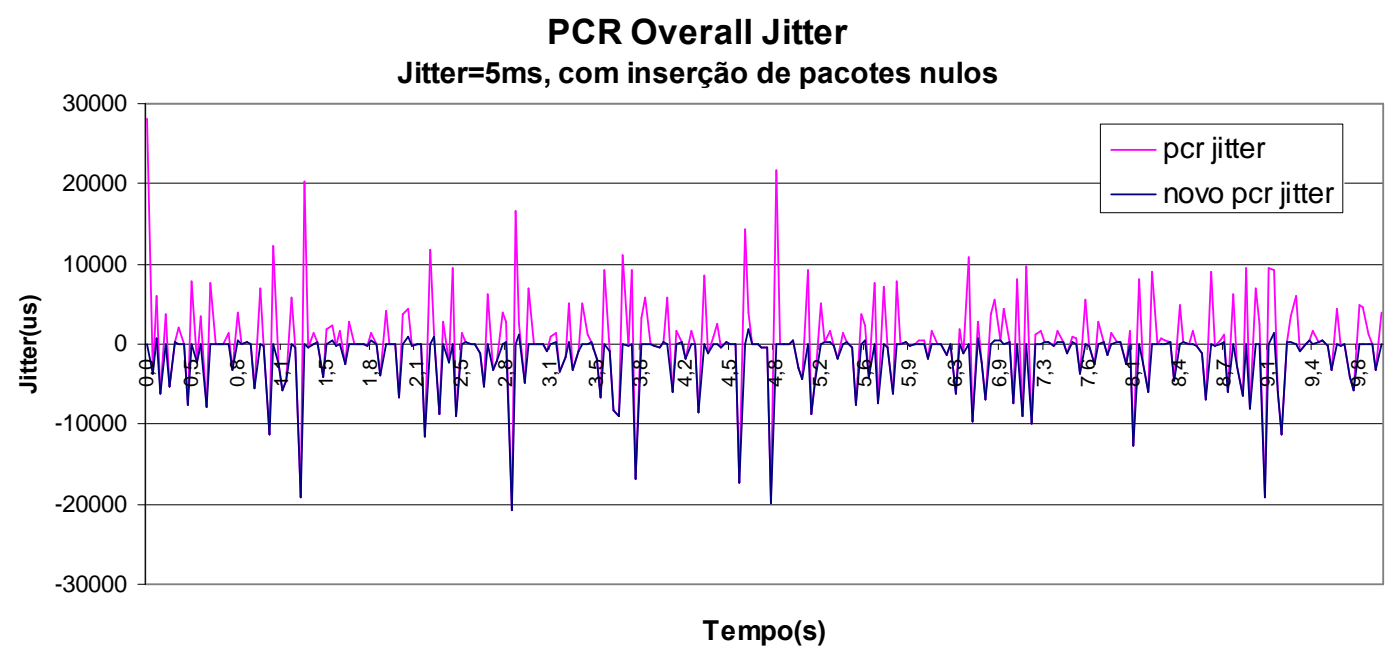

Figura 7.15 - Gráfico da variação de atraso das amostras do PCR (pcr_jitter) para a variação de atraso na rede de $5 \mathrm{~ms}$, com a atuação do módulo de ressincronismo implementando o algoritmo de inserção de pacotes nulos.

As duas figuras anteriores (figuras 7.14 e 7.15) comprovam a atuação do algoritmo de inserção de pacotes nulos. Os resultados obtidos para a etapa dois, por sua vez, são apresentados na figura 7.16 por meio de um gráfico do PSNR em função da variação de atraso.

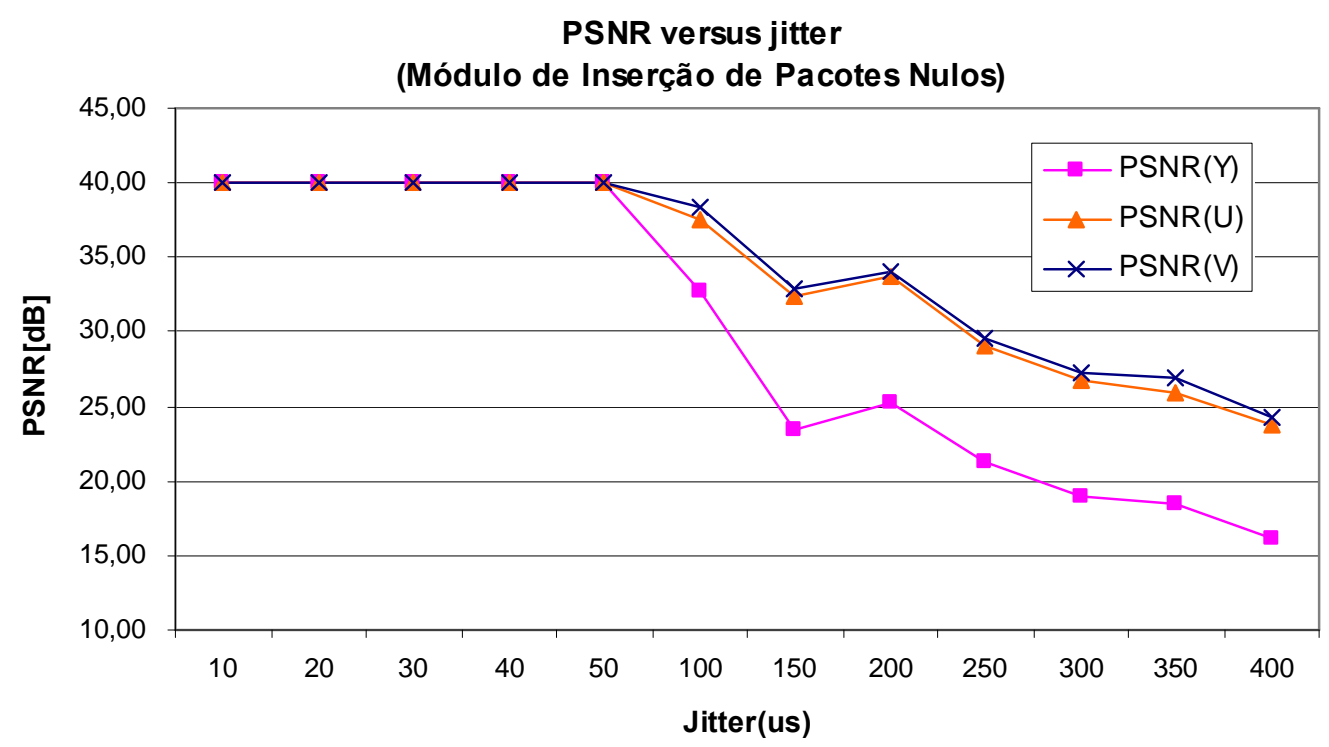

Figura 7.16 - Gráfico do PSNR em função da variação de atraso para o cenário 2. 
Cenários de teste e resultados experimentais

Pode ser evidenciado a partir do gráfico da figura 7.16 que a qualidade do vídeo é mantida dentro do nível excelente $(33 \mathrm{~dB})$ para valores de variação de atraso entre 0 e $100 \mu$ s. Comparando-se o gráfico da figura 7.16 com o gráfico da figura 7.12 (c), nota-se que a métrica de qualidade tornou-se menos sensível a variações de atraso, pois o PSNR só deixa a faixa de qualidade excelente para valores de variação de atraso acima de $100 \mu \mathrm{s}$. Esse resultado, portanto, fornece subsídios para a comprovação da hipótese de que o sincronismo influencia na exibição correta dos fluxos elementares. Entretanto,é preciso ter em mente que os dados obtidos são somente indicadores de uma tendência.

\subsubsection{Cenário 3: Avaliação do ressincronismo implementado por meio dos métodos de inserção de pacotes nulos e de descarte de pacotes dos quadros B}

O módulo de ressincronismo precisa ser avaliado em sua totalidade, ou seja, operando com os algoritmos para corrigir o sincronismo do PCR tanto para as amostras atrasadas como para as adiantadas.

Nesta seção, são apresentados os resultados para o método de ressincronização por meio do descarte de pacotes dos quadros B e, na próxima seção, os resultados para o método de requantização de slices do vídeo comprimido. Uma posterior análise comparativa é feita na seção 7.3 a partir dos resultados obtidos e apresentados nas seções 7.2.1 a 7.2.5. Os resultados são expressos por meio de gráficos da variação de atraso nas amostras do PCR (pcr_jitter), em função do tempo, e do PSNR, em função da variação de atraso, de maneira similar aos resultados da seção 7.2.3.

A figura 7.17 apresenta um gráfico, por meio do qual pode ser observada a atuação do algoritmo de descarte de pacotes de quadros B. Nota-se que apenas alguns picos negativos são corrigidos., enquanto as amostras do PCR atrasadas, em sua maioria, continuam apresentando esse comportamento. Uma análise minuciosa da distribuição do número de bytes que compõem cada tipo de quadro do vídeo (I, P, e B) e dos critérios para o descarte de pacotes, pode explicar tal desempenho. Para o vídeo de trabalho, os quadros $\mathrm{B}$ representam cerca de um terço dos bytes transmitidos pelos pacotes TS. Adicionalmente, são descartados um número aleatório 
de pacotes (entre 1 e 7 por pacote UDP) contendo informações de quadros B. Ou seja, o número efetivo de bytes descartados é reduzido aleatoriamente a cada iteração do algoritmo. Podem ocorrer, portanto, situações em que o número de bytes efetivamente descartados é pequeno. Como o modelo de temporização do MPEG-2 System baseia-se numa escala temporal relacionada aos bytes transmitidos e não aos quadros transmitidos, quando poucos bytes estão disponíveis para descarte o sincronismo das amostras do PCR é pouco influenciado pelo algoritmo.

Entretanto, o algoritmo não é invalidado por esse fato, pois em determinados picos negativos onde os critérios de projeto são atendidos, ou seja, o pacote TS é pertencente a um quadro B e ele está atrasado na linha de tempo determinada pelo PCR, o algoritmo corrige essa distorção e diminui a variação de atraso do PCR. Em um determinado vídeo comprimido em que os quadros B representem mais em termos de bytes o algoritmo apresentaria um melhor desempenho.

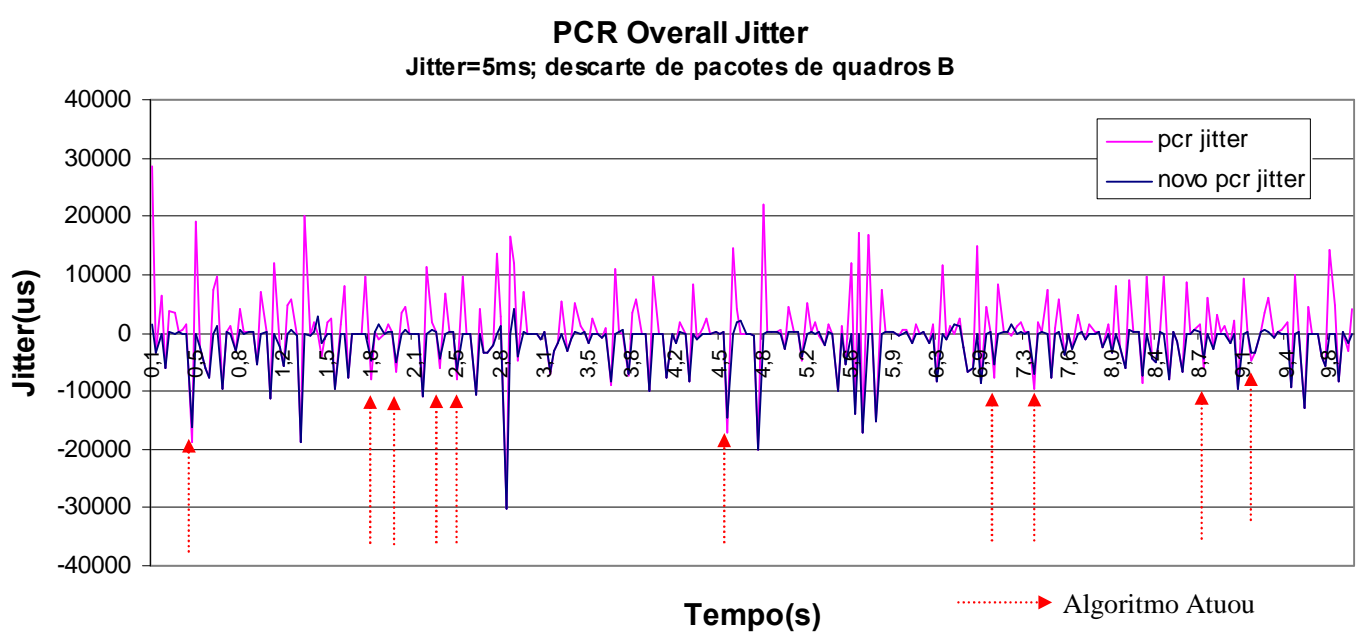

Figura 7.17 - Gráfico da variação de atraso das amostras do PCR para a variação de atraso na rede de $5 \mathrm{~ms}$, com a atuação do módulo de ressincronismo implementando o algoritmo de descarte de pacotes de quadros B.

Na figura 7.18 é apresentado um gráfico do comportamento do PSNR em função da variação de atraso na rede. Esse resultado indica que o PSNR sofreu grande influência da variação de atraso na rede. Essa influência, conforme antecipado pela seção 7.2.1, pode ser explicada pelo reordenamento de pacotes no 
módulo de controle da rede. No entanto, o método de descarte de pacotes de quadros B também tem sua parcela de influência nesse resultado, na medida em que, ao descartar pacotes, degrada-se também a qualidade objetiva do vídeo (PSNR).

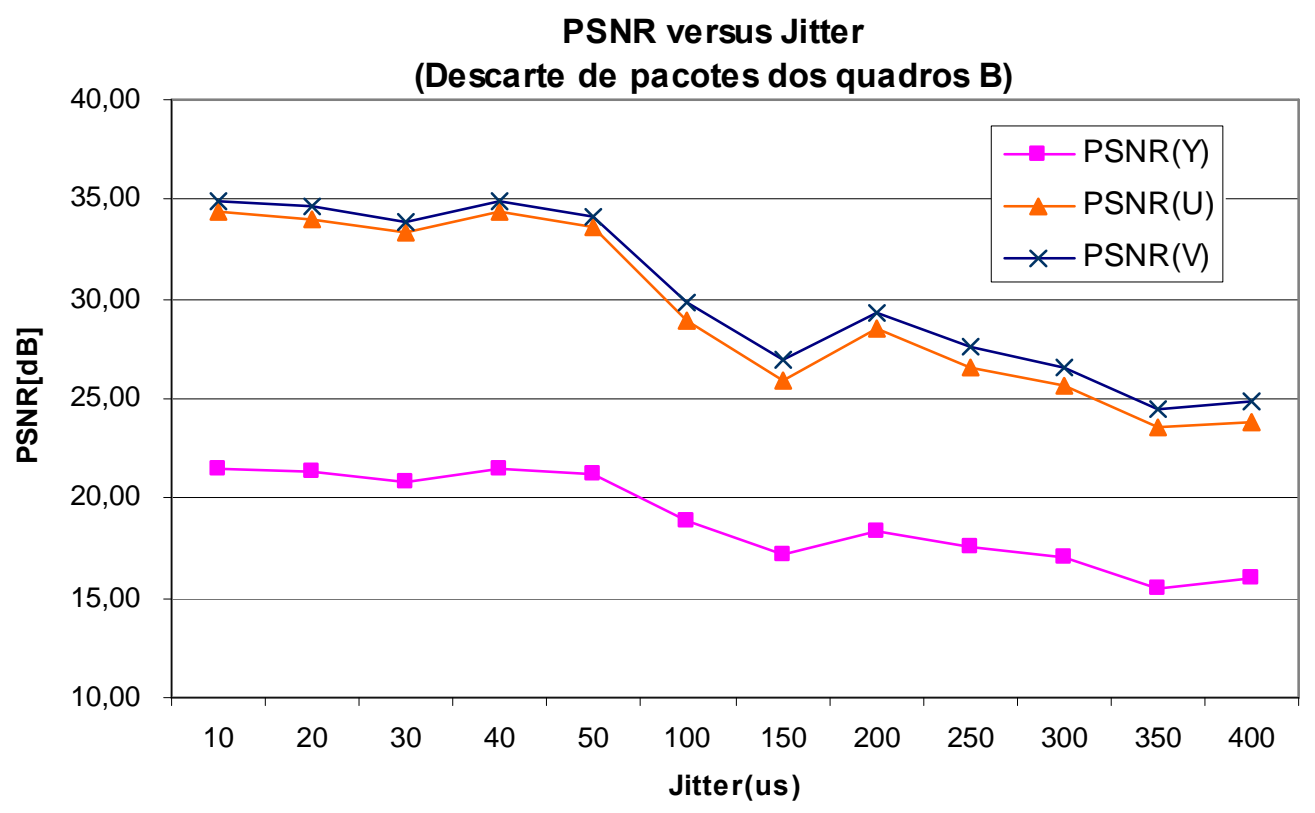

Figura 7.18 - Gráfico do PSNR em função da variação de atraso para o

Cenário 3.

\subsubsection{Cenário 4: Avaliação do ressincronismo implementado por meio dos métodos de inserção de pacotes nulos e de requantização de slices do vídeo comprimido}

A figura 7.19 apresenta o gráfico da variação de atraso nos PCR em função do tempo. Nesse gráfico, pode ser evidenciado que o desempenho do algoritmo de requantização de slices é melhor que o proposto para o cenário 3. Podem ser observados vários picos negativos em que a variação de atraso nos PCR é corrigida. A limitação apresentada pelo algoritmo de descarte de pacotes de quadros B não existe no algoritmo proposto para o cenário 4 , pois, independentemente do tipo de quadro (I, P e B), os slices podem ser requantizados e assim o sincronismo dos PCR corrigido.

Na figura 7.20, é apresentado o gráfico do PSNR em função da variação de atraso para o método de requantização de slices do vídeo comprimido. Como no 
cenário 3, os resultados indicam uma forte influência da variação de atraso na rede no PSNR.

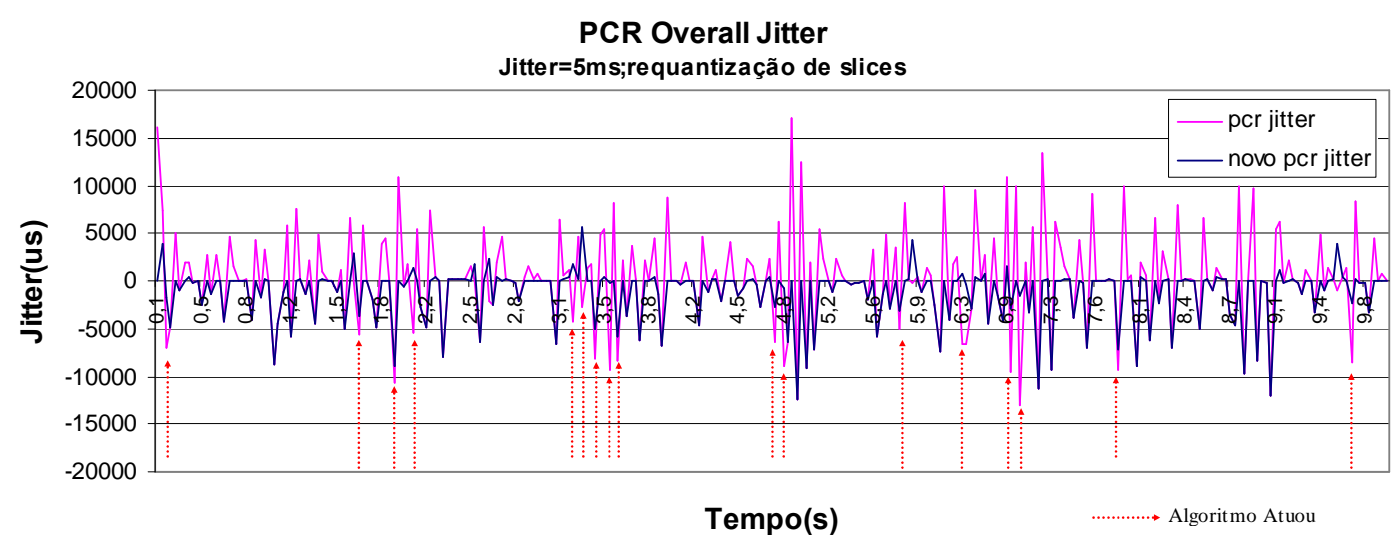

Figura 7.19 - Gráfico da variação de atraso das amostras do PCR para a variação de atraso na rede de $5 \mathrm{~ms}$, com a atuação do módulo de ressincronismo implementando o algoritmo de requantização de slices.

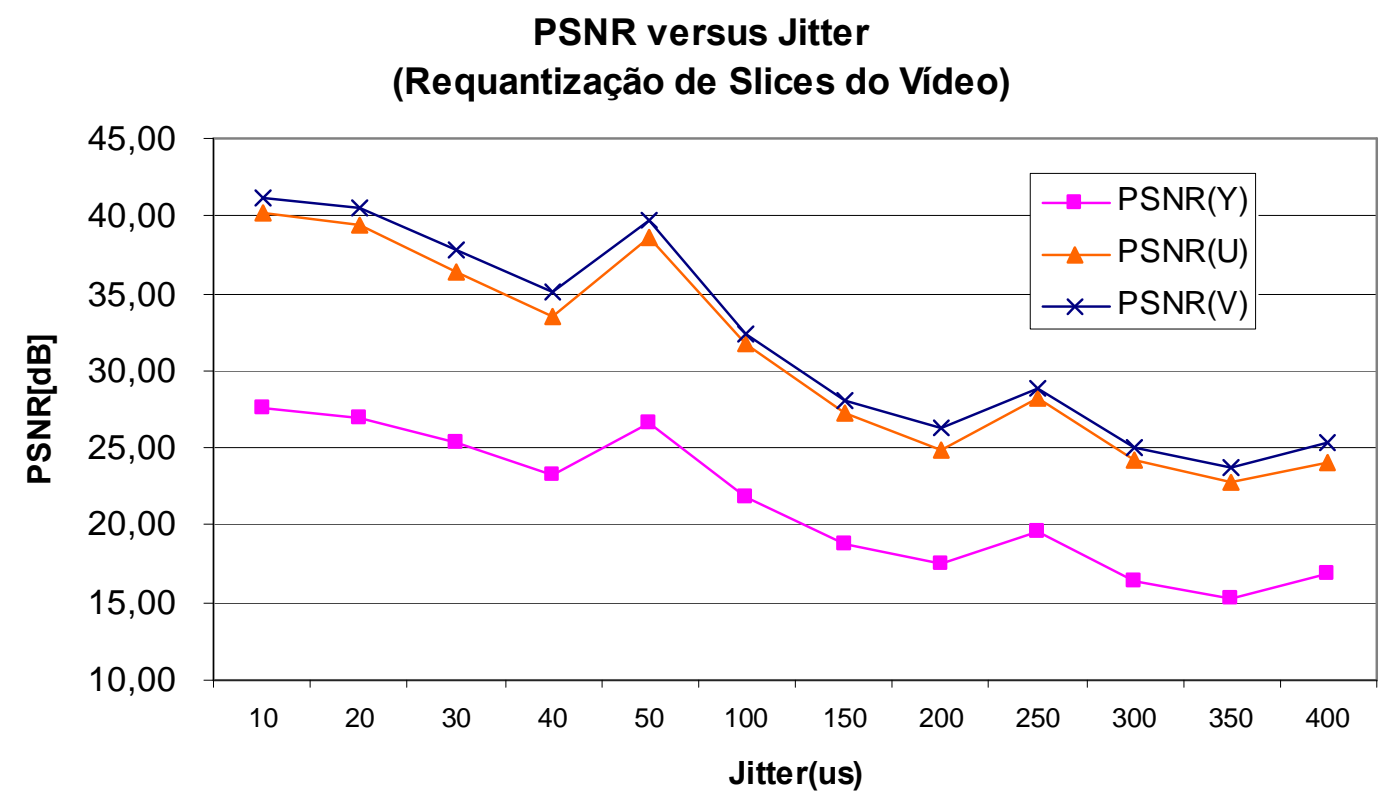

Figura 7.20 - Gráfico do PSNR em função da variação de atraso para o Cenário 4. 
Cenários de teste e resultados experimentais

\subsection{Análise dos Resultados Experimentais}

Os resultados obtidos para a variação de atraso das amostras do PCR indicam que os métodos de ressincronismo atuaram conforme suas especificações (capítulo 5 e 6) e conforme a expectativa inicial. $\mathrm{Na}$ análise dos resultados deve ser considerado, para o fluxo de vídeo utilizado no teste, que a aplicação de uma variação de atraso de 5,000ms na rede de distribuição tem como conseqüência um aumento da variação de atraso média nas amostras do PCR de $1,505 \mathrm{~ms}$ para 3,817ms.

Considerando os resultados obtidos para o cenário 2, pode ser verificado que o algoritmo de inserção de pacotes nulos reduziu a variação de atraso para as amostras de PCR adiantadas em termos absolutos de $3,657 \mathrm{~ms}$ para $0,130 \mathrm{~ms}$ em média. Já os dois outros métodos testados pelos cenários 3 e 4, utilizados para corrigir a variação de atraso para as amostras de PCR atrasadas, reduziram a variação de atraso em termos absolutos de 4,641ms para 4,323ms em média, para o cenário 3 , e de 3,628ms para 2,714ms, para o cenário 4.

Consolidando os resultados tanto para as amostras do PCR atrasadas como para as amostras adiantadas obtêm-se os seguintes valores de redução da variação de atraso das amostras do PCR:

- Métodos de inserção de pacotes nulos e descarte de pacotes de quadros B em conjunto obtiveram uma redução de $48,72 \%$ na variação de atraso média, sendo em termos absolutos uma redução de 4,369ms para 2,129ms;

- Métodos de inserção de pacotes nulos e requantização em conjunto obtiveram uma redução de 43,19\% na variação de atraso média, sendo em termos absolutos uma redução de $3,380 \mathrm{~ms}$ para $1,460 \mathrm{~ms}$.

Dessa forma, verifica-se que os métodos em conjunto são eficientes na manutenção do sincronismo das amostras de PCR, pois reduziram a variação de atraso nas amostras do PCR para os níveis anteriores (sem adição de variação de atraso na rede, ou seja, em torno de 1,500 ms). Observa-se assim que o módulo de ressincronismo pode garantir o sincronismo do fluxo de transporte. Essa garantia permite o estabelecimento de taxas do fluxo de transporte adequadas entre duas 
Cenários de teste e resultados experimentais

amostras do PCR, de maneira a garantir também o correto preenchimento dos buffers do receptor e, conseqüentemente, a correta recepção dos fluxos elementares.

Com relação aos resultados da avaliação da influência dos parâmetros da rede para a qualidade objetiva do vídeo recebido, pode ser feita uma crítica dos dados obtidos em cada um dos métodos de ressincronização propostos. Os métodos utilizados nos cenários 2,3 e 4 tiveram comportamentos diferentes. $\mathrm{O}$ método de inserção de pacotes nulos apresentou maior imunidade do PSNR às variações de atraso da rede. Os outros dois métodos apresentaram um desempenho inferior, em termos da métrica de qualidade de vídeo, a esse método de inserção de pacotes nulos. Entretanto, cada um deles deve ser avaliado considerando as suas particularidades.

O método de requantização de slices do vídeo teve um desempenho melhor que o método de descarte de pacotes de quadros $\mathrm{B}$, como pode ser evidenciado por meio dos gráficos do PSNR para os cenários 3 e 4.

Essa diferença de desempenho pode ser explicada pela implementação do método de descarte de pacotes de quadros B. Uma das premissas desse método foi considerar que a degradação da qualidade do vídeo na ocorrência de descartes de pacotes TS de quadros B seria pequena, o que não se confirmou. Quando se descarta um pacote TS de um quadro $B$, descartam-se todas as informações contidas no pacote, ou seja, é possível que sejam descartados vetores de movimento, macroblocos e slices inteiros de quadros B. No decorrer dos testes do cenário 3, a percepção visual do vídeo recebido pelo módulo de recepção já indicava que alguns artefatos do vídeo estavam sendo perdidos, pois era visível a degradação de algumas áreas do quadro. No método de requantização, por sua vez, alterou-se a resolução dos coeficientes da DCT sem, no entanto, descartar informação dos vetores de movimento, cabeçalhos, etc.

Nota-se, entretanto, uma degradação do PSNR em ambos os métodos comparando-se os resultados dos cenários 3 e 4 com o cenário 2. Ou seja, a atuação tanto do método de descarte de pacotes de quadro $\mathrm{B}$ quanto do método de requantização diminuiu o PSNR. Esse resultado é, até certo ponto, esperado, pois esses métodos atuam diretamente no vídeo comprimido.

Conclui-se que a influência da variação de atraso na rede de distribuição é extremamente importante para determinar a qualidade objetiva do vídeo recebido. 
Métodos que realimentem informações do módulo de avaliação de qualidade de vídeo e do PCRPROBE para o módulo de ressincronismo poderiam minimizar tais efeitos, pois o descarte de pacotes e a requantização poderiam se adaptar à qualidade final obtida e ao sincronismo das amostras do PCR, de forma a determinar uma qualidade ótima no vídeo recebido. Trabalhos futuros poderão tratar tais problemas de forma a tornar o framework proposto mais eficiente. 


\section{CONCLUSÕES}

Nesta dissertação, foram discutidos aspectos fundamentais para o sincronismo de programas MPEG2 em fluxos de transporte. Foram descritos mecanismos de multiplexação, tais como os Fluxos de Transporte e de Programa do MPEG2 System, e também métodos para ressincronizar esses fluxos. A partir dessa teoria básica de ressincronismo foi proposto um framework para avaliar e testar a influência dos parâmetros de QoS de redes de distribuição de conteúdo na exibição de fluxos elementares e no sincronismo em terminais de recepção móvel.

O framework proposto é constituído de seis módulos principais, descritos extensamente nos capítulos 5 e 6: Módulo de Transmissão, Módulo de Controle da Rede, Módulo de Ressincronismo, Módulo de Avaliação de Qualidade, Módulo de Monitoração das Características das Amostras do PCR (PCRPROBE) e Módulo de Recepção. Por meio da implementação desses módulos, alguns testes foram efetuados para avaliar a influência de atrasos, perda de pacotes, variação de atrasos e duplicação de pacotes na exibição de vídeo no Módulo de Recepção, e verificar também o desempenho do framework na ressincronização de fluxos de transporte MPEG2.

Os seguintes cenários foram propostos para testar o framework:

- Cenário 1: Influência dos parâmetros de QoS na qualidade objetiva do vídeo recebido;

- Cenário 2: Avaliação isolada do método de inserção de pacotes nulos;

- Cenário 3: Avaliação do ressincronismo implementado por meio dos métodos de inserção de pacotes nulos e de descarte de pacotes dos quadros B;

- Cenário 4: Avaliação do ressincronismo implementado por meio dos métodos de inserção de pacotes nulos e de requantização de slices do vídeo comprimido.

A investigação acerca do desempenho do framework na ressincronização de fluxos de transporte MPEG2 mostrou que ele atende ao propósito para o qual foi especificado. Ou seja, por meio dos algoritmos de inserção de pacotes nulos, descarte de pacotes de quadros $\mathrm{B}$ e da requantização de slices descritos no capítulo 6 foi possível corrigir a variação de atraso das amostras do PCR decorrente da variação de 
atraso da rede de distribuição. Os resultados experimentais, para o fluxo de vídeo utilizado no teste, indicam que a variação de atraso das amostras do PCR, após a aplicação desses algoritmos, voltou aos níveis medidos para uma transmissão sem variação de atraso na rede.

O método de inserção de pacotes nulos teve o melhor desempenho dentre os três métodos propostos devido ao seu caráter determinístico. Nesse método é calculado exatamente o número de pacotes nulos necessários para que a amostra do PCR que estiver adiantada seja corrigida e passe a refletir o valor indicado na amostra do PCR (valor do PCR em microssegundos).

Os dois outros métodos utilizam a variação de atraso calculada para cada pacote na definição de como corrigir o sincronismo de amostras atrasadas do PCR. O método de descarte de pacotes de quadros calcula o número de pacotes que devem ser descartados para que a próxima amostra do PCR não chegue atrasada. O método de requantização de slices, por sua vez, efetua a requantização de slices contidos em pacotes TS recebidos entre dois PCRs consecutivos sempre que um determinado pacote estiver adiantado. Entretanto, ambos os métodos tentam prever o comportamento da variação de atraso das amostras do PCR a partir da variação de atraso dos pacotes recebidos. Como a variação de atraso na rede não é previsível, as estimativas feitas por pacote podem ser ligeiramente diferentes da variação de atraso efetivamente ocorrida nas amostras do PCR.

Além disso, na especificação do método de requantização de slices foi definido um limiar para a atuação do algoritmo. Ou seja, o algoritmo somente atua quando a variação de atraso de um determinado pacote é maior que $10 \mathrm{~ms}$. Esse limiar foi especificado de forma a viabilizar sua utilização no módulo de ressincronismo, pois seria inviável requantizar todos os bytes do vídeo recebido, devido ao custo computacional dessa operação e ao atraso que seria inserido na transmissão decorrente da requantização. Todavia, um efeito colateral pôde ser verificado, algumas amostras do PCR não são corrigidas e assim o desempenho global do método de requantização diminui. Apesar disso, o desempenho atingido ainda foi razoável, sendo a redução da variação de atraso para amostras atrasadas do PCR de 25\% para o vídeo de teste e nas condições do cenário de testes 4. 
O método de descarte de pacotes de quadros $B$, por sua vez, não tem restrições de processamento, entretanto, seu desempenho foi prejudicado devido a configuração do vídeo utilizado nos testes e o mecanismo de descarte aleatório de pacotes. O percentual de bytes de quadros B efetivamente descartados pode ser pequeno em relação a demanda de redução de bytes para que a amostra do PCR não chegue atrasada. Isso pode ser verificado nos resultados experimentais, na medida em que o desempenho na redução dos picos negativos do gráfico de variação de atraso das amostras do PCR foi reduzido em somente 6,25\%.

Além dos resultados para o desempenho dos métodos de ressincronização, os testes efetuados indicam que a perda de pacotes, a duplicação de pacotes e a variação de atraso influenciam significativamente a qualidade da exibição de vídeos transportados por fluxos de transporte. A degradação da qualidade objetiva do vídeo medida pelo PSNR (Peak Signal to Noise Ratio) é significativa, à medida que esses parâmetros são alterados. Para a perda de pacotes e duplicação de pacotes, valores de $10 \%$ de perda ou duplicação de pacotes determinam uma qualidade ruim na exibição. Já para a variação de atraso, os resultados indicaram que valores acima de 200us apresentam qualidade ruim.

Quando o módulo de ressincronismo foi utilizado para compensar a variação de atraso inserida pelo módulo de controle da rede, observou-se uma melhoria para o método de inserção de pacotes nulos, onde o nível de qualidade ótimo (acima de $33 \mathrm{~dB}$ ) é mantido até $100 \mu \mathrm{s}$ e a qualidade torna-se ruim apenas para valores de variação de atraso superiores a $200 \mu \mathrm{s}$. Para os outros métodos, o método de requantização determinou melhores valores para a métrica de qualidade objetiva que os apresentados para o método de descarte de pacotes de quadros B.

Com esses resultados, consolidam-se os benefícios obtidos com a proposta do framework. Esses benefícios são:

- A capacidade do framework atuar no fluxo de transporte, ressincronizando tanto para o caso de amostras do PCR atrasadas quanto de amostras adiantadas, enquanto vários dos métodos apresentados no capítulo 4 atuam somente em um desses casos;

- A correção do sincronismo pelo framework sem a utilização de métodos complexos como o recálculo de todas as amostras de PCR ou a compensação das 
variações de atraso (seção 4.3.1), que necessitam de implementações em hardware;

- A implementação do framework feita totalmente em software, apresentando assim custos menores, se comparados a uma implementação em hardware;

- A capacidade do framework avaliar e testar as diversas condições da rede de distribuição: atrasos, variações de atraso, perda de pacotes, etc;

- A atuação do sistema de ressincronização proposto em diversos pontos de uma rede de distribuição e no próprio receptor.

Para trabalhos futuros, otimizações na implementação do método de requantização podem ser propostas de forma a possibilitar sua utilização para todos os pacotes atrasados. Para diminuir o tempo de processamento do método de requantização, recomenda-se sua implementação em hardware ao invés da implementação em software utilizada nos testes.

A influência do descarte de pacotes de quadros B deve ser melhor investigada para determinar se a degradação da qualidade do vídeo, quando da utilização do método de descarte de pacotes de quadros $\mathrm{B}$, é resultante de sua atuação.

É importante ressaltar também que a pesquisa científica é marcada pela complexidade de fatores envolvidos, principalmente quando simulações e testes são utilizados. Além disso, a experimentação faz parte do processo investigativo, sendo com esse espírito que se recomenda a utilização de novas ferramentas para continuar a pesquisa iniciada nesta dissertação. Em trabalhos futuros, para evitar os efeitos indesejados observados em decorrência do reordenamento de pacotes, provocado pelo módulo de controle da rede, sugere-se a utilização de equipamentos disponíveis no mercado dedicados a esse fim, ou a utilização de infra-estrutura de rede comercial, onde os testes descritos nesta dissertação possam ser repetidos em ambiente real ao invés de em ambiente de laboratório. 


\section{REFERÊNCIAS BIBLIOGRÁFICAS}

_. "Timestamping Schemes for MPEG2 Systems Layer and their Effect on Receiver Clock Recovery”. IEEE Transactions on Multimedia, Vol. 1, No. 3, Set. 1999.

DVB-T: New Operative Modes for Digital Terrestrial TV. In: BROADCAST ASIA INTERNATIONAL CONFERENCE, 2002.

ADVANCED TELEVISION SYSTEMS COMMITTEE. ATSC A/53C: ATSC Digital Television Standard A/53C with Amendment No. 1. Washington, 2004.

AEHURI, P. K. et al. Objective Quality Analysis of MPEG1, MPEG2 and Windows Media Video. IEEE, 2004.

ASSOCIATION OF RADIO INDUSTRIES AND BUSINESSES. ARIB STD-10: Service Information for Digital Broadcasting System, version 3.2. Japão, 2001.

ASSOCIATION OF RADIO INDUSTRIES AND BUSINESSES. ARIB STD-B31: Transmission System For Digital Terrestrial Television Broadcasting, version 1.2. Japão, 2002.

BENOIT, H. Digital Television. MPEG1, MPEG2 and principles of the DVB System. Londres: Arnold Publishing, 1997.

BERTELLA, et al. Mobile DVB-T Reception: Quality of Streaming over IP of Audiovisual Services. In: INTERNATIONAL BROADCASTING CONVENTION, 2002, Amsterdã.

BOUAZIZI, I. Estimation of Packet Loss Effects on Video Quality. IEEE, 2004. BROOKS, M. P.; MATTEI, A. DVB-T Reception Issues in a Mobile Environment. In: INTERNATIONAL BROADCASTING CONVENTION, 2002, Amsterdã. 
BUNGUM, O. W. Transmultiplexing, Transcontrol and Transscrambling of MPEG2/DVB Signal. In: INTERNATIONAL BROADCASTING CONVENTION, 1996, Amsterdã. Conference Publication no. 428, September 1996.

CITTA, R.; SGRIGNOLI, G. ATSC Transmission System: VSB Tutorial. In: ITVS SYMPOSIUM, 1997, Montreux.

CLAYPOOL, M.; TANNER, J. The Effects of Jitter on the Perceptual Quality of Vídeo. ACM Multimedia, 1999.

COMMUNICATIONS COMMISSION ON INFORMATION AND RADIO. CCIR 500-3: Method for the Subjective Assessment of the Quality of Television Pictures. Recommendations and Reports of the CCIR, 1986, XVth Plenary Assembly, Volume XI, Part 1.

DU, D. H. C. et al. PCR-Assist CBR for Delivering Pre-Recorded MPEG2 Transport Streams. In: IEEE INTERNATIONAL CONFERENCE ON MULTIMEDIA COMPUTING AND SYSTEMS, 1997. Proceedings, p. 646-647, Jun. 1997.

EUROPEAN TELECOMMUNICATIONS STANDARDS INSTITUTE. EN 300 744: Framing structure, channel coding and modulation for digital terrestrial television, version 1.5.1. França, 2004.

EUROPEAN TELECOMMUNICATIONS STANDARDS INSTITUTE. ETS 300 468: Digital broadcasting systems for television, sound and data services; Specification for Service Information (SI) in Digital Video Broadcasting (DVB) Systems, version 1.6.1. França, 2004.

FAIRHURST, G. Ultra Lightweigth Encapsulation (ULE) for Transmission of IP datagrams over MPEG2/DVB Networks. Internet Draft, Mar. 2004. 
FARIA, G. The Digital Video Broadcasting System. França: ITIS, 2000, 13p. (Relatório técnico).

FERNÁNDEZ, et al. Single Frequency Networks for Digital Vídeo Broadcasting. Espanha: Retevision S/A, Engineering R\&D, 2000. Disponível em: <http://www.broadcastpapers.com/tvtran/RetevisionSFNforDVB04.htm>. Acesso em: 30 jan. 2006.

GUTIÉRREZ, A. D. Flujos de Programa y de Transporte - MPEG2 Aplicácion a DVB. Madrid: Universidad Politécnica de Madrid, 2001. (Relatório técnico).

HASKELL, B. G.; PURI, A.; NETRAVALLI, A. N. Digital Video: An Introduction to MPEG2. Nova Iorque: Chapman \& Hall, 1997.

HAYKIN, S. Communication Systems. EUA: John Wiley \& Sons, 1994.

HENG, B. A. Multiple Description Video Coding Through Adaptive Segmentation, 2004, f. Dissertação (Doutorado). MIT, Jun. 2004.

INTERNATIONAL STANDARDIZATION ORGANIZATION. ISO 13818-1: Recommendation H.222.0 ISO/IEC 13818-1, Information Technology - Generic Coding of Moving Pictures and Associated Audio: Systems. November, 1994.

INTERNATIONAL STANDARDIZATION ORGANIZATION. ISO 13818-3: Recommendation H.262.0 ISO/IEC 13818-3, Information Technology - Generic Coding of Moving Pictures and Associated Audio: Video. Novembro, 1994.

INTERNATIONAL STANDARDIZATION ORGANIZATION. TEST MODEL 5: ISO/IEC JTC1/SC29/WG11/N0400, MPEG93/457. Abril, 1993.

KAXE, B. Synchronisation of MPEG2 based Digital TV Services over IP Networks, 2000, f. Dissertação (Mestrado), Telia Research AB, Jan. 2000. 
MEHAOUA, A.; BOUTABA, R. The Impacts of Errors and Delays on the Performance of MPEG2 Video Communications. In: INTERNATIONAL CONFERENCE ON ACOUSTICS, SPEECH AND SIGNAL PROCESSING, 1999, Phoenix.

NOKES, C.; MITCHELL, J. Potential Benefits of Hierarchical Modes of the DVB-T Specification. In: IEE COLLOQUIUM DIGEST 99/72, 1999, Londres.

NORO, R. and HUSBAUX, J. P., "Improving Clock Synchronization for MPEG2 Services over ATM Networks". Laussane: Swiss Federal Institute of Technology, 1997 (Relatório técnico).

NORO, R. et al. Clock Synchronization of MPEG2 Services over Packet Networks. J.C. Telecommunications Systems Journal, Baltzer Science Publishers, Vol.11, Nos. 1-2, p. 3-16, Mar. 1999.

NORO, R. Synchronization over Packet-Switching Networks: Theory and Applications, 2000, f, Dissertação (Doutorado), École Polytechnique Fédérale de Lausanne, 2000.

PINSON, M.; WOLF, S. A New Standardized Method for Objectively Measuring Video Quality. IEEE Transactions on Broadcasting, vol. 50, no. 3, Set. 2004.

PRZYBYLSKI, M.; BELTER, B.; BINCZEWSKI, A. Shall we worry about Packet Reordering? Computational Methods in Science and Technology, p.141- 146, vol. 11(2), 2005.

REIBMAN, A. R.; VAISHAMPAYAN, V. A.; SERMADEVI, Y. Quality Monitoring of Video over a Packet Network. IEEE Transactions on Multimedia, Vol. 6, No. 2, Abril 2004. 
SINGH, N. Performance Analysis for Objective Methods of Video Quality Assessment. TechOnline Publications, Texas Instruments Audio and Video/Imaging Series, Oct. 2005. Disponível em <http://www.techonline.com/community/ tech_group/38742>. Acesso em: 30 jan. 2006.

SPARANO, D. What exactly is 8-VSB anyway? Harris Broadcast, 1997. Disponível em: < http://www.broadcastpapers.com/tvtran/Harris8VSB.pdf>. Acesso em: 30 jan. 2006.

SU, W.; AKYILDIZ, I. F. The jitter time-stamp approach for Clock Recovery of Real-time Variable Bit-Rate Traffic. IEEE/ACM Transactions on Networking, Vol. 9, No. 6, p.746-755, Dez. 2001.

TAKAHASHI, et al. MPEG2 Multi-Program Transport Stream Transcoder. In: IEEE INTERNATIONAL CONFERENCE ON MULTIMEDIA AND EXPO, IEEE Computer Society, 2001.

TEKTRONICS. PCR Measurements. Disponível em: <http://www.tek.com/Measurement/App_Notes/25_14617/eng/25W_14617_1.pdf>. Acesso em: 15 maio 2006.

TEKTRONIX. A Layman's Guide to PCR Measurements: Technical Brief. Disponível em: <http://broadcastpapers.com/testmeasurement/ TektronixLaymansPCR01.htm>. Acesso em: 30 jan. 2006.

TRYFONAS, C. Video Transport over Packet-Switched Networks, 1999, $207 \mathrm{f}$. Dissertação (Doutorado em Engenharia de Computação), University of California Santa Cruz, 1999.

TRYFONAS, C.; VARMA, A. A Restamping Approach to Clock Recovery in MPEG2 Systems Layer. In: INTERNATIONAL CONFERENCE ON COMUNICATIONS, 1999, Vancouver. Proceedings of IEEE ICC, Junho, 1999. 
WU, et al. On end-to-end Transport Architecture MPEG-4 video streaming over the Internet. IEEE Transactions on Circuit and System for Video Technology, p. 923-941, vol. 10, no. 6, Set. 2000.

XIN, et al. Digital Video Transcoding. Procedings of IEEE, Vol. 93, No. 1, Jan. 2005 .

YU, B.; NAHRSTEDT, K. A Realtime Software Solution for Resynchronizing Filtered MPEG2 Transport Stream. In: IEEE INTERNATIONAL SYMPOSIUM ON MULTIMEDIA SOFTWARE ENGINEERING, 2002.

ZHU, D. et al, End-to-End Modeling and Simulation of MPEG2 Transport Streams over ATM Networks with Jitter. IEEE Transactions on Circuits and Systems for Vídeo Technology, Vol. 8, No. 1, Feb. 1998. 


\section{ANEXO I}

Código fonte da função RESYNC_LOOP, que controla a ressincronização dos pacotes que entram no módulo de ressincronismo.

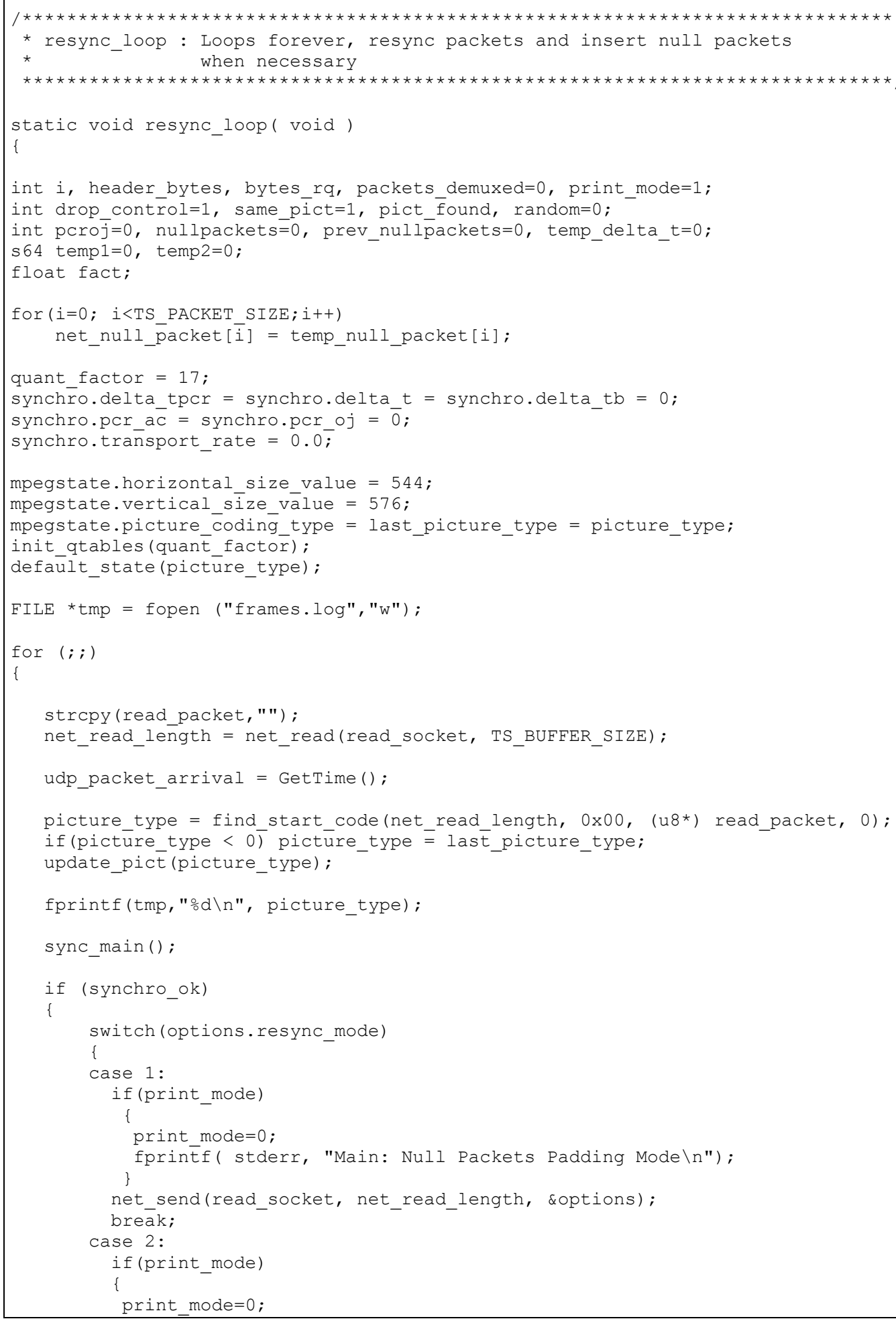




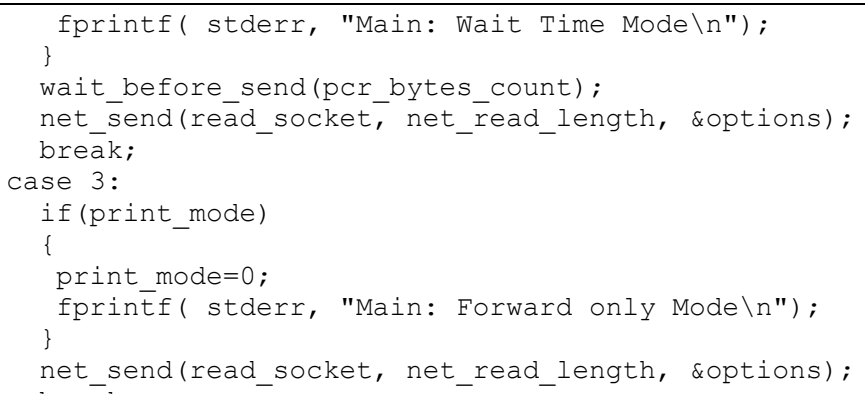




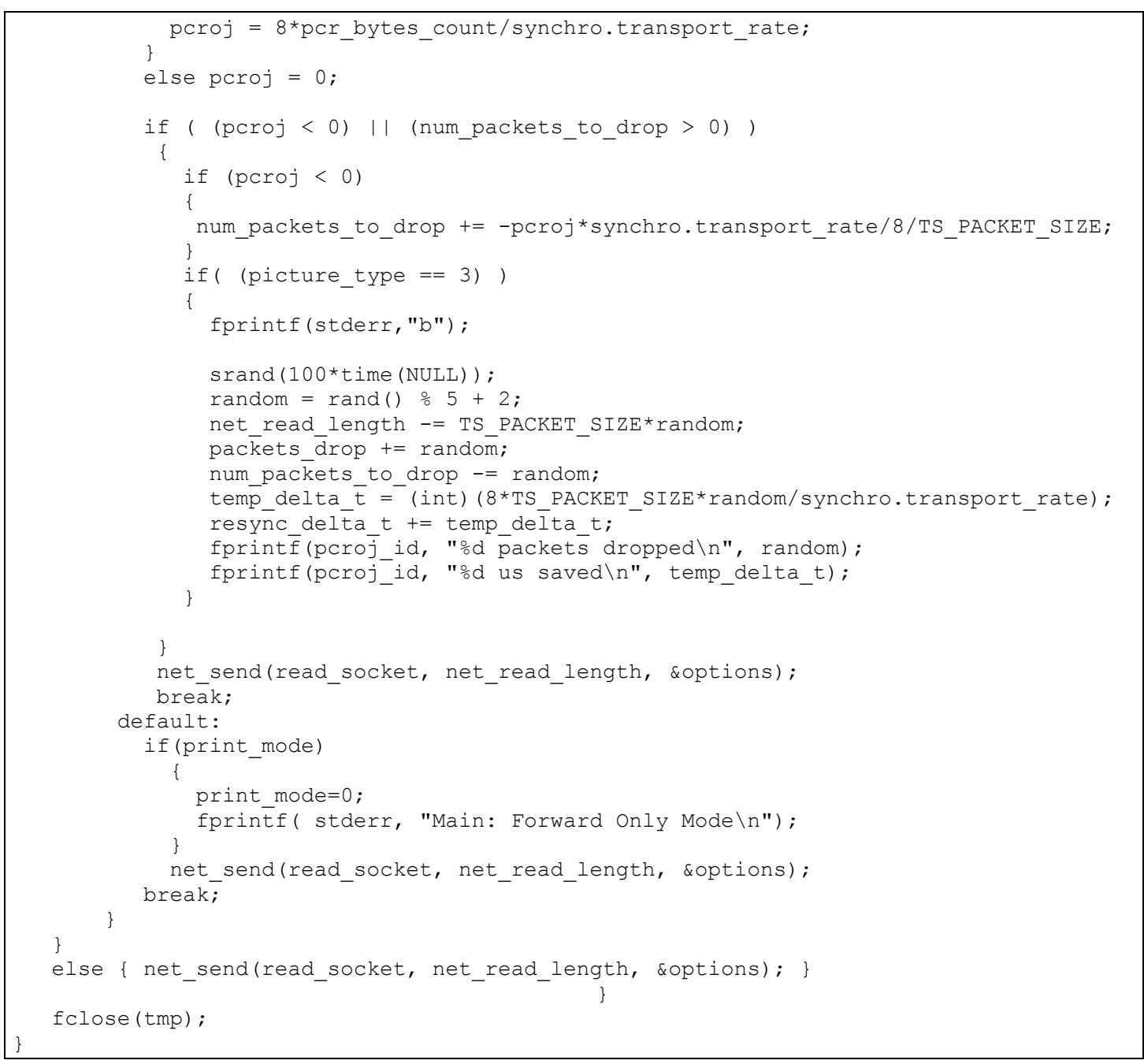

Código fonte da função SYNC_MAIN, que controla a atualização dos parâmetros de sincronismo do módulo de ressincronismo.

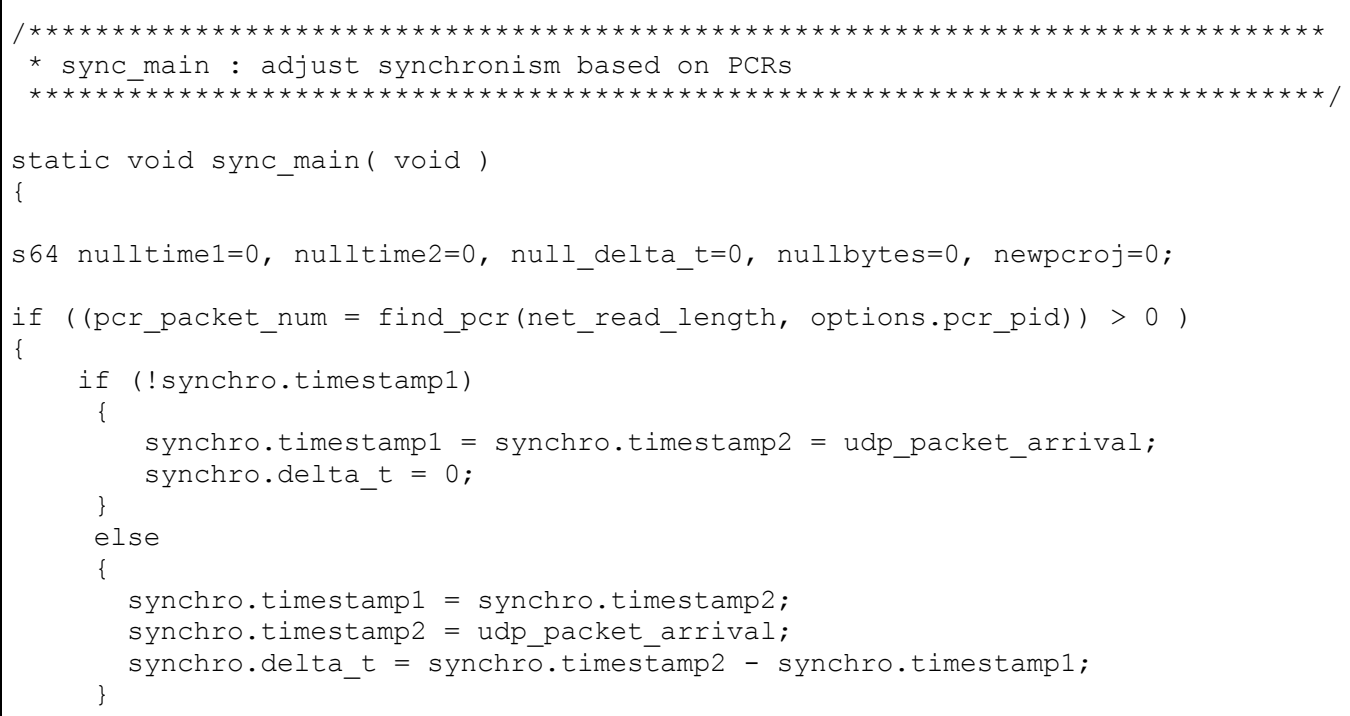




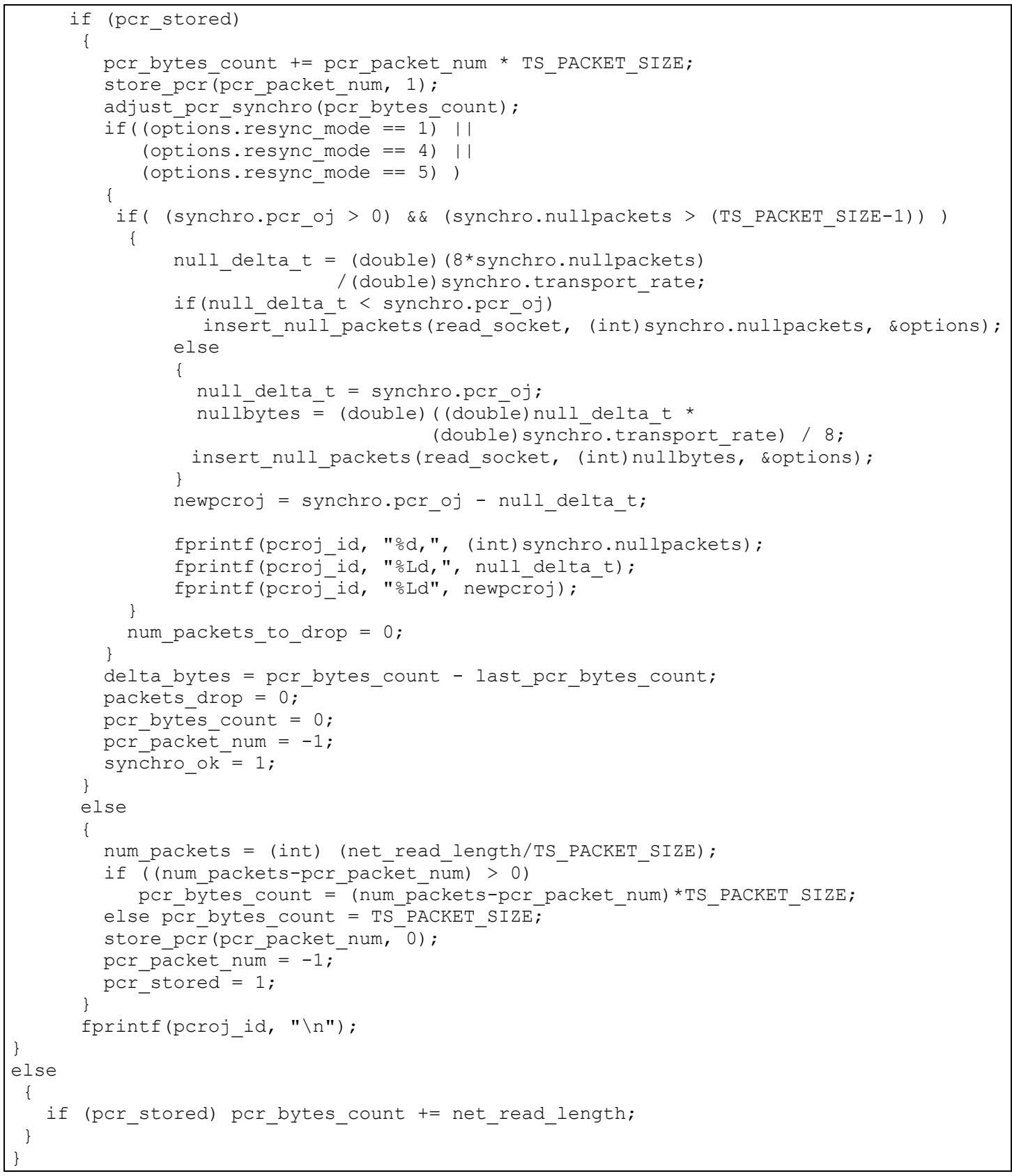

Código fonte da função M2V_REQ_LOOP, que implementa a requantização de slices.

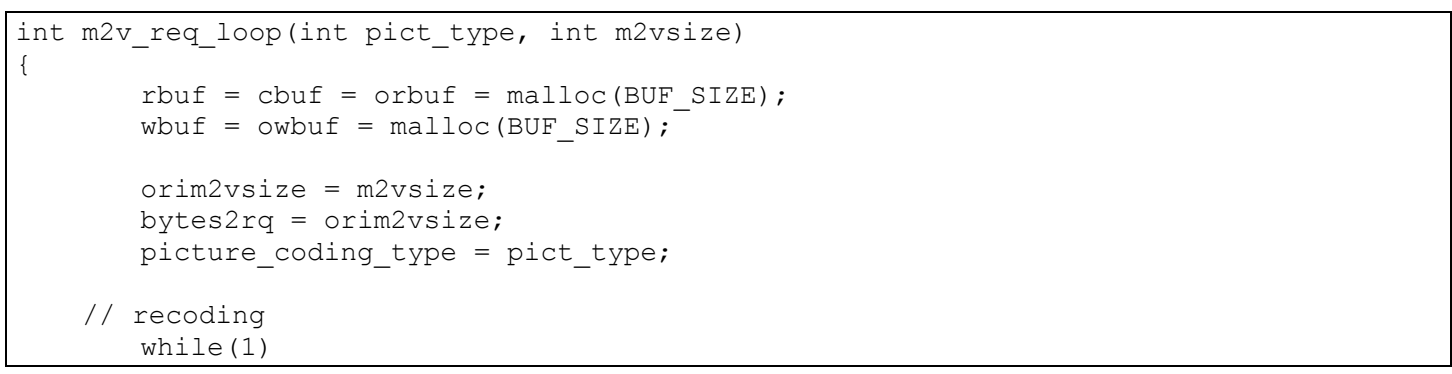




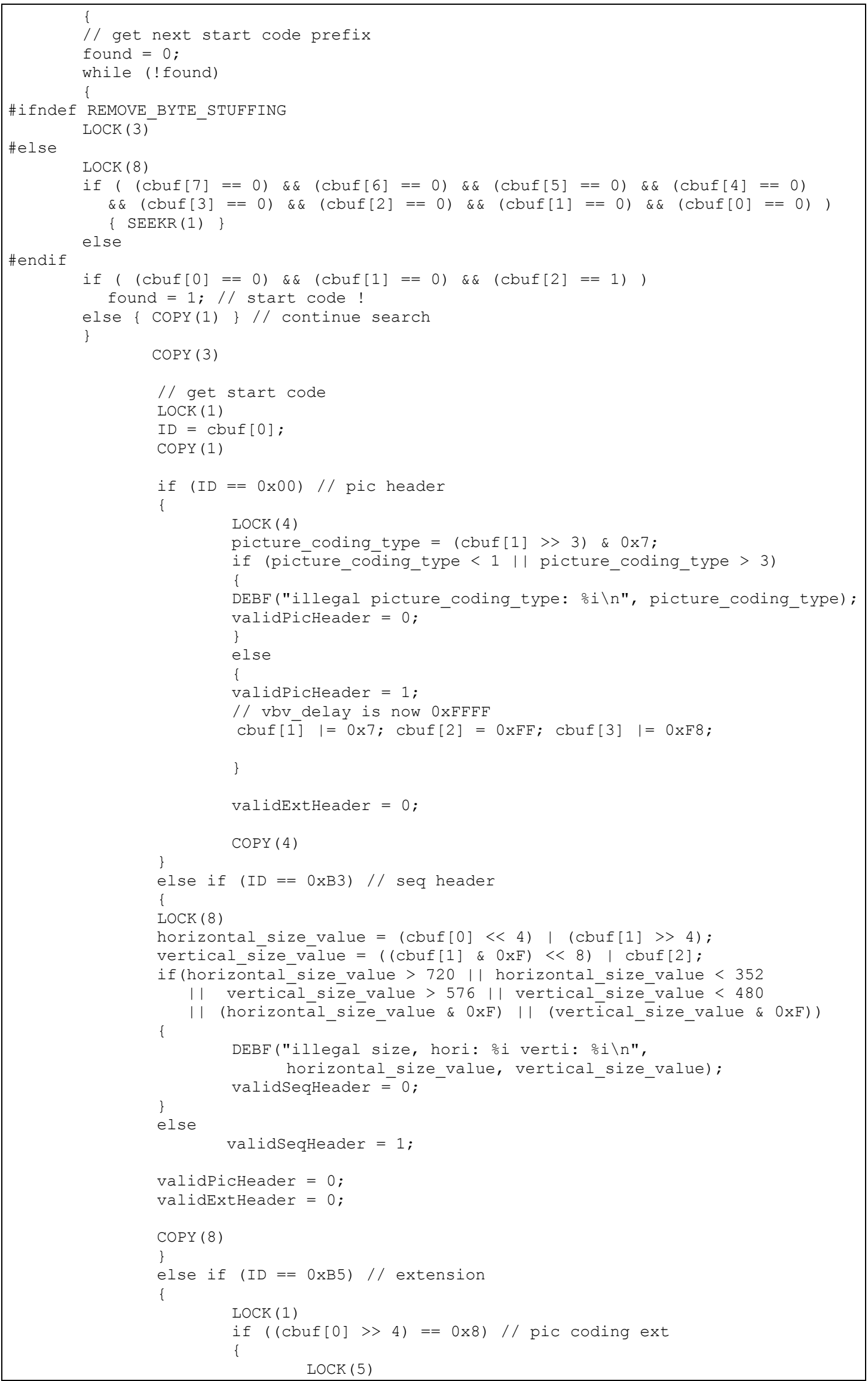




\begin{tabular}{|c|c|c|}
\hline $\begin{array}{l}\text { \#ifdef DEMO } \\
\text { \#endif }\end{array}$ & 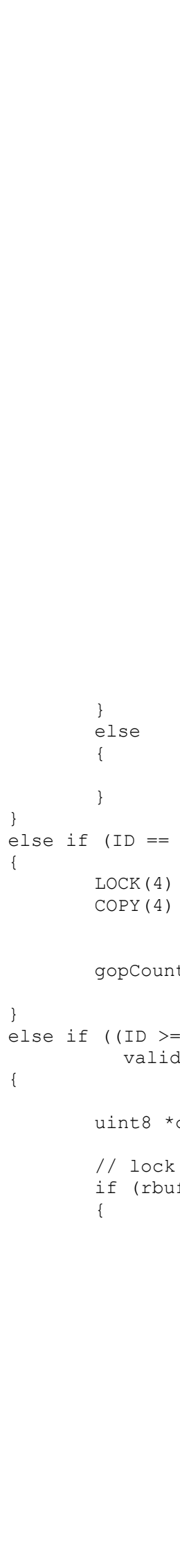 & 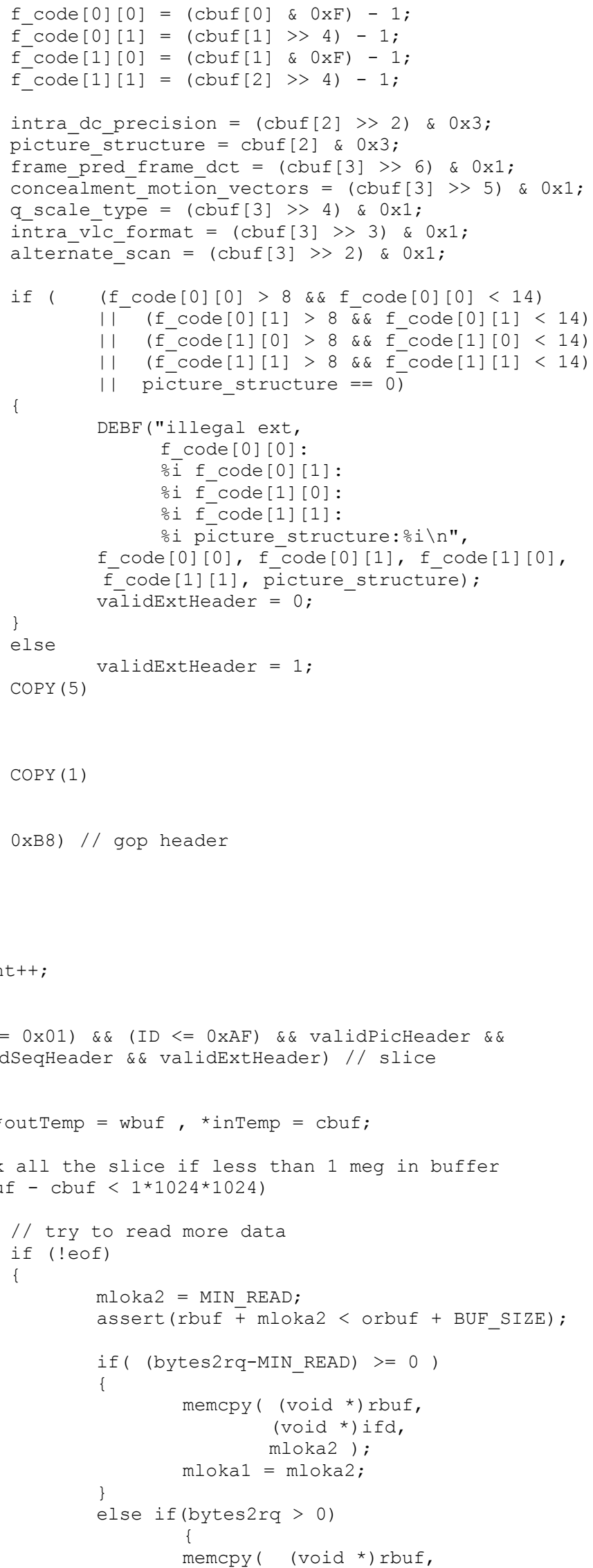 \\
\hline
\end{tabular}




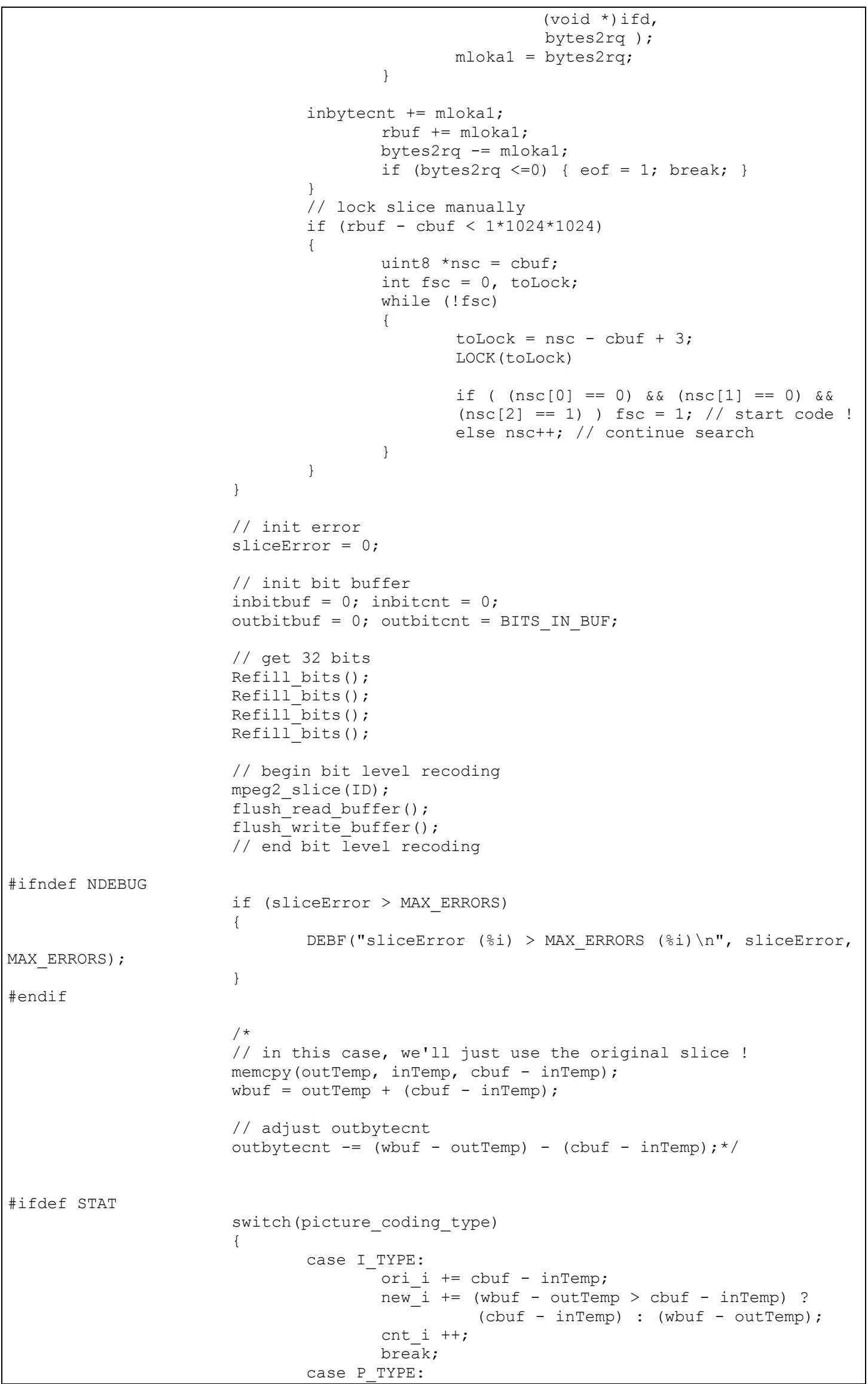


Anexos

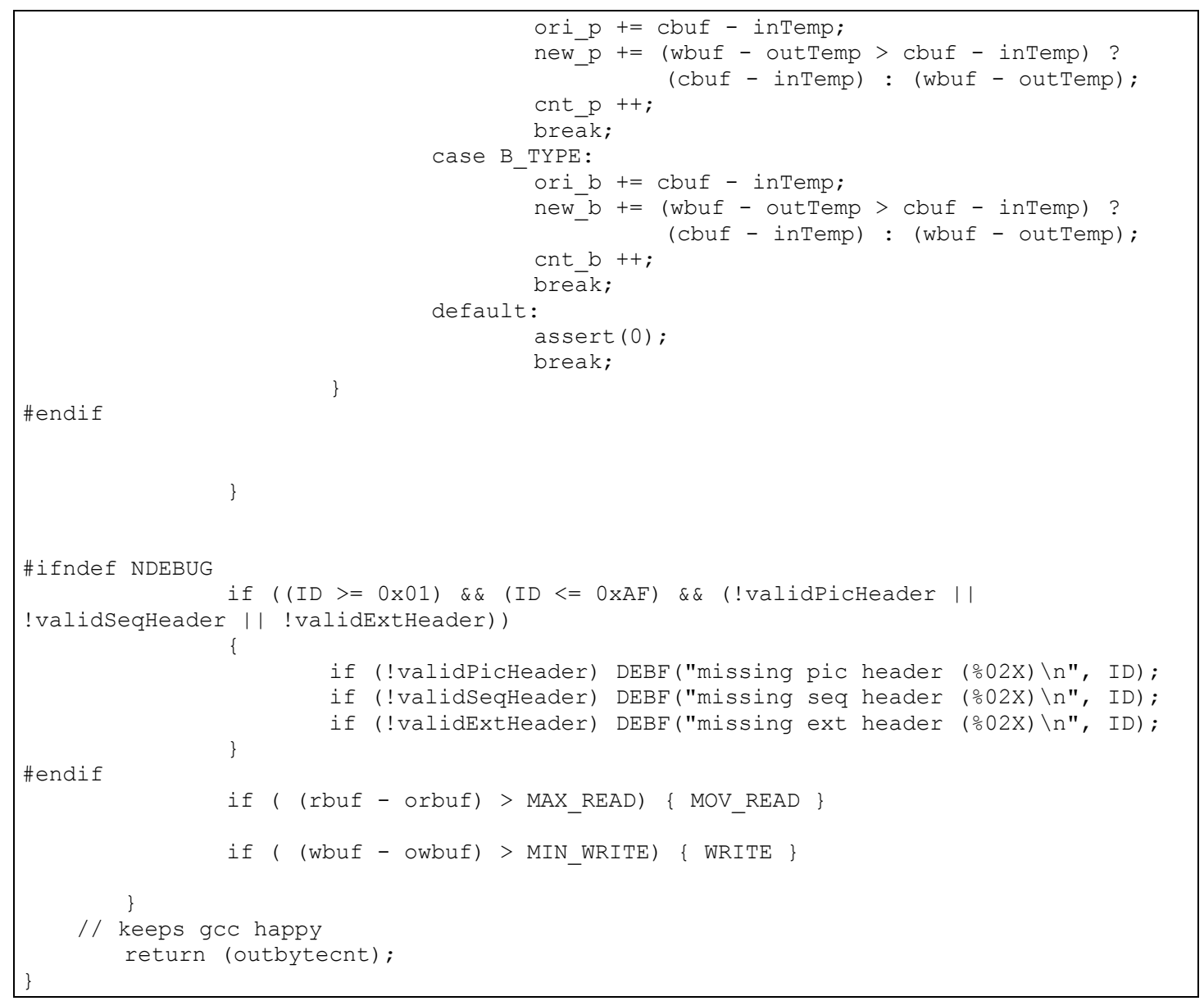

